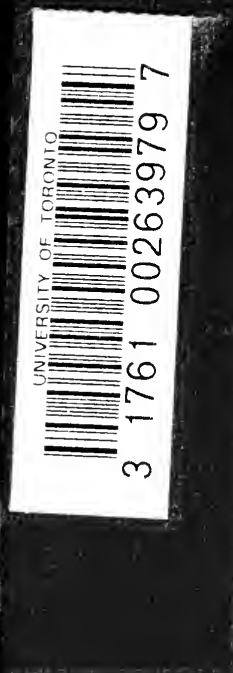





ST. AUGUSTINE AND HIS AGE 
All rights reserved 
$\frac{E}{\sqrt{5}}$

\section{SAINT AUGUSTINE}

A N D H IS A GE

BY

JOSEPH MCCABE

AUTHOR OF

'Peter abélard,' etc.

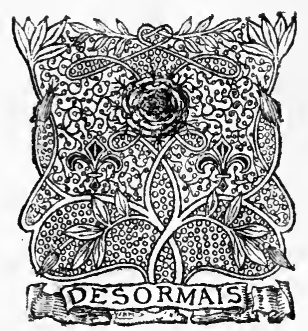

$\frac{59663}{24}$

\section{O N D O N}

DUCKWORTH and CO.

3 HENRIETTA STREET, W.C.

1902 


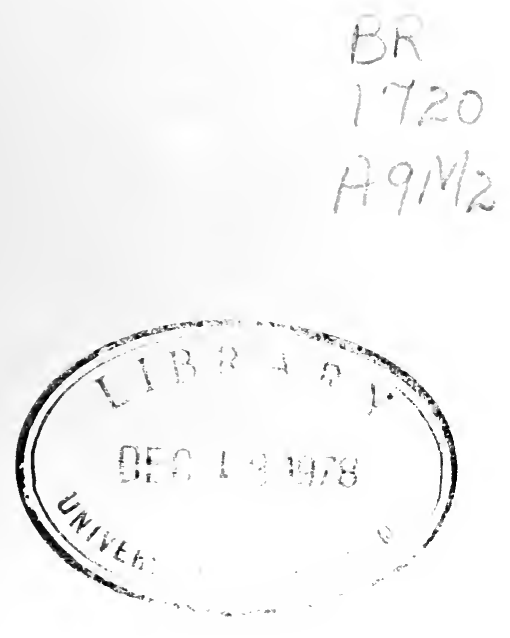

Edinburgh: T. and A. Constable, (late) Printers to Her Majesty 
SIR LESLIE STEPHEN, K.C.B.

IN GRATEFUL REGARD 



\section{PREFACE}

THIS work is an attempt to interpret the life of one of the most famous saints of the Christian Church by the light of psychology rather than by that of theology. There are many biographies of Saint Augustine - though our own literature is singularly poor in this respect-but all are constructed on the perverse type which is followed by Augustine himself in his seductive Confessions. When one brings to the story a saving tincture of Pelagianism, the distribution of light and shade seems to fall under more familiar laws. I have tried to exhibit the development of Augustine as an orderly mental and moral growth, and to present it in harmonious relation to the many other interesting figures and groups on the broad canvas of his age.

Fune 1902. 



\section{CONTENTS}

CHAP.

PAGF

I. LIFE IN ROMAN AFRICA. . . . . . . I

II. THE THIRD CITY OF THE EMPIRE • • • 22

III. MENTAL GROWTH . . . . . . . 44

IV. THE ETERNAL CITY . . . . . . . $\quad$. 69

V. THE OLD GODS AND THE NEW . . . . 87

VI. LIGHT FROM THE EAST . . . . . 114

VII. CONVERSION . . . . . . . . . I4I

VIII. RETURN TO AFRICA . . . . . . I66

IX. THE BISHOP OF HIPPO . . . . . . 193

X. THE DAILY TASK . . . . . . . 213

XI. AUGUSTINE AND THE DONATIST SCHISM . 243

XII. THE DYING OF PAGANISM • . . . . 278

XIII. ECHOES OF THE FALI, OF ROME. . . . 298 
CHAP.

XIV. THE WORKS OF AUGUSTINE . . . . 321

XV. AUGUSTINE AND PELAgIUS . . . • • $35 \mathrm{I}$

XVI. EPISODES OF HIS CLOOSING YEARS • . . $38 ;$

XVII. A SADDENED TERMINATION . . . . . 4 42

BIBLIOGRAPHY . • . . . . . . $43 \mathrm{I}$

INDEX • • • • • • • • $\quad \cdot 435$ 


\section{CHAPTER I}

\section{LIFE IN ROMAN AFRICA}

Aurelius Augustinus, known to all time as St. Augustine of Hippo, was born at Thagaste (now Souk-Arras, in Algeria) about the middle of the fourth century.

A glance at the map of Africa discovers a strip of territory of singular situation on its north-west border. Isolated from the rest of the continent by a range of lofty mountains that extends from Tunis to the Atlantic, its broad and fertile plains open to the breath of the great sea which was the heart of the world for so many ages, it seems to have been prepared by nature as the theatre of some thrilling national life. It seems as though it should have a natural immunity from the curse of Cham. Yet in the story of the nations that richly endowed territory has ever played the part of a dependency. Very early in history the Phœnicians wrested it from its native population, 
and built up the kingdom of Carthage on its fruitful soil. Rome made utter wreck of their work, and in its turn created a dependent African kingdom. In the fifth century a Teutonic race swept over it from the west; in the seventh the Arabs poured over it from the east. And the modern traveller finds himself wandering in a vast world of tombs, from which the last degenerate sons of the Prophet are emerging at the bidding of a new conqueror.

In the fourth century this strip of the African coast was one of the most important 'dioceses' of the Western Empire. Far away towards the crests of the Atlas a Roman legion protected it from the Libyan tribes of the mountains and the desert. The natural frontier formed by the steep southern face of the mountains was guarded by a long chain of forts and signal-towers. The soldiers were generously endowed with gifts of land, and had intermarried with the more peaceful of the Libyans. Only when the signal-fire glared from the towers, telling that some fierce band of Getulians had crept through the passes in search of slaves and booty, the bronzed veterans formed up at the camps, to guard the sacred 'peace of Rome.' Usually they looked down from their forts and 
hill-towns on the merry, thoughtless life of 'the soul of the empire,' as Salvianus calls Roman Africa. The land fell in a series of broad plateaus, with steep ridges, down to the shore of the Mediterranean. Large and beautiful towns, frequently models of Rome in African marble, met the eye at intervals, connected by the famous, imperishable Roman roads. The country was divided into immense estates, which were chiefly in the hands of the emperor or of senatorial families. Day after day the slaves and the native Libyans, reduced to the condition of labourers, or tenant-farmers, or small proprietors, toiled under the fierce African sun in the endless corn-fields, to feed the proud idlers of distant Rome-

'Qui saturant urbem circo scenæque vacantem,'

as Juvenal reminded his fellow-citizens one day. Here and there the villa of some provincial senator could be seen, unimpressive without, but equipped with extreme luxury within; and hundreds of villages were scattered over what is now the wilderness of Algeria and Tunis. ${ }^{1}$

Thagaste was a small and unimportant municipium of Numidia (the eastern half of modern

1 See G. Boissier's Roman Africa, and Davis's Ruined Cities of Numidia. 
Algeria). It lay about fifty miles to the south of Hippo (near the actual Bona), on the first of the great plateaus which ascended by steps from the sea. The distinction of the municipium and the colonia had become one of name only in the fourth century ; they were equally protected, and equally plundered, by Rome. Each town had its selfcontained municipal machinery; and, provided the taxes were paid regularly into the imperial treasury, and the corn-ships sailed in due season for Ostia, it was left to regulate its own local life. The ordinary municipal officers, the curiales or decuriones, had usually inherited the office from their fathers, and they chose the higher magistrates from their number. The barbarous fiscal system ${ }^{1}$ of Rome, which had laid a collective responsibility for the imperial taxes on these curials, was already ruining the class - the middle-class of the empire, the 'nerves of the commonwealth,' as Majorian termed them -and sapping the economic foundation of the empire. In the legislation of the fourth century we find them fleeing in despair from their hereditary 'honour'; we find the imperial officers pursuing them into the army, into the service of the palace, into the lands of the

1 Hodgkin's Italy and her Invaders. 
barbarians, into the slave-huts of the peasantry, even into the monasteries of the desert, and dragging them back to their curia; we find men forced to assume the uncoveted honour as soon as they have acquired property enough to share the financial burden. The weight of imperial taxation, added to the municipal charge, was crushing them to the earth.

For, in the economy of a Roman town, the financial burden fell upon this hereditary class of curials and the higher officials. Thus it was that, before the burden of taxation became excessive and the class reduced, the towns of Africa were enriched with many a beautiful structure. The modern traveller in Algeria still finds a noble arch of marble welcoming him amidst the mounds of ruin that were once a Roman town. Other towns had a forum with columns of marble and sculptured portico, a vast amphitheatre, a circus, an ornate temple. All had public baths with wide colonnades, spacious gaming-rooms, luxury upon luxury. The duumvir had to prove his generosity on his election, to spend fabulous sums on the decoration of the town and the amusement of its inhabitants. In the villages, no doubt, life was hard enough. The villager yoked his wife and 
his ass to his plough in the early morn-as Pliny found him in the first century and Tissot in the nineteenth-and laboured the livelong day in as happy an ignorance of economics as that of the modern Indian ryot. For the townsman life was pleasant. Augustine summed it up contemptuously at a later date as 'spectare, contendere, manducare, bibere, concumbere, dormire.' So it seemed to them also. A few years ago explorers cleared the floor of the forum in the ruins of Thamugade. On one of the slabs, which seems to have been used as a gaming-table, there was the inscription-

$\begin{array}{ll}\text { VENARI } & \text { LAVARI } \\ \text { LUDERE } & \text { RIDERE } \\ \text { OCC EST } & \text { VIVERE }\end{array}$

Their life was a remote imitation of that of great Rome. There was, in truth, more work done in Africa. It was only at Rome and Constantinople, and possibly Antioch and Alexandria, that strong men held out a shameless hand for public rations. But with their baths and circuses and pantomimes, their ignorance of politics, their genial gods and goddesses, the Afro-Romans led a merry life, while the legions kept their eternal watch on the hills. The shadow of the cross had fallen on the land, it is true, but for the vast majority it as yet 
provided only another amusement and distraction. It has been calculated ${ }^{1}$ that the Christians formed about two and a half per cent. of the population of Roman Africa at the beginning of the fourth century. Salvianus puts them in a minority even in the fifth century. But it is clear from Augustine's sermons that a large proportion of them were nominal Christians only. Africa still looked rather to the smile of Astarte than to the frown of Jehovah. Even in Augustine's greatest days he found his basilica almost empty, as he sadly complains, when his services coincided with the Saturnalia or the Floralia. ${ }^{2}$

In addition, the African Church at that time offered the pagan observers the novel and interesting spectacle of a religious schism. Africa had hitherto been of an accommodating temper in matters of theology. It had given a generous reception to the deities imported by the Punic invaders, and had readily transformed BaalHammon into Saturn, and Astarte into a kind of amalgamation of Juno, Venus, Diana, Minerva, and Ceres, out of compliment to the Romans. It

1 See Schultze's Geschichte des Untergangs des Heidenthums.

2 It is very misleading to estimate the Christian population from the number of bishops, as is done sometimes. A bishop might be no more than a village pastor, as will appear afterwards. 
was, therefore, not a little perplexed when the enterprising sect of the Christians suddenly fell into two bitterly hostile sections. It looked on with amusement at the setting up of rival basilicas and bishops, listened with interest to the loud public discussions of the morals of each other's clergy, and lent a friendly hand in the sanguinary encounters with which arguments were very frequently enforced. And the root of all this unusual excitement was-as far as the pagan could gather from the ballads which they flung at each other across the forum-not even a question of deities, but merely a dispute whether the lustral water blessed by the bishops of one faction was more efficacious than that of their rivals. ${ }^{1}$

Such was the world into which Augustine was admitted on the I $3^{\text {th }}$ of November, 354. A few years before his birth Thagaste had seen the defeat of the local schismatics and the triumph of the orthodox party. A few strokes of the imperial whip had opened minds which had been inaccessible to argument or grace for some thirtyfive years. Yet the Christian community was poor and inconsiderable. Augustine's mother,

1 The Donatist schism, of which I give here the pagan impression, will be explained at a later stage. 
Monica, was a Christian; and, although she seems to have shown no particular zeal in his early years, it is possible that her later devotion had some indirect influence on the course of his development. Augustine is obviously troubled in his Confessions about her earlier neglect, yet he has depicted her as a woman of exceptionally religious character. Her husband, Patricius, was an AfroRoman of the usual type. Very irascible and very generous, unrestrained by religious convictions or by the Christian view of conjugal duty, he is said to have yielded to his wife's importunity and accepted the restrictions of Christianity, like so many others, when his earthly life seemed to be drawing to a close. He was a curial of his native town, but of small fortune. Possibly some ancestor of his had been honoured with the higher magistracy, an elevation which had ruined many a curial patrimony. Even small towns exacted a heavy fee for such a promotion, and the duumvir who did not in addition erect a permanent memorial of his gratitude in the town might expect some discomfort. The charge was hereditary; Augustine escaped it by becoming a teacher, and thus secured the liberty to dispose of his property, which was rigorously denied to the unhappy 
curial. A brother and a sister, barely mentioned by Augustine, complete the circle of his family.

We will not follow Augustine in his stern inquiry into his behaviour as an infant. Indeed, even he, with all his sorry, eagerness to arraign his earlier self, can only conclude that he shared the vices of infants in general. His earliest recollections refer, naturally, to his school-days. The Roman boy usually began to learn his letters at the age of five or six. Frequently the mother taught him first to identify the ivory letters, and draw the stile across the waxed tablet, and count the beads on the abacus. But if his father were not of the wealthy class that hired private tutors, he was soon conducted by his pedagogue (not the teacher, but the slave who accompanied him to school) to the elementary school. The calculo or literator, as the 'first master' was called, earned a slender salary by his instructions in reading, writing, and arithmetic. An open porch, with perhaps sheets of canvas stretched from column to column at the sides, generally served as his establishment. There the little boys and girls sat together on the benches, and sang their 'twice two are four'-that 'odious refrain,' said Augustine, later-pretty much as they have done until 
recent years. Corporal punishment was by no means discouraged, and little Augustinus seems to have made a close acquaintance with the strap and rod and ferule. He felt little attraction for the early lessons, and a game at ball at undue seasons brought him many a thrashing. In naive imitation of his elders-who call the child's games 'trifles' and their own trifles 'business,' he said afterwards-he used to persevere with his game, and then beg the deity to save him from the natural penalty.

If we are to believe the Confessions, the shadow of coming sins was already upon the boy. $\mathrm{He}$ is at much pains to discover the play of his criminal instincts in his boyhood. Most of us will find a not unfamiliar corruption in his early misdeeds. He not only neglected his lessons for play, but he cheated his companions sometimes. He used to steal comestibles from the house, either for his own consumption or to bribe other boys in the interest of his games. The British boy of the twentieth century is said to have somewhat similar vices. Still, one can follow Augustine with amiable sympathy when the recollection leads him to enlarge on the alleged innocence of childhood. 'It was a symbol of humility that 
Thou didst mark in the stature of the child when Thou didst say: "Of such is the kingdom of heaven." ' 1

When Augustine passed from the literator to the school of the literatus or grammaticus, he began to feel the attraction of learning, and to earn praise as 'a youth of promise.' The grammarian was a teacher of a different type altogether from the elementary master. His school, with the curtains hanging impressively over the entrance, was an important institution in the forum. The municipality was bound to provide him with a permanent salary, in addition to the fees and gifts he received from the pupils. Though his instruction was covered by the general title of grammar, it is hardly necessary to say that this meant much more than the study which bears that name to-day. Beginning with the study of the great Latin writers, much as it is conducted in our own schools to-day, the grammarian went on to add all the liberal arts which were likely to aid in the elucidation of the text. Even in Africa Latin was the everyday language of the pupils; Punic was confined to the poorer classes, to such an extent that the Church had frequently some

1 Confessions, I. 20. 
difficulty in finding pastors who spoke the native tongue. The task of the grammarian was, therefore, something more than a mere interpretation of the text of Virgil and Horace. Every allusion to history, mythology, or science had to be followed to its source. Music, geometry, astronomy, and philosophy (to some extent) had to be imparted to the pupil. In all this Augustine found a congenial occupation, and he made rapid progress in the study of the classics. Few will sympathise with his complaint in after-years of the tears he shed over Dido's sorrows. Apart from the culture in humane feeling which they gave him, and which proved a saving grace in the temptations of his later ecclesiastical career, it would be difficult to say how largely his influence was due to his training in grammar and rhetoric. =

With the study of Greek, however, Augustine made little progress. 'I know not why I disliked Greek,' he says. The reason is obvious enough. As a boy, at all events, he disliked effort and drudgery. He had mastered the elements of Latin with some affliction, and it was natural that he should find an even greater disinclination for the elements of Greek. But the study of Greek was already falling into decay in 


\section{I4 ST. AUGUSTINE AND HIS AGE}

the Western Empire. A few youths still made their way to Athens-to be fought for by the crowd of touts at the Piraeus, and enticed from master to master by dainty dinners and pretty maids-and a few Greek sophists still lingered in the west. But Greek was ceasing to be the centre of the work of the grammarian and the rhetorician. None the less, Augustine laboriously acquired an elementary knowledge of it, and in later years he greatly improved his Greek. He handles the Greek text of Scripture with confidence in his writings; though he says in the dialogue with Petilianus (in 398) that he 'knows little or no Greek,' and admits in his De Trinitate (III. i.) that he is quite unable to read the works of the Greek fathers on the Trinity. ${ }^{1}$

The third and last stage of the ordinary Roman education-I mean, setting aside the few who were sent from the provinces to the imperial schools at Rome-was the study of rhetoric. Charged with a more or less extensive knowledge of literature, history, and mathematics, the young pupil was passed on to the rhetorician for a severe

1 The claim that he ever learned Hebrew is quite indefensible. He points out once or twice the similarity of Punic and Hebrew, but he does not exhibit a knowledge of more than an occasional word. 
training in the art of declamation. Mr. Dill has admirably shown ${ }^{1}$ that Roman culture in the fourth and fifth centuries had a purely formal and superficial aim. There was little love of knowledge for its own sake, still less of earnest philosophic inquiry. Not only was the Roman mind wholly different from the Greek in its outlook on life and its receptiveness, but the Romans had the disadvantage of approaching the higher problems only after a prolonged Greek effort seemed to have proved their insolubility. It was a sceptic who brought philosophy to Rome. By the fourth century even such philosophic work as the earlier Latins had accomplished was retiring within an ever-narrowing circle. The aim of the average cultured Roman was to afford a kind of dainty intellectual entertainment; either by elaborately wrought epistles, in which content was almost a matter of no consideration, or by rhetorical discourse. Hence the teacher of rhetoric held the first place in the educational world. When Gratian, in 376 , fixed the salary which the municipalities were to pay their teachers, he awarded twenty-four annona to the rhetor and only twelve to the grammarian. A skilful

1 See his Roman Society in the Last Century of the Western Empire. 
rhetorician not only made a considerable income, and was received with deference in the highest social spheres, but he had the popularity which now falls to the lot of a distinguished actor. When it was announced that a rhetorician of repute was to deliver a panegyric or some other discourse in the theatre, intense excitement was caused, and eager crowds filled the benches ; after a speech which repels the modern mind by its turgid flattery and strained employment of an outworn mythology, he would be escorted to his home in triumph.

Thus the training in rhetoric demanded especial care; and as Augustine was destined for the bar, there was additional reason for discretion. $\mathrm{He}$ was sent for the purpose to Madaura, about twenty miles to the south of Thagaste, one of the most important centres of Roman influence and culture in the province of Numidia, and the birthplace of Apuleius in the second century.

The removal from the influence of his mother must have been of some importance in the development of Augustine's mind. Thagaste was a comparatively Christian town, and would offer little resistance to the religious training which 
Monica was sure to give and Patricius made no effort to impair. At quite an early age Augustine had been marked with the preliminary rites of the Church by his mother during a sudden and serious illness. As he had recovered, his baptism was deferred until, to put it bluntly, he had sown the inevitable wild oats. That was a custom of the early Christians, which was grounded on a rather mechanical view of the operation of baptismal grace. But he continued to attend church with the catechumens, even after going to Carthage. Had he remained in a small town, where the old religion had little power and ceremonial glamour, the story of his later development might have been less romantic.

Madaura was an essentially pagan town. I shall deal more fully in a later chapter with the relation of the two religions, but it is necessary to point out here that Augustine passed in his fourteenth year, or thereabouts, into a wholly pagan atmosphere. He did not remain there long, and it is probable that he lived with relatives, whom he mentions in a later writing; though whether these were relatives of the pagan Patricius or of his Christian wife cannot be determined. But it is a feature of moment in our 
psychological story that the eyes of Augustine's mind are first opened amidst the full and alluring charms of paganism. The life about him gave a reality to the religious allusions of Virgil and Ovid. Remote towns like Madaura were not affected by the changes of imperial religious professions until well into the fifth century; and indeed Valentinian, who was then on the throne, interfered very little in the rivalry. Augustine recalls in later years, in two ungracious letters to cultured and broad-minded Madaurian pagans, the great statue of Mars that dominated the forum, the sight of the decurions of the town boisterously celebrating the orgies of Bacchus, and other experiences of his youth. The schools of the grammarian and rhetorician were the homes of the deposed Olympians long after the temples had been closed or destroyed. When the teaching imparted in them was enforced by a pagan life of unrestrained vitality, the effect on an impressionable youth must have been profound. Even the uncultured Christian found himself in a difficult world in the Afro-Roman provinces. They used to lay their doubts and temptations before Augustine in his later years. Was it lawful to make contracts with the natives, which only 
held when they were sealed with a score of ponderous oaths? Was it lawful to bathe with the pagans on their feast-days? What should they drink, when each well had a tutelary deity, and was tainted periodically with sacrifices to the generous giver of water? What should they eat, when every butcher's store, every vineyard, had been blessed by sending a tithe to the temples? For Augustine himself in those early days the influence must have been irresistible. In some barnlike basilica he would meet his fellowChristians, and listen to the unlettered discourse, and follow the unstimulating service; for the catechumen was excluded from taking part in so much of ritual as the Church had already adopted. Then he would go forth, and pass the doors of the temples, and drink in the sweet odour of incense and flowers, and the sound of music and singing; and mark the radiant faces and happy freedom of the outpouring worshippers; or share the intoxication of the religious processions.

When Augustine was recalled to Thagaste in his sixteenth year we can discern a change. There is an interior source of this, which will be examined presently; the long and loud iteration, on every note of the captivating eloquence 
of ritual, of the reality and supremacy of love in the life of man, had awakened an echo in the breast of the ardent youth. The withdrawal from Madaura might have been of service in meeting this new force. Unfortunately, he was withdrawn only to spend a year in absolute idleness. His father was making an effort to procure funds for the purpose of sending him to Carthage. In the meantime he had no tutor or judicious guide. 'The brambles of lust grew about me, and there was no hand to pluck them forth.' His mother? Here it is that one discerns a change, independently of the sexual development. His father noticed his maturity in the baths, and 'laughingly' announced their patriarchal prospects to Monica. She at once, and not very tactfully, approached Augustine. He waved her advice aside contemptuously as 'womanly talk.'

I reserve for a few pages such consideration of this new birth as may be necessary. In the meantime it is well to note that the only source of our knowledge of Augustine's earlier life, with one slight exception, is his autobiography. Now, the Confessions may be fine literature, but they contain an utterly false psychology and ethic. About the year 400, when they were written, Augustine 
had arrived at a most lofty conception of duty and life; he commits the usual and inevitable fallacy of taking this later standard back to illumine the ground of his early career. In the glare of his new ideal actions which probably implied no moral resistance at the time they were performed cast an appalling shadow. The astronomer has invented an instrument which dissipates the excessive splendour of the sun, and permits him to examine its disc in broad daylight. We must use something like a moral spectroscope, a humane discretion, in approaching Augustine's unregenerate life in his Confessions. 


\section{CHAPTER II}

THE THIRD CITY OF THE EMPIRE

DURING the year which followed his withdrawal from Madaura Augustine lost his father. From the point of view of his mental and moral development this was an event of no great importance. The days had long since passed away when the Roman father exercised a despotic authority over his children, having the power of life and death over them, and the right to sell them into slavery. In the fourth century the life of the family differed little from the aspect it presents to-day; indeed, we find St. Jerome, in one of his letters, praising the action of a young Roman girl who sold her jewellery, in a fit of piety, without consulting her parents. Very frequently the relation of father to son was one of strong personal affection and constant assistance-as in the case of the senator Symmachus, and of Augustine towards his own son. But Patricius seems to have trusted largely 
in this matter to the general benevolence of the fates. He was, however, exceptionally eager for his son's advancement in the schools, and earned quite a distinction in Thagaste for his efforts and sacrifices. Happily for Augustine-and the Church, perhaps - a second father, a very generous patron, was immediately found. This was one of the leading decurions of Thagaste, a very wealthy man of the name of Romanianus. $\mathrm{He}$ at once began his career of generosity by finding the money for Augustine's journey to Carthage.

Roman Carthage must have fallen little short of the great city which was ruthlessly destroyed by Scipio in 146 B.c. For seventeen days the Romans had gloated over the flames that devoured the last stone of their historic rival. In I22, and again in 29 B.c., colonies were sent out from Rome for the purpose of rebuilding the city. It is now generally agreed that the new city was built on the bed of ashes that represented all the glory of the Phœnicians. The two harbours were again lit up with the colour and echoed with the life of merchant galleys and Roman triremes. The neighbouring hill, the Byrsa, was crowned once more with a great temple of Esculapius. The forum rang again with the jokes of idlers and the 


\section{ST. AUGUSTINE AND HIS AGE}

swift rush of chariots ; the 'street of bankers' was a sight of the world, in its glory of marble and gold; the 'esplanade' drew crowds of wondering rustics to its famous mosaics, representing the giants and pygmies, the one-eyed, dog-headed, immense-footed, and otherwise abnormal races that lived beyond the hills. The temple of Saturn (formerly Baal-Hammon, or Moloch) was rebuilt; though it contained no longer the cruel image that had once received the babes of the citizens into its furnaces. The temple of Astarte or Tanit was rebuilt on a magnificent scale, and was girt about with a vast zone of minor temples within its two-mile enclosure.

For the Carthaginians were an intensely religious people. Their ardent and sensual temper had found, or shaped, a religion in which their strongest impulses were consecrated, and they clung to its spectacular ceremonies with a not unnatural zeal. It has often been pointed out how faithfully the heaven of the uneducated believer reflects his temperament and habits : how the converted Indian aspires to a happy huntingground, the Neapolitan fisherman to a land where he may have unlimited absolution and maccaroni, 


\section{THE THIRD CITY OF THE EMPIRE 25}

and the respectable Teuton to 'a huge Gothic cathedral in which he may praise the Lord for all eternity.' That feature is notoriously prominent in the intermediate forms of religious development. And Carthage had imported its gods and goddesses from the hot unhealthy East.

Probably one of the first sights to arrest the thoughts of the young Augustine in the great city was one connected with religion. One could not go far in the streets of Carthage without meeting a number of strange creatures - men who had divested themselves of the last trace of manliness. They wore the bright flowing tunics of women, their yellow skin was elaborately powdered and the lips a brilliant red, their voices were highly-pitched and squeaky, their hair wet with perfumed oil, their fingers glittering with diamonds, and they studiously imitated the gait and demeanour of women in every movement. They were the sexless priests from the great temple of Tanit, parading their repulsive condition and still more repulsive practices ' in every street and square of Carthage.' Rome had suppressed the earlier features of the licentious cult of Astarte, when each temple was one vast sacred lupanar; but it did not interfere with the more pernicious 
practices of these eunuch-priests, in the worship of Cybele (or ' the mother of the gods'), and Tanit (or 'the celestial virgin'), which had long since so deeply stained Greece and Rome with unnatural vice. ${ }^{1}$ When the city was rebuilt by Augustus, the temple of Tanit was restored in splendid proportions. A contemporary writer (known as 'Prosper'), who saw it first converted into a Christian temple and then destroyed, a few decades later, describes it as one of the wonders of the world. But the Romans knew not Tanit, and spoke confusedly of Juno, Venus, Diana, Minerva, and Ceres ; so, by a happy compromise, it came to be known as the temple of the 'celestial virgin,' or, briefly, the temple of the 'cœlestis.' Its worship, like the cult of Saturn and Æsculapius, was in full vigour until about 39I. The proconsul

1 I am aware that Mr. Davis, in his Carthage, questions whether the Carthaginians ever admitted in their worship of Tanit the grosser features-of which the curious reader will find a description in M. Pierre Louys's Aphrodite-which were associated with the cult of Astarte (the Syrian equivalent of the Persian Tanit, the Greek Aphrodite, and the Latin Venus) in the East. But his data are very slender, and he himself gives a quotation from Augustine which outweighs them. I would also recommend the serious student of ethics and sociology to consider the very curious instance of religious taboo which is probably at the root of this appalling development of sacred prostitution, and the physical and physiological causes which were at work in the rise of unnatural vice in the East. These are well indicated in Rosenbaum's Geschichte der Lustseuche im Alterthume. 
Tiberius had suppressed the fiendish elements of the cult of Saturn by hanging its obstinate priests on the trees surrounding their temple. Christianity found a much pleasanter way of extinguishing the cult of ' the celestial virgin.'

The second great passion of the Carthaginians was for games and spectacles. In this they were not second to the Romans themselves. Salvianus, indeed, would have us believe that they were not even awakened to the serious issues of life when the Vandals were thundering at their walls. 'The voices of the dying mingled with the cheers of the spectators,' says that sombre rhetorician; 'you could hardly distinguish the groans of those who fell in war from the applause that rang from the circus.' For the games of the circus-chiefly chariot-races, wrestling, tight-rope dancing, etc.Augustine seems to have felt little attraction. We shall find him bitterly and contemptuously inveighing against them long before his conversion. Nor does he seem ever to have looked with favour on the bestial pleasures of the amphitheatre, where the gladiators fought. Yet these contests had an irresistible fascination for the Carthaginians. Years afterwards, when Augustine came back to Africa one of the most powerful preachers in the western 
Church, Bishop Aurelius would invite him to come and preach at Carthage on the day of the munera, or the gladiatorial display. He sadly confesses ${ }^{1}$ that a congregation of Christians could not be mustered on such days.

= On the other hand, he was found frequently enough on the benches of the theatre. The theatre was a peculiarly mixed institution in the Roman world. It was there that rhetoricians delivered their ornate discourses, and aspirants to the art contended for the crown. Yet it seems clear that Augustine went there for other than intellectual feasts. The drama was greatly neglected in the closing years of the empire, and the stage was used for an exhibition of coarse and stupid buffoonery. Conjurers and acrobats were provided, but the chief attractions were the ribaldry of the mime and the frequently obscene performance of the pantomime. In the fourth century actors and actresses were treated as a class beyond the pale of moral feeling, and they had their revenge on the morals of their superiors. Christian bishops, wiser in this than the men of state, wrung some unwilling recognition of their human dignity from the emperors, but it was often re-

1 See Sermon 19, for instance. 
called. Thus in $4 \mathrm{I} 3$ we find Honorius directing the 'tribune of amusements' at Carthage to recall to the service of the theatre the actresses who had been released by 'imperial kindness' (probably at the request of the African bishops). Their function was hereditary ; conversion to Christianity was the only channel of escape from the degraded service (one of the many short-sighted privileges secured by the bishops which accelerated the growing corruption of the Church); and a single lapse from their converted condition bound them again to the theatre for life. In Procopius's Secret Life: there is a candid picture of their moral condition. In the theatre they had practically an unrestricted licence. The mimes exchanged ribald jests with each other and the audience, and freely caricatured the grosser features of the State-religion (e.g. the cult of Priapus, which was still maintained), and offered other spectacles, the worst of which still linger under the shadow of the law in modern Paris. The pantomimes had to represent something like our plays without words. They-there were male and female characters-had to picture by gesture and movement alone adventures from the poets, the popular mythology, etc., including, of course, the adventures of Jupiter. 
I have said enough for the purpose of enabling the reader to realise the moral atmosphere into which Augustine was now introduced. It was wholly morbid and vicious. Salvianus, the priest of Marseilles, who wrote with a view to proving that the barbarian invasions were a Providential punishment for the vice of the empire, declared that Carthage was 'the cesspool of Africa, and Africa was the cesspool of the world.' In another place he says that 'you might as well say an African was not an African as say that he was chaste.' The Romans had brought all their pleasures and their vices with them into the new colony; no exiled Roman citizen was allowed to settle in Africa-it was too Roman. And the East had transmitted, with its slaves and spices, some of its most morbid practices. However, the analysis of cesspools is not an attractive study, and these general indications suffice for our purpose. But it is necessary to point out that the growth of Christianity in the city of S. Cyprian had had little influence on its life. The vehemence of Salvianus-a Christian priest-is directed equally against the Christians and the pagans. The acta of the Councils of Carthage tell a sorry story. Gibbon has given some curious facts with regard to the morality of 


\section{THE THIRD CITY OF THE EMPIRE $3^{I}$}

its clergy even in the days of persecution; and there is many a parallel to them in the writings of St. Chrysostom, St. Jerome, and St. Augustine in the fourth century. In the sermons which Augustine preached at Carthage we have a clear reflection of the morals of the Carthaginian Christians. $\mathrm{He}$ is evidently addressing a congregation with only the most rudimentary feeling of moral law on sexual matters. One source of evil was the vague belief that sins committed before baptism had an entirely minor gravity, and the Church made little effort to resist this fatal postponement of baptism. A second difficulty was that the Christians fully shared the typically Roman notion of sexual morality. Under Roman law the criminal intercourse of two married persons was punishable with death, as was also the violation of a free woman. But extra-matrimonial intercourse was disregarded, as well as all intercourse with slaves. It came, therefore, to be regarded as moral principle-when that idea was introduced to the Christian populace-that only complete adultery was forbidden. Augustine argues passionately and painfully with his hearers on the point. But it is quite clear that, apart from the adultery which was explicitly given in the commandment, his 
argument must have been entirely unconvincing to such an audience. Moreover, Augustine and his fellow-saints developed excessively ascetic views about sexual matters; and the people, in reaction on the obvious exaggeration, would be sure to draw the line very low. Briefly, although Christianity had, with imperial assistance, virtually conquered Africa when the Vandals arrived in 429, it had not conquered, but had been conquered by, its vices. It was reserved for the chaste Vandals - that 'army of Puritans,' as Mr. Hodgkin (following Salvianus) calls them-to remedy in a day the corruption that Christianity had failed to overcome. Genseric found Carthage, Christian and pagan, says Salvianus, in a condition of revolting public disorder. The Vandal chief-let us not use the word 'Vandal' too lightly-strode in sword in hand, married or banished the women, and purified the long-sullied streets of Carthage. ${ }^{1}$

But we are anticipating. In 370 Carthage was 'full of people, and yet more full of infamy.' Augustine was not there many months before he

1 The Vandals were Christians-Arians or Unitarians-recently converted. But no one questions that the zeal for chastity with which Salvianus credits them and the Goths was a survival from their 'paganism.' Carthage had been Christian for thirty years at this time. 
formed 'a connection'- - to express it in the safe terms of an ecclesiastic, Mr. Marcus Dods'which was not matrimonial in the strict sense.' It may be briefly noticed that biographers differ in their appreciation of the steps by which Augustine descended to this condition. As in the somewhat analogous case of Pierre Abélard, the autobiographer has used language so vehement and sombre in speaking of his misdeeds, that he is often awarded a larger amount of wickedness than he is probably entitled to. He was in his eighteenth year when he took to himself a mistress. His words seem to imply that this was the culmination of a couple of years of corrupt living. It is hardly worth while making a severe research into the matter, but justice to the young Augustine impels us to submit one or two considerations. In the first place, Augustine is sternly bent on magnifying his misdeeds in his Confessions. The solemnity with which he enlarges on the theft of a few pears in his sixteenth year should make us accept his phrases with some discretion. Then we have an interesting witness to the light in which he was regarded by his school-fellows at Carthage. In later years, Vincentius, a Rogatian (heretical) bishop, admits, in writing to him 
(ep. 93), that he was considered 'a quiet and respectable youth.' Augustine himself says that he refused to associate with the more disorderly students. He describes a group of them, who seem to correspond very closely to the 'Mohawks' of older London. They felt flattered by the title of the 'eversores' (upsetters), and endeavoured to deserve it by the maltreatment of peaceable citizens. A more general defect was the habit of breaking in noisily upon the lectures, and creating disturbances in the schools. Augustine shrank even from this lesser and more general misdemeanour. Indeed, he writes that he was driven to lying for the purpose of making himself the peer of his school-fellows in vice. The admission reveals a certain weakness of character, but it seems to point to an exceptional aversion from vice in a youth of his age and circumstances. Finally, the fact that he was faithful to his mistress for fourteen years implies a (for those days) rare moderation of character. Salvianus would have us believe that such a fidelity, even amongst the married Christians, was almost unknown in Africa; and his statement finds grave confirmation in Augustine's own sermons.

If, then, we bear in mind that Augustine was 


\section{THE THIRD CITY OF THE EMPIRE 35}

an Afro-Roman youth of the fourth century, we shall not find it necessary to borrow the depressing phrases of the ordinary hagiographer. He was, comparatively, 'a quiet and respectable youth.' Hatzfeld finds that he was 'troubled by the importunate reproaches of his conscience.' There is no trace in the Confessions that his conscience had anything to say at the time. Hatzfeld commits the familiar anachronism of the hagiographer. For my part, I think it more profitable to study events in the century and the environment in which they occurred, and I am forced to conclude that Augustine's conduct in his youth was unusually regular. We have an interesting poem by Paulinus of Pella, a grandson of the poet Ausonius, which affords a valuable insight into the mind of even the Christian community of the fourth and fifth centuries on these matters. Paulinus, a wealthy Roman of Aquitaine, had become a notably religious man after the barbarian invasions; and in the retirement of his villa, in his eighty-third year (about 459 в.c.), had written a pious and penitent autobiography, with the title of the 'Eucharisticos.' The writer innocently remarks that he was careful to guard 'the treasure of chastity' (carum pudorem) in his later youth; 
which means, he goes on to explain, that he avoided rape and adultery, and 'was content with the use of the slaves of his house.' As M. Boissier says, the female slave regarded ministration of this kind as a normal part of her service. It does not seem likely that Augustine's mistress was a slave; though he tells us nothing of her beyond the facts of her introduction to his home and dismissal from it, after a faithful attachment of fourteen years, that he might marry one who seems to have been richer. Finally, to put a term to this very necessary examination, it must be noted that Augustine blames his parents at this period for not marrying him (a matter which concerned parents rather than the marriageable parties in ancient Rome) at once, and saving him from disorder. They were, he complains, too eager for his advancement in the schools. Probably, too, Monica found some consolation in the current Christian phrase : ' $\mathrm{He}$ is not baptized yet.'

In the meantime, Augustine was making good progress in his studies. He does not hesitate to tell us that he was distinguished for an excellent memory and an unusual penetration for his age. And as, with his advance in rhetoric, he entered upon a more systematic study of the 
subsidiary sciences, the field of learning began to open before him with an alluring prospect. It was a period when the distinction of the seven liberal arts was taking shape. Donatus, the great authority on grammar for so many centuries, was even then teaching at Rome, numbering amongst the youths who crowded his benches an ardent young Dalmatian of the name of Jerome. Under his influence the work of the schools was assuming the form it was to keep until well into the Middle Ages. Latin translations of Aristotle formed the base of the study of logic. Music was studied with some ardour; even Ammianus allows the fourth century a zeal for music. Grammar and rhetoric were the two great studies, as I said, overlapping all the rest at that time. Arithmetic, geometry, and astronomy were also already taking distinct form.

It was in the pursuit of the last three sciences that Augustine was led into his first intellectual cul-de-sac. Far down into the Middle Ages the study of 'mathematics' was regarded alternately with suspicion and derision. Abélard speaks of it as 'a nefarious study.' The casual reader of the Theodosian code, that profoundly interesting mirror of the life of falling Rome, is still further 
perplexed by finding the sentence of deathfiercely decreed and brutally directed-passed on 'mathematicians.' The modern mathematician being an exceptionally innocent personage, as a rule, one wonders what strange and misleading garb was worn by his ancestors. It is even contended by some recent German scholars that Hypatia was so foully murdered by the people of Alexandria because of her repute as a mathematician; that is to say-for no one now questions that the murder was perpetrated in the interest of the Churchthat the features of especial brutality which are recorded seem to have been inspired by the law against mathematicians.

The truth is that mathematics had formed an incongruous and somewhat dangerous alliance with astrology, divination, and fortune-telling. Even in the eyes of the law mathematici are taken to be the same people as the ubiquitous astrologers, or genethliaci. In his Doctrina Christiana, Augustine attacks "divination, which he calls 'a kind of fornication of the soul,' with remarkable energy, and he renews the attack incessantly in his sermons and writings. That is how most of us deal with the errors which we 'find out.' Augustine plunged deeply into astrology and divination 
soon after his arrival at Carthage, and retained his belief in it until near the time of his conversion. There were, indeed, few who escaped the contagion of the popular belief. Divination was, of course, a religious truth at that time. Centuries of experience had not impaired the popular trust in the predictions of oracles, auspices, haruspices, and the whole army of fortune-tellers connected with the pagan religion. The Christian was no less willing to admit the faculty than the pagan; he had angels to work his own oracles, and devils for those of the heathen. As a result, the practice of divination had permeated the whole public and private life of the empire. Every village had its astrologer and sorcerer. The stars were consulted whenever a tree was planted or a cow was to be mated. The astrologer had to say whether the newcomer would be good for milk, or draught, and so forth. Many even had the course of the planets carefully considered in the matter of their own offspring, choosing moments of ' a favourable conjunction.' ' Whenever anything was lost, the diviner was consulted. In his work Contra

1 As Augustine afterwards said, in the City of God, the advent of twins, with different temperament and fortunes, was the great crux of the genethliacus. 
Academicos, Augustine tells how he and some of his pupils went to consult a diviner of the name of Albicerius about a spoon they had lost. Albicerius found the spoon for them-so says Augustine, who remains a model of trustfulness throughout life-and added many other marvels. He disclosed to them that the slave who carried the purse had helped himself from it on the journey; and he told them any passage of Virgil they cared to think about. ${ }^{1}$ On another occasion Augustine was going to compete for a prize in the theatre by the delivery of a rhetorical discourse, and he was approached by a kind of private haruspex, who promised to discover his chances for a consideration. It says much for Augustine's character that he repulsed the man vigorously, in spite of his superstition; "though the crown were of imperishable gold, I would not suffer a fly to be killed to gain it for me.'

It must not be supposed that Rome was actuated in its repeated fulminations against

1 Augustine afterwards attributes the man's skill to the devil's assistance. Cardinal Rauscher, the chief biographer of St. ! Augustine, adds a number of similar marvels that were performed under his own eyes in modern Germany ; in the meantime the devil has retired, and the events are explained scientifically. But I must warn admirers of Lytton's views on such matters that Albicerius is described as a man of notoriously vicious life. 
THE THIRD CITY OF THE EMPIRE 4 I

divination by the paternal feeling for the credulous which inspires our modern laws against palmistry. The emperors had discovered that, in that age of short leases of imperatorial power, ambitious officers were tempted to consult diviners as to the next successor to the purple; and it was not unjustly suspected that the honour of the diviner's profession might be unduly preserved, when a prediction had been given and paid for, by a little artificial assistance judiciously applied to the natural course of events. Constans and Constantius, Valens and Valentinian, passed drastic laws for the extinction of secret divination. A few years before Augustine came to Carthage there had been a fierce persecution of diviners throughout the empire on account of a consultation as to the imperial succession. The manner of going to work is curiously described by Ammianus Marcellinus. A tripod table, made with branches of laurel, was set up in a strongly perfumed chamber. On the table was a basin of various metals, having the letters of the alphabet engraved round the rim. Over this a ring was suspended, and was set in motion by a man who stood beside it clothed in white linen and with verveine in his hand. The ring then spelt a 
message in much the same fashion as is done on the modern 'ouijah' board.

All the Christian orators of the time denounce the popular recourse to divination unceasingly. They plainly intimate that the Christians are as bad as the pagans. Indeed, it was only the more stern priests of the Church who offered a consistent opposition to it. St. Jerome tells a story which doubtless illustrates a good deal of Christian as well as pagan life. St. Hilarion, he says, was approached by a wealthy Christian who was about to compete in an important chariot-race, but whose horses had been paralysed by the magical rites of his adversary. Hilarion resisted the man for some time, but at length gave him his drinking-cup full of water to sprinkle about the stable. The charm was broken, the race won, and the Church gained a large number of 'converts.' Again, when Rome was threatened by the Goths in 408, a body of Tuscan diviners presented themselves to the prefect, and offered to call down lightning on the barbarians, as they had done before. The prefect consulted Pope Innocent, who was willing that the Tuscan priests should have a trial, but not in public. The Tuscans, of course, declared 


\section{THE THIRD CITY OF THE EMPIRE 43}

that their sacrifices would be unavailing if not performed with becoming solemnity, and Rome fell. But in the meantime Pope Innocent secured another severe law against the mathematicians. His situation had hardly been one of dignity or comfort.

Augustine retained his belief in the powers of / the astrologer for a number of years. He was severely taken to task for it by the proconsul, Vindicianus, who crowned him after a prize oration in the theatre, and who seems to have taken a warm interest in his progress. A favourite pupil of his, Nebridius, also continually ridiculed his belief. But it was not until he had made considerable progress in astronomy, and was faced with a large number of failures to predict, that he parted with a belief which had afforded him amusement, if not enthusiasm, for so many years. $\mathrm{He}$ then, as is the wont of such characters as his, takes a most sombre view of his old opinion, and denounces it and its supporters in embittered terms. 


\section{CHAPTER III}

MENTAL GROWTH

In this whirlpool of life at Carthage in the fourth century Augustine spent his eighteenth and nineteenth years. It is true that he was already lifted above mediocrity, not only by an exceptional ability and some refinement of character, but also by an aspiration. He had ambition and an ideal. He was already conscious of a spark of the ethereal fire that burns in the soul of the elect, and was resolved to plough his way across the common furrows of life. But his ambition was purely selfish and his ideal earthly. Advancement in the schools, distinction at the bar, wealth, the repute of eloquence, and possibly, in the end, senatorial dignity. Perhaps it was, after all, a commonplace ideal for a Roman youth. At all events, his vision was bounded by the farthest horizon of the life that surrounded him. But one day, in his nineteenth year, a strange light 
fell on his mind, and gradually there came into his vision the lines and peaks of the eternal hills beyond, the irresistible splendour of the intellectual ideal, far outshining the glitter of his ambition. And the poor pilgrim of truth set out on the eternal quest.

The accident that thus kindled into full flame the idealist force in Augustine was the reading of a lost work of Cicero. In the ordinary course of his studies-though Augustine's could hardly be called an ordinary course: he mastered the Categories of Aristotle without assistance in his twentieth year - he came to take up Cicero's Hortensius. It changed at once the whole colour of his thoughts and aspirations. 'Forthwith all vain ambition fell from me, and I longed, with an incredible ardour of soul, for the immortal treasures of wisdom; I had begun to arise, that I might return to Thee.' In his later piety Augustine probably assigned too definitely religious an impulse to the reading of the Hortensius. When he says that 'the only thing that troubled me in my new-born ardour was the absence of Thy name from the book,' we may respectfully decline to follow him; it is by no means the only instance in the Confessions of a 
fore-shortening of his psychic perspective. Yet it is clear that the work at once gave a new direction to Augustine's thoughts and purified his ambition. 'At that time my sole delight in that exhortation was that it spurred me on to love and seek and attain and embrace, not this or that sect, but wisdom itself, wherever it might lie;' and he adds in the Soliloquies that it cured him of the thirst for wealth. The Hortensius was written by Cicero as an exhortation to the study of philosophy. It is a pity a work of such force has perished; but it must be pointed out once more that the moral of the Hortensius could not have lit this flame in the mind of the youth if he had been as corrupt in those unregenerate days as he himself and most of his ecclesiastical biographers pretend. The humanism of the twentieth century will surely refuse to allow any longer this distortion of an orderly psychic growth in the interest of a dogma.

I have already pointed out that the study of philosophy was all but dead in the Western empire in the fourth century. The schools of Alexandria cultivated the study until much later (Mr. Kingsley's novel departing very widely from historical truth in this and other important 
respects), and Augustine's correspondence will introduce us to a number of isolated students and followers of the thoughts of Plato; but philosophy had few votaries and fewer shrines. The grammarian and the rhetorician only imparted such fragments of it as they found convenient. Hence Augustine obtained little more assistance from them than an indication of the few works available in Carthage. There were large towns in Africa (such as Hippo) that had not even a copy of Cicero. The young 'seeker of wisdom' had to push his Sisyphean stone alone.

In this absence of an orderly philosophical training or a large philosophical literature, and seeing that he still attended church sometimes (Conf. iii. 3), it is natural to find him turning first to Scripture for enlightenment. 'But it seemed to me,' he says, 'unworthy to be compared with the majesty of Cicero.' There came a day when Augustine found deep and accurate science in Genesis, a 'mystic' beauty in the lives of the patriarchs, a surpassing eloquence in the Gospels, and a supreme reasonableness in Paul's demand that we shall close our eyes and obey him. In his twentieth year it impressed him as 
it impresses most of us in our twenties-if we chance to read it-and some of us throughout life. The stern voice of Paul of Tarsus, denouncing philosophy as folly and the simple demand for evidence in a world of lies as arrogance, repelled him. The strange story that ran so unevenly through the unlettered gospels required some proof; and Paul merely flung back his questions with disdain. Was he to submit implicitly to these apparently ignorant men? It was Cicero who had lit up for him the vision of the far-off hills where truth dwelt; he expected to feel the solid ground beneath him, and see the path ahead at every step. Moreover, truth was to bring harmony into his thoughts; this story of Christ only widened the gulf between his idea of God and his experience of life. He closed the Scripture, not in pride but in perplexity and sorrow, and looked out on the ways of life.

Harnack has said that the three religions which disputed the soul of humanity in this fateful fourth century were Christianity, Neo-Platonism, and Manicheeism. Others regard Mithraism as the serious rival of Christianity; the popular impression would have it to be the ancient Roman religion. Certainly, what was already being called 
'Paganism' was dying. For many centuries it had sheltered Rome, but corruption was eating into its heart, and the yellow leaves were falling on every side. Either Platonism or Mithraism formed the core of whatever religion the cultured pagan still retained, as will be seen presently. In Western Africa these two religions were inconspicuous; its bald polytheism, unidealised by Neo-Platonic symbolism and unanimated by Mithraic emotion and ethic, never appealed to Augustine. He takes credit to himself that he never, at any moment of his life, questioned the existence of God. His idea of a philosophy or of truth was of something that would illumine the seeming chaos of life with this thought. Paganism was to him in his rationalist mood merely an outworn, tinselled garment, clothing a dead idol. He turned perforce from Christianity to Manicheeism, a religion which had a considerable and a cultured following in Africa.

Manicheeism has been persistently misrepresented by Augustine's biographers; even $\mathbf{M}$. Poujoulat gives a fantastic version of its origin and an ungenerous exposition of its doctrines. M. Beausobre, its classic exponent, contends that Augustine himself misrepresents it. Assuredly 
Augustine has not the habit of presenting the errors he once held in the light in which they must first have appealed to him, but it is likely that he correctly describes, on the whole, the Manicheeism he embraced in the fourth century; this may have differed as much from the teaching of Mani as fourth century Christianity departed from the teaching of Christ. Indeed, there is much obscurity about the origin of the religion. It is now generally agreed ${ }^{1}$ that the Christian tradition on the subject is unworthy of credence, and the Mohammedan alone reliable. According to this, Mani, the founder, was a Persian noble of some culture, born at Ecbatana, probably about 2 I 5 A.D. Starting from the groundwork of an ancient Babylonian nature-religion, and adding, as he proceeded, elements from Parsism, Christianity (probably through the Gnostics), and possibly Buddhism, he finally presented to the world what purported to be a complete philosophy of life.

Whatever may have been the sources of the Manichean doctrine, Augustine was initiated to a plausible and impressive system when he sought instruction. To one who, like Augustine, held

1 See 'Manicheeism ' in the Encyclopadia Britannica, a most instructive essay by Professor Harnack. 
the being of God as a first principle with which the world must be forced into some kind of harmony, the power of evil would be the most arresting aspect of life. The Manicheans had a ready answer. The human heart was right, they said ; evil did not come from God. There were two eternal principles - the good and the evil, light and darkness. This chequered world, with its alternate triumph of light and shade, its everchanging song and dirge, was the battle-ground of their conflict, the outcome of a confusion of their kingdoms. So much the very face of the world proclaimed. And imagination soared back down the ages to a time when the two kingdoms-of light and of darkness-were separated. Imagine a conflict of the good and the evil powers; a partial victory of Satan and invasion of the kingdom of light; the birth of a world of these commingled elements; the creation of man, a creature of light, and his defeat and corruption by the demons. Imagination has constructed the very world that lies about us, the very nature that is in us : to them it appeals for proof of the 'revelation.' Henceforward life is a stern process of redemption, an eternal struggle of the elements of light to break free from the kingdom of dark- 
ness, and return to their source. There have been poorer theories framed in Germany in the nineteenth century, theories that have less echo in man's consciousness and less guarantee in the broad features of the world.

The moral system which was founded on these speculations will be readily conceived. It embodied the superficial lesson which nearly all great religions thought they gathered from the very heart of life-asceticism. From all their different starting-points, with all their varied notions of deity, the great religions have, nevertheless, singularly agreed in exaggerating the lesson of moral equilibrium which nature urged. Manicheeism was peculiarly disposed to emphasise this. Its morality was identical with its physics. Physical light was moral good, and physical darkness evil ; and the process of severance was at once physical and moral. Hence the reaction, the inevitable revolt of nature, was swift and sad. Manicheeism drew a distinction like that of the Church between its elect and its catechumens, or auditors; and the latter, like the unbaptized Christians, lived very much as they liked. Augustine, at a later date, makes great effort to asperse the character of the elect, of whom he retails many hearsay scandals. 
It would be a moral miracle if there were not hypocrites amongst them, but Augustine's tirades have something of the tone of 'the escaped monk.' Yet an impartial study of all that we know of Manicheeism at the time-though we know it only from its enemies-seems to discover it to be rather an intellectual clique with little moral earnestness. It survived until late in the Middle Ages, yet one finds it hard to conceive it as a serious rival of Christianity. Its 'reformed' section, its Puritans, were gathered into a sect called the mattarii in Augustine's day. One of those wealthy zealots, who are at once the treasure and the terror of all sects, tried to initiate a higher life at Rome. He attracted a large number of the elect to his house, and they drew up an ascetic scheme of life. Augustine is never tired, in his later years, of describing the result. One by one the elect retired to their comfortable homes, and the sect of 'sleepers on mats' that finally clung to Constantius, until his secession to Christianity, was very slender.

It must, however, be pointed out that this simple basis of theory and ethic was overlaid with a towering structure of dogma, ritual, and organisation. The Oriental imagination filled in the 


\section{4}

ST. AUGUSTINE AND HIS AGE

details of the primitive fable; the growing hierarchy, as is usual, ' discovered' fresh Scriptures. Thus was gradually built up the singular structure which thrusts its bizarre features upon us from every page of Augustine's writings. In streaming upwards from the earth to its natural reservoirs, the sun and moon, the light was intercepted by the roots of plants and trees; it was absorbed into their structure, and revealed its divine presence in the glory of flower and perfume. Hence the Manichean horror of plucking flowers, vegetables, or fruit. This was met, however, by a belief - a belief which chanced to be, as sometimes happens, extremely advantageous to the clergy - that when the elect eat these fruits or vegetables, they set free the divine light to continue its upward journey. Hence, although they were vegetarians and celibates-there being no light to deliver in dead flesh, and procreation being a multiplication of evil-the elect had a not unpleasant existence. Augustine would have it that their life was a continuous banquet of the choicest fruits, cakes, truffles, artichokes, and sweet wines, contributed in vast quantities by the auditors (uninitiate). Such a system would inevitably lead to grave abuses. Moreover, as the 
conduct of the auditors was little controlled, and the peculiar tenets of the elect as to sexual matters seem to point to grave disorders, it is probable that Manicheeism did no more than Christianity towards the purification of the empire.

Augustine seems to have felt some enthusiasm for his new religion, or rather philosophy, during the next few years. We may generously decline to take quite literally his later lament in the $D e$ dono perseverantice that he 'had devastated the Catholic faith,' but he won over a number of his friends to Manicheeism; whatever evil he achieved in that way was fully atoned by his later treatment of his old religion. For a few years he was genuinely captivated by the fine simplicity and plausibility of its main gospel. The Manichees rejected the Old Testament, and they encouraged youths like Augustine to make merry over the lives of the patriarchs; this also he atoned for later on by his 'mystic' treatment of their Oriental ways, though they long eluded even his respectful efforts to explain. Presently we shall find him looking more critically into the system. For the moment it succeeded where Christianity had failed. He wanted a religion which should explain the world to him, and the Manicheans 


\section{6}

ST. AUGUSTINE AND HIS AGE

gave, on the whole, a plausible interpretation of it, as it appeared to him.

He was in his twentieth year when he embraced the religion of Mani, and it seems to have been shortly after this that he finished his studies at Carthage and returned to Thagaste. Monica was profoundly troubled about his lapse. She seems to have accepted his companion without a murmur, but the descent into heresy was an unpardonable depth. She refused to sit at the same table with him, and it seems likely (Contra Academicos, ii. 3) that he lived with his patron Romanianus. But Monica was soon happily released from the painful duty her conscience had imposed. She was assured in a dream, that happy and familiar medium of celestial communications, that Augustine would one day return to Christianity. That seems to have quite removed the sting of the actual sin. She found further consolation in the well-known assurance of a bishop, whom she vainly begged to argue with her son ("he said I had already given much trouble to the unlearned by my questions,' says Augustine), that 'the child of those tears could not perish.' From that date Monica entered upon the long and passionate devotion to her son's conversion which has earned 
for the simple, ignorant woman an immortal place amongst the mothers of men.

For some reason which Augustine does not mention, probably for want of funds, he ceased to look to the legal profession, and opened a school at Thagaste. In the Confessions he says that he taught rhetoric there, but his disciple and biographer, Possidius, says he taught grammar at Thagaste and rhetoric at Carthage. This is much the more probable; Augustine's chronology is a little confused in the Confessions. Here he gathered about him a number of admiring pupils, some of whom clung to him throughout life. 'I preferred good students,' he says. The Hortensius had moderated his desire for wealth, and he would find it possible to combine his philosophic studies with the instruction of a few quiet youths. It was about the time when (in 376) Gratian ordered the municipal councils to pay a regular fee to their teachers; and with this, the usual gifts from pupils, the patronage of Romanianus, and a moderate private income, Augustine would be in a comfortable position. His life-long friend and 'little slave' Alypius, son of one of the leading decurions of Thagaste, and two sons of the wealthy Romanianus, were 
amongst his pupils, and it was not long before most of his friends were Manicheans.

In the course of a year or two we find him returning to Carthage, and opening a school of rhetoric there. In his Contra Academicos (ii. 3) he admits that ambition had some share in the change, but in the Confessions he assigns a cause which leads him to write some fine passages. About a year after his return to Thagaste he lost his most intimate friend. The youth had studied with him, and had been converted by him to Manicheeism. He contracted a dangerous fever, and died in Augustine's absence. The beautiful passage in which Augustine expresses his grief thirty years afterwards reveals a singularly deep affection. 'My heart was darkened with sorrow ; whatever I looked upon was death. My country was a torment to me, my father's house a strange affliction; whatever I had shared with him seemed to become, without him, an unendurable torture. My eyes sought him on every side, and he came not. I hated all things, because they held him not; nor could they say to me, as they were wont to do during his absence, while he yet lived, "Behold, he comes." I found myself one ceaseless question, ever asking my soul why it was sad, 
and why it afflicted me; and it knew not what to answer me. . . . Weeping alone brought me some sweetness, and took the place of my friend in my heart. . . . I bore about a soul that was rent and bleeding, impatient of my bearing it longer, yet I found not where I might lay it down. Not in pleasant groves, nor in game and song, nor in perfumed chambers, nor in rich banquets, nor in the pleasure of the bed, nor in books or poetry, could it find rest. The very light of day was odious to me; and all that was not like him, except groans and tears, was a thing of hate and affliction. In tears alone did I find some rest.'

The love that speaks thus after a silence of thirty years-and such years as Augustine had seen-was assuredly 'stronger than death.' Unhappily, these beautiful pages of the Confessions are marred by the painful exaggeration of Augustine's later attitude. No one can read without deep respect and sympathy Augustine's eloquent claim that even this human love must be sanctified in God and supported by the clear vision of immortal life. But it is another matter when he goes on to denounce 'the impurity of such affections,' because they remain on the level of humanity. There are some who think the violent 
phrase implies that this friendship was not even humanly holy. I am confident Augustine never meant that. It is only a part of the contempt which he pours on all things human-love, joy, pleasure, science, art-from the altitude of his new position.

One interesting result of this loss of his friend was that it led to Augustine's first literary experiment. The intensity of his affection, so cruelly revealed, led him to speculate on the nature of the beautiful. 'What is it,' he kept asking his friends, 'that draws us and binds us to the things we love?' After a time he embodied his reflections in a treatise of two or three ("Thou knowest, my God, I forget,' he says, in his familiar way) books 'On the Fit and the Beautiful.' They were dedicated to Hierius, a Syrian rhetorician, who was being much talked of at the time; Augustine has afterwards to devote many pages to the folly of this dedication. It would be interesting to read what he had to say about beauty in his pre-Platonic days, but the books had already disappeared at the time he wrote his Confessions. The earliest genuine works of his, which we have,were written after his conversion; though an immense number of supposititious 
works were ascribed to him until modern times.

It seems to have been about 379 or 380 that he returned to Carthage, and opened a school of rhetoric. With all its gaiety, Carthage was a busy centre of education, and had a feeling for rhetorical display. Augustine would not lack pupils; and, as I have already mentioned, he once gained the crown in the theatre for a prize oration, and won the affection and patronage of the proconsul Vindicianus. Some of his pupils followed him from Thagaste, and they were joined by a clever youth, from the neighbourhood of Carthage, of the name of Nebridius, and a certain Eulogius, who afterwards became himself a rhetorician of some merit. His friend Alypius, who was training for the law (though he eventually found a place with Augustine in the ranks of the episcopate), did not attend his lectures regularly, his father having quarrelled with Augustine. The youth was soon deep in the dissipations of Carthage, it appears, but Augustine one day made a scornful attack on the attractions of the circus at a lecture at which Alypius happened to be present, and the spell of the circenses was broken. From that time Alypius became his most devoted 
admirer-though Augustine had again to rescue him later from the more brutal charms of the amphitheatre.

During the nine years which elapsed between his first contact with Manicheeism and his departure from Africa, Augustine was resolutely advancing towards the heights of his early vision. The enthusiasm of his first acceptance of Manicheeism did not last many years. It was not that his ideas were taking a shape which was incompatible with the materialist conceptions of the system. It was not until five years later, when the translation of certain Neo-Platonic works opened out to him the entirely new world of Pythagorean and Platonist thought, that he began to feel the impropriety of his physical conception of God and the soul. Nor had he yet so definite an idea of the infinite as to perceive the absurdity of admitting two deities, as the Manicheans virtually professed. His real mental growth consisted in an accumulation of disjointed facts and thoughts, the formation of a treasury of knowledge, which could be drawn upon in the later years when reading was no longer possible, and science and profane history were accounted frivolity. But he had no leading thoughts wherewith to order the 
storing of his harvest, and to his last days his erudition, such as it was, remained an uncritical and an undigested mass. ${ }^{1}$

Augustine is really unfortunate in the causes he assigns for his early revolt against the Manichean system. He seems to indicate two chief lines of criticism, when we set aside the destructive analysis he makes of it after he has assimilated Platonic ideas. He alleged 'scientific' difficulties against the Manichean scriptures, and moral difficulties against its elect. After all, we do not change wholly with the ages. But, quite apart from the question of principle, Augustine was not fortunate in many of his points. His liking for divination had induced him to make a close study of astrology and astronomy. From this science he seems to have forged weapons which his Manichean friends could not parry. Their sacred books naturally contained much assertion about the nature and the motions of the heavenly bodies. Augustine says he found a good deal of this to be erroneous, and he began to pose as a scientific heretic. Probably he was right on some points. But it had been better for science if he had penetrated a little deeper into astronomy in his early

${ }^{1}$ So also says Nourisson, in his Philosophie de Saint-Augustin. 
years. $\mathrm{He}$ and other fathers of the Church only succeeded in prolonging throughout the whole of the Middle Ages the life of errors which Manicheeism and Neo-Platonism were beginning to uproot. For instance, he denied against the Manicheans the sphericity of the earth and the existence of the antipodes, as he denied against the Epicureans the plurality of worlds and other truths. Nor can we recognise a more solid grievance against his religion in his complaint that it did not teach the cause of the equinox and the solstice.

There was probably more force, though no better logic, in his quarrel with their morality. The man who nowadays secedes from a Christian Church on such grounds is very justly regarded as wanting in strength of character. One fails to see why Augustine should be so loudly applauded for leaving the Manicheans because he found some corruption amongst its elect. Indeed, in so gentle an age as this, when it is considered dishonourable to unmask the hypocrisy one has left behind for quite other reasons, it is remarkable how much admiration is felt for Augustine's vicious little treatise ' $O n$ the Morals of the Manichees.' The truth is, that even he has little 
accredited scandal to tell of them, however well disposed we may be to accept it. After his nine years' intercourse with them, the only convincing story he tells is that he once saw some elect behaving rather improperly in the open street. The rest is all hearsay, and comes from feminine sources. The Manichean clergy were evidently either much better or much cleverer than the Christian. With regard to the more depraved matters, in fact, Augustine has nothing but strained inferences from their doctrines to offer to his fellow-Christians.

Whenever Augustine related his difficulties to his fellows, he was met with the assurance that a certain bishop of theirs, Faustus of Mileve, would answer them when he came to Carthage. In $3^{8} 3$ the famous bishop came, and Augustine consulted him. The result was a final disillusion. A man of fine carriage and captivating manners, a fluent and eloquent speaker, Faustus had hitherto not felt a pressing need for mere erudition. The type of apologist is familiar to most of us. But Augustine was the obstinate young man, who had definite questions and insisted on having definite answers. 'What availed the utmost neatness of the cupbearer to my thirst for a more precious 
draught?' Faustus knew no science save grammar, and shrank from the young astrologer who was insusceptible to his charms. The episode ended in the almost total collapse of Augustine's belief, but without bitterness. 'He had a heart,' and frankly avowed his ignorance, says Augustine. In fact, he began to read with Augustine, and continued friendly relations with him for some time. But in the later years, when his beliefs have hardened and controversy has somewhat soured the milk of his kindness, Augustine presents his opponent in a less flattering light. He is described (Contra Faustum) as a man of poor parentage, who has made his way by cunning rather than conviction, and who conceals most luxurious habits behind a profession of unworldliness. If the share in the dialogues which is accredited to Faustus correctly represents his words, he was a polished, witty, and acute speaker, but superficial. But where Plato is abused, Faustus must expect little consideration.

Thus, in his twenty-ninth year, Augustine has had his first disillusion. His faith in the Manichean key to the universe was destroyed. He says he still had a feeling that perhaps his difficulties could be removed, but it is apparently a mere 
shadow of hope, transient and intangible. Yet Christianity was as repulsive to him as ever. He vaguely recalls the many philosophies to which Cicero had alluded - if he had not outlined them -in the Hortensius. And with still youthful energy he resumes his Sisyphean task.

But this disillusion seems to have completed a growing burden of discontent with Africa. With the broadening of his mental horizon the distant splendour of Rome began to find a reflection in his thoughts. His friends told him that successful rhetoricians made large fortunes in the eternal city, and that the pupils were better behaved. At Carthage the youths would rush into the lecture-room in the middle of the lecture, and bear away their companions with an intolerable turmoil. He resolved to sail for Rome. Years afterwards his heretical opponents said he had been driven from Africa by the decrees which Messianus, the proconsul, passed against the Manichees. It is true that Augustine still counted himself a Manichean-' not seeing anything better, I resolved to remain where I was until something more eligible appeared'; but the decrees of Messianus were not passed until three years after his departure. 
A detail of his departure, which one would rather suppress, must be noticed. After vainly urging him not to leave Africa, his mother insisted on accompanying him to Rome. We can well understand that the proposal did not please Augustine, and placed him in a difficult situation. But the manner of his escape from it was unpardonable. He persuaded her to spend the night before their departure in a chapel near the quay. During the night he sailed for Ostia. Augustine's frank confession in some measure redeems the meanness and cowardice of his act. 


\section{CHAPTER IV}

\section{THE ETERNAL CITY}

When Augustine came to Rome in 384 he saw almost the last gleam of its ancient splendour. The genius of the eternal city had departed, and, heavy with the ruthless spoils of the world, it was already tottering to its fall. Far away on the northern and north-eastern frontier the stream of Huns and Goths and Vandals was swelling its irresistible flood against the weakening barriers. The vultures gathered thick upon the mountainfringe of the empire. But the Romans were to ' die with a smile on their lips,' as Salvianus afterwards said of them. Augustine found the gold and marble city of three centuries of Cæsars in undiminished splendour, and the life of its infatuated people making its seven hills ring with their demented laughter. $\mathrm{He}$ is almost wholly silent about the scenes he witnessed. Happily, there came to Rome, somewhere about the same 


\section{ST. AUGUSTINE AND HIS AGE}

time, a war-worn veteran from the front, Ammianus Marcellinus. From his scornful pages we can picture to ourselves the life of Rome in the last quarter of the fourth century. ${ }^{1}$

We can almost fancy ourselves lying with a group of Roman citizens in ragged togæ, playing dice, under the cool colonnade of one of the emperors' fora, or the Roman forum, and watching the stream of life as it passes. Rich patricians, with loosely swollen cheeks and thick hanging lips, fly past us in gold-plated chariots, drawn by swift teams of Spanish horses, a dozen tunics and mantles of all but transparent silk fluttering about them. Young dandies, already old in vice and luxury, ride or walk along, their fine mantles shaken out now and again with a wave of the left arm to display the figures embroidered on them, and the silk dragons that hiss in the wind, and the dainty little shoes embroidered with ivy leaves; a secretary-slave walks with them, suggesting to their flaccid memory whom they know and must salute. Roman matrons pass by in litters, or in carriages drawn by four white mules.

1 In the following sketch I have completed, or corrected, the testimony of Ammianus by that of St. Jerome, Symmachus, Claudianus, Prudentius, Paulinus of Nola, Macrobius, and others. 
For woman is no longer confined to the gynecæum. Stoic philosophy and Christian religion have won freedom for her. And now she leans proudly back in her litter, her hair rising into a tower, bristling with points and bars of gold, her eyes dilated with antimony, her eye-lashes and eye-brows dyed, her lips a brilliant and refreshing vermilion-she has been chewing wood to provoke the saliva,-her face and neck coated with white, the price of a forest hanging from her ears, her tunic a stiff mass of cloth of gold; or perhaps she is a Christian, and a crowd of urchins follow, gazing at the wonderful embroideries on her silk mantle, representing the poverty of Christ, and the sorrows of Job, and so forth. Here a widow, or a divorced (perhaps for the tenth time) matron, is borne sedately along, the whole army of her slaves, even to the kitchenslaves, marching before the litter, and a second army, of eunuchs, bringing up the rear. There a pedagogue leads along her children, their shoes made to creak nicely, their hair dyed red, their faces painted like her own. At one moment the sun glitters on the jewelled fingers and buckled and perfumed locks of a Christian priest, and the next it flashes on the painted face and the gay 
tunic of a sexless priest of Cybele or the shaven head and face of a votary of Isis. So the tide ebbs and flows through the Roman forum, and the forum of Trajan- ' the most exquisite structure under heaven,' says Ammianus-and along the via sacra and up the clivus of the Capitol, where the golden roof of the great temple of Jove still flings back the rays of the sun, or past the deserted Palatine to the Circus Maximus, or to the thermæ Antoninianæ (baths of Caracalla), until at last the sun sinks behind the Vatican, and Rome turns to other amusements.

Follow one of the swift chariots with the plates of gold and the flashing gems, until it halts before one of the great senatorial palaces. Gold-dust is, perhaps, strewn on its polished marble steps, for the safety of the nerveless limbs. The chances are that fawning eunuchs must help the senator up the steps and between the tall columns of Parian marble, with gilded capitals, into the vestibule with its silver chairs and couches, its walls incrusted with mosaics and many-coloured African marbles, its ceiling of cedar and silver, its rare trees growing between the rafters, and rare birds nesting in their branches. He is bathed and clothed afresh, and rearranged by his barber and 
tailor. Then he goes to meet his guests, and preside at his vulgar banquet. His nomenclator, or secretary-slave, has arranged the names, reaping a generous harvest from the invited, for gold pieces are often given after the banquet. Then, after the basket of 'appetisers' has gone round, the slaves bring in the fishes and birds that have been brought from the ends of the empire; 'thirty secretaries,' so says Ammianus, standing by with their tabellæand their scales to note the weight of the peacock, or parrot, or pheasant, or whatever it may be, that the obsequious guests are praising. And when they lean back on the couch, clutching their rose-crowned silver cups, hydraulic organs, and 'lyres as large as chariots,' and flutes, make merry music; the perfumed oil in the lamps mingles its intoxication with that of the old Falernian wine; and pretty eastern slaves dance voluptuous dances, and mimes play their lascivious parts, until men and women alike sink into the roses on the floor, and are borne home by their laughing slaves.

Such was the Roman patrician in the fourth century, according to Ammianus. Of the broader political condition of the empire he knew little; of its economic condition, nothing. He knew 


\section{ST. AUGUSTINE AND HIS AGE}

only that the stewards still wrung some five or ten million sesterces annually out of his estates in Gaul and Spain and Africa, and so he could buy the prettiest slaves and finest wines and swiftest racers in Rome, and entertain his fawning clients and successful charioteers, and occasionally give the Roman mob an additional spectacle in the amphitheatre. His library was 'like a tomb.' It was the heyday of barbers, and cooks, and sorcerers, and charioteers. A few years earlier, when the city had been threatened with famine, they had deported from it all its scholars and teachers, but had kept their three thousand singing girls, with their masters and choruses. Macrobius tells a story of one of these patricians, whose slaves had adjusted the folds of his toga with the usual care before he went out. He was passing through a narrow place with an acquaintance, and the latter brushed against him, and disarranged his precious folds. He intrusted the matter to his lawyers at once-lawyers whom you could swear Dickens had copied line for line from the pages of Ammianus. These were the lords of Rome in 380 , when the Goths were moving restlessly along the frontier of the empire; men whose supreme effort was to order a slave three 
hundred stripes if he were a minute late with his service, who could not take a bath without having the planets consulted, who 'thought they had equalled the marches of Alexander' if they drove to see their estates or 'sailed in painted boats from Lake Avernus to Pozzuoli or Cajeta,' and who 'grumbled that they had not been born amongst the Cimmerians if a fly alighted on their silken fringes or a ray of the sun found its way through the awning.'

Nor did Ammianus find much more of the old Roman spirit in the lower classes. Amongst the million or so of people who then dwelt in the I 790 palaces and 46,600 tenement-blocks of the city, there were-apart from the wealthy and their vast following of slaves, parasites, and dependants, and the hereditary corporations of bakers, butchers, etc.-some 200,000 or 300,000 free citizens who subsisted on the public distribution of food. From morning until night they lounged about the fora and the wine-shops, playing dice, and discussing the latest or the next games in the circus. When the hour for the distribution of bread came-later emperors had increased the folly by adding pork and wine and oil-they gathered shamelessly on the 'bread-steps,' where the bronze tablets 
exhibited the roll of honour, and received their rations. Then, perhaps, they earned a little money from some senator or charioteer by promising their support at the next race, and returned to the dice-board, and the wine-cup, and the thickly-clustered fornices down the Subura. At the princely Antoninian baths, where there were marble seats for 1600 bathers, they could steam and bathe themselves, exercise in the palæstra, and lounge in the peristyle, for a farthing. Perhaps it was a day of religious feasting, and they flocked to the templesChristian as well as pagan-and gorged themselves with food, and reeled with intoxication, in honour of any god or goddess that chanced to have wealthy admirers. Or it may have been one of the 175 days of public games, or the day of a special feast given by some rich senator; Symmachus spent $£ 90,000$ on the games he provided to celebrate the prætorship of his sonbringing dogs from Scotland (a rare treat), horses from Spain, lions from Africa, gladiators from Saxony, tigers, elephants, comedians, and so forth, from all parts of the world. Those were the days when life ran swiftly in Rome. Rising from almost sleepless beds in some upper story in 
the Subura, they would rush to the Circus Maximus at early dawn, and discuss the prospects of the greens and the blues (the great circus factions of the fourth century) with a frenzy that bordered on madness. And when at length the presiding magistrate dropped the napkin, and the chariots shot along the course, the 380,000 spectators could not have been distracted from the momentous issue for one of the rival factions if the Goths had appeared at the gate of the circus. The following day they would pour into the great amphitheatre (Colosseum), and its silken awnings would swell hour after hour with the roar of 90,000 voices, as the blood of man and beast thickened the sands of the arena; the magistrates, the pontiffs, and the Vestal Virgins smiling approval from the podium. These were the men before whom prefects of the city trembled, when the corn-ships from Africa were delayed, or the wine ran short, or the insolence of some favourite charioteer or gladiator forced the prefects to arrest him. These were the men who could no longer lift a Roman shield, and who mutilated themselves to avoid military service when they were not exempted from it. And the vultures saw, and gathered thicker on the hills. 
That is the picture of Roman life which we find in the caustic pages of Ammianus and the vivid letters of St. Jerome. St. Ambrose confirms much of it in his sermons; he even speaks of matrons reeling out of palaces, at the close of the banquets, into the brilliantly lighted streets. St. Augustine's picture of life in Africa is in full agreement. St. Chrysostom's picture of life at Christian Constantinople is somewhat more repulsive. And so the world talks freely of the unutterable vice of Rome, and finds no mystery in its fall. The world is wrong. That the corruption of Rome, for several centuries dissolving the physical and moral vigour of the race, aided the process of destruction, is beyond question; but one might as well say that Christian Spain has fallen for its sins as make that affirmation of the Roman empire. Modern historians find only too sufficient reasons for the fall of Rome without weighing transcendental theories about the consequence of its vices-the incessant war, foreign and domestic, of the third and fourth centuries; the division of the empire ; the extinction of the agricultural population from which the army had been recruited; the expensive employment of mercenaries; the instruction of the barbarian in 
the art of war ; the stupid fiscal policy, eternally grasping and ruining, never fostering; the pauperisation and degradation of the people of the capitals ; the quarrels and intrigues of rival religions; the decay of patriotism, partly through the debauching generosity of timid emperors and ambitious officers, partly through the effect of Christian teaching on some of the best spirits of the time; the utter demoralisation, in the trail of imperial expansion, of the old Roman religion. It was not so much a change in her morals as in her whole political and economic system that Rome needed, if she were to resist the encroaching tide of barbarians. In the year 384 such a change was beyond the power of a miracle.

The truth is that those who talk thus of the unutterable vice of Rome usually shrink from a careful study of vice in any age. ${ }^{1}$ In reality Rome had made considerable moral advance in the fourth century. To form a picture of Roman life solely from the pages of Ammianus and St. Jerome, as so many do, is as reasonable and just as it would be to judge modern France on the

1 For an instance of the confusion of mind in which historians of a certain type view the vices of Rome and connect them with its fall the reader may study Mr. Sheppard's Fall of Rome, p. 80, and such works as those of Villemain, Ozanam, Döllinger, etc. 
sole testimony of Zola's novels and Nordau's criticisms. Ammianus felt the scorn of a hardened warrior for the luxury of Rome ; indeed, it is suspected that his indignation is fed by some personal grievance. St. Jerome is as safe a guide to other people's morals as we found St. Augustine to be on his own earlier years. Yet Mr. Dill contends that even the picture they give us is no worse than one could truthfully give of English society in the reigns of George Ir. and George III. ${ }^{1}$ Boissier thinks the time recalls the age of Trajan and Antonine.

In the first place, it must be observed that a great change had taken place in the condition of woman, the child, and the slave. I have already indicated that the paterfamilias had ceased to exercise a despotic authority in the home. Woman, it is true, had largely abused her new liberty - though there were fine 'pagan' women, of the type of the wife of Prætextatus, as well as refined Christian women, at Rome in 384; but, regarded in principle, the change argued an important ethical modification in the Roman mind. The Duc de Broglie has generously recognised

1 Roman Society in the last Century of the Western Empire, p. 1.23. 
this outcome of Stoic influence. M. Thamin ${ }^{1}$ has even entitled one of his chapters 'The Christianity of Paganism,' in view of the gradual permeation of pagan thought with elevated Stoic principles. The facility for divorce had been greatly restricted (in 331), though the law was still too lax; but when Jerome speaks of the marriage of a man who had buried twenty wives to a woman who had had twenty-two husbands, we are justified in questioning the correctness of his information-or of the 'marriages.' There was a remarkable change taking place in the attitude of the cultured pagan towards the slave. The Saturnalia of Macrobius consists of a series of conversations attributed to a group of the leading pagan senators of the last quarter of the fourth century. In one of these discussions the question of the slave is introduced, and almost all the speakers are credited with most humane sentiments in his regard; nor is there any question here of Christian influence. The days were long since passed when a master could cast a slave into his piscina to feed his precious fishes, or crucify him for disobedience.

In fact, this same Macrobius, writing towards 1 St. Ambroise et la morale Chrétienne. 
the close of the fourth century, gives us quite a new picture of Roman life. M. A. Thierry, in his Life of St. Ferome, contends that 'the second half of the fourth century was undoubtedly the epoch of greatest luxury at Rome and in Italy.' The picture which Macrobius gives us in the third book of the Saturnalia completely disproves this. Here we have a group of Roman senators of the highest rank discussing 'the luxury of the ancients' as something quite unknown to their own age. O. Muller, in his exhaustive study De genio, luxu, et moribus avi Theodosiani, remarks that the only reason is because they have less money than the patricians of the first century. I do not think that is a candid interpretation of Macrobius. He speaks, not with regret, but with polite censure, of the days when senators watered their trees with wine, paid vast sums of money for rare fish, dined off peacocks' eggs and larks' tongues, and resorted to devices of gluttony which are too repulsive to dwell upon; 'nunc pretia hæc insana nescimus.' He even speaks of the practice of introducing dancing girls into the banquet-room as extinct; though we know that in this he cannot have been speaking for the whole of Rome. We are bound to oppose Macrobius to Ammianus. 
But, further, we have a more direct knowledge of this better side of the dying Rome than the imaginary discourses of the Saturnalia. The leading characters of that work are historical personages. The host, Vettius Agorius Prætextatus, with his friends Symmachus and Flavianus, formed the centre of a group of patricians who do much to redeem the vulgarity depicted in the more frequently quoted Ammianus. The letters of Symmachus, prefect of the city in 384 , introduce us to a world into which the soldier-critic had evidently not penetrated, a world of serious, refined, cultured, and temperate Roman senators, who command respect. Symmachus was the most distinguished letter-writer in that age of epistolary art. His brief but elaborately-wrought epistles were read to admiring crowds of Romans. There were even those who engaged thieves to intercept the slaves who conveyed them. We have a large collection, in ten books, of these letters; and, though they are surprisingly disappointing in respect of the historical information they afford us, they do, nevertheless, reveal the existence of a body of patricians of admirable type. In some instances, as in the case of Prætextatus, sometime proconsul of Achaia and prefect of Rome, we know that the 


\section{ST. AUGUSTINE AND HIS AGE}

wife was no less worthy, and no less sincerely devoted to the old Roman religion, than the husband. These men were probably less rich than the Romans we have described above. The income of men like Symmachus - who had three houses in Rome and fifteen villas in various parts of Italy-is estimated to have been about $£ 60,000$ per year; the income of the richer Romans of the time is said to have reached about $£$ I 80,000 per year. But such as their wealth was, they made a sober and unselfish use of it, and were proud to exhibit the finer ideal of ancient Rome, purged of many of its defects, in the closing years of the empire. Unhappily, even these reveal no sense of the dangers that menace the empire. If we may trust the poet Claudianus, such apprehension as was felt was directed, in strange perversity, towards distant Persia. To their real dangers they seem quite insensible. We can only say, firstly, that the removal of power from Rome almost removed responsibility from the senators; and, secondly, that they were involved in a struggle for the maintenance of a religion which they thought essential to the life of the empire.

Thus, when we set Macrobius against Ammianus, and Symmachus against Jerome-I would 
add, if it did not go beyond our period, Ausonius against Salvianus-we obtain a truer and fuller impression of the life of Rome. If the paint and tinsel and vulgarity and passion were all in that life, there would be some ground for the edifying phrases of the ecclesiastical historian. But pagan Rome-Christian Rome I reserve for the next chapter-was far from being wholly corrupt. There is hardly a trait in the darker picture which has not its counterpart in modern life. With one exception; we have, happily, nothing to correspond to the quarter of a million of stout frames that were rotting in idleness in imperial Rome, consuming in a life of heartless and senseless pleasure the blood and sinews of the empire, which they thought they could prey on for ever. Nature reminded them that social life has its laws, moral, political, and economic. ${ }^{1}$

1 As to what we call immorality in the narrower sense, I will be so bold as to make a brief comparison with modern times. The phrases one meets about the 'nameless vices' of Rome have misled many into thinking there were practices then in vogue which are happily unknown to the modern world. Taking the unnatural forms of vice as they are enumerated in Rosenbaum's Geschichte der Lustseuche, any person of moderate information in these matters will recognise that all of them are appallingly prevalent in modern Europe; indeed, some of the most repulsive of them are more prevalent to-day than we have any definite reason for thinking they were at Rome in the fourth century. As to forms of vice which 


\section{ST. AUGUSTINE AND HIS AGE}

are not physiologically unnatural, it would be idle to question the general absence of moral restraint in the fourth century. But it is open to question if Rome had as high a proportion of lupanaria, and offered as flagrant an advertisement of vice, as modern London; and it is certain that adultery (in the complete sense) was infinitely less prevalent (witness the prosecutions of 368 ), and the exhibition of obscenity permitted by public authority was no worse, than in modern Paris. 


\section{CHAPTER V}

THE OLD GODS AND THE NEW

IN the year that Augustine came to Rome there was unusual excitement in the eternal city. Christianity had opened in earnest its legislative war upon the old religion. The long peace that had endured since the death of Julian had been broken by a severe blow at the prestige of paganism. Gratian had been induced to confiscate the revenues of the temples, and to annul the civic and political privileges of the pontiffs and the vestal virgins. This was in 382 ; Gratian was betrayed and slain in the following year. But when the pagan chiefs approached the boyemperor, his successor, it was only to receive a resolute confirmation of the decree. Augustine came to Rome in the midst of the profound agitation which was caused by this change in the imperial policy.

In a bucolic poem which seems to have been 
written about this time by a Christian, known as 'Endelechius,' it is stated that 'the Christian God alone is worshipped in the towns.' That is obviously intended to impress the ignorant rustics, but it is an utterly untrue statement. Augustine left a city which was predominantly pagan for one which was still violently, if not profoundly, attached to the old religion. Four hundred temples, many of them magnificent museums of sculpture, paintings, jewellery, etc., still opened their doors to the worshippers. The great temple of Jupiter, with its golden gates and golden roof, still crowned the Capitol. The gilded statue of Victory, the colossal statue of Apollo, and hundreds of others, surrounded the Forum. Through all the squares, at all the cross-roads, over the fountains, baths, arches, and public buildings, the marble images of gods and goddesses were still enthroned. Over every door was the tutelary image, before which even the Christians timidly lit their lamps at night, pretending, says the scornful Jerome, that they were merely lighting the entrance. The obelisk in the Circus still marked the dedication of their chief temple- 'their only temple,' growls Ammianus-to the sun. The games were still chiefly connected with the festivals 
of the gods. The Saturnalia still offered their prolonged dissipation. On the Lupercalia (in February) the priests of Pan still ran about the streets in their goat-skin cloths, and unblushing matrons met the blows of their whips. In March the priests of Cybele descended from the Palatine for the great festival of 'the mother of the gods.' Augustine describes how he saw them in the wild licence of their 'Easter Sunday,' which closed their 'Holy Week' of lamentation; when they took the black stone, covered with a silver female head, which represented the goddess, for the solemn bath in the Almo, and returned through Rome in an orgie of rejoicing, the drums and horns and howls throwing the priests into a perfect madness; though Rome had forbidden the excesses they practised in the East, where they mutilated themselves in the procession, and carried the bloody emblem before them. In June the meretrices still celebrated the licentious Floralia in the streets. The priests of Mars still danced and sang their old Latin songs on the public roads. The smoke of the sacrifices had not ceased, for there was still a certain source of revenue-the vectigalia templorum, a fund instituted to pay for the sacred banquets and games-besides private devotion. 


\section{ST. AUGUSTINE AND HIS AGE}

People still slept on the skins of the sacrificed animals in the temple of Æsculapius for the purpose of learning the future; matrons still sat on the emblem of Priapus to ensure fertility ; men, women, and children still hung their ex-votos in the temples, and consulted the astrologers and sorcerers as to every step they took. They still had a god or a goddess for every leaf or every muscle. Augustine describes eleven deities who presided over the growth of corn. They had not only the guardian image over each door, but they had a god of the door, Forculus, with subsidiary deities for the threshold and the hinges, Limentinus and Cardea. Human life was guarded by a stupendous army of deities. To pass over the functions of Mena, Virginiensis, Subigus, Prema, Pertunda, Venus, and Priapus, there were Lucina to preside at the birth, Opis to receive the child, Vaticanus to open its mouth, Levana to lift it up, Cunina to watch the cradle, and Rumina, Potina, Educa, Parentia, and a hundred others. Religion was not a matter to fill up the idle hours of a Sunday with the Romans; such as it was, it was co-extensive with life.

Further, there were religions in Rome which were as earnest and strenuous as Christianity. 


\section{THE OLD GODS AND THE NEW}

Renan has puzzled many people by saying that if the progress of Christianity had been arrested by some moral miracle in the fourth century, Mithraism might have become the religion of the west ; most people being under the fond impression that they know nothing about Mithraism. It is impossible to discuss here what probability there was of Mithraism absorbing Christianity instead of Christianity absorbing Mithraism ; ${ }^{1}$ but in the fourth century the Persian cult attracted some of the most religious and most cultured minds in Rome. The Christian prefect Gracchus had destroyed one of their temples on the Vatican in 376 , but we have inscriptions recording sacrifices in their temples (for the purpose of baptism, the devotee standing below in the stream of blood) by some of the leading patricians until near the close of the century. The elaborate ritual which was carried out in the underground temple, the religious gloom alternating with the brilliance of lamps and candles, the perfume of flowers and incense, the symbolic theology, the dramatic representation of the birth (on the $25^{\text {th }}$ of December), and the rock-burial and

1 See Mr. J. M. Robertson's able and conscientious study, Christianity and Mythology. 


\section{2}

\section{ST. AUGUSTINE AND HIS AGE}

resurrection (in spring) of the Saviour, the allpervading idea of regeneration, and the ascetic standard of life, appealed no less strongly than Christianity to some of the better Romans. Modern writers attribute to Mithraism and the worship of Isis, which had also found favour at Rome, the inspiration of a deep and uplifting religious fervour in the last decades of the fourth century. The fathers were greatly troubled at times both by the moral power and the similarity of dogma of these new cults; but in an age when Plato was believed to have taken lessons from Jeremiah, and the devil accommodatingly acted as an angel of light sometimes, the difficulty was not insuperable. However, Mithraism spread far and wide through the empire. If indeed Constantine had chanced to stake his fortune on Mithra instead of Jesus in his decisive battle, it is difficult to say what might have happened.

Finally, we must not forget the sect to which Augustine himself still nominally belonged. $\mathrm{He}$ has not presented it to us in attractive colours, it is true ; but there is a passage in Jerome (ep. 22, written in 384) which, considering the fewness of the Manicheans at Rome owing to persecution, should greatly moderate our impression. After a 
most bitter and sombre dissertation on the morals of the Christian women at Rome, he confesses that when people meet a woman of severe deportment and pallid features (Jerome's ideal of a woman) in the streets, they at once class her as a Manichee.

In this rivalry of religions Christianity had already taken up a formidable position since it had been adopted at court. In 374 there entered into the hierarchy, at the very point where it came into closest contact with the court, an able statesman and devoted and commanding ecclesiastic. By 384 the influence of St. Ambrose, so strangely underrated by historians as a rule, ${ }^{1}$ had made a deep impression, and paganism began its rapid decline. When the superstitious Constantine cast about for a deity who was not already secured by his adversary in the struggle for empire in 323 , it occurred to him to try the power of the Christian God, for whom his father had entertained some respect. He won, and Christianity became the religion of the court. Constantine, Constans, and Constantius, whatever their personal feeling, and apart from a few decrees which

1 But compare the emphatic position of De Broglie in his L'Église et L'Empire Romain, vol. v. 
were not enforced, maintained a political neutrality in the religious controversy. Julian strove to eliminate Christianity by all the means which he thought compatible with an ideal of political equality. Jovian and Valentinian maintained the policy of Julian's predecessors. An ancient writer has said that the pagans regained the lost ground under Valentinian; we may follow Ammianus, who says that 'he remained neutral amidst the religious differences.' But with the death of Valentinian quite a new era began, an era in which the supreme power is in the hands of boys and youths, and the Western Church at length receives the man who can turn the situation to account. The year before Gratian, a religious youth of sixteen, mounted the throne, St. Ambrose passed from the bar and the service of the state to the see of Milan, where the Christian court generally resided. Gratian appointed Theodosius, a fervent Christian, to the empire of the East, and there the task of destroying the old religion proceeded with vigour. The West was ruled by Gratian (a boy of sixteen) and Valentinian II. (an infant of four or five). 
Both Gratian and Valentinian were at once taken under the spiritual guidance of Ambrose. The panegyrics he delivered over them are inspired by a warm personal affection, and he addresses them in his letters with a familiarity which is leagues removed from the respect of a Symmachus. In fact, he himself says in a letter to Gratian (ep. II.), 'Thou hast gratified me by restoring peace to the Church and shutting the mouths of its enemies.' When, therefore, we find the change of policy, we may at once recognise the hand of Ambrose, as well as the suggestion of Bishop Damasus. In the first year of his reign a decree was issued in Gratian's name which breathed the tolerant spirit of his predecessors. Then, at a date which it is difficult to determine, came his refusal to bear the robe and the title of Pontifex Maximus, which no other Christian emperor had refused. ${ }^{1}$ But in 382 the process of destruction began in earnest.

1 Gibbon, vol. iii. p. 408, puts this immediately after Gratian's accession, as Zosimus seems to intimate, and is corrected by his sage commentators, Milman and Smith. But Herr Schultze, Mr. Dill, and other recent writers, show that there is no solid reason for departing from the natural interpretation of Zosimus. If we must have our Gibbon served up with an abundance of ecclesiastical sauce, 
Gratian issued a decree in which he confiscated to the treasury the estates of the temples, and revoked all the privileges of the pontiffs and vestal virgins. The Catholic historian, who is so full of the iniquity of the Reformers in confiscating the estates of his Church, will appreciate the gravity of this blow; and the loss of civic and political prestige was no less serious. But it was immediately followed by a blow which was even more painful to the pagans of Rome. In the senate-house, on the south side of the Forum, was an altar bearing a beautiful marble statue of Victory, before which the senators swore allegiance to the emperor, and burned incense at the commencement of their deliberations. Although it was only a shadow of power that remained to the senate in the fourth century, the goddess who had presided over the counsels of the state for four centuries was instinctively connected with the very fate of the empire in the minds of the Conservative party. But the senate had been greatly enlarged, and even some of the historic families had passed over to the new religion in the train of Constantine. Whether it is at least time there was an improvement in its quality, and such 'corrections' as this, vilificatory comments from Villemain, etc., were dropped. 
it was true or no ${ }^{1}$ that, as Ambrose claimed, the majority of the senators were Christians in 382 , there was certainly a large party of nominal Christians in the curia. Bishop Damasus, a clever and ambitious prelate, suggested to Ambrose that the altar weighed on the consciences of the Christian senators, and Gratian ordered its removal. It was in vain that the pagans sent their great orator Symmachus to Milan to plead their cause ; Symmachus was ordered back to Rome without being admitted to the palace. In the following year, $3^{8} 3$, Gratian was foully murdered-clearly the hand of Jupiter-and the young Valentinian ruled the western empire.

In 384 , the year of Augustine's residence at Rome, a second attempt was made to obtain the restoration of the statue. The political situation seemed to favour the pagan cause, as the usurper Maximus held an uncertain sword over the head of the young Valentinian. However, the senate dare not risk a second humiliation. Symmachus wrote an eloquent oration, and forwarded it to Milan. According to Ambrose's version of the

1 I will only point out an apparently unnoticed passage in the Confessions (viii. 2), where Augustine says that 'nearly the whole nobility of Rome' was pagan in the time of Valentinian II. 
matter, which is usually followed by the trustful hagiographers, the proceedings were very edifying. The prefect's paper was read before the consistory at Milan. The councillors, mostly Arian Christians, though there were two 'barbarian' generals, were unanimously in favour of restoring the statue. Then the young emperor (aetat. I 4) boldly declared that he would do nothing of the kind, and dismissed the petition unanswered. The truth is that we must insert between the meeting of the consistory and the emperor's decision the remarkable letter of St. Ambrose, which is the seventeenth in Migne's collection. De Broglie thinks the senate chose an occasion when Ambrose was absent on a mission to Maximus in Gaul. In any case, the petition was introduced without his knowledge, but-no one was better informed on the affairs of the curia than Ambrose-he heard of it and of the attitude of the consistory, and at once wrote a strong letter to Valentinian, threatening him with excommunication if he restored the altar. 'Don't let anybody impose on thy youth,' he says to the boy, with delightful consistency; in military matters he may consult military men, but in religious matters the decision must rest 
with religious men. He politically reminds him of the views of Theodosius, on whom his throne then really depended. Finally, he says : 'If it is decided otherwise, we bishops will certainly not suffer it in silence. You may go to church, but you will find no priest there, or else one who will repel you.' He demands a copy of the petition. Valentinian dismissed the petition, and Ambrose published a severe criticism of the oration of Symmachus. To say the truth, that was not difficult, since the tolerance and detachment from details of these cultured monotheistic pagans placed them at a great polemical disadvantage in comparison with the fervent exclusivism of Ambrose and his colleagues. Indeed, there was a profound truth on the side of the Church, which Ambrose ably developed in his reply, and which is, unhappily, too little appreciated by his modern admirers. It was the truth-obvious enough to us (when there is question of its application to past ages)-that humanity makes progress. Be it God, or nature, or the world-soul that grows through the ages, that inspires those views of man's life and destiny which we call religions, this much is certain - they improve from age to age. Not the conservatism for 
which Symmachus pleaded so eloquently, but progress from religion to religion, is the great lesson of history. Christianity had the germs of great evils in it-a glance down the Middle Ages suffices to justify the phrase-but it was morally and intellectually far superior to the religion which it sought to replace. Symmachus and his colleagues were resisting the sternest and the happiest law of this perplexing world.

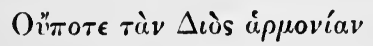

$\theta \nu a \tau \hat{\omega} \nu \nu \pi \rho \in \xi \xi a \sigma \iota \beta o v \lambda \alpha i$.

This year 384 decisively marks the downfall of paganism. Feeble attempts were made to renew the petition, but they met with no success. Towards the close of the year, Prætextatus, the most respected figure in the conservative body, died. The Romans left the theatre in tears when the death was announced in the middle of a performance; St. Jerome hastened to assure his patrician friends that Prætextatus had gone 'to Tartarus.' Symmachus retired from public life in despair. Flavianus led a courageous revolt under Eugenius in 392 ; there was another revival under Attalus in 409. These were momentary eddies in an irresistible stream. There were devoted pagans in office even after 
the fall, but the process of dissolution set in rapidly at Rome in 384 . The decree of 382 was only the prelude to a long series of enactments, mostly traceable to episcopal influence, which consummated the work. Pagan beliefs were not of the kind that thrive by persecution.

Augustine maintains a significant silence in the Confessions about the great events he witnessed at Rome in 384 . He tells us two things only: firstly, he was less drawn to Christianity than ever ; and secondly, he felt an inclination to turn his back on all the churches and temples. We can easily fill in the eloquent blank in his experiences, if we examine the situation of the Church at Rome during his residence there; and the brief study will help us to understand to an extent why, apart from the struggle over the new law, the cultured pagans of the time politely ignore the existence of Christianity in Rome.

If Augustine was at Rome in the month of November 384, he probably went with 'all Rome' to see the funeral of Blesilla, daughter of a noble Christian house. Her remains were being conveyed with exceptional pomp to the tomb of her ancestors, when her mother Paula gave way to a wild burst of grief, and was carried 


\section{ST. AUGUSTINE AND HIS AGE}

away insensible. Instantly, a roar of anger went up from the crowd. "She is weeping for her daughter who has killed herself by fasting. Why aren't those wretched monks driven from the city? Why aren't they stoned, or flung into the Tiber ?' And if Augustine had asked the meaning of it all, he would have heard that a certain fanatical monk, of the name of Eusebius Hieronymus, a savage Pannonian or Dalmatian, had a school, in the palace of Marcella up on the Aventine, where he taught these suicidal doctrines to a group of women. On further inquiry-for the name monk would be new to him-he would learn this curious story. When Athanasius came to Rome in 34I he brought with him two monks, who attracted as much attention as Symmachus's Scotch dogs. They moved freely amongst the wealthy Christians, telling the marvellous story of the Egyptian desert. There were several Christian palaces. The great house of the Probi had loyally imitated the emperor's example immediately after his victory, and others had followed. The monastic idea appealed to the ladies of these families; we do not, unfortunately, find any indication of masculine fervour in them until late in the century. In the course of time 
a noble lady, Melania, caused intense excitement by selling her property and departing for the East. Then another, Marcella, founded a kind of spiritual home in her palace on the Aventine, and a group of Christian ladies-Asella, Furia, Fabiola, Marcellina, Felicitas, Paula, Eustochium, Blesilla, Lea, etc.-gathered there for devotions and the cultivation of a lofty ideal of life. The palace of the Anicii, the heiress of which had married Sextus P. Probus, was another great Christian centre. From these two palaces streams of gold flowed out over the whole Christian world. Much of it stopped in Rome. Pope Damasus flew about in a splendid chariot, and gave banquets equal to the emperor's, says Ammianus. Under the arcades of St. Peter's on the Vatican liberal rations were served out to poor Christians. The Church expanded.

About 380 there came into the hands of the community on the Aventine a letter from a young monk of the Syrian desert, who had studied in Rome and lived there-more pleasantly than piously-some years before. The letter delighted them so much that they learned it by heart. The writer, St. Jerome, was urging a friend to join him in the desert. It made contemptuous refer- 


\section{ST. AUGUSTINE AND HIS AGE}

ence to 'that fool Plato,' and it had one passage of dramatic force. 'Though thy little nephew cling to thy neck,' the young saint cried; ' though thy mother loose her hair and rend her garments and show thee the breasts thou hast sucked; though thy father cast himself down on the threshold; tread over him, and go forth with tearless eyes to the standard of the cross. In these things cruelty alone is true piety.' These things were committed to memory by young daughters of patrician houses. In 382 Jerome returned to Rome, and at once became the centre of the group on the Aventine. He directed them in the study of Hebrew and the Scriptures, and wrote them numbers of violent and not very refined letters, which represent the Roman community in a most uncomplimentary light. But the Church grew. Jerome may be regarded as the father of the finer art of proselytising, which is still so fruitfully cultivated at Rome; such is the advantage of hourly intercourse with the gentler sex. Giving instructions to Laeta (ep. 107) on the education of her child, at a later date, he directs her to use her daughter in the task of converting her father, Albinus, an eminent patrician and pontiff: 'When she sees her grand- 


\section{THE OLD GODS AND THE NEW 105}

father, let her climb his knees, and clasp her hands about his neck, and force him to listen to her prayers.'

Albinus was converted, but after a long struggle. Jerome favoured mixed marriages (which Ambrose opposed), and the claims of Christianity were soon being pressed in every palace with that gentle and tactful zeal which the Church has ever recognised in woman. But we can well understand the hesitation of cultured Romans to admit them. Neo-Platonic philosophy and Stoic morality had prepared the way to a great extent, as we shall see in the conversion of Augustine and others, but there were intellectual and moral difficulties in the Scriptures themselves, and especially in this ascetic development of Christian principles. We can guess the feelings of a Roman father when he heard his daughter repeating Jerome's words to Heliodorus (given above), or his advice to Laeta, or his opinion that 'adult virgins' should never take a bath (ep. 107), or his contempt of Plato, or his praise of the young girl who sold her jewellery without her parents' consent (ep. 24), or his sneering concession that ' marriage was all very well for those who were afraid to sleep alone at night' (ep. 50), or his declaration to the widow 


\section{ST. AUGUSTINE AND HIS AGE}

Furia that to marry a second time for the sake of maintenance was 'to prostitute her chastity like a harlot,' or his coarse and fanatical insistence on the treasure of virginity- ' which,' Jerome candidly tells his friends, "I do not praise to the sky because I possess it, but rather because I admire what I do not possess.' At a time when depopulation was one of the greatest evils of the empire, thoughtful Romans were little disposed to listen to the morbid praise of virginity which was taken up by every great prelate in the Church; they did not feel reassured by Ambrose's theory that God would increase the fertility of their matrons in recompense, or Chrysostom's notion that the race would be propagated miraculously. ${ }^{1}$ Moreover, even senators, like Paulinus, were beginning to desert the service of their country under the influence of this religion of detachment, as Jerome (ep. 145) urged even the soldiers to do.

On the other hand, Jerome's letters made it clear that, whilst these efforts were being made to instil heroic enterprise into women, the clergy were sinking deeper into corruption. Chrysostom said of Christian Antioch that 'amongst so many

1 The Manicheans used to retort to the Christians: 'The mule is a virgin.' 
thousand men there were not a hundred who would be saved, and he had a doubt about even these.' That seems to have been Jerome's idea of Rome. Outside of his select school on the Aventine, he sees nothing but corruption. Grossly, and in gross phrases, he repeatedly assures his lady pupils that the priests and Christian women of Rome are deeply corrupt. Pope Damasus, almost his only friend, he loyally defends; but there is no reason to doubt either the sanguinary struggle and intrigue which preceded his election or the luxurious life that followed it, as stated by Ammianus. Ozanam points out that ' not a single great man filled the see of Rome in the first four centuries'; Villemain unkindly remarks that the Church of Rome did not even produce a heretic. ${ }^{1}$ And if Damasus was himself a matronarum auriscalpius, as rival priests said, it is hardly surprising that the frailty was very conspicuous in his clergy. The imperial authorities had to pass a law (in 370), which was read in the churches, making invalid any legacy to the Christian clergy. 'I don't

1 In which affirmation Villemain himself is not above suspicion. For Helvidius and Jovinianus, Jerome's great enemies, strongly attacked the virginity ideal, the growing cult of the Virgin, the use of pagan ritual and practices, and so forth. Jovinian succeeded in persuading several nuns at Rome that the married state was quite as holy as virginity, and more comfortable. 


\section{ST. AUGUSTINE AND HIS AGE}

complain of the law,' says Jerome (ep. $5^{2}$ ), 'but I grieve to admit we have deserved it.' ${ }^{1} \mathrm{He}$ describes the priest or the deacon rising early, dressing with care, and setting out, his fingers glittering with rings, his hair curled, perfumed, and buckled back, to spend the whole day in visiting wealthy Christians. Elderly people without children are his chief spiritual concern. In other houses of the rich he is eloquent with admiration of some fine cushion, or other object of luxury, until it is given to him. There are graver matters. Elderly widows attach these handsome young priests to themselves, at first as spiritual advisers; priests have young women serving and living in their homes, who are wives in all but the name (ep. 1 25). Jerome warns the young Eustochium (ep. 22) that most of the 'virgins' about her are hypocrites, and most of the priests seducers; many of them only seek ordination, he tells her, that they may have freer access to women. Jerome had, of course, to pay for his candour. $\mathrm{He}$ was accused (unjustly) of being more than a spiritual director to Paula;

1 To illustrate the precariousness of human testimony, compare the words of Ambrose on this point: 'Although no fault can be assigned, we are oppressed by law' (Resp. ad Symmachum). 


\section{THE OLD GODS AND THE NEW 109}

Damasus was long under a similar imputation. In a word, we cannot affect to be surprised that the cultured pagans of Rome ignore the existence of Christianity. They very rarely show hostile feeling, in spite of their defeat, but it is not a serious religious phenomenon to them, as such. It has been said that, in the condition of the Roman empire, an extreme of asceticism was the proper and effective ideal to set up. The study of this group of cultured pagans on the one hand, and of the hypocrisy of the clergy on the other, shows the utter futility of this statement.

Amongst the lower orders Christianity met less resistance, or at least a resistance which was more easily turned. Showy processions, sacred banquets, and sacred games were the only indispensable features of the old religion. The Church generously smoothed the path to the new temples as much as possible. It not only counselled the liberation of slaves and the giving of alms, but it acted with policy and discretion in other ways. It admitted sacred banquets in the churches until late in the fourth, and in some places late in the fifth, century. Merchants set up their stalls about the church, a kind of fair was instituted, and there was heavy drinking, dancing, and panto- 


\section{I10 ST. AUGUSTINE AND HIS AGE}

mimic performances all day long; as long as the supply of cakes and wine was generous, the worshippers would not mind whether the feast was before an altar of Bacchus or over the bones of St. Peter. St. Ambrose and St. Augustine, as well as a number of councils, fought strenuously against these fearful abuses. The games were a source of trouble for many years. For the higher classes it was in the schools that Jupiter took refuge when the temples were closed; for the lower, it was the circus and the amphitheatre. But the gladiatorial contests were eventually suppressed ${ }^{1}$ though it was by no means so simple a matter as the current story of Monk Telemachus represents -and it was shown that the chariot races, etc., suffered little by the omission of the religious element. As to the processions and manner of worship in general, the Church was very accommodating. The Saturnalia became Christmas and its succeeding festivals. The purification of Isis became the purification of Mary; the Floralia, Pentecost; and so on. Hymns to Cybele were hastily adapted to the mother of Christ; statues of Isis and Horus became Mary and Jesus. Stately processions once more made their way to

1 And suppressed by the Church, be it noted. 
the temples, now converted into Christian churches. Lanciani says ${ }^{1}$ that many pagan altars were in use in Roman churches until a century ago; that the standards of weight were transferred to the Christian Churches, and became the stones that killed St. Stephen and other martyrs; that Christian churches of the fifth century even copied the pagan custom of having baths attached for the convenience of the worshippers. People hung up their crutches and ex-votos to the saints as they had done to Juno and Æsculapius. They had the incense, and the music, and the flowers, and candles, and vestments, and holy water, just as in the good old times. 'Nothing distinguishes you from the pagans,' said Faustus to St. Augustine, 'except that you hold separate assemblies;' that was much more true in Italy, after the close of the temples in $39 \mathrm{I}$.

I have thought it of interest to describe at some length the ferment of religious activity into which Augustine came at Rome in 384. That he was untouched by the temptations of Rome he is forced, somewhat reluctantly, to allow; he can only say that ' $m y$ sin was the more incurable as I thought I was committing no sin.' He was

1 Pagan and Christian Rome, chap. i. 


\section{ST. AUGUSTINE AND HIS AGE}

faithful to the mother of his son, Adeodatus, then a boy of eleven or twelve years. But the intellectual effect of Augustine's short stay at Rome was very great. He began to weary of his Sisyphean task, and look with favour on the academic teaching. 'I had an idea that the philosophers who go by the name of the Academics were wiser than the rest, in that they said we should doubt about everything, and the pursuit of truth was hopeless.' We must take his statement with some reserve; he never really learned much about the Academics (who were thorough Agnostics), and never doubted the existence of God. In his De Utilitate Credendi he says that when 'the great waves of his thoughts inclined him to the academic philosophy,' he was arrested by the power of the human mind; that remains throughout life the chief basis of his spiritualism. He then felt that a divine authority must have indicated some path across the despairing plains of life to the golden peaks of his Ciceronian dream. But immediately, he says, "the forest of the conflicting sects' arose before him, and repelled him once more. He despaired of finding the truth in the Church; paganism he never deigns to mention. He preferred to remain a nominal 


\section{THE OLD GODS AND THE NEW II3}

Manichean, but he says emphatically the connection was no more than nominal. Every path to the alluring hills seems closed. He forgets, or is ignorant of, the Neo-Platonic religion and philosophy; and he plunges sadly into the commonplace work of life. 


\section{I4 ST. AUGUSTINE AND HIS AGE}

\section{CHAPTER VI}

\section{LIGHT FROM THE EAST}

Augustine had a private school of rhetoric during the few months of his stay at Rome. He lived with a Manichean friend at first, and contracted a dangerous fever at his house. $\mathrm{He}$ then seems to have taken a house of his own, and announced classes of rhetoric for private students. In the golden age a private professor of rhetoric sometimes made a large fortune at Rome. Remmius Palæmon made 400,000 sesterces a year; whilst less gifted teachers starved in their attics. In the fourth century the teaching of rhetoric was chiefly confined to the public schools on the Capitol, where thirty masters formed a kind of university, to which youths were sent from all parts of the empire. Vespasian had begun the practice of the State payment of teachers-allowing rhetoricians I00,000 sesterces per year; Alexander Severus had founded a number of scholarships; and Constantine 
had granted teachers a number of civic privileges. The Capitol became a busy centre of higher education, and Valentinian had been obliged to place some restraint on the provincial and Roman youths in 370. They were to avoid evil company and disorderly banquets, and not to appear too often at the circus and theatre. At twenty they were to be sent back to their provinces.

Probably Augustine chose to teach in private from his preference for a few quiet youths. He does not seem to have remained in Rome even for a year. The Roman youths were more orderly than the Carthaginians, as he had been told, but they had a more serious failing. They used to plot together to desert their master and go to another school when the pay-day approached. Hence, when Augustine heard that the city of Milan had asked for a public professor of rhetoric, he applied for the post through his Manichean friends-though, he continues, with all the ungraciousness of a convert, ' it was in order to get away from them, intoxicated with vanity as they were, that I wanted to go.' The prefect Symmachus, who had been asked to find the teacher, made a trial of Augustine's ability, and accepted him. As Milan was now the second city in Italy, 


\section{I16 ST. AUGUSTINE AND HIS AGE}

we must assume that he had distinguished talent for his work, though he seems never to have had many private students. However, probably during the autumn vacation of 384 , he was conveyed to Milan by the state service, and found himself at length in the city of St. Ambrose.

The external life of Augustine during the next two years was as uneventful as his internal life was important and interesting. We know nothing of his teaching experience, save that he included amongst his pupils a number of friends from Africa. Romanianus, his friend and patron, sent his two sons, Licentius and Trigetius, to be educated by him. Nebridius, a Carthaginian youth, also followed him to Milan, as did also his 'little slave' Alypius. Alypius had studied law at Rome, and then accepted a post in the government service there, so as to cling to Augustine. He now came to Milan with the intention of practising at the bar. Romanianus himself was presently compelled to seek the court in the interest of his private affairs, and he joined the little African colony. Augustine also attached a number of cultured Milanese to himself. The position of a professor of rhetoric in a large town was, as I have explained, an honour- 
able one, and usually secured admission into the most coveted circles. The post was doubly important at Milan, as Augustine had occasionally to deliver the panegyric in presence of the emperor. On the feast of the coronation and a few other occasions the emperor held a reception of court and civil officials, whilst a rhetor read an elaborate discourse in praise of ' his eternity.' When one recollects the average duration of an emperor's life in the fourth century, eternitas vestra seems to have a grim sort of humour, yet it was one of the milder phrases used in these absurd speeches. Augustine felt the impropriety of the panegyrics keenly enough, but he mentions one or two occasions when he had to exercise his art before the boy emperor and his mother. We have neither of these panegyrics; but he hints ( $D e$ Ordine) that he had the disadvantage of a slight African accent, and his Latin was certainly greatly inferior to that of such rhetoricians as Symmachus.

But it is Augustine's inner growth that now claims our whole attention. We left him at Rome rather weary of the task of scaling the empyrean. Perplexed in thought and sore at heart, he was drawing back from the paths that 


\section{8 ST. AUGUSTINE AND HIS AGE}

seemed to offer an illusory guidance to the eternal hills. He was turning again to the glad cities that men had built on the broad plain of life. Honour, repute, a wealthy marriage, were ideas that began once more to grow large on the screen of his consciousness. Yet amidst the encrvation and confusion which resulted from his doubt and despondency, there were two truths that never ceased to cast an absorbing image on his mind; a conviction that the human mind was a thing apart in the universe, and that a divine mind embraced the whole in an all-seeing vision. How reconcile this incarnate perversity of a world with the being of God without the aid of the Manichean spirit of evil ? Manicheeism he had tried, and found too much disfigured with errors. It could not be the divine guide he sought; there were human philosophers who 'had said things which were more probable.' The Christian Scriptures he had read, and, fancying they were to be taken at the letter, had flung contemptuously aside. The teaching of the Platonic school was all but unknown to him when he decided that all human guidance was unavailing, and there must be a divine message obscured somewhere in ' the forest of sects.' Clearly, what he needed 
was, in the first place, a suggestion that the Old Testament must not be taken at the letter; and, in the second place, a philosophic introduction to the New Testament ideas of a spiritual God, the Trinity, and the Incarnation. In his work De Utilitate Credendi he indicates that he was in a frame of mind in which any masterful teacher could bear him along. His first such teacher was St. Ambrose, who led him half-way to the Christian Church.

It was probably well for him that he never came into intimate contact with the bishop of Milan. Augustine went to hear him frequently at the chief basilica. He sought rhetoric, not doctrine; and, although Ambrose was not an eloquent or an ornate speaker, there was an unaccustomed sincerity and a winning earnestness in his discourses. In spite of his prejudice Augustine followed his thoughts, and this quickly led to an important modification of his position. $\mathrm{He}$ learned that the Christian Scriptures were not to be interpreted literally. The stories of Genesis, at which he had laughed, appeared far less human in the light of Ambrose's figurative interpretation. All the Manichean objections to the Old Testament fell to the ground. The Christian gospel obtained 
a fresh interest in his esteem. He thought of consulting Ambrose about the remaining difficulties - the power of evil, the spiritual, the Incarnation, and the rest. I say it was well that he found this impossible. Ambrose was a most unsuitable councillor for such a situation, as his letters clearly show. In his thirty-fifth letter (Migne edition), for instance, he tells some one who has consulted him about similar questions concerning the soul to leave these 'trifles of the philosophers' alone and read-the book of Esdras! In his twenty-eighth letter, answering one who is astonished at the elevation of the ideas of Pythagoras the heathen, he says there is no cause for astonishment, 'since it is generally believed Pythagoras was of Jewish extraction.' In a work he wrote against the Platonists he contended that Plato learned his best ideas from Jeremiah. It is hardly likely that Ambrose would have found Augustine quite prepared for those ideas in $3^{8} 5$.

He had no opportunity for private conversation with the bishop about his difficulties. A bishop had the duties of a magistrate to discharge at that time, as well as his more properly episcopal functions. The bishop of Milan had 
other and more arduous duties. $\mathrm{He}$ was a politician and a statesman. In the preceding year he had successfully discharged a political mission to the usurper Maximus. In 385 he began his famous struggle with Justina, the emperor's mother. Justina was an Arian, and so were most of the councillors. There were few other Arians in Milan, but Justina demanded one of the basilicas of the city for the purpose of Arian worship, and there was a long and bitter struggle. The details of the conflict do not concern us, but it had probably already commenced when Augustine was anxious to consult Ambrose. He used to go frequently to the bishop's house, where no servant guarded the ever open door, and stand in silence for some time watching Ambrose reading or praying. $\mathrm{He}$ had not courage to ask an hour of his crowded life. Otherwise, he was on friendly terms with Ambrose. His mother, Monica, had joined him at Milan, and had won the bishop's admiration. Augustine tells a story of her going to the church, in the African fashion, with a basket of wine and cakes for the love-feasts of the martyrs. Ambrose had suppressed the custom on account of the drunkenness and disorderly scenes it gave rise to. 


\section{ST. AUGUSTINE AND HIS AGE}

Monica was, therefore, stopped at the door, and turned away, but she submitted at once when the matter was explained. Monica was one of the more sober Christians who regarded the ceremony in a purely religious light. One cup of wine, well watered, had to serve for the whole of the martyrs. She merely walked round, placing it on each tomb, and taking a reverential sip. Then she returned; leaving the wine and cakes, it seems, for the general festivity. Ambrose often congratulated Augustine on his mother.

Thus the service of St. Ambrose in the conversion of Augustine was restricted to a removal of his difficulties about the Old Testament. But the service was a very important one. As a result of it, Augustine now took up the Scriptures in a new spirit, and began at length to find a profound wisdom in the stories of Genesis. His attitude towards Christianity was greatly changed. As he so happily expresses it, he now felt that Christianity was not defeated, yet not a victor; not defeated by Manichean criticism, yet not victorious over his besetting difficulties about evil and spirituality. Augustine was never exacting in the matter of evidence. He had inherited a rare and enviable gift from his mother. As a 
pious Catholic she could not consult the astrologers, but she had a direct.communication with the higher powers in her dreams. "She used to say that she could distinguish by a kind of taste which she could not describe between Thy revelation and the images of her dreaming imagination.' So with Augustine. It was by a kind of subtle sense, that dispensed with the labour of seeking evidences and historical guarantees, that he tested alleged revelations. He was half persuaded that the Scripture answered this test. 'So I resolved,' he says, 'to remain a catechumen in the Catholic Church, commended to me by my parents, until some steady light should shine forth to direct my course.'

During the period of waiting for the dawn of this new light, Augustine's character was slowly developing in the direction in which his studies were leading. He had for some time discussed the question of marriage with his friends. No one who reads the Confessions can fail to notice how purely formal and calculating are the thoughts of Augustine at this period. Had he written at the time instead of fourteen years afterwards, no doubt he would have expressed some sense of, if not the moral, at least the emotional aspect 
of the proposal. His unfeeling phrases jar on the mind of those who 'would admire him. $\mathrm{He}$ has no sense whatever of obligation to the woman who has shared his life for fourteen years. Evidently, she belonged to a much lower condition of life than his own, and it would have been a miracle of self-sacrifice in the Roman world to have married her. But it is impossible to resist a feeling of resentment at Augustine's utter failure to see the injustice of such conventions. He who saw the whole world as one dark cemetery when his friend died, and who shows a sense of the honour of fidelity in his love, cannot have been without affection for her. Indeed, he admits, when he has tamely suffered her to be 'torn from his side,' that there is ' a raw and bloody wound in his heart where she had lain.' But he describes the steps which led to the separation in a quite heartless spirit. He wanted a wealthy wife, whose means would help to support the house. A discussion of the question with Alypius had an amusing result. Alypius was opposed to matrimony. $\mathrm{He}$ had tasted pleasure occasionally in the earlier years, and thought it was not worth the burdens and disadvantages which marriage would involve. Augustine assured him that his occasional pleasure 
was not to be compared with the joy of a constant attachment. The end of the discussion was that Alypius resolved to marry himself, so strong a 'curiosity' was excited in him by the warmth with which Augustine described the sacrifice.

Monica, naturally, encouraged Augustine's proposal. She saw how close he had approached to the Church, and thought his irregular attachment was the only hindrance to baptism. She had recourse- ' at my request,' candidly says Augustine - to her prophetic dream-faculty; 'but Thou wouldst not reveal anything to her in her dreams about my future marriage.' Monica was obliged to cast about like less gifted mothers, and she at length discovered a desirable party - a girl of ten years (Augustine was now thirty-two)-who seems to have had a respectable dowry. Augustine was willing to wait two years; in fact, it was by no means an uncommon occurrence to espouse a girl of ten when the dowry was attractive. Then came the discharge of the mother of Adeodatus. The Roman world regarded such an action as natural and commendable ; in the 'Eucharisticos' of Paulinus of Pella an entirely similar experience is described with equal callousness. The Christian world has been so overwhelmed with the heinousness of the 


\section{ST. AUGUSTINE AND HIS AGE}

attachment itself that this poor circumstance of human grief has passed almost unobserved. Yet it is hard to forgive Augustine the unfeeling brevity with which-save for one phrase-he dismisses the poor unknown from the story of his life. What pages would not Rousseau have written on such an episode! But Rousseau addressed his Confessions to humanity; Augustine to God. Just as we refuse to see so many of the tears that Jean Jacques is supposed to shed, so we may grant some to Augustine which he has forgotten in the splendour of the Divine Presence. Adeodatus remained with his father; his mother returned to Africa. It is evident that Monica was the chief agent in this, yet it is just as evident that Augustine had contemplated it for some time. ${ }^{1}$ To complete this sorry page of Augustine's life, we have to add that his companion had not been gone long before he 'procured another' to minister to his uncontrollable passion during the two years of waiting.

1 The hagiographer generally says that the poor woman was converted and entered a nunnery, or at all events took a vow of chastity, in Africa. Augustine says: "She returned to Africa, vowing to Thee she would know no man again.' It seems to me the usual interpretation is strained. 'Vovens tibi,' may very well mean that 'she vowed and swore [every African, including Augustine, swore habitually] she would have nothing more to do with men'; either in anger, or in her great love for Augustine. We know absolutely nothing of her beyond what I have stated. 
It was about this time that Augustine discussed with his friends the idea of forming a philosophic community. There was nothing particularly ascetic about the proposal, but quite a small colony of Afro-Romans had met at Milan, as I have explained. Alypius was seeking legal practice there. Nebridius was teaching in the school of a friend. Romanianus was furthering his interests at court. Altogether it was thought that ten would be willing to club their resources and maintain a common household. Romanianus was a very wealthy man, and even Alypius and Nebridius seem to have been in better circumstances than Augustine. But the rhetorician was the centre, the most commanding personality of the group. He had led them all (except the shrewd Nebridius) into Manicheeism, and he was to lead them all into Christianity. They proposed to have a common purse, and appoint two of their number each year to take charge of the business of the household; leaving the majority free to pursue their studies, and discourse uninterruptedly of learning and philosophy. The proposal was wrecked on a familiar rock. As soon as the question of women was raised, the plan fell to pieces. Clearly, Augustine and his friends were 
poorly acquainted with the complexion and the success of Epicurus's famous community at Athens.

It seems likely, however, that the Epicurean community had inspired the idea. Shortly after telling the failure of their project, Augustine declares that he was greatly inclined towards Epicureanism. Unfortunately, he has the very common misapprehension of Epicurean teaching. It is not a flattering picture that Augustine offers us of himself, standing impatiently on the brink of the flood of bodily pleasure, and only withheld from a plunge into its lowest depths by the dread of death and what may lie beyond it. Whether or no this is an overdrawn picture of his own position, it certainly does injustice to Epicurus. Throughout his works Augustine insists that Epicurus found man's true aim in 'bodily pleasure,' and opposes this to the 'virtue' which was the summum bonum of the Stoics. In a carefully prepared sermon, which he delivered at Carthage (sermo I 50), he even speaks of ' the uncleanness of the Epicureans,' and will have it that they filled their lives with sensual pleasure because they did not believe in a future state. That is an error which will probably live as long as Stoicism or the 
Church. Epicurus said that he saw no sound reason for admitting a future state, that the soul was but a finer texture of matter, and that this absence of anxiety about a life beyond would contribute to the tranquillity of the present life. Not bodily pleasure, but a full and rounded happiness, was his ideal. He led 'an unusually moderate and contented life,' ' a model life,' says Zeller, neither in isolation nor in indulgence of sense, but in a sober and affectionate comradeship. 'We cannot live pleasantly [happily],' he used to say, 'without living wisely and nobly and righteously.' Seeing no convincing proof of the immortality of the soul, he advised men-not to eat and drink and make merry-but to ponder well all the gifts that nature bestows or suggests, and follow those that promise a happy and tranquil career. That was the sum and substance of the 'uncleanness of the Epicureans.'

There is this truth in Augustine's ill-informed statement, that he still wavered between the facile pleasures of the plains of life and the frail charm of the arduous hills beyond. Time after time his idealist ardour faded, and the thoughts of wedded joy, and the honour of men, and the soft luxury of wealth, invaded his soul. We have just seen 


\section{I30 ST. AUGUSTINE AND HIS AGE}

how weak a purpose he opposed to the passion of love; later we shall hear him complain of a leaning towards good living (Confessions, x. 3I). Yet we have seen good reason to think he was far from being what we should call a sensual man. We must understand the sharp antithesis of ideals in his day. Now we are all Epicureans, only some of us trust to extend our Epicureanism into a coming life as well as this. In the early ages of the Christian era a serious man held that Epicureanism, even justly and soberly conceived, was incompatible with a full acceptance of the teaching of Christ. And Augustine's Ciceronian vision was rapidly melting into a Pauline prospect. The hills beyond were the eternal hills of the Scriptures, he was fast becoming convinced. That is why his purpose wavered in proportion as he felt that he approached the path he had sought so long. A profound moral struggle was preparing. He grasped at every excuse for deferring the last investigation. 'When shall we seek the truth? Ambrose has not time : he has not time to read. Where shall we get the books? . . . In the forenoon the pupils occupy us: what do we do afterwards? Why not this? But when shall we salute the friends whose patronage we need? When shall we prepare our lessons ? 
When shall we recreate ourselves, relaxing the mind from care?' The eternal story. But again the clouds darken the cities on the plain, and the hilltops shine forth. One day he sees a drunken beggar in the street, who has purchased the happiness of an emperor for a few small coins. It casts a shade on his ambition. This man is happier than he, yet has bought his joy so cheaply. He turns to his books, and the problem of evil absorbs his fruitless hours, and the idea of a spiritual God, which he has heard in the sermons of Ambrose and the conversation of a Platonist friend, Manlius Theodorus, the future consul, mocks the low flight of his imagination. 'These things I turned again and again in my wretched breast, weighed down with crushing anxiety from my fear of death and my hopeless quest of truth.' How far from the tranquillity of Epicurus!

In this condition we find him at the beginning of 386 , when the last step in his progress towards the Church was taken. A friend-with his usual gracelessness he says, 'a certain man who was inflated with a stupendous conceit'-sent him 'certain books of the Platonists, recently translated into Latin from the Greek.' The translator was Victorinus, a distinguished Roman rhetorician, who 


\section{ST. AUGUSTINE AND HIS AGE}

$\gg$ afterwards became a Christian. Augustine nowhere indicates the names of the works which 'lit up an incredible flame' within him, but recent research ${ }^{1}$ has identified them with some confidence. It was almost certainly the works of Alexandrian Neo-Platonists, not of Platonists, that he read at this time. Augustine's history of philosophy is very defective. Nourisson, writing under the eye of a bench of bishops, cannot refrain from calling Augustine's erudition 'undigested,' 'superficial,' 'mediocre and very imperfect'; 'ce n'est point un savant,' he says at length. Even Ellies Dupin says ' he had more ability than erudition.' At all events, Augustine is always confounding Platonists, Neo-Platonists, and Academics-three widely different schools-and fancies Aristotle was a faithful follower of Plato. For many years he accepted Ambrose's theory that 'Jeremiah' had given Plato his 'golden thoughts.' Confined as he was to Latin literature, we cannot expect to find in him a close acquaintance with Greek thinkers. It is generally thought he read a translation of the Timeus; M. Saisset thinks he was acquainted with the Phedo, Phedrus, Republic, and Gorgias;

1 See the chref points in Nourisson's Philosophie de Saint Augustin and Grandgeorge's Saint Augustin. 
and M. Nourisson would add the Banquet. Certainly he builds throughout life on some of Plato's most distinctive notions. The theory of ideas, and the antithesis of the world of sense and the world of mind, are basic thoughts in his system. From Aristotle he has borrowed those ideas of time and eternity which are so familiar to readers of the Confessions and the City of God, as well as his definition of the soul and his idea of matter and form.

But it is very difficult to prove that he read any works of either Plato or Aristotle, except perhaps the Timeus, which was much read in his day, and Aristotle's Categories and Dialectics. The Alexandrian philosophers affected to select the sounder and more striking thoughts from Pythagoras, Plato, Aristotle, and the rest, and Augustine would find all he has learned in them. There are fe, philosophic ideas in his works which cannot be found in Porphyry or Plotinus. Nourisson 'cannot find a single original idea in his philosophy' at the close of his careful analysis ${ }^{1}$ and the tabulated comparison of Grandgeorge seems to trace every important thought to the Alexandrians. In the City of God, indeed, Augustine 1 op. cit. ii. 276. 


\section{ST. AUGUSTINE AND HIS AGE}

calls Plotinus, Jamblichus, and Porphyry 'the Platonists.' It seems quite clear that it was some Neo-Platonic works which fell into his hands in 386 ; and it is probable that the chief of these was a translation of the Enneads of Plotinus. There, at all events, we find the ideas which immediately bridged over the last mental gulf that separated Augustine from Christianity.

Augustine's most stubborn difficulty throughout had been the power of evil. The chief fascination of the Manichean system had been that it afforded a plausible explanation of this central fact of life, this hideous corruption, spreading like a cancerous growth over the fair frame of the world, that has absorbed every sincere thinker from Buddha and Zoroaster to Goethe and Schopenhauer. The one sacred and abiding principle in Augustine's mind was the existence of God, and hitherto he had utterly failed to reconcile it with the plain features of life. Plotinus supplied him with a magical formula that dissipated his anxiety like a disease of the overburdened mind. For the rest of his days Augustine found the presence of evil to be one of the most natural and harmonious qualities of creation. The suggestion of Plotinus had the ideal simplicity which often marks great thoughts 
-or great phrases. Evil is not an entity at all. It is a failure of things to reach perfection. Why do you seek an efficient cause of a non-entity? Or on what ground do you demand that God should create a perfect world-if that were possible-or none at all? Nay, would the world be perfect without the wholesome stimulus of pain? And so the great magician charmed away the sorrow and ugliness of life with his phrases, and inspired the optimism which from that day resented as blasphemy all talk of reconciliation with our Maker for his misdeeds. But Augustine had already gathered from the Scriptures and from Ambrose's sermons that his idea of God was wholly wrong. The Manichean system was frankly materialistic. There were finer and coarser textures of matter, but the whole of existence was like what our senses perceive. Dimly and with much perplexity Augustine had realised that the Christians placed their God in a higher world. He was incorporeal, like a mathematical quantity, yet real and substantial. His imagination had fallen back helplessly to earth whenever it had tried to picture this spirit-God. Plotinus once more, with a single flash of thought, illumined a path for him which he had never seen before. 


\section{ST. AUGUSTINE AND HIS AGE}

Is truth corporeal? Is it not real? He was led into the entrancing idea-world of Plato, and the Pythagorean science of numbers. At a bound he was away from the solid earth of Epicurus and Mani, and found himself in the land of the eternal and incorruptible spirit. Truth and beauty and goodness, the most thrilling realities of life, lived in an imperishable world; they had an unchanging reality in themselves, sublimely independent of the faint and broken reflection of them that ennobles this transitory universe. Then, all is not corporeal. And if truth is incorporeal, must not its infinite source be incorporeal, eternal, immutable, and all-pervading, like itself ? And could the mind perceive it if it also were not spiritual $\Rightarrow$

So, one by one, the bonds of Manichean teaching fell from him, and he found himself thinking the thoughts of the Gospels. Whether it be that 'Plato wrote a human preface to the Gospels,' as De Maistre said, or that the evangelists wrote a human appendix to Plato, as others think, it is hardly our duty to inquire here. But we may be permitted to express less astonishment than Augustine felt when he read, point by point, in the Alexandrian philosophy, what he already knew 
to exist in Alexandrian theology. Plato's doctrine of the Logos (borrowed from Moses, according to St. Justin) had, as it was presented by Plotinus, a singular resemblance to that of St. John. Plato's Trinity, as described by Plotinus, was sufficiently rational to recommend itself, and sufficiently Alexandrian to recommend the Nicene Creed. Under the seductive guidance of a philosopher, who appealed to his reason, he found himself accepting doctrines for which a blind submission had been demanded. The Platonic and Neo-Platonic ideas were, it must be remembered, brought before him by Christians, in a Christian atmosphere. $\mathrm{He}$ saw them only as stepping-stones across the river that divided his mind from the Church. He now found himself, intellectually, on the very threshold of Christian theology. He had gathered the ideas which he afterwards develops with so much ingenuity in his philosophic works. ${ }^{1} \mathrm{He}$ remains a Platonist throughout life. His early works are full of generous admiration for those who saved him from what he regarded as the bondage of material-

1 In order to complete the present matter let me add that C. Frick (in his Die 2uellen Augustins) assigns as the Latin sources of his learning, Varro, Cicero, Seneca, Aulus Gellius, and Apuleius, and for history chiefly Josephus and Pompeius Trogus. 


\section{I38 ST. AUGUSTINE AND HIS AGE}

ism. But mark the price of progress in sanctity. When he comes to write his Confessions (about 400), he speaks only of their 'presumption' and of the 'stupendous conceit' of the friend who gave him the books. Fifteen years later, when he is writing the eighth book of the City of God, he says Plato is not only not a god or demi-god, but is not to be compared with an angel or prophet, an apostle or martyr, or, in fine, with any Christian whatever. Eleven years afterwards he writes in his Retractations: "The praise which I bestowed on Plato and the Platonists or Academics [the usual confusion], and which it was not proper to bestow on those impious men, rightly displeases me; especially as we have to defend Christian teaching against their great errors.'

The last step in his intellectual conversion was quickly taken. From Plato, or Plotinus, he turned to Paul, whom he now read without difficulty. He himself somewhat curiously describes the additional truths he found in St. Paul after the reading of Plato. $\mathrm{He}$ says that after reading the Platonists he only conceived Christ as ' a man of excellent wisdom,' God as a Being of infinite and inaccessible splendour; 'and, return- 
ing to my customary ways in this beating back of my infirmity, I bore with me only a loving memory, only a desire of the sweet-smelling fruits I could not yet eat.' Paul taught him the humanity of Jesus : that God ' had built Himself a lowly house of our clay, by which $\mathrm{He}$ should subdue and draw us to Himself, healing the swollen pride and fostering the love of His subjects, lest they should go too far in their confidence, but should rather turn to lowliness, seeing the lowliness of God at their feet, in the taking of our garment of flesh, and should sink exhausted into Him ; and He should rise and uplift us.' And again : 'It is one thing to behold the fatherland of peace from some wooded hill, and discover not the path to it . . . and another to hold the way that leads thither, fortified by the care of the Heavenly King.' Another interesting thought occurs in his De Vera Religione, which illustrates his passage from Plato to Paul. He describes what he conceives to be the teaching of Platoit is really that of Plotinus with the Christian features emphasised. He then shows how unable Plato was to communicate this sublime conception of God to the masses, how powerless the wisest of mortals would be to convert the world to it. He 


\section{ST. AUGUSTINE AND HIS AGE}

thinks Plato himself would admit that only a being of divine strength and wisdom could achieve that conversion; in other words, Plato himself would have accepted the Incarnation of Christ without demur. His long quest of truth was over. From a somewhat Christianised Platonism he had passed without difficulty to a Platonic Christianity. Mr. Marcus Dods has said that Augustine's acceptance of Christianity 'was no more radical than his scepticism.' Mr. Dods might appeal to one of Augustine's heretical opponents, Petilianus, who said he had 'the damnable talent of a Carneades.' However, though it is true Augustine never was a sceptic, it is monstrous to say that he was not wholly convinced of the truth of his new religion. 


\title{
CHAPTER VII
}

\author{
CONVERSION
}

When Augustine spoke of his Platonist education as a vision of the promised land from the summit of a wooded hill, he was speaking as a Christian. In reality, Neo-Platonism was much more than a philosophy. It was a religion, and a religion of ascetic character on its ethical side. Augustine somehow ignores this side of the Alexandrian system, and finds in it nothing to correspond to the severe practical discipline of the Epistles. From that point of view he had some reason to say that the Platonist merely described heaven, while St. Paul indicated the path to it. In our own day the process of conversion would be complete with the mental progress we have already followed. The convert would go on his secular way, heeding nothing of paths to heaven beyond a certain sobriety of life. 
But when Augustine turned to St. Paul, he discovered that a new gulf lay between him and the Christian ideal. He learned that even marriage was a concession to the weakly; that 'they that are Christ's have crucified the flesh with the affections and lusts.' Certainly, this crucifixion was not a matter of obligation. He looked about him in the Church, and saw 'that one went this way and another that.' But Paul's doctrine was clear. The way of the strong and the generous, the only secure way to heaven, was the way of detachment from the things of earth. Then began a fiercer struggle than he had yet known, the struggle of the ideal and the commonplace in its tensest form. It was not merely a question of discharging his mistress, as is sometimes represented. Rightly or wrongly, he understood by an acceptance of Christian teaching a renunciation of all love, all wealth, all ambition of this world. These were roses in the path of life, said Christ and St. Paul, only to captivate the weak and deepen the strength of the strong. 'I no longer yearned to be more certain about Thee, but to be more steadfast in Thee.'

They who picture the last struggle in the conversion of St. Augustine, the best known page in 
his life, as a struggle with sin, miss its real significance. He hardly mentions the irregular attachment which held him; he does not say a word of the dismissal of his second mistress, and we can only place it by conjecture. It is matrimony he speaks of continually. It is the sacrifice of all love of woman for the rest of life that offers so piercing a prospect to him. Christ or Epicurus ; the roses of this world or those of the next. A mind like his wanted no 'concession,' in case he was 'afraid to sleep by himself,' or as an alternative to damnation. It seemed to him only a few years since Christ had trod the roads of Roman Palestine, and made self-denial the test of discipleship. The thought of wealth and fame he was ready to abandon; 'but I was still firmly held by woman.' In his perplexity he consulted an aged priest of Milan, Simplicianus, the spiritual father of St. Ambrose. By a fortunate chance the priest had a word for him which was better than much counsel. Augustine told him of the Platonist works he had been reading, and this brought the conversation to Victorinus, the translator. Victorinus was a distinguished rhetorician, to whom a statue had been erected in the Roman forum. Under the direction of Simplicianus he had joined 


\section{ST. AUGUSTINE AND HIS AGE}

the Christian Church, to which his Neo-Platonism had long disposed him. The event had caused great excitement in Rome. His school had been attended by a number of senators of high rank, and, besides the statue, the title of clarissimus had been voted him. But Rome regarded his conversion with little favour, and he had to retire from the schools. The parallel was close enough to make a deep impression on Augustine. The internal struggle deepened. 'I was pressed down with the burden of the world, as happens at times in sleep; and the thoughts which I directed to Thee were like unto the efforts of those who would awake, yet sink back into the deep sleep they have broken.'

But one day he and Alypius had a visit from a fellow-countryman in the imperial service. In front of Augustine, as they sat to converse, was a book lying on a gaming table. Pontitianus opened it, and did not disguise his astonishment on finding that it was a copy of the Scriptures. Augustine told him he was 'earnestly bent on the study of that book.' Thus the conversation took a religious turn, and Pontitianus, being a devout Christian of long standing, told them the story of Antony and the monks of the African desert. 
The story entered like fire into the soul of Augustine. Pontitianus continued to talk of vocations and monasteries. At Trèves, a few years previously, two of- his fellow-officers had been suddenly converted to the monastic life by reading the story of Antony. The two ladies to whom they were espoused followed their example. Augustine realised with a profound astonishment that what he had trembled before as an Herculean task was being accomplished by unlettered men and frail women day after day within a few miles of him. When Pontitianus left them, Augustine took his soul in his hands, and faced the dilemma of his life. 'All my arguments were undone; there remained but a speechless terror, for my soul dreaded as death itself to be taken from its customary stream which was bearing it to death.' Presently he cried to Alypius, who looked at him in silent astonishment: "What are we doing? What is this? What hast thou heard? The unlearned rise up and take hold of the kingdom of heaven ; whilst we, with all our learning, without heart, are slaves to flesh and blood.' $\mathrm{He}$ rushed into the garden, Alypius following, too agitated to think or argue. The supreme moment had come. It would be an injustice to the reader 


\section{I46 ST. AUGUSTINE AND HIS AGE}

to describe the issue in any other words than those of Augustine :-

' Thus was I sick at heart and in torment, accusing myself more bitterly than ever, tossing and turning in the frail bond that still held me, until it should break asunder; frail it was, yet it held me still. And Thy strict mercy was working within me, Lord, lashing me with fear and shame that I might desist no more, nor fail to break the slender bond that yet remained; lest it should grow strong again, and hold me more firmly than ever. For I said in my heart : "Let it be now, let it be now." And I almost went to work as I said it. Almost had I done it, yet did it not; nor yet did I fall back into my earlier state, but stood nigh to it and breathed. I tried again, and with a little more I was there, with a little more I reached and held it; yet I was not there, nor reached, nor held it, hesitating to die to death and live to life. The force of evil custom was stronger in me than the new resolution $;^{1}$ and the nearer the moment approached in which I was to become better, the greater the dread it struck into

1 With some reluctance I must point out that here, in the midst of this moving passage, occurs one of Augustine's wretched wordplays. 


\section{CONVERSION}

me. It drove me not from my purpose, nor turned me aside; but it held me in suspense. Trifles of trifles and vanities of vanities, my former joys, held me back, and plucked my fleshly garment, and murmured: "Dost thou cast us off? and from this moment wilt thou leave us for ever? and from this moment will this or that be forbidden thee for all eternity?" And what things were those they held out to me, my God, which I have called "this or that"? May Thy mercy keep them from the soul of Thy servant. What defilement, what dishonour! And now I did but half hear their voices; they no longer stood boldly in my path and said me nay, but muttered behind me, as it were, and furtively plucked my garments, as I walked away, that I might turn and look upon them. Yet they made me slow to shake them off, and leap forward whither I was called, when rooted habit said to me: "Dost thou think thou canst live without them?"

'But now it said this faintly. For from the side toward which I had set my face, and to which I was hastening, there stood revealed the chaste dignity of continence, serene, joyful without dissoluteness, gravely beckoning me to come and 


\section{ST. AUGUSTINE AND HIS AGE}

hesitate not, and stretching forth to receive and embrace me pious hands that were full of good examples. So many boys and girls, so many youths, so many of every age, so many modest widows and aged virgins; and in all these continence was not barren, but the fruitful mother of joyous children of Thee, $O$ Lord. And she laughed at me with a laugh of welcome, as though she would say, "Canst thou not do what these have done? Or did they, indeed, do it of themselves and not in the Lord? The Lord their God gave them to me. Why dost thou neither stand still nor advance? Cast thyself upon $\mathrm{Him}$; fear not lest $\mathrm{He}$ withdraw His hand and thou fall ; cast thyself fearlessly, $\mathrm{He}$ will receive and heal thee." And I blushed exceedingly: for I still heard the murmur of those trifles, and lingered on the way. And again she seemed to say: "Listen no more on earth to those unclean members of thine, that they may die ; they tell thee of delights, but not according to the law of the Lord." This was the struggle that raged within me against myself. Alypius, standing by my side, waited in silence the issue of my unwonted emotion.

'But when profound reflection had drawn my whole misery from its secret depths, and heaped 
it up in the sight of my heart, there came a great storm with mighty shower of tears. And, that 1 might pour it all forth with fitting words, I rose to depart from Alypius. It seemed to me that solitude was more fitting for my tears. And I went further apart, so that even his presence would no longer be a burden to me. Thus was I minded, and he knew it ; for I know not what I had said, revealing the sound of my voice already heavy with grief, and had then arisen. He, therefore, remained in great astonishment where we were sitting. I flung myself beneath a certain fig-tree, and gave the rein to my tears; and the floods burst forth from my eyes, an acceptable sacrifice to Thee. And many things I said to Thee in this sense, though not in these words : "And Thou, Lord, how long wilt Thou delay? Wilt Thou be angry for ever, Lord? Be not mindful of my earlier iniquity." For I felt I was hampered by it. I poured out words of misery : "How long? How long? To-morrow, and to-morrow? Why not now ? Why not end my baseness this very hour?"

'And, speaking thus, I wept with a most bitter contrition in my heart. And suddenly I heard from a neighbouring house the voice, as it were, of a boy or girl singing many times: "Take up 
and read, take up and read." I was roused immediately, and began to think intently whether children were wont to sing this in any game of theirs; but I could not recollect ever to have heard it. And, checking the flood of my tears, I arose, thinking no other than that it was a Divine command to me to open the sacred volume and read the first chapter I lighted on. For I had heard it said of Antony that he took to himself the words of a lesson from the Gospel which he chanced to hear, as though the words were read to him : "Go, and sell all thou hast, and give to the poor, and thou shalt have treasure in heaven, and come and follow Me"; and that he was forthwith converted to Thee by this oracle. Thus admonished, I returned to the spot where Alypius sat; for I had placed the volume of the Apostle there when I had left. I grasped and opened it, and read in silence the chapter which first met my eyes: "Not in rioting and drunkenness, not in chambering and wantonness, not in strife and envying. But put ye on the Lord Jesus Christ, and make not provision for the flesh, to fulfil the lusts thereof." I neither wished nor needed to read more. For with the close of this sentence the darkness of my 
doubt melted away, as though a strong light had shone upon my heart. Then, inserting my finger or some other mark, I closed the book, and with a tranquil mind handed it to Alypius. Then he betrayed what was passing within him, which I knew not; he asked to see what I had read. I showed it to him; and he read on beyond the place I showed him, and I knew not what followed. But what followed was: "Him that is weak in the faith, receive ye." This he took to himself, and showed to me. With this admonition he was resolved; and without trouble or hesitation he joined with me in the good purpose, so befitting his ways, which were already far in advance of mine. We return to my mother in the house. We tell her, and she rejoices. We relate how it came about; she exults in triumph, and blesses Thee who art powerful to do more than we seek or know, for she saw Thou hadst granted her in my regard so much more than she had asked in her sad and tearful prayers. For Thou hast converted me to Thee so that I no longer seek wife nor any hope of this world, holding fast to the rule of faith in which Thou hadst revealed me to her so many years before. And Thou hast changed her grief into a joy far deeper 


\section{ST. AUGUSTINE AND HIS AGE}

than she had desired, far dearer and chaster than that she had sought from the children of my flesh.'

This was in the summer of 386 , shortly after the final triumph of St. Ambrose over the empress and the Arian party. Justina had an inflexible and incorruptible prelate, as well as a statesman, to deal with in the bishop of Milan, and she had suffered unmitigated defeat. Augustine was only a spectator of the great struggle that had so long absorbed the attention of Milan. The Duc de Broglie makes him spend the night with the people and Ambrose in the church; but Augustine expressly says that Monica alone shared that famous vigil. Gibbon is hardly fair to Ambrose in the matter. The empress had no shadow of a title to either of the churches which she claimed for her Arian priests ; it would have been a gross betrayal of his trust for Ambrose to surrender either. The renewal of the struggle in the Holy Week of 386 is not so clear. We know that on other occasions Ambrose refused to obey an order to appear at court in a way that boded ill for the civil power. Whatever may be the right of the matter, it is well known how his congregation gathered about the bishop, when the court 
threatened to banish him, and watched him day and night in his house and the church. It was then that Ambrose introduced into the church of Milan the custom of singing hymns which prevailed in the East. Ambrose himself composed many. In June, moreover, Ambrose made a most fortunate find of martyrs' relics, which put a final term to 'the woman's madness.' Not only were there many cases of recovery from that opportune disease, diabolical possession, but even a blind man was restored to sight. ${ }^{1}$

It must have been a few weeks after the discovery of the relics of Gervasius and Protasius that Augustine's conversion took place. It caused little excitement in the city, because he kept it a profound secret from all but a few personal friends for the few weeks that still remained before the summer holidays. Then, though he talks much

1 Gibbon 'would recommend this miracle to our divines if it did not prove also the worship of relics.' The divines of our day would hardly complain of that circumstance, but they seem to entertain some doubt as to the value of Augustine's testimony in such matters, of which we shall see a few illustrations later. Even here, whereas Augustine says the 'bodies' were incorrupt, Ambrose only speaks of 'bones' and some blood. The life of Ambrose in the Migne edition says Augustine 'was present' at the discovery or the miracles. Augustine expressly says, in the Confessions, that he was not. Moreover, we shall see presently that he most probably did not admit these miracles until years afterwards. 


\section{ST. AUGUSTINE AND HIS AGE}

of his joy at ceasing ' to sell lies and folly,' he sent in a prudent notice that the state of his health (his lungs were giving way) as well as his conversion compelled him to resign. Augustine himself hints that the manner of his secession will not look very heroic to the faithful at large. There is a curious mixture of desire to avoid ostentation and popularity and sensitiveness to hostile criticism in the many reasons he gives for keeping his conversion a secret.

However, at the close of the scholastic year, Augustine retired to the villa of his friend Verecundus, some miles out of Milan. A local tradition claims Cassago as the 'Cassiciacum' where Augustine spent the following six months. M. Poujoulat, however, seems to have made out an unanswerable case for Casciago, a quiet little town at the foot of the mountains. To the northwest it had the superb horizon of Monte Rosa and the Pennine Alps, whilst the hills encircled it also on the north and east, giving broken glimpses of Maggiore and a few smaller lakes to the north-east. To the south-east lay the broad panorama of the plain, dotted with towns and villages, and relieved by an occasional hill. Here Augustine spent the autumn and winter. 
His mother and son accompanied him, and they were joined presently by his brother Navigius. Alypius followed like a shadow, save that he far outran Augustine in ascetic feeling, 'going so far as to tread barefoot the frozen soil of Italy.' Two of Augustine's cousins, Rusticus and Lastidianus, a compatriot from Thagaste named Evodius, who had already been converted and abandoned the imperial service, and the two pupils, Licentius and Trigetius, completed the group.

In the Confessions Augustine says very little about their life at Cassiciacum, but we have many pictures of it in the short treatises he composed there. It must have been one of the happiest periods of his life. Apart from the lessons he continued to give Licentius and Trigetius and the administration of his friend's estate, his whole time was given to study and intellectual and religious conversation. The morning was usually devoted to teaching, and the rest of the day, after the midday meal and sleep, to discussion. Monica presided over the household matters; but she, and even the young Adeodatus, often took part in the discussions. On feast-days, such as Augustine's birthday, the whole day was given up to this 


\section{ST. AUGUSTINE AND HIS AGE}

intellectual dissipation. If the weather were fine, they went to a neighbouring meadow, and held their Academy under the shade of a tree. In rough weather they went to the baths for the purpose. The Roman bath, of course, contained many rooms for games and conversation besidesithe tepidaria, caldaria, and frigidaria, which were used for the bath proper. Augustine and his friends frequently held discussions there which demanded a quiet retreat. In these discussions Augustine was the chief speaker, but he shows some eagerness to draw out every member of the group. Nebridius remained at Milan, teaching for Verecundus. Licentius, the clever but dreamy son of Romanianus, seems to have been bored by the conversations at first. He was, in fact, the last of the group to embrace Christianity. ${ }^{1}$ The young Adeodatus put in a boyish word occasionally, and Augustine finds a profound wisdom in the contributions of Monica. The instances he gives are not impressive. Thus, they were one day discussing the followers of Carneades, and Monica asked who these Academics were. When

1 Lanciani (Pagan and Christian Rome) says his body was discovered in St. Lorenzo at Rome in 1862, and there was evidence that he had both attained his ambition of senatorial rank and had died a Christian. Verecundus also died a Christian. 
the explanation was given, she laughed and said: 'Those men have the falling sickness.'

The subjects of their discussions were of the philosophico-religious character which we can well conceive to reflect Augustine's temper at that time. In Scripture he was studying the Psalms. Ambrose had recommended Isaiah, but Augustine found the Psalms more suited to his disposition. It was, however, a passion for reasoning that chiefly characterised the stay at Cassiciacum. In a letter which he wrote at the time to Nebridius Augustine speaks of reasoning as ' my darling.' The phrase seems to have escaped him when he was writing his Retractations in 426 ; there were so many things to amend in the writings of those early years. Fortunately, the chief discussions they held were committed to writing, so that we have a large acquaintance with Augustine's early ideas. Those who are astonished at the number of his works should bear in mind the notarius, or shorthand writer, of the later Roman world. He was as ubiquitous with his style and tablets as the modern reporter. Within a couple of months of the arrival at Cassiciacum we find that Augustine has at his elbow the shorthand writer who is to shadow him throughout life. He sits amongst 


\section{I58 ST. AUGUSTINE AND HIS AGE}

them in the meadow or at the baths, and commits to his waxed tablets every word that is spoken ; his style is even busy whilst they chat in returning to the house, and he records how Monica impatiently drags them in to the expectant dinner. The notes are then copied into 'long-hand,' revised by Augustine, and we have one of his thousand works. ${ }^{1}$

The first work which was composed in this way consisted of the three books of dialogues, Contra Academicos. The master had given his pupils the Hortensius to read, and had then introduced his notary, and started a discussion on the pursuit of truth. It is a sad proof of the slightness of Augustine's knowledge of the history of philosophy that he suggests (an opinion which he frequently repeated in after life) that the Academics were not really sceptics at all, but held the ideas of Plato, which they concealed by a kind of philosophic 'discipline of the secret.' However, he proposes for discussion the theory commonly attributed to them - that man can never reach the truth, though he may find happiness in the pursuit of it. His two young

1 Possidius, his disciple, numbers 1030 of his works, including letters and sermons. 
pupils debated the question for three days. When Augustine saw that the defender of Arcesilaus was prevailing, he restored the balance himself with a crushing sophism on the nature of verisimilitude. In the third book he makes his own attack on the post-Socratic Agnostics, and finds a ground of certainty in his Platonic conception of the soul and of rational truth. As there were few followers of either the Middle or the New Academy at that time, and Augustine himself had never been seriously inclined to a radical scepticism, the work has not the force of most of his polemical productions. The only important retractation he found it necessary to make in his old age was, as has been said, a regret that he had given undue praise to 'those impious men, Plato and the Platonists or Academics.'

The composition of this work was interrupted by the production of the dialogues De Beata Vita. On November I $3^{\text {th, }}$ in the midst of the onslaught on the Academics, occurred Augustine's thirtythird birthday. A birthday was as important an institution in the Roman world as it is in our own, greetings and presents and family banquets marking the occasion. After a modest feast of the body Augustine led his philosophic party to the 
baths, promising them ' $a$ feast of the soul.' The feast consisted of a three days' discussion on 'The Happy Life,' which was afterwards embodied in the work of that title. More interesting is the work which followed the books 'Against the Academics.' It was a habit of Augustine's in the long winter nights to lie awake thinking for the first half of the night. One night as he lay philosophising in this way, his attention was caught by the irregular sound of the stream that made its way to the baths some distance from the house. He began to speculate on the cause of the irregularity, and soon found himself pondering on regularity and irregularity at large. As he reflected, a noise made by Licentius (the two pupils slept in the same room as their master) in driving away a mouse, told that he also was awake, and he was invited to discuss the phenomenon. Trigetius joined in the discussion, which seems to have been maintained throughout the night in the dark. The following morning they went to the baths to continue it, and the subject received an enlargement from their chancing to witness a cock-fight in the street. From Augustine's vivid description of the encounter, it is sadly evident that the philosophic group formed an admiring 
ring round the combatants. A few years previously Augustine would have seen in it-as in all nature ' red in tooth and claw' - a very tangible proof of the Manichean theory of an evil spirit. Now he almost finds in it a proof of the existence of an all-wise and all-loving Creator. The two incidents suggest the long debate 'On Order,' which forms his third extant work. It is chiefly. grounded on the Neo-Platonic optimism and idea of Providence, and contains an appreciation of the Pythagorean idea of numbers which Augustine was careful to modify later on.

A little later Augustine himself wrote the Soliloquies, a Platonic dialogue between 'A.' and 'R.'-presumably 'Augustine' and 'Reason.' It is a profoundly earnest and, in places, eloquent paper on truth and immortality. Truth is now, for Augustine, merely a knowledge of God and the soul. Later, as his mind narrows, we shall find him make truth synonymous with a knowledge of what the Scriptures tell concerning God and the soul. In 387 he was still a rationalist. It is mainly Platonic thoughts about the pursuit of truth and Platonic proofs of the immortality of the soul that inspire him. But the work is a subtle, feeling, and graceful develop- 
ment of the ideas he has received; and there are eloquent passages in his exhortation to abandon the world of sense for this pursuit of truth.

These are the earliest expressions of Augustine's views which we have. With the exception of his De Vera Religione, none of his smaller works contain finer writing than the sections of these books which he has himself written at leisure. Yet Augustine's Latin is never of a very high order. In the fourth century the language had fallen much below the level it had reached in the golden age of Latin literature. We have in his day, it is true, what may without exaggeration be described as a literary revival. Symmachus and Jerome, Macrobius and Ammianus, Prudentius and Paulinus, Claudianus, Rutilius, and Ausonius form a notable group. But, as has been said, the fourth century was formalist and imitative in its conception of literary art; and so affectation, verbal jugglery, and other unseemly features had crept into the language. Moreover, in the long interval of comparative sterility, the 'plebeian language' had invaded the domain of culture. Both these defects are conspicuous in Augustine's writings. Villemain contrasts his Latin very unfavourably with 'the fine Roman 
diction' of Jerome. In philosophic thinking he is leagues ahead of his contemporaries, in so far as we know their achievements, but this very proficiency in philosophy involves less attention to literary art. And in philosophy it is quite time we recognised how dependent he is on his predecessors. In so far as these early works are concerned, he is simply a Neo-Platonist, without theurgic excesses, and having in addition a Scriptural conception of the Incarnation and regeneration. The idea-world of Plato, the world of abstract and necessary truths, is the pivot of his speculations. It is no disparagement of Augustine to recognise this.

In the spring of 387 the group returned to Milan. Those who desired to be baptized at Easter had to send in their names at the beginning of Lent, when they began to count as competentes. In the course of Lent they were assiduously instructed in the Christian faith, and were examined from time to time on their knowledge and disposition. A passage in a later work of Augustine's seems to indicate that he was not exempted from these instructions and scrutinies; indeed, we know that St. Ambrose was particularly conscientious in the discharge of this duty. Still 


\section{ST. AUGUSTINE AND HIS AGE}

Augustine found time to continue his literary work. He wrote a work On the Immortality of the Soul, in which he developed, in a severe style of argument, the familiar Platonic proofs. Nourisson ${ }^{1}$ finds it regrettable that Augustine spent his time in reproducing some of Plato's feeblest arguments. Augustine himself never thought much of the work. He said afterwards that it was so obscure he scarcely understood it himself; it got abroad in an unfinished state, without his consent. Yet it is, as I said, closely and carefully reasoned, and there are thoughts in it which are still advanced by spiritualist philosophers; such as, the eternity of abstract principles, the inverse ratio of sense and mind development, and so forth. With all that, it is an unconvincing work, bearing so obviously the strain of 'the will to believe' and to make out a case.

At the same period he commenced his six lengthy books on music, which we shall meet later on, and a number of treatises on the minor disciplines-grammar, logic, rhetoric, geometry, and arithmetic. Only the work on grammar was completed, and was lost in travelling. The others remained in an imperfect state, and even these

${ }^{3}$ La Philosophie de Saint-Augustin. 
rudiments had disappeared before Augustine's death. The works on these subjects which circulated under Augustine's name during the Middle Ages are spurious.

On the vigil of Easter, the 24th of April, Augustine was baptized. The legend of the composition of the $\tau_{e}$ Deum by him and Ambrose during the ceremony is, of course, entirely discredited. ${ }^{1}$ There is no reason for thinking that Ambrose attached great importance to the accession. Augustine was young and unknown outside a narrow circle of friends and pupils. His son Adeodatus and Alypius were baptized with him. The long struggle was over; the hills of his vision were reached. He turned his back on the schools and the court, and set out for Africa.

1 Though Cardinal Rauscher does not hesitate to present it as historical. 


\section{CHAPTER VIII}

\section{RETURN TO AFRICA}

Os'ria, where we next meet Augustine and his friends, was not at that time the abandoned and fever-stricken ruin that we know to-day. It was a busy Roman watering-place, its marble quays and handsome villas brightened by constant visitors from the great city. Jaded lawyers and other officials used to drive down in the heat of the summer, and idle patricians counted it, like Baia, one of the places that Jupiter had marked out for relieving the ennui of patrician existence. It was also the port of arrival from and departure for Africa. Many a time when the corn ships from Africa were late, its quays were crowded with anxious Romans, scanning the southern horizon from morning until night. Augustine and his friends were resting there after the fatigue of the journey, and preparing to cross to Africa, when Monica contracted a fatal fever. 
A fine page in the Confessions and a painting by Ary Scheffer have immortalised the last conversation of Augustine and Monica. No doubt Augustine has somewhat etherealised and given a philosophic complexion to the discourse they held, leaning from the window over the garden of their hospice. Monica was an uneducated woman. Few women stand out from the crowd, as Jerome's pupils on the Aventine do, in that age of woman's emancipation. Moreover, there is reason to think Monica was of poor extraction ; Augustine describes her as being sent into the cellar to draw the wine every day in her younger days-and taking reprehensible sips on the return journey. But she was a woman of deep religious feeling and exceptional moderation of life. The Church has put many more disputable models of maternity on the roll of the canonised. She died at Ostia. Many years before she had prepared her tomb by the side of that of her husband at Thagaste. Now, in her joy at the generous conversion of her son, she expressed a complete indifference about it: 'Place this body anywhere,' she said, ' and do not trouble about it; I only beg that you will remember me at the altar of the Lord, wherever you may be.' They buried her at 
Ostia, and Augustine has written her simple but ennobling epitaph in the immortal pages of the Confessions.

With the moving description of the death and burial of his mother, Augustine completes the historical part of his Confessions. The four remaining books are devoted to a quite irrelevant and discursive treatment of all kinds of philosophic and religious questions. In the tenth book there is an elaborate argument for the spirituality of the soul founded on the power of memory. The long analysis of memory is one of Augustine's most notable pieces of psychological work. Although the root-thought, in this and in the dissertation on time in the following book, is borrowed from the Greeks, few who read the elaborate and ingenious development will feel inclined, with M. Nourisson, to deny Augustine any originality in philosophy. The twelfth and thirteenth books are occupied with the first chapter of Genesis.

In reading the Confessions it must be remembered that they were not written until about the year 400, or thirteen years after Augustine's conversion, and eight years after his ordination. They were written, that is to say, by the bishop of 
Hippo, the leading theologian in the Western Church. The two reasons which he assigns for writing them are hardly consistent; in one place he says that he wrote them in answer to a request from friends for a narrative of his earlier years, and in another that they were intended to moderate the enthusiasm of his admirers. Rousseau and Abélard, the other two illustrious literary penitents, are equally wanting in candour when they have to assign a reason for the heroic candour of their confessions. Abélard pretends to write for the consolation of a suffering friend, but very obviously has an interested aim. Rousseau sets out with a grandiose idea of 'describing a man in all the truth of nature'; after many pages the remark escapes him that so ugly a caricature of Jean Jacques is circulating in Paris and Geneva that he will probably gain by telling the whole truth, and so, as a German critic has said, 'he persuaded people he was virtuous by describing himself as vicious.' It must be stated that Augustine also had many enemies in 400, and serious calumnies were circulated about him in Africa, so that the Primate of Numidia had at first refused to ordain him.

Yet few will seriously question the unselfish- 


\section{I70 ST. AUGUSTINE AND HIS AGE}

ness of the Confessions. Certainly, we must not exaggerate the penitential value of the work. The one sin which it proclaims was already well known, both to friends and enemies. The truth seems to be that the book is a kind of theological treatise and work of edification. The bishop of Hippo takes the rhetorician as an 'awful example' of nature without God. To point his dogmatic antithesis of nature and grace, philosophy and Christianity, nothing could be more forceful than his own career, painted as darkly as conscience would permit. There was this subtle consolation for the writer that, if unregenerate nature is so impotent, its responsibility cannot be great in the absence of grace. Hence the theologian could dissect his dead self with calmness, and cheerfully send the work to his friends. But the fallacy of it all for us, reducing its value as a human document, is that Augustine examines his earlier life from a false point of view. We know how remote his earlier conduct was from the lofty ideal of his later years; but the real moral drama lies in its relation to his pre-Christian conscience. Thus the very altitude of the later ideal spoils the psychological interest of the Confessions. The penitent is face to face with God throughout, 
striving to maintain throughout the Divine point of view. Fortunately, he drops from the heavens occasionally, and mingles shrewd reflections, subtle speculations, and warm human discourse, with his narrative. They it is that have secured for the Confessions not merely immortality, but immortal interest.

After the burial of his mother, Augustine appears to have returned to Rome instead of continuing his journey to Africa. Tillemont, the great authority for dates and movements in his life, conjectures that he was deterred by news of the unsettled state of Africa owing to the campaign of Maximus. $\mathrm{He}$ therefore decided to remain at Rome until the struggle was over. We can well imagine with what new eyes he looked upon the life of the eternal city. He had never indeed entered into its gaiety, or admired its brutal pleasures and its dearly bought luxury. The change was chiefly in his religious outlook. He was no longer indifferent, or even cynical, with regard to its conflicting gods and rival altars. There was now a sun in his mental firmament, and he saw only what it illumined in life. The paganism of Rome he once more entirely ignores. It was not until a serious cry 
rang out of the pagan world after the fall of Rome that he turned to consider the old religion. The City of God is almost his first notice of the chief rival of Christianity. Probably the Church itself was less anxious about the old religion than it had been on his arrival in Italy. Prætextatus was dead; Symmachus had abandoned the contest. Jerome had ceased to compromise the Church with his imprudent letters. The law of 382 was quietly doing its work. In the West, under the strong Theodosius, temples were being levelled to the ground by the Christian people, led by fanatical priests and monks. At Rome the sacrificial fires were going out one by one for want of funds. In a few more years the bishops would find it opportune to advise Valentinian to close the temples and prohibit the old cult. Earnest religion was retreating to the Vatican, without the walls, where the temples of Christ and Mithra mingled their incense-fumes in significant proximity.

For Augustine the one great abomination in Rome was the small and obscure group of Manicheans. $\mathrm{He}$ at once opened a bitter and lifelong campaign on his old religion. ${ }^{1}$ By word

1 Personally I am disposed to see in this a quite natural, if not laudable, expression of zeal for truth and for the removal of what 
and style he pursued these 'barking dogs,' and whipped them for their 'most unblushing pertinacity' on every occasion. Two works especially were written against them by him at this time. The first, called On the Quantity of the Soul, is mainly directed to proving the spirituality of the soul. Its chief argument is, once more, an appeal to the characters of mathematical and other abstract truths. But it deals also with the questions of the origin and destiny of the soul. It is indirectly against the Manicheans, though it really consists of a series of dialogues he held with his friend Evodius on the questions raised. $\mathrm{He}$ also began about this time to write his work on Free Will. This also was suggested by Evodius, who raised the question of moral evil. Our sober Pelagius had not yet appeared in the Roman world with his heretical admiration of human nature, so that Augustine was quite free to throw the whole burden of moral evil on the human will. It was very simple: 'man had marred what God had made,' in the phrase which

Augustine now felt to be a superstition. But I have so frequently heard from reputable theologians and journalists that it is a grave offence against propriety and honour for a man to turn and rend the institution or sect he has just quitted that I leave the matter to these people. 


\section{ST. AUGUSTINE AND HIS AGE}

soothes so many minds to-day. The first book of the De Libero Arbitrio is an admirable Pelagian treatise.

But he makes a direct and unsparing attack on his late colleagues in the companion works On the Morals of the Church and On the Morals of the Manichees. It is clear (cf. 1. II. cxii) that these were not completed and published until he had returned to Africa. However, they were mainly composed during his stay at Rome, and so they reflect his mind and temper at that period. It is in these that he discovers 'the most shameless pertinacity' of his Manichean friends. The works are of little value beyond affording an indication that Augustine's mind is already hardening into intolerance. They are feeble in argument and poor in literary texture. The first is a plain, ineloquent description of the Christian ideal and the monastic fervour and model communities (such as that at Marcella's palace) which it has inspired. The argument is a challenge to the Manicheans to exhibit a similar inspiration. Had Augustine published this in Rome, his late friends would have smiled and pitied him. Jerome, who knew Rome, had already written (in 384) the letter to Eustochium in which, after a 
violent attack on the women and priests of the Christian community, he said that when they met a woman of unusual gravity and ascetic appearance in the street they at once concluded she was a Manichee. The second work is still more unfortunate. His attack on the dogmas of the Manichees is unanswerable. The idea of evil which he has learned from Plotinus cuts fatally to the root of their system, and it is an easy task to criticise them in details. $\mathrm{He}$ does not seem to realise, however, that much of his irony cuts two ways. 'Are we to find out God by the eye and the nose?' he scornfully asks, in criticism of the Manichean contention that the glory of the flower reveals the presence of divinity. But the poison is in the tail of the treatise, which consists of a petty attack on the Manichean moral ideal and a batch of malodorous scandals. This also was a questionable policy to adopt in face of Jerome's well-known letters. But the more serious circumstance is that Augustine's stories will not bear examination. Only five years afterwards he was publicly challenged by a reputable Manichean bishop, Fortunatus, to discuss 'the morals of the Manichees.' He tried for some time to evade the question, but at length was 


\section{ST. AUGUSTINE AND HIS AGE}

forced to admit that he had 'never seen anything wrong in the assemblies he was present at, and was not in a position to know what took place amongst the elect.' Probably Augustine little knew, when he began throwing stones, how fragile a house he had entered.

Towards the autumn of 388 peace was restored to the empire, and Augustine sailed for Africa. $\mathrm{He}$ and his friends intended to continue at Thagaste the community life they had enjoyed at Cassiciacum, but a point of some interest occurs in connection with a short stay they made in Carthage. They were detained by a friend named Innocentius. A year or two after this Augustine wrote his fine treatise $O n$ the True Religion, for the purpose of converting to Christianity his friend Romanianus, who tarried in an eclectic theism. The argument of the work is, naturally, wholly philosophical. There is a wise appreciation of the work of reason in establishing the preliminary truths of faith, seeing that, Augustine says, miracles are no longer wrought in its interest. In the Retractations Augustine wishes us to believe that he meant to say that 'the same miracles' are notı wrought in his day. No one who reads the De Vera Religione with an impartial 
study of its argument will admit this. And the most perplexing circumstance is that some of the miracles which he quotes from personal knowledge in the City of God were related to him during this stay at Carthage - two years before he wrote the $D e$ Vera Religione. We are forced to an interesting conclusion, which the hagiographer has overlooked; Augustine smiled at his host's miracles in 388 , and only learned to appreciate them years afterwards.

There is a further circumstance of some interest to those who are familiar with 'lives' of St. Augustine. They only relate two miracles, whereas Augustine gives three in the City of God. The omitted miracle happened to a physician, a feature which alone should secure for it honourable mention. The poor man was tormented by the demons because he was determined to be baptized; and one night, though he suffered from gout, a number of them came into his room in the form of little nigger boys and danced a prolonged dance on his feet. Like the miracle of the young woman of Hippo, who was cured by being rubbed with oil into which a priest had dropped a few tears, this interesting event, given on Augustine's authority, is generally neglected. Indeed, one of the two miracles usually given is far less impres- 


\section{ST. AUGUSTINE AND HIS AGE}

sive than it seems when one reads the whole story. Augustine asked the woman, who had been cured of cancer, why she had not proclaimed the miracle from the house-tops. She said she had done so ; but when he asked her intimate friends, they knew nothing of it. She finally excused herself on the ground that her physician had laughed at her story. The truth is that Augustine became a model of trustfulness in the acceptance of evidence. $\mathrm{He}$ admits the pagan miracles, narrated by Livy and Varro, etc., without a murmur ; they prove the existence of a devil just as surely as Christian miracles tell the power of God.

But we are dealing with Augustine in 388, when reasoning has not yet totally ceased to be his 'darling.' From Carthage we must follow him to Thagaste, where the new community was to be established. The house which his father had left him in the outskirts of Thagaste became a monastery. The transformation of the Epicurean idea was now complete. He had the daily fellowship of his friends, it is true, but there was no longer any difference of opinion about woman. No woman, not even Augustine's sister, was allowed to live under their roof. They still talked reverently of Plato and Pythagoras, as of men 
through whom God had shown the faint dawn of the Christian revelation. But in the affairs of this world they had no part. The only news from Rome that interested them was that another senator, Paulinus (afterwards of Nola), had embraced Christianity and deserted the empire ; that the prefect of Rome, Gracchus, the prefect of Gaul, C. Postumus Dardanus, and the senator Pammachius, had abandoned the old religion. To the material dangers that were gathering thick about the empire they were supremely indifferent. It was the life beyond the grave that mattered; this world was but a stage, set with death-traps on every side, on which the Christian must play his part warily. The love of woman or child, the breath of wine, even the perfume of the rose and the gladness of song (Confessions, $\mathrm{x}$.), were snares cunningly set-whether by kind or hostile hand they could not say. Alypius and Evodius were with him from the first. Nebridius returned to his home near Carthage, where he died shortly afterwards. Romanianus declined to follow him into Christianity. Licentius roamed out into the wide world, in search of pleasure and poetry and honour. But Augustine sold all his property, except this house, and thus endowed his 
monastery, so that very shortly he gathered a number of converts about him.

This was the foundation of the Augustinian order, the cradle of the monasticism of the west. Not that Augustine had any idea of founding what we now call an 'order' or a peculiar institution. It was not until 1246 that the scattered communities of 'Augustinians' were gathered into a fully organised body under a general. But in the meantime the 'rule of St. Augustine' had inspired the great order from which so many others descended. The Donatists in later years accused Augustine of being the founder of monasticism in Africa ; I say 'accused,' because it was not many years before Africa was overrun by a vagabond tribe of hypocrites and fainéants, whom Augustine himself was frequently forced to attack. Augustine was not, however, the parent of the idea, as we have seen. It had been introduced into the west by the Egyptian monks who accompanied Athanasius, and had been zealously propagated by Jerome, who sent fiery letters and eloquent lives of the hermits from his own retreat. It was in Italy that Augustine learned the idea; though, it will be remembered, he had always shown a leaning to the cenobitic model. 
Unfortunately, Augustine had more zeal than discretion in propagating the monastic life in Africa. In the democratic feeling which had come upon him he demanded that the doors of the monastery should be opened wide to the whole world. No one should ask even for a token of religious purpose in the aspirant. Labourers from the fields, slaves, and others of the lowest classes, were to be admitted without a question, ' even if they give no proof of a change of life.' 1 Pious masters and mistresses were exhorted to free their slaves whenever they desired to enter a monastery. The result was that the monasteries which soon sprang up like mushrooms on every side were flooded with slaves, cunning, hypocritical, and sensual idlers. We shall see in the course of our study that, side by side with the finer characters who were given to the Church by Augustine's monasteries, there were a number of black sheep living under his very eyes for years. In the Egyptian deserts, no doubt, there were plenty of the idyllic communities which charm us in the pages of Mr. Kingsley's Hypatia and M. Anatole France's Thais. It was very different in North Africa, where the hot breath of the cities was not

1 De Opere Monachorum, c. 25. 


\section{I82 ST. AUGUSTINE AND HIS AGE}

warded off by long miles of desert land. There was this important difference, too, that Augustine's ascetical ideal was moderate. It was the ideal of a philosopher. Provided the chief luxuries of life were sacrificed, and the will was strengthened by a sober diet and an occasional fast, he did not see the need of inflicting so much positive self-torture. Whilst Jerome was gashing his naked breast with stones in his Syrian hermitage, Augustine was quietly taking his plain dinner and cup of wine at his neatly appointed table. Whilst Jerome exaggerated the sterner counsels of Christ, Augustine attenuated them. In one of his sermons (No. IOI), he explains, in a pleasant way, what Christ meant by forbidding His disciples to carry purses, wear shoes, and so forth. 'Lord,' he says, "Thou didst suffer a theft in Thy company: what hadst Thou that the thief might take from?' So the 'purse' must mean 'wisdom closed up,' not a bag of money. In the same way shoes, or ' dead skins,' mean 'dead, or unregenerate, works.' It is intelligible, therefore, that the African monasteries should offer a comparatively agreeable retreat for the driven and despised slave, who had as much chance as any other of becoming superior, and the overworked agricultural labourer. 
In about ten years Augustine had to write a work in criticism of the army of monks he had created. We may resume the question when we come to that period.

But one further point calls for notice at the present stage. Augustine very quickly learned an uncompromising zeal for withdrawing people from the world. We have seen how Jerome urged men to push aside a heartbroken mother, and tread over a prostrate father, in order to fly to the desert. We like to conceive Augustine as pre-eminently sober and humane in his religion; but it must be admitted that in this, as in at least one other point, his humane feeling was overruled. There are passages in his writings which rival Jerome's heroic advice. Thus in a letter (ep. 243), to a man named Laetus, he says, in urging him to disregard his mother's prayers that he would not abandon her: "What does it matter whether it be in the person of wife or mother, since we have to beware of Eve in every woman ?' Already the city of the world, with all the affections and ambitions that brighten its momentary life, was becoming contemptible, as the vision of the city of God grew in his mind.

It was impossible to relate the founding of 


\section{I84 ST. AUGUSTINE AND HIS AGE}

Augustine's monastery at Thagaste without a hint, at least, of what that tiny seed contained. But during the three years which followed Augustine's return to Africa there was no indication of the alarming growth which was soon to appearalarming even to the sower of the seed. During those three years Augustine and a few companions prayed and read and talked, with no definite thought of the future. They awaited death, their supreme goal in this life. In the meantime they shut out the distracting life of the world from their home as completely as possible. In the course of time, as appears from a letter to Nebridius, the citizens of Thagaste constituted Augustine a kind of informal magistrate and councillor, but he was always impatient of their secular affairs. His chief concern was controversy. He wrote, or commenced, a number of works at this time, besides maintaining a busy correspondence. It was at Thagaste that he wrote the Treatise on the True Religion, which I have quoted previously. This little treatise is not only the most carefully written of Augustine's works, but it also illustrates in a peculiarly interesting way the transitional theology he held at the time. It was written for the purpose of converting his wealthy friend, 
Romanianus, who had, we gather, remained in an eclectic frame of mind, favouring Christianity, Platonism, and Manicheeism. I have already told of the denial of miracles which he afterwards explained away. ${ }^{1} \quad$ Another section which gave him some uneasiness in after years was that in which he meets the Manichean difficulty about moral. evil. The Manichees explained it with their usual facility; there was a bad soul as well as a good soul in man. Against this Augustine urges that moral evil is wholly traceable to man's free will. In later years the Pelagians searched these early works of Augustine's to good purpose. The finest part of the work, however, is that in which he contrasts Platonism and Christianity, very much in the spirit in which $\mathrm{Mr}$. Kingsley has contrasted them in our days. $\mathrm{He}$ is still full of admiration for the Platonist religion (into which, I must admit, he reads a certain quantity of Christianity), but he insists on the powerlessness of Plato and Socrates to touch the masses. With them religion was necessarily an aristocratic concern. Christianity has spread the finest elements of Platonism in every grade of society. Also,

1 In the same treatise he rejects all cultus of saints or martyrs :Non sit nobis religio cultus hominum mortuorum. 
Socrates and Plato, he says, connived at the popular polytheism through fear; Christianity faced it, with the strength of a Divine foundation and Divine example. The work is a fine expression of a rational and humane theology, making one almost wish Augustine had never known the fatal dignity of the episcopate, with its flood of work and its insinuating interests. Romanianus responded to the appeal, and became a Christian.

It was also about this time that he commenced his long and anxious labours on the interpretation of Genesis. It was the Manichean criticism which prompted his concern to rationalise the puzzling narrative, and the first attempt to deal with it was a small work On Genesis: against the Manichees. It reproduced in a simple style the arguments he had urged in his more scholarly $D e$ moribus Manicheorum. But its allegorical treatment of the Genesiac legends did not please him long. A few years later, convinced that Genesis was in accord with the physics and astronomy of the day, he ventured upon his De Genesi ad Literam. His ingenuity broke down, however, and the work remained unfinished until about the year 400, when he wrote his large commentary on Genesis ' to the letter.' 
These works form a monument to Augustine's courage and ingenuity. But one reads them with a feeling of pity now that Mr. Sayce and other reputable scholars have told us whence these stories were copied.

He then completed his work 'On Music', a very curious work, showing a bewildering knowledge of the teaching of the time under that head. The first five books deal in a dry and technical way with the definition of music, rhythm, metre, and verse. In the sixth book he suddenly rises to a Pythagorean height of theology. In later years, when a bishop had asked for a copy of this work, he replied that he would send one if he could find one, but he rather hoped he could not. His letters to his friend Nebridius, written at this period, also contain some points of interest, and bring out the more human side of Augustine. He has not yet forgotten how to make jokes, and he has shrewd suggestions still in matters of secular knowledge. Thus, when Nebridius asks why the sun is larger than the stars, Augustine prophetically raises the question of their relative distance from the earth. A letter to a grammarian of his old school-town, Madaura, elicits an answer of less pleasant interest. Maximus had written to plead, 
in a polite and amiable way, the cause of the old religion, but Augustine returns a very harsh reply, making a bitter and contemptuous attack on the poor Olympians.

Towards the end of his stay at Thagaste, he lost his son, Adeodatus. Augustine says he had long been alarmed-'horrified,' he says-by the boy's precocious intelligence, and no doubt the daily contact with Augustine's philosophic friends and constant presence during their discussions had greatly advanced his development. We have an interesting proof in the little work of the Master, a dialogue between the father and son, leading up to the words of Christ, 'One is your Master.' Augustine assures us that the words assigned to Adeodatus are faithfully recorded, and they show a good deal of cleverness and thoughtfulness.

Augustine spent three years in his retreat at Thagaste. It would hardly be profitable to speculate on the probable development of his thoughts if he had remained throughout life in this tranquil and leisurely condition. It was impossible that he should remain long in his monastery. The African Church was in pressing need of competent ministers. Few of its bishops had any distinction 
for learning or any other impressive quality; and, owing to the monopoly of the chief functions (such as preaching) by the bishops, there were no priests of ability, apart from the few who awaited the vacant sees. The bishop rather corresponded to the modern vicar or curé; the few priests who were attached to each (save in such a town as Carthage) representing his curates. Hence there was an inordinate number of bishoprics in the struggling African Church, and a constant observation was maintained for desirable candidates. At Carthage, moreover, Augustine had met an energetic young deacon, named Aurelius, who had since become bishop of that place. It was not long before many covetous eyes were bent on the monastery of Thagaste. Augustine had to move about with the prudence of a debtor whenever he left his monastery. He remembered the story of Ambrose's election, and the extraordinary means by which he had fruitlessly tried to evade the office thrust on him. The congregations of the fourth century were not easily disconcerted when they had chosen a priest or bishop. Bishop Synesius of Ptolemais-familiar to readers of Hypatia - vainly pointed out that he was a heretic, and married to boot, when the people demanded 


\section{ST. AUGUSTINE AND HIS AGE}

his consecration. Augustine had to decline many insidious invitations to visit towns or villages where a bishop was required.

It was in 39I that Augustine was at length captured, and pressed into the service of the Church. A government official of Hippo (now Bona), on the coast, had expressed a willingness to retire from the world if Augustine paid him a visit. It is difficult to say whether this was a pious stratagem of the Hipponenses or not; but, as the church of Hippo had a bishop living, and there seemed so excellent a prospect of securing a convert, Augustine indiscreetly set out for Hippo. The story told by Possidius, Augustine's pupil and biographer (for the later period of his life), introduces us at once into the simple church-life of the early centuries. One day, whilst Augustine was listening to the sermon of Bishop Valerius, that prelate seized the opportunity to remind his congregation that he was getting old, and needed a priest to share his work. ${ }^{1}$ There was immediately a loud demand for Augustine. He begged

1 Hatzfeld (Saint Augustine), with the usual licence of the hagiographer, graphically describes how the people dragged him to the bishop when they learned he was in town. The story of Possidius is interesting enough, without this kind of adornment. It is not unlike Villemain's statement that Symmachus sent for Augustine at 


\section{RETURN TO AFRICA}

and protested and wept, but to no purpose. The people were not accustomed to resistance in such matters, and they certainly never yielded to it. Augustine had to consent.

The reader who is unfamiliar with the ways of the early Church may have some difficulty in picturing such a scene, so quiet and submissive is the modern congregation to its pastors. It is true that the people are still consulted as to the quality of those who are to be ordained, but few are so rude as to take the prelate at his word and answer the questions he puts from the altar; the wiser and more reverent liturgy of the Church of Rome directs the putting of the questions to the people in Latin. In the fourth century the proceedings were less stately. The great preacher was encouraged by rounds of applause at the end of his well-turned periods. The less gifted preacher was liable to be reminded of the progress of the water-clock. Augustine tells a story (ep. 7I) of a bishop who, having pretensions to learning, quoted Jerome's translation of Jonas iv. 6 in his sermon. The people missed the Rome when he had to choose a teacher for the Milanese; or the Duc de Broglie's discovery that Augustine helped to guard Ambrose in the church at Milan. Another prominent hagiographer depicts Augustine's 'amazement' when the people demanded his ordination. 


\section{ST. AUGUSTINE AND HIS AGE}

familiar 'gourd' (for which Jerome had substituted 'ivy'), and protested at once. After some altercation the bishop appealed to the Jews, who maliciously sided with the people, and the poor bishop had to retract. ${ }^{1}$ We shall see many instances of this lively interest of the early Christians in the affairs of their Church. There was no 'real presence' to restrain their expressions, nor law against 'brawling.' When Augustine relates that his mother went to church every day, he is careful to add that she did not go for the purpose of gossiping. Jerome says that the church was only second to the doctor's shop as a resort for gossips at Rome.

Augustine claimed some time for recollection and preparation for his new office. $\mathrm{He}$ was as sincerely distressed as Ambrose had been by the choice, but did not imitate his desperate efforts to escape. After a few months' preparation he seems to have assumed the priestly order and commenced his new duties about Easter 39I.

1 Of another man who complained to Jerome of the change he had made the saintly cynic said : "The fellow was afraid he would have nothing to take a drink from on the sly, if ivy grew instead of his gourds.' 


\section{CHAPTER IX}

THE BISHOP OF HIPPO

Hippo-' Royal Hippo,' as it was called, to distinguish it from Hippo Zarytus (Bizerta)-was an interesting little town in the days when Augustine went to reside there. Its title recalled the slender glories of the ancient kings of Numidia, who found it an agreeable winter residence. Under the Romans it had grown into a flourishing seaport, the most important on the north-western coast after Carthage. Connected with all parts of Numidia and the other provinces by a chain of Roman roads, it had become the chief outlet for African produce and an important gate into Africa for the Romans. When the Vandals swept over the land, Hippo and Carthage alone withstood them for any length of time, Hippo keeping them at bay for fourteen months. It has shared the utter desolation that has fallen upon north-western Africa in the train of the 


\section{ST. AUGUSTINE AND HIS AGE}

A rab conquest. To-day it is a formless mound of ruins, over which nature has spread a kindly veil of vegetation. But one of Hippo's glories still lives in the midst of this desolation. On Fridays the neighbouring Arabs gather at a certain spot amongst the ruins, to sacrifice birds, and fire their rifles, and offer other uncouth tokens of an unusual veneration. And when you ask them the story which lies at the root of their strange tradition, they can only tell you vaguely that once a great 'Roumi' (Christian) dwelt in that spot.

Hippo was a colonia in the Afro-Roman empire. It was situated about a mile from what is now called Bona, on one of the lower plains of Numidia, between the rivers which the Arabs call the Seybouse and the Abou-gemma. The rivers formed its northern and southern fortifications, whilst stout walls drawn from river to river protected it on the east and west. The Romans seem to have deepened the channel of the Seybouse from the town to the sea-a distance of about a mile-and the shipping moored at the quays on the south of the town. To the east was the broad blue expanse of the Mediterranean, whilst in the rear of the town the horizon was closed by a series of luxuriantly clothed hills. The space 
enclosed by the walls and rivers was about one hundred and fifty acres, but a large part of it was probably taken up with gardens. It was, however, pleasantly dominated by a softly-rounded hill almost in the middle of the town, which was crowned by the citadel. At the north-east corner was a fine Roman bridge over the river, which still survives, and the castle or fortress of the military,

But though the town had probably a population of between thirty thousand and forty thousand inhabitants, it was a poor, ignorant, and scanty congregation that had thus secured the great gifts and greater promise of Augustine. The pagans were evidently in the majority there in the closing years of the fourth century, if not at the close of Augustine's career. We cannot find that the Catholics - the name was already in use-had more than one basilica in the town. The Donatist Schismatics had another, if not more than one. The remainder of the townsfolk were either pagans or Manicheans; and as the Manicheans were a somewhat select and cultured body, the vast majority of the people must have still followed the religion of their fathers. There cannot have been more than a few hundred worshippers in 


\section{ST. AUGUSTINE AND HIS AGE}

the 'basilica pacis,' where the Catholic bishop, Valerius, was the sole ministering priest; and these must have belonged mainly, as we may infer from Augustine's sermons, to the uneducated class. Fishermen, labourers from the quays and from the outlying estates, and slaves, must have made up the bulk of the congregation. Indeed, when Augustine had protested, with tears, against his ordination, many thought, says Possidius, that he felt the littleness and poverty of the position they offered him. We may be sure there was no such thought in Augustine's mind. One human feeling we do seem to detect in his reluctance; he admits somewhere that the prospect of the violence of the Donatists counted for something in his distress. That was a pardonable feeling, as will be apparent later on. But his resistance would undoubtedly have been greater if the See of Carthage had been offered to him. And when he did eventually submit to ordination, it was with the one thought that he was entering upon a sacred duty.

Bishop Valerius was a Greek, and an old man. His knowledge of Latin had always been defective, and it was with some relief that he handed over his chief functions to Augustine. Brother bishops 
were scandalised, and Valerius had to invoke the custom of the Eastern Church in support of his action. In the west a priest was never permitted to preach in the presence of his bishop, and the latter always reserved for himself the preparation of the competents and their baptism. I have said that the priest was only a kind of curate to his bishop. It must be understood that he was, as a rule, only intrusted with the duties of what we would consider a very minor curacy. The number of Christians was so small that the bishop usually found it possible to do all the preaching and baptizing in his parœcia. ${ }^{1}$ Hence, although the 'parish' sometimes had an ample territorythat of Hippo extending for some forty miles-it rarely numbered very many souls, and it is entirely misleading to give the number of African bishops as an indication of the Christian population. ${ }^{2}$ There were probably about five hundred Catholic bishops in the diocese of Africa at the end of the

1 The word 'diocese' was then applied to a large division of the empire, such as north-west Africa.

2 For instance, one is impressed at first by the statement that there were 748 bishops (Donatist and Catholic) at the great conference at Carthage in $4 \mathrm{I}$. But, on the other hand, we cannot find that there were more than some twenty or thirty missions in Augustine's own parcecia (and this after the 'conversion' of the Donatists) at the close of his career. 


\section{I98 ST. AUGUSTINE AND HIS AGE}

fourth century. Though they murmured at the concessions of Valerius at first, they began to imitate him when they saw the success of the change; and the Eastern custom was finally adopted throughout the West.

Augustine's first care after his removal to Hippo was to found a new monastery. Valerius gave him a garden which was attached to the church, and here he built his monastery. Alypius and Evodius seem to have joined him, and a number of others was admitted into the community. There are indications that Augustine made the mistake of admitting youths at an immature age; curiously enough, the only one of his monks whom he mentions expressly as having been brought up in the monastery 'from his early years'-a troublesome young man of the name of Antony, whom we shall meet laterturned out a black sheep. We shall have to record a number of minor scandals that troubled the peace of the community, but there is no doubt that the monastery at Hippo rendered invaluable service to the African Church. No less than ten of its most zealous bishops were taken from Augustine's community. Other bishops were moved to build seminaries of this kind, and 
thus a more spiritual body of men were secured for the ministry. We shall presently find Augustine founding a seminary, properly so called; but until that date the supply of priests and bishops was precarious.

But when Possidius says that from the day of Augustine's ordination 'the African Church began to lift up its head,' he is regarding his master and friend in the character of a controversialist. Augustine flung himself at once into. the work of proselytising. Hitherto the Catholics had lived on sufferance at Hippo, and for many years to come the civic officials slighted the struggling community. Augustine quickly altered the position of the Catholics. His earlier sermons show some sign of preparation and rhetorical finish, though he soon ceased to pay any attention to their literary quality. But he soon began to exhibit the two gifts which rendered such remarkable service to the Church of Africa-his power as a debater and as a controversial writer. In the year of his ordination he wrote a new work against the Manicheans. The De Utilitate Credendi is a carefully-written constructive treatise, and it is marked by a moderation of feeling and expression which Augustine's ardent temperament 
rarely permits. It is interesting, chiefly, for its indication that his views as to faith and reason are rapidly developing in the direction of his famous fides precedit intellectum. The fallacy of it is the familiar error of exaggerating the function of the moral dispositions connected with the act of belief and attenuating the moral duty, or the common-sense duty, of weighing the immediate authority for the propositions which claim the allegiance of the mind. Augustine's development on the question of faith and reason was uneven. He had a number of maxims instead of one consistent principle. When he is making a rational criticism of the Manichean dogmas, as in his Contra Epistolam Manichei, he triumphantly demands the proof of their cosmic assertions. When, on the other hand, he is urging the acceptance of Christian teaching, he says: 'Let us have no disputing; the will of God requires faith, not questions.' ${ }^{1}$ This habit of mind is already forming in the treatise 'On the Usefulness of Faith,' which is an attempt to disarm the rationalist inquirer, addressed to a Manichean friend. It was quickly followed by the $D e$

1 Sermon 318, where he is introducing the relics of St. Stephen, and some cautious person wants to be sure they are the remains of that martyr. 
Duabus Animabus, a direct attack on the Manichean doctrine of the two souls. In this Augustine is unanswerable, and he is still temperate in his expressions.

In the following year Augustine commenced his long and interesting career as a public debater. The Manichean religion, so philosophic in form, had made considerable progress amongst educated people, who looked with some disdain on both camps of Christians - the Donatists and the Catholics. ${ }^{1} \quad$ At Hippo they had a bishop named Fortunatus who had hitherto, it seems, been master of the field. That did not imply a very great mental superiority in a town which, Augustine says somewhere, could not boast the possession of a single copy of Cicero. However, it soon became apparent that Augustine was a match for the Manichee, and the Christians hastened to arrange a duel. Both Donatists and Catholics pressed Augustine to meet him, and he consented. They then approached Fortunatus, who hesitated

1 It may be useful to anticipate the fuller treatment of the schism to the extent of giving a definition. The Donatists were the followers of Donatus, who had separated from his fellow-Christians because they took, as he thought, a laxer view of certain defaulters during the last persecution. Half the Christians of Africa were Donatists ; but their opponents called themselves the 'Catholics,' as claiming to be in communion with the rest of the Christian world. 
202 ST. AUGUSTINE AND HIS AGE

for some time-Possidius says he had known Augustine at Carthage, and did not love the temper of his weapons-but consented at length, and the preliminaries were settled.

The contest was held in September, 392, in the baths of Sosius. A crowd of students and worshippers of all three parties gathered in the hall. The public notaries were summoned, and the dialectical battle raged all day. It was renewed on the following day, and Augustine gained an undeniable victory. Intellectually, Fortunatus was immensely inferior to Augustine. We still have the shorthand report of the debate, and can follow the feeble and shifty efforts of the Manichee to parry Augustine's criticism. In the end he completely broke down, and said that he would have to consult the more learned defenders of his belief on the points Augustine had raised. It is of some interest to notice that the chief of these points is the one which young Nebridius had fruitlessly urged on Augustine in his own Manichean days. Fortunatus set out immediately on his search for a more valid defence. He never returned to Hippo. It was a severe blow

1 But he had virtually to retract his earlier attack on 'the morals of the Manichees,' admitting that he knew no evil of them. However, see a later development in chap. xvi. 
for the Manicheans, who began to diminish in Hippo from that day.

The rejoicing of the Donatists was, however, very shortly arrested. Augustine soon adopted the orthodox view of the schism, and turned his weapons upon it. His first anti-Donatist document was a model of brotherly litigation with his 'separated brethren.' It is a letter to a Donatist bishop, Maximinus, written in an admirably temperate and reasonable spirit. But it was not long before he began to taste a little of the bitterness of the controversy. He wrote a kind of ballad, putting the Catholic points against the schismatics in popular and strong phraseology. It runs over the history of the struggle, and repeats the essence of the Catholic charge every few lines by a refrain which rhymes ' rebaptizare' with 'altare contra altare.' Probably the streets of Hippo had rung with such ballads often enough before. It is a wretched piece of doggerel with no literary pretension whatever. But if the irritation of your adversary is a point in controversy, it must have been effective. It was followed by a work 'On the Letter of Donatus,' which we no longer have.

But Augustine was not the man to be deterred 
by popularity from sternly denouncing the shortcomings of his own congregation. $\mathrm{He}$ is as earnest and uncompromising in his basilica as when he faces a heretic or schismatic. Perhaps the best illustration of his earnestness and power as a preacher is found in his suppression of the letitice, or feasts in honour of the martyrs, which have been mentioned previously. The permission to hold these feasts over the tombs of the martyrs was one of the most unfortunate concessions that the bishops had made in their eagerness to secure nominal converts. There were, assuredly, many Christians who took a purely religious view of the celebration, as we have seen in the case of Monica. But the abuse of the custom was undeniably grave and widespread. The churches were thronged all day with men and women who emptied their bottles-and those of sober folk like Monica-recklessly. ${ }^{1}$ That the clergy were far from uniformly opposed to the custom is clear from a canon of the Council of Hippo (a General Council of the African Church,

1 An effort is made by some ecclesiastical writers to transfer the orgies from the churches proper to adjacent buildings where the martyrs' bodies were kept. Not only were these memorice martyrum real chapels, but both Ambrose and Augustine make it perfectly clear that the ordinary basilica was given up to the people. 
held in 393), which forbade the bishops and priests to take part in the festivals. Moreover, the custom was extending to other festive occasions, such as the funerals of the wealthy. St. Paulinus of Nola writes approvingly of the giving of such an epulum sacrum at Rome. ${ }^{1}$

The custom had been suppressed at Milan and other places, but the Africans clung to it with great obstinacy. However, in 395, Augustine determined to make a strong effort to break the tradition. About the beginning of Lent occurred the feast of St. Leontius, the patron of Hippo, whose anniversary was always celebrated with great Bacchic fervour both at the Catholic and the Donatist basilica. A few days before the feast Augustine opened his campaign with an eloquent sermon on the viciousness of the custom. There were few people present, but these spread a report of the sermon, and a large number came

1 Old St. Peter's witnessed sights hardly less curious than its successor witnesses to-day. Sacred banquets were often held in it, and Jerome gives many another profane spectacle. He tells in one letter of a wealthy dame who ran down the long line of Christian mendicants with her gifts, and who, when an enterprising old lady had doubled back to get a second coin, promptly felled her with a blow. The murderous conflict which accompanied the papal election in 366 , when one hundred and thirty corpses were left on the floor of one basilica, occurred elsewhere. 
to hear him on the following day, when he again vigorously denounced the practice. His hearers wept, and Augustine himself was moved to tears, as he wrote afterwards to Alypius. However, he was told that there was still a strong group of obstinate feasters, who were resolved to hold the celebration as usual. On the morning of the feast he came to the basilica with a carefully prepared denunciation of the custom, and a resolve to 'shake his garments of them and abandon them ' if they continued their opposition. Fortunately, the leaders of the obstinate party came to discuss the matter with him, and were persuaded to desist. There was great rejoicing, of a purely religious order, in the basilica all that day. The prepared oration was set aside, and Augustine gave them an impromptu address, in which he naively explains how these festivals were a concession to the early 'converts' from paganism ; and he has also to explain away the evil example of the Church of Rome. And when the sound of rejoicing comes from the Donatist basilica down the street, he points out to his sorely tempted people how far superior is their spiritual celebration. They remained all day singing hymns and psalms in the church, and the agape were never 
again celebrated at Hippo. But Augustine had to contend frequently afterwards against the practice in other parts of Africa. In sermon 3 I I he speaks of the people dancing and singing all night in the chapel of St. Cyprian at Carthage. In another of his sermons he speaks of having incurred, probably at Carthage, great personal risk for his denunciation of the popular festivals.

About this time, also, Augustine wrote the work On Free Will, which proved such a treasure to his Pelagian opponents in later years. The first book had been written at Rome, and consisted of a series of conversations with Evodius. In the early years of his Christian development Augustine was constantly recurring to the question of evil. There was not a shade of mystery in it after he had read the Neo-Platonists, and he was ever eager to communicate his pleasant view of life. The work on free will is another effort to deal with it on the same lines as his previous works. Moral evil comes from man; what we call physical evil is not evil at all. The sufferings of human beings are a just punishment for sin. The sufferings of children cannot be rightly judged, since we do not know what God has prepared for them hereafter; in his Retractations 


\section{ST. AUGUSTINE AND HIS AGE}

Augustine had to express regret that he had spoken with some hesitation of the damnation of unbaptized infants. The sufferings of animals are a necessary part of the beautiful machinery of the universe; $M$. Nourisson is driven to qualify his remarks on this point as 'des mots vides de sens, ou même des sophismes pernicieux.' And when Evodius asks why God gave free will, since it is the source of half the evil of the universe, Augustine is no less optimistic. The universe would have been sadly imperfect without the presence of free will. In a word, there is no mystery whatever about the world. It reflects the wisdom and the love of God on every feature. It is just such a world as we should expect to find on the Christian theory of the divine nature.

In thus basing his argument so largely on free will, Augustine was undoubtedly running counter to the position he was to take up in later years. It was fortunate for him that he had completed his task of explaining moral evil to the Manicheans before he began to reduce the human will to an automaton in his opposition to the Pelagians. In these earlier years 'grace' is rarely noticed in his writings, and then is only conceived vaguely as an additional force, a kind of moral luxury. The 
human will is the central fact of the moral order. Augustine's earlier works against the Manicheans would have been impossible if he had then held the theory of grace which he adopted later. The Pelagians appealed particularly to this work on Free Will to prove his inconsistency, and they were certainly justified. It is a mistake to suppose that the later idea of grace was developed only under the pressure of the Pelagians. We can trace its growth before the appearance of Pelagius. But we cannot grant Augustine that the later thought is quite in harmony with the earlier. The theology and ethic of the De Libero Arbitrio, apart from its optimist excesses, would be accepted by most of the liberal theologians of our day-by men who shrink in pity from the theories which Augustine held twenty years afterwards.

Thus, between writing and preaching, Augustine was rapidly winning a high reputation throughout Africa. In 393 the General Council of the African bishops had been held at Hippo, and Augustine had been charged with the duty of preaching a special sermon before the assembled bishops. It became necessary once more for him to take precautions whenever he left his town. There was, in fact, a twofold reason for discre- 
tion. On the one hand the Donatists were greatly embittered against him, and to fall into the hands of the roving fanatics who conducted the physical side of the controversy for that sect would probably mean death. It is said that before long the bishops of the sect declared that the man who killed Augustine would gain a plenary indulgence of his sins. That is quite in keeping with what we know of the religious quarrels of the day. At all events, it would not be pleasant even if he escaped with a copious draught of vinegar and salt-water, or some similar experience of the controversy. On the other hand, many towns were eager to secure him for their bishop. He had again to move abroad with the forethought of a debtor at large. His fine theory of free will would count for little if he fell into the hands of any congregation that needed a bishop. On one occasion, indeed, some enterprising paracia seems to have sent a few of its members to Hippo for the purpose of kidnapping him, for we find that Valerius was obliged to conceal him for a time.

However, the bishop was forced at length to attach him to his church by a firm, if somewhat irregular, bond. At that time a canon of the 
Council of Nicæa forbade a bishop to have a coadjutor, but the African bishops do not seem to have been learned in the canon law. Valerius, therefore, had Augustine ordained bishop. Towards the close of 395 the primate, or senex, as he was then called, of Numidia, Megalius, bishop of Calama, came to Hippo with a number of other bishops, and Valerius asked him to perform the ordination. A curious incident arose which gave Augustine some trouble in later years. Megalius refused at first to ordain him on account of some calumny that was in circulation about him. It seems (Contra Cresconium, iii. 92, iv. 79) that the Donatists accused him of having given a philtre to a woman of Hippo. The story was, of course, a ridiculous invention of the Donatists, and Megalius was soon persuaded of that. But the letters in which he had stated his grievance afterwards fell into the hands of Augustine's enemies, and were used with much zeal by the Donatists and Manicheans for some years. Megalius publicly begged Augustine's forgiveness for his hesitation, and the ordination took place a little before Christmas. Possidius says that Augustine had a suspicion at the time that the ordination was irregular, but he was 


\section{ST. AUGUSTINE AND HIS AGE}

overborne. When he became assured of it afterwards, he had a resolution passed at the Council of Carthage, directing that the canons of the Church should be read to every priest before his ordination.

Augustine was now free to enlarge the sphere of his work. The jealous Hipponenses had hitherto rarely allowed him to visit other towns, but now that he was secured to their Church they gave him greater liberty. Possidius says that he began to preach frequently in neighbouring towns, and to challenge Donatist and Manichean champions to debate. As, moreover, Valerius died soon after his ordination, he became the sole bishop, and regained control of his movements. But the change brought him a multitude of new functions, many of which had been of little consequence under the old bishop. He had to remove from his monastery to the episcopal house. One of a bishop's duties was hospitality, he said, and this would be inconsistent with the quiet life of a monastery. He accordingly left the monastery in the garden to his associates, and removed to the house Valerius had left him. Let us try, in a fresh chapter, to form a picture of the life of a busy bishop of the fourth century. 


\section{CHAPTER X}

THE DAILY TASK

WHEN we are told that 'the whole of the cathedral clergy' consented to live in the bishop's house with Augustine, we must guard ourselves against large impressions. Probably one or two of his fellow-monks joined Augustine in his new home, though Alypius had already left him to become bishop of Thagaste. In addition to these, it is hardly likely that he had more than one or two deacons. There is no reason for thinking that he had any priests ministering under him in Hippo at that time. Twenty years afterwards his little 'seminary' included only about a dozen priests and deacons, as we know from the sermon (355), in which he discusses them before his congregation when a scandal has arisen. In 395, and for some years after, Augustine must have had nearly the whole burden of the ministry on his shoulders. When we realise the magnitude of that burden, 


\section{ST. AUGUSTINE AND HIS AGE}

we shall be in a better position to judge the literary and controversial work of the bishop.

Possidius gives us an interesting picture of life in the episcopal house, which he himself shared for many years. All things were held in commonor were supposed to be ; for in after years Augustine found that most of his subordinates had quietly retained possession of houses, or slaves, or other property. Still, in the practical administration of the house, the right of private property was not recognised. All food and clothing was handed in to the common store, and distributed according to need. In one letter Augustine acknowledges receiving a shirt from a lady of Carthage; in another, a warm cloak. He was careful to choose only the more common for his own use; lest, he says, people should complain that his priestly office brought him luxuries which neither his family nor his profession would have procured for him. The common table offered little beyond bread and vegetables; meat was reserved for visitors and for the sick. Yet he had an Aristotelic idea of moderation in his virtue. Wine was allowed to the extent of two or three cups each, a fine of one cup being imposed for relapse into the African frailty of swearing. Silver 
was admitted in the matter of spoons; all other utensils and vessels were of marble, wood, or earthenware. Augustine would have us think that he suffered from a besetting tendency to excess at table. Bayle, of course, has pleasantly enlarged on the phrase in the Confessions (x. 3I), in which he makes the admission; but Bayle is entirely wrong in applying it to drink (which Augustine expressly excludes), and it is questionable whether the 'confession' should be taken seriously at all. Augustine was not the vigorous and robust individual the passage would suggest. He was slight of build and short of stature, and always ailing. He has frequently to absent himself from Hippo-much to the concern of the numerous grumblers in his congregation - on account of his health. We have heard him complain of serious lung disorder at Milan. Later he tells that he cannot endure the cold; and in another letter he complains of hemorrhoids. $\mathrm{He}$ must have been a man of intensely nervous and sympathetic temperament. Frequently he seems only to gather strength when he has begun his sermon or other task. With such a constitution, worn down still more by frequent fasts and incessant toil, Augustine is hardly likely 


\section{I6 ST. AUGUSTINE AND HIS AGE}

to have had serious trouble in controlling his appetite.

The Eastern custom of reading the Scripture or some religious work during meals was introduced by Augustine. But he hit upon a happy device for the control of unkind impulses on the days when conversation was allowed. He had a couplet painted or carved on the table, which reminded the diners continually that 'whoever loves to carp at the lives of the absent must know that this table is no place for him.' One's character was safe in Augustine's presence; unless, indeed, one had the misfortune to be a Manichee or a Donatist. The couplet was not a mere ornament, as such things are apt to become. Possidius tells how some brother bishops were dining with him on one occasion, and the conversation gradually wandered on to the forbidden ground. Augustine rose at once. 'Either let us remove those words from the table,' he said, 'or let me retire.' He was equally rigid in his relations with the more dangerous sex. He visited no women except widows and orphans who were in trouble. No woman, not even his sister or his nieces, ever lived under his roof; and it was with difficulty, and only in the presence 
of witnesses, that he ever saw a woman at all. One would like to have had his comments on Jerome's very different conduct, and Jerome's on his.

Augustine's ideal of community life brought him many a troubled hour. The truth is, it must be confessed, he was a most unpractical man, and a poor judge of persons. ${ }^{1}$ The good became better in his company-I have said that he gave ten earnest bishops to the African Church; but many found their way into his house and service who were not good, and he had a poor eye for hypocrisy. Before many years we find him much concerned about one of his monks and one of his priests, who accuse each other of revolting conduct. Augustine sent them to the shrine of St. Felix of

1 Mr. Kingsley has introduced him in Hypatia as endowed with a sober and practical judgment which made large amends, in that author's esteem, for his doctrinal excesses. Like every other 'historical' character in that brilliant work of fiction, Kingsley's Augustine is quite untrue to life. Still one cannot help having a feeling of indulgence for the novelist. His 'purpose ' demanded that he should offer the reader an alternative to the Neo-Platonist moralists he was decrying, and even his subtle imagination failed to find the material for one in the Church of Alexandria. No doubt, we should not look for history in romances; but in this case a German critic, Stephanus Wolf, has recommended the characters for historical faithfulness. It is not likely that Augustine ever saw Synesius or the Pentapolis. The line of division of east and west-a very real one-lay between them. 


\section{ST. AUGUSTINE AND HIS AGE}

Nola, in Italy, to ask a miraculous decision in the case. About the same time he has to depose another priest in his paracia for flagrant conduct. Other scandals will be found at a later stage. For many years his theory of a community of goods seemed to work admirably; and as Possidius says he kept no keys, and only demanded an account of the domestic economy once a year, we can well understand it. He was awakened to suspicion by the public scandal of one of his priests leaving a sum of money at his death. Then he held an inquiry, and found that most of his clerics paid little practical attention to their vow, or, at least, solemn promise, of poverty. $\mathrm{He}$ thereupon rescinded his rule of ordaining no cleric who would not agree to live in common at the episcopal residence; but the culprits seem to have promised amendment, and he renewed his unwise regulation.

He seems also to have had not a little trouble in striking the mean between the lofty feeling of detachment from the things of earth and the pressure of its practical claims. There are indications that his congregation and his community frequently grumbled at his lack of zeal in securing gifts and legacies for the Church. On the other 


\section{THE DAILY TASK}

hand, the poor bishop actually incurred the reproach of avarice on more than one occasion. Thus in 405, when he consulted a venerable colleague as to the propriety of his decision in a certain case, he found that the bishop 'was greatly horrified' (ep. 83) at the character of his proposal. A certain Honoratus, who had been a monk in the monastery at Thagaste, and afterwards a priest at Thiave, had died intestate at the latter place. The people of Thiave claimed his property for their church, but Augustine and Alypius (now bishop of Thagaste) decided to keep half of it for the Thagaste monastery. Augustine hastily awarded the whole property to Thiave when the ill-sounding murmurs reached him. In another case, early in his episcopate, he seems to have quarrelled with his congregation about some property left to the Church by a deceased navicularius. This was an official of the Roman world who had to ship the corn to Rome, and was responsible for its safety unless he could prove (for which purpose three or four of the crew were always put to the torture) that the accident to his ship was unavoidable. If the Church accepted the property, it would accept the hereditary office and responsibility, which Augustine very rightly declined to 


\section{ST. AUGUSTINE AND HIS AGE}

do. On another occasion a rich citizen of Hippo, living at Carthage, sent him the deeds of some property, which was to pass to the Church at his death. After a few years he sent his son with a humble request that the tablets should be given to him, as the father now wished to leave the property to his children. The letter which Augustine wrote the man, after returning the deeds, has, unhappily, not been preserved. But Possidius tells us that he put a due degree of warmth into his 'increpation,' and refused the offered consolation of a gift of money. It must be understood, however, that Augustine had generally a humane feeling in these matters, and advised parents to provide for their children before they thought of the Church.

From all this the reader will have gathered that the Christian community, as well as the pagan, looked to the wealthy for the support of its pastors. It is by no means an agreeable impression that one receives of Augustine's congregation on reading his letters and sermons. It is not only small, but it is exceedingly poor in spiritual quality. The sermons are constantly recurring to the coarsest vices, and are full of complaints of empty benches, especially when the pagan festivals 
coincide with the Christian. The letters complain time after time of grumbling and mutiny ${ }^{1}$ in the congregation. They rarely seem to appreciate that they have in their obscure service the greatest genius in the Church. To an extent, we must trace this to Augustine's weakness as a preacher. $\mathrm{He}$ had a few great successes-the extinction of the love-feasts, of faction-fights, etc.-but we can well understand that his ordinary sermons were not likely to overcome the attraction of the pagan carnivals. They are generally plain, solid, moral discourses, greatly preoccupied with impurity, drunkenness, and divination; or else commentaries on Scripture which are more ingenious than attractive. They seem to have lasted any time between ten minutes and a couple of hours. Manicheans and pagans would come to hear him occasionally, but it is clear that he is generally addressing a small group of ignorant people. Petrarch has described as ' a magnificent and notable work' one of his largest productions (the Commentary on the Psalms), which consists of a couple of hundred sermons, delivered, for the most part, to the people of Hippo. There must

1 Cf. Epistle 124, where he speaks of his people as being greatly excited and ' most dangerously scandalised at my absence.' 


\section{ST. AUGUSTINE AND HIS AGE}

have been few who appreciated his ' magnificence.' One of his biographers affirms that the women did not like his sermons. That would be a unique experience in the history of pulpit eloquence, but the passage which is quoted seems to refer to one sermon only. It is probable, however, that Augustine imposed a strain sometimes on the fidelity of the gentler sex. He had a strong tinge of the Oriental habit of depreciating woman, as we shall see in noticing some of his later works. We can form some idea of the mental level of his audience when we find him telling a friend that he has to address them in bad Latin, saying 'ossum meum' for 'os meum,' and so on ; they in turn sing their hymns and psalms in the same dialect (' floriet' for ' efflorebit,' etc.). Still, only a few of them speak Punic. When he quotes a Punic proverb at times, he has to translate it into Latin. That is what we should expect in a busy Mediterranean seaport in Roman Africa. ${ }^{1} \mathrm{He}$ seems to have prepared his sermons carefully in his earlier years. Later on they were taken down

1 Yet such is the equipment for their work of some of the writers on Augustine, that we have one of them (Mr. C. H. Collette) speaking thus, with the grave and authoritative tone of a Mommsen: 'I have not been able to satisfactorily account for the fact that the numerous sermons attributed to Augustine are in Latin.' 
by the notarii, as he sat talking from his chair in the apse of the basilica. Possidius says many people used to bring notaries with them to church. He preached very frequently throughout life, sometimes for quite a number of days in succession.

In the other functions of the Church, except baptism and the preparation of the 'competents,' Augustine would have the assistance of his clergy. Mass was already a daily liturgical function in the African churches, and there was a service of psalms and hymns which he calls the vespertina. One of the Catholic hagiographers has the audacity to represent Augustine as a busy father confessor after the modern type. He must, at all events, have received a certain number of the confidences which then went by the name of confessions. From time to time, also, his Church offered visitors the curious spectacle of a public penitent, when one of his congregation had been notoriously guilty of some graver crime, such as murder, sacrilege, or adultery; though we cannot think, after reading his sermons, that the law was applied strictly on the last point.

Apart, however, from the greater simplicity of the services and the noisiness and carelessness of 


\section{ST. AUGUSTINE AND HIS AGE}

the worshippers, the Church of the early centuries had many unfamiliar scenes to offer. Notably, there were the privilege of 'sanctuary,' and the right of freeing slaves. The lex asyli was greatly abused in the early Christian Church, as we learn from a decree of 396 , which forbids monks and clerics to favour the escape of criminals and defend them with armed force in their churches against the officials. The securing of the privilege was one of the many narrow-minded measures of the bishops of the fourth century, which helped to corrupt the Church they thought to serve. At Hippo there was probably no violent or strained use of the privilege, yet Augustine's conduct was marked by his usual unpractical optimism and want of discrimination. On one occasion, when a parishioner named Fascius had fled to the church, and the angry officials chafed at the door, he paid the man's debt himself on condition that the money was to be raised by public collection if the man failed to pay it by a certain day. On the appointed day the man was, of course, missing, and the collection had to be made to cover the loss to the church funds. There can be no doubt that even a moderate use of the privilege fostered idleness and swindling. 
Another privilege that helped to increase the congregations of the Christian churches, and was equally questionable in its social and moral effect, was the manumission of slaves. Constantine had granted the privilege after his conversion; but it was not extended to Africa until the year 40I, when a Council of Carthage begged the extension from the emperor. After that date the manumission of a slave must have been frequently witnessed at Hippo. Augustine had no sentimental objection to slavery. The light in which he regards that institution in his De Opere Monachorum is little superior to the opinions expressed by Prætextatus and his fellow-pagans in the Saturnalia. He fully recognises the right of the conqueror to enslave the conquered. However, he always urged his people to free slaves who expressed a desire to enter a monastery-even the rapidly-growing abuses of the monastic life did not discourage him from this-and he probably always assisted with pleasure at a manumission. The slave was brought to the church by his master, and the tablets of sale were broken there, with some ceremony and edifying talk.

But perhaps the function that occupied most of his time was the one he discharged in the episcopal 
court. St. Paul had exhorted the faithful not to drag each other before secular judges, but to let their elders adjudicate between them. The advice had been largely followed, and the Christian emperors were persuaded to give a formal recognition to the judicial powers of the bishops. The work now increased so much that Arcadius had to regulate it in 398 and 400 . He left the episcopal court a purely voluntary tribunal, but gave its decisions a legal effect for such as chose to have recourse to it. The civil courts of the provinces were far from being in an ideal condition, so that non-Christians as well as Christians flocked to the house of every distinguished bishop. The practice had the effect of causing a good deal of friction between civil and ecclesiastical powers (witness the amiable relation of St. Cyril and the prefect Orestes at Alexandria), but it is obvious that it tended to purify the judicial system of the empire and to secure justice for the poor. At Hippo there was, naturally, a vast quantity of this work to be done. Augustine generally spent the morning in his court, 'fasting,' says Possidius, 'sometimes until the dinner hour [our eleven o'clock], and sometimes for the whole day.'

$\mathrm{He}$ soon won a reputation throughout Africa as 
an arbitrator and mediator, and petitions came to him from all quarters. Debtors, especially, seem to have claimed his services, and his vague and unpractical way of looking at commercial matters always inclined him to sympathy. Many of his letters are written to plead the cause of some hardpressed individual in a remote part of Africa. Even pagans who had brought the wrath of the Christian emperor upon their towns by some attack on the local basilica or clergy in a festive moment appealed with confidence to Augustine. He always improves the occasion by a few shots at their gods and goddesses, but their appeal to his humanity seems always to have been successful. At another time we find him gently expostulating with two of his colleagues who are fighting for the primacy of the Numidian province; ${ }^{1}$ at another, he is blaming a colleague for excommunicating a family for the fault of an individual member. In another letter (247) there is, for our consolation, a flash of temper, when his effort at mediation seems to miscarry. $\mathrm{He}$ has been chiding a certain landowner for making his

1 It did not occur to him to settle matters by the device which has so happily solved a modern difficulty of the kind; by which one prelate takes the title of 'Primate of Ireland,' and the other 'Primate of all Ireland.' 
tenant-farmers pay their rent a second time (the agent having absconded with the first), and the man has refused to call on him during a visit to Hippo.

His letters reveal a most varied activity of a charitable kind. At one time he writes from Carthage to remind his clergy and congregation of the custom of clothing the poor of Hippo. $\mathrm{He}$ had an annual collection of cast-off garments and distribution amongst the poorer members of the community; but in the excitement of the year 410 the clergy had omitted the work. There was also a hospital built near his church; and there were nunneries which relieved the monotony of life (as is the custom in those institutions) by quarrel and intrigue, requiring Augustine's intervention. Even the arrangement of marriages claimed his attention sometimes, much as he resented the circumstance. It was not uncommon in those days for a dying parent to make the Church the guardian of his children. We have a series of letters in which Augustine negotiates with a pagan who has asked a ward of the Church for marriage with his son. At another time we find him concerned about the ransom of some of his congregation who have 


\section{THE DAILY TASK}

been captured, apparently by the African tribesmen. He is unable to collect sufficient money to pay their ransom, and so, following the example of St. Ambrose, he melts down the sacred vessels of his church, and sells the metal.

Yet amidst all these varied and distracting episcopal duties, Augustine found time for controversial work and letter-writing, which form of themselves an extraordinary monument to his industry. His occupations at Hippo seem to be of no account whatever. His eye is constantly sweeping over the African provinces in search of a grievance to remedy, or a prominent heretic to defy. Synods and councils innumerable drag him from one end of Africa to the other. Aurelius of Carthage, the nominal chief of the African Church, detains him at Carthage until the murmurs of his congregation become intolerable. Yet month after month, and year after year, fresh works issue in his name, some of them astounding in their volume. From every part of Africa, from Spain, Italy, and Gaul, questions are sent to him and obscure heresies denounced. One day a man picks up a small volume in the streets of Carthage, treating of a heresy he is unacquainted with. At once he forwards it to the great Augustine of 


\section{ST. AUGUSTINE AND HIS AGE}

Hippo, and presently he has a work dealing with the matter. The heretics have to circulate their books with caution after a time, lest they fall under the eye of the terrible bishop. But we may deal a little later with his works.

In the meantime, Possidius tells us, he sends out challenges right and left to public debate, though few are eager to meet the 'Punic wrangler,' as his rivals soon describe him. We have seen how effectually he crushed the Manichean bishop of Hippo. The Donatist bishop, Proculeianus, was also urgently invited to hold a public debate with him, but he managed to evade it. A few years later he had a debate with another Manichean, Felix, in his own church. The acta are not interesting reading. Felix is an incompetent and shifty debater, and Augustine has already made some progress in pious intolerance. At the close of the first day's debate Augustine prudently handed the man over to a Christian, who was to see that he did not retire prematurely from the conflict. After a second day of the unequal struggle Felix wearily renounced his heresy. Augustine does not improve in temper with the advance of his experience in debating. One of his Donatist adversaries, 
Cresconius, complains of his 'unbearable arrogance'; and a courtly and cultured Arian bishop, who invited him to cross swords in later years, was forced to tell him that he 'talked like a man who had the support of the imperial laws.' As a rule, this seeming arrogance was due to a purely religious intolerance of heresy and zeal for conversions ; the irritation of defeat is usually on the side of his adversary. Sometimes his opponent succeeds in having the debate without reporters -though the presence of the notarii is always Augustine's first condition-and then (as did the Arian Count Pascentius ${ }^{1}$ after a debate at Carthage) spreads abroad a very safe assertion that he has defeated the great dialectician.

Finally, we have to consider the wonderful collection of letters which Augustine has left us. It is a commonplace that a man is most easily recognised in his letters, and this could be said of no writer with greater truth than of Augustine. He reveals himself with singular completeness in his correspondence. The earliest of his letters date from his stay at Cassiciacum after his con-

1 In this case he was afterwards not entirely unthankful for the exclusion of the notarii. He says afterwards in a letter to Pascentius: 'What reply I made to that I do not care to remember, and I trust you do not.' 
version. From that time we can follow the development of his character and his opinions almost by an exclusive study of his letters. His industry in answering correspondents is bewildering when we remember his endless occupations. That a Symmachus can find time to construct brief, polished epistles-after the fashion of the hour-is intelligible enough, but the promptness and generosity with which Augustine meets every petty demand on his time are almost unparalleled. Take, for instance, his i 8 th letter. A young man $^{1}$ was setting out from Africa for Athens, and, desiring to make a favourable impression in that city of learning, he coolly sends Augustine a long list of questions, which he begs him to answer. Augustine takes the request quite seriously, though he prefers to give the youth much unasked spiritual advice with a little secular knowledge. He returns his list with a few answers on the margin, and writes him a long

1 M. Poujoulat, the chief biographer of Augustine in France, protests there is no reason for thinking the questioner was ' a young man,' but Augustine calls him a 'boni ingenii juvenem' in this very letter. I notice the point because it is Poujoulat who denounces Gibbon for his 'profound ignorance' and for daring to write about Augustine after having read only the Confessions and the City of God. It is, however, true that at least the letters should be read by one who would know Augustine. 
letter. Imagine Dr. Ingram replying at length to an Eton boy (not of the fold) who wishes to look smart at Cambridge, and sends him a list of questions about the astronomical opinions of Sir Robert Ball and the philosophy of Professor Ward.

The huge collection of Augustine's letters contains scores of equally interesting documents. A widower has sent to ask him for a panegyric of his late wife; he gets one, together with a lengthy dissertation on his own vices. An enterprising young woman writes to tell him that the scandals in the Church greatly disturb her, and she is consoled at great length. A married woman writes to tell him that her husband has 'broken out.' She had taken a vow of chastity, and had succeeded in persuading him to do likewise; but when she went on to add a vow of poverty, and give all their valuables to a couple of vagabond monks who passed along, the husband's less heroic virtue broke down. Augustine writes her a patient ethical analysis of the situation, the only defect of which is that he insists she shall keep her vow of continence. Another Christian sends a formidable list of difficulties. Is it lawful to kill an aggressor in self-defence? to eat food 


\section{ST. AUGUSTINE AND HIS AGE}

that has been sacrificed to idols in order to avoid death by starvation? Augustine does not like to admit either; but he is more reasonable in answering the questions whether Publicola may deal with a pagan butcher, or drink from a well with a guardian deity, and so forth. In another letter he deals with the very practical question of female finery, paint, false hair, etc. He dislikes it almost as much as Jerome does, but he is lenient in the case of maidens who are 'on the market;' for married women he will not hear of paint or powder. A Carthaginian lady, who has sent him a shirt which was made for a brother who has died, is thanked at great length. A community of monks is rent into factions by a quarrel about his teaching, and he has to pacify them. A community of nuns have quarrelled about their chaplain, and he has to intervene. His letters frequently run to twenty or thirty chapters.

His correspondents are of all classes of the community. The meanest tradesman or most obscure of maidens is noticed as promptly as the highest officials of the province. We shall see that quite a number of the latter were in frequent and friendly correspondence with Augustine. Colleagues in the African Church and bishops 
beyond the seas are in constant communication with him. He has a long and voluminous correspondence with Paulinus of Nola. Paulinus was a senator of a rich and noble family who had been ordained Christian priest in 393 , and had retired to Nola with his wife since 394 . He and Therasia send long and intensely spiritual letters (the bearer always bringing a few loaves of the famous Campanian bread) to Augustine, and nowhere does he yield more freely to his mystic and spiritual tendency than in his replies to these.

But I will close with a brief account of his interesting correspondence with St. Jerome. Jerome had quarrelled with his fellow-monks in the desert of Chalcis when he came to Rome in 382 ; he had a violent quarrel with the whole of the Roman clergy, and was forced to leave the city when Pope Damasus died in 385 . He departed for the East once more, taking a number of his spiritual daughters with him, and settled down to a grim and gloomy monastic life at Bethlehem. Augustine's lack of discernment soon brought upon him a bewildering experience of Jerome's peculiar type of saintliness.

In 394 or 395 Augustine wrote a letter to the famous monk, expressing admiration of his 


\section{ST. AUGUSTINE AND HIS AGE}

works, and inviting Jerome's attention to his own writings. The letter was a very proper and courteous one, on the whole, but in the course of it he ventured to criticise Jerome's interpretation of Gal. ii. I I-I4. It is the passage where Paul modestly describes how he 'withstood Peter to the face.' The very human-looking episode was troubling some of the new converts, and so Jerome had explained that it was all a pious make-believe for tactical purposes. Augustine saw the danger of admitting that principle in the interpretation of Scripture, and pointed it out to Jerome. This first letter did not reach Jerome, the bearer not going to Palestine. In 397 Augustine wrote again; but once more his bearer, a priest named Paulus, made a considerable circuit before reaching the Holy Land. The result was that the Roman clergy got hold of the letter, and made merry over Jerome's defeat in his favourite field of study, long before it arrived at Bethlehem. Jerome was, therefore, sorely angered against Augustine. The letter itself was rather less discreet than the preceding, being characteristically confident in argument, and pleasantly inviting Jerome to 'sing his palinodia.' But the chief offence was the imaginary one of having published 
his criticism broadcast without sending it to Jerome himself.

Augustine, marvelling at Jerome's failure to reply, sent a third, a sweet little letter, to Jerome, and the eruption began. The reply came in 402 . It was moderately bilious: ' Far be it from me,' said Jerome, "to dare touch the works of thy holiness. I am quite content to care for my own writings without criticising those of others. For the rest, thy prudence is well aware that opinions are free, and that it is a childish boastfulness, only befitting youths, to seek renown by attacking illustrious men. . . Be content, therefore, to love one who loves thee, and do not thou, a youth, provoke an old man in the field of Scriptural study.' In the following year a deacon was going out to the East, and Augustine forwarded another letter to Jerome. It is not clear whether he had received Jerome's letter by this time-the Benedictines think he had not, at all events; he again wrote courteously, but once more admitted infelicitous passages which show how little he understood his brother saint. He had heard that Jerome was determined to retranslate the Old Testament from the Hebrew, and, having a rather superstitious regard for the current Septuagint 


\section{$23^{8}$ ST. AUGUSTINE AND HIS AGE}

version, he begged him to be content with amending that. It is in this letter, also, that he tells Jerome the story of the preacher and the gourd.

Jerome replied at once. He very plainly intimates at the outset that he is by no means convinced of the sincerity of Augustine's explanation. The people about him are urging, he says, that 'there has been some duplicity.' If it is true that Augustine has not written against him, 'how is it that the Italians have got what thou hast not written? or why dost thou ask me to reply to what thou now sayest thou hast never written ?' 'As I told thee before,' he says again, 'either send the letter to me signed with thy own hand, or cease to worry an old man in the retirement of his cell. But if thou art determined to exercise or to parade thy learning, seek out a youthful opponent, one who is eloquent and noble.' He greatly resents Augustine's invitation to 'sing his palinodia.' Probably errors would be found in his own writings if they were scrutinised; 'but,' he continues contemptuously, 'I do not say this because I have already found anything to censure in thy works, for I have never looked at them.' Finally, he dismisses his 'friend' with the salutation: 'Farewell, dearest friend, my son 
according to age, my parent in dignity; and let me beg of thee that in future when thou writest to me, thou wilt take care that the letter reach me first.'

If ever a saint has an indisputable right to indignation-and I should be the last to question it-Augustine certainly had that privilege after receiving Jerome's letter. Jerome had been inordinately slow to understand the miscarriage of letters (in an age when this was a daily occurrence), and had been almost brutal in questioning Augustine's good faith. But Augustine's reply is singularly noble and magnanimous. 'Tantene animis calestibus ire?' he must have asked himself in astonishment when he read the letter; but he does not allow even his astonishment to find expression. ' I beg of thee,' he says, 'that, if it be possible, we seek a subject to discuss whereby our hearts may be nourished without the bitterness of discord. And if I cannot say what may seem to me to need emendation in thy writings, and thou in mine, without the suspicion of ill-feeling or the injury of friendship, let us refrain from such things and spare life and health. I know that I am far from that perfection, of which it is written: "If any one 


\section{ST. AUGUSTINE AND HIS AGE}

offend not in word, he is a perfect man." Yet I think I may find it easy to ask forgiveness of thee if I have done thee hurt; and this thou shouldst make known to me, so that when I have heard thee thou mayst have gained thy brother.'

A soft answer does not turn away wrath on the moment. Jerome wrote one more bitter letter. 'I pass over the salutation with which thou soothest my feelings,' he began; 'I say nothing of the compliments with which thou seekest to console me in my correction, and come at once to the point.' $\mathrm{He}$ then discusses the question which Augustine has raised with regard to his interpretation of Paul. 'Thou hast found a new argument,' says Jerome ; ' being a bishop of such repute throughout the world, ${ }^{1}$ thou oughtest to promulgate thy opinion and win the assent of thy fellow-bishops. I, in my poor monastery, with my fellow-monks, that is to say, my fellowsinners, dare not lay down the law in these matters. . . Surely thou must have discovered something better, since thou hast rejected the authority of the older writers.' $\mathrm{He}$ makes

1 This phrase, isolated from its context, is frequently quoted by. the hagiographer in proof of Augustine's great reputation. 
unkind reference to Augustine's acquaintance with the Greek fathers and to his weakness for writing lengthy epistles. 'The lengthy discourse is apt to be lacking in intelligence,' he growls; and 'with all respect, it seems to me thou dost not understand the question thou hast put.' Finally, he concludes: 'Let me beg of thee, at the close of my letter, not to press an old man and retired veteran into the fight once more. Do thou, who art a youth and at the summit of pontifical dignity, be content to teach the people; enrich Rome with a new harvest from Africa. All I ask is to live in peace in some corner of my monastery with a pupil and a reader.' A few months later he wrote again, and seemed to be quite pacified. 'Enough of these quarrels,' he said; 'let us be friends again, and for the future exchange only letters of affection, not of controversy. . . . Let us, if thou wilt, play without hurting each other in the field of Scriptural study.' Augustine immediately replied with a letter which is admirable, save for a rather foolish protest against the term 'play.' He goes into the Scriptural question at length, and concludes with a fine chapter on the ethics of Christian controversy. ' In many things,' he candidly avows, 


\section{ST. AUGUSTINE AND HIS AGE}

'Augustine is Jerome's inferior;' and he pleads for 'freedom in charity.' The few letters that passed between them afterwards were always friendly. Augustine constantly presses for Jerome's opinion, and Jerome is always finding difficulties to excuse himself. But he is complimentary in all, and in one letter (418) writes as an enthusiastic admirer of Augustine. Later in life Augustine declared that Jerome abandoned his first position on the meaning of Paul's words. $\mathrm{He}$ himself retained a salutary consciousness of Jerome's rhetorical capacity. In his Retractations he tells how, when he failed to elicit Jerome's opinion on the origin of the soul, he reserved his own work on that subject until after Jerome's death. ${ }^{1}$

1 Jerome adopted the view of the origin of the soul which is now universally held by Catholic philosophers-that each individual soul is created by God when the body is ready to receive it. Augustine felt that this injured the theory of the transmission of original sin, and he therefore favoured the theory of propagation of souls, like bodies, from parents to children. 


\section{CHAPTER XI}

AUGUSTINE AND THE DONATIST SCHISM

$\mathrm{W}_{\mathrm{E}}$ have already had frequent occasion to speak of the Donatists. The African Church was split into halves throughout most of the fourth century by that most famous schism of the early Church. At the beginning of Augustine's career the great majority of the Christians of Africa belonged to the schismatical, or Donatist, faction. Even at the close of the century it is questionable if the Donatists were not still in the majority. But as soon as Augustine became a power in the Church, the success of the Donatists began to wane. $\mathrm{He}$ devoted himself with intense ardour to the extinction of the schism, and the first twenty years of his episcopate are largely absorbed in the controversy. In order to understand this aspect of his work, we must glance at the history of the schism. M. de Pressensé and other philosophic historians assure us that it was a natural expression of the 


\section{ST AUGUSTINE AND HIS AGE}

growing democratic protest against the advance of hierarchic pretensions. The fatal objection to the theory is that the Donatists had a hierarchy no less ambitious and authoritative than that of the Catholics; and there was at that time no question whatever in Africa of anything like allegiance to Rome. The real origin of the Donatist schism is far more prosaic, and offers little ground for large political theories. ${ }^{1}$

After the close of the last persecution of the Christian Church, its adherents began to emerge into the light of day and repair the breaches in their organisation. The stress of the persecution had lain heavily on north-west Africa, and it was a small and obscure body that formed its Church in the early years of the fourth century. So much is familiar history. The unfamiliar circumstance, which the chronicles of the fourth century abundantly establish, is that this obscure and struggling body was undermined by corruption. One naturally assumes that the Christian clergy who survived the last of the great trials of the Church must have been exceptionally chastened. No assumption could be further from the truth.

1 The classical authority on the Donatist schism is Optatus, bishop of Mileve, who wrote his famous history about the year 374 . 
It is in an ecclesiastical soil of exceptional grossness that the Donatist schism took root.

The actual outbreak of the schism dates from the year 3II. In that year the bishops of the Proconsular (or Carthaginian) province met at Carthage for the ordination of a bishop to that important see. Mensurius, the preceding bishop, had been summoned to court to answer for a contumacious subordinate. Having a presentiment that he would not return alive, he buried the gold and silver vessels of his church and intrusted the secret to two of his senior clergy, Botrus and Celestius. He had, apparently, a shrewd, if unflattering, appreciation of his clergy, and so he gave a list of the buried treasures into the charge of a pious old dame in his congregation. Mensurius did not return, and clergy and laity met for the purpose of electing a successor. Botrus and Celestius had been so much impressed with the wealth of their church that they exerted themselves to secure the election of one or the other to the see. However, a certain Cæcilian, who had been a popular archdeacon under the late bishop, secured the majority of votes, and was ordained bishop of Carthage by the assembled bishops. When, moreover, the old dame came 


\section{ST. AUGUSTINE AND HIS AGE}

forward with the secret list of the treasures, and Botrus and Celestius were compelled to hand over the full wealth of the Church to their more favoured colleague, they were reduced to an extreme stage of disaffection.

'Ambition and avarice' were thus two of the three great roots of the schism, says Optatus; the third was 'the anger of a humbled woman.' Cæcilian had had the misfortune to quarrel with an influential lady of the congregation during his archidiaconate. Lucilla, a wealthy matron of Carthage, had a habit of kissing the lips of an alleged martyr, whose body was preserved in the church, before presenting herself to receive the sacrament. There was, it appears, a great lack of discrimination in the matter of reverencing people as martyrs in that violent age, and Cæcilian had endeavoured to check the general laxity. He had forbidden the Christians to flock to the jails with stores of food and drink for the sustenance of all kinds of criminals under the pretence that they were martyrs of the Christian Church. He now scolded Lucilla publicly for 'preferring a dead man's lips' (Optatus has grave doubts about the martyrdom) to the sacred chalice, and the angry woman deeply resented his action. When 
Cæcilian was elected bishop, Lucilla joined forces with the disappointed elders, and they determined to elect a rival bishop. That was the origin of . the schism. All the subsequent pretexts and allegations are an after-thought; and all talk of a democratic reaction is quite out of place.

But to explain how the conspirators succeeded in causing a schism, we must glance back once more into earlier years. In the year 305 a small group of ten or a dozen bishops met at Cirta for the ordination of a bishop of that town. The persecution had just ended, and the senex, or primate of the Numidian province, Secundus, bishop of Tigisis, proposed to begin by an inquiry into the conduct during the persecution of the assembled bishops. One by one he accused his colleagues of having saved their lives during the persecution by delivering to the pagan authorities the Scriptures and other sacred possessions. ${ }^{1}$ One by one his colleagues admitted the crime, until he came to a half-savage prelate of the name of Purpurius. 'You are accused of murdering your nephews,' said Secundus to him. 'Yes, I did kill

1 Those who had done this were called traditores, a term which will frequently recur. Mensurius of Carthage had saved his life by giving up dummy books and having a little diplomatic understanding with the local authorities. 


\section{ST. AUGUSTINE AND HIS AGE}

them,' answered the prelate, 'and I 'll kill anybody who attempts to upset me.' $\mathrm{He}$ added that if Secundus tried to bully him as he had done the others, he would inform the meeting of the way in which the primate had saved his own life in the persecution. Secundus took to reflection at that, and finally decided to 'leave the whole matter to God.' They then proceeded to ordain the new bishop of Cirta. The clergy and the better part of the laity were opposed to the candidate (Silvanus), who was presented for the see, saying that he was a notorious traditor; but the lower orders, who favoured Silvanus, had shut them up somewhere during the election, and thus secured a happy unanimity for their candidate. The Numidian bishops were induced, by the gift of a respectable sum, to overlook the irregularity of the election, and they ordained Silvanus; the new bishop's first act being to confer the priesthood on the man who had furnished the bribe for Secundus and his colleagues. ${ }^{1}$

1 All this was subsequently proved before the civic authorities by a deacon of Cirta who was deposed by Silvanus. The interesting acta are to be read in Migne's volume of Optatus's history. To complete the picture of the group, who play an important part in our schism, let me add that Purpurius and another bishop were also convicted of stealing silver cups and a quantity of vinegar from the pagan temple. 
It was to these men that the thoughts of the conspirators turned. They were invited to Carthage, and were received at the house of Lucilla. Various reasons were then discovered for questioning the validity of Cæcilian's ordination. Secundus maintained that a primate (the bishop of Carthage being primate of the Proconsular province) should be ordained by a primate. But the chief allegation was that the bishop who had laid hands on Cæcilian, Felix of Aptunga, was a traditor. This was a serious point to raise, since it was then easy to spread the idea that an ordination might be invalid if performed by an unworth minister. Cæcilian entered into communicat: ": with the Numidian bishops, offering to cume before them for a discussion of the situation, and asking that at least they would ordain him themselves, if they held his ordination to be invalid, since he had been unanimously elected by the people and clergy. Purpurius alone saw an advantage in this offer ; 'let him be invited here,' he said in barbarous Latin, 'as if we were going to ordain him, and we'll smash his head in for his trouble.' The other bishops had a rudimentary moral feeling, it appears, and they preferred to ignore Cæcilian; moreover, the people, 
hearing of the threat, refused to let Cæcilian go to their council. Pocketing a heavy bribe from Lucilla, the seventy bishops proceeded to set up a second bishop at Carthage, selecting a certain Majorinus, a reader of the Church, and one who shared the affection of Lucilla with the dead 'martyr.' They then gave Majorinus the usual letters of communication with all the churches of the Roman world, and the Donatist schism was launched. ${ }^{1}$

Such is the undisputed story of the origin of the Donatist schism. In view of the misleading theory of M. de Pressensé and other Christian Presbyterians, I have thought it necessary to describe the sordid episode at some length. Nor can it be said that we may trace a democratic reaction in the remarkable growth of the schism. In the course of time, as will be seen, the Donatist ranks were swelled by thousands of fugitive slaves and labourers; and we find many democratic pleasantries, such as forcing the wealthy Catholic to pull the chariot in which his slave was seated, or to take the place of the miller's ass. But this is a purely accidental circumstance. There was

1 It took the name of Majorin's successor, Donatus, a much abler and more energetic individual. 
precisely the same hierarchic claim on the Donatist side as on the Catholic. There was no question whatever of Rome's pretensions, or of reaction against them. It is true that after a few years Constantine had the quarrel adjudicated upon at Rome, but the Roman bishop then acted only as an important and impartial neighbour who was called in to arbitrate; and that not by the Africans, but by the emperor. It will be seen that throughout the whole century of the struggle neither Catholics nor Donatists recognised the mild pretension of the bishop of Rome to a kind of vague supremacy. The truth is, that even the notion of a federation of Churches was only dimly conceived at the beginning of the schism. It was elaborated by the Catholics, or Cæcilianists, in the course of the struggle when they found the 'churches beyond the seas' to favour the case of Cæcilian; just as, on the other hand, the Donatists only elaborated as the schism advanced their central position of the invalidity of sacraments (whether baptism or ordination), conferred by sinners. The dogma of a central authority to which submission was required would have been a point of the first importance in the arguments of the Cæcilianists. They do not even whisper it. It 
was 'a concern of the Africans,' as both sides agreed at the great Council of 4II, and 'the churches beyond the seas' were to stand aside and communicate with the winner, after they had fought it out.

I will touch very briefly the development of the schism down to the time of Augustine. Rome had a traditional horror of the reiteration of sacraments, just as Carthage had a traditional laxity in that regard. ${ }^{1}$ Rome, therefore, could not hesitate to communicate with Cæcilian, and that meant the support of the newly converted emperor for the Cæcilianists. The Donatists, seeing that the imperial gifts were going exclusively to their rivals, appealed to the emperor for a decision. The case was, of course, decided against them at Rome, Arles, and Carthage, after a series of inquiries; and finally, by Constantine himself in 316. At first Constantine persecuted the schismatics, though he is said to have told the Africans eventually to settle the matter themselves. His successor took little more notice of them,

1 St. Cyprian having, a few years before, defended the practice resolutely in defiance of the bishop of Rome. I avoid the use of the word 'pope,' because every important bishop was called a pope at that time; Jerome gives that title to Augustine, and Augustine to Ambrose. 
and under Julian their churches we restored to them and their bishops recalled. Valentinian and Gratian passed a number of violent decrees, confiscating their churches, etc.; but none of these were enforced very rigorously until 398 , the date when we find Augustine facing the schism. In 395 Theodosius, the able and zealous ruler of the East, passed a severe law against all heretics who exercised priestly functions. $\mathrm{He}$ died in the same year, and Gildo, an African prince, usurped authority over the whole of that diocese. Gildo was very friendly with an active Donatist bishop, Optatus of Thamugade, and during his brief authority the Donatists spread over the provinces with the wildest licence. They had by this time associated with their cause a vast and remarkable army who went by the name of the Circumcellions. ${ }^{1}$ It seems hardly just to compare this army with the Covenanters, or any other historical body, as is done sometimes. In addition to the genuine religious fanatics who flourished their 'Israelites' (heavy clubs) over the heads of the Cæcilianists, there were undoubtedly thousands whose only attraction lay in pillage and violence. Fugitive

1 Because, says Augustine, they used to wander from hut to hut (circum cellas) of the peasantry, begging or exacting food and shelter. 


\section{ST. AUGUSTINE AND HIS AGE}

slaves and vagabond monks flocked to the standard. Augustine tells many a story of Catholic delinquents evading the discipline of the Church by joining the Donatists, and of women who thus escaped from marital control; in one letter (No. 35) he tells of a deacon, suspended for improper behaviour at a certain nunnery, immediately passing over to the Circumcellions with two of the nuns. At a word from one of their bishops these wild hordes would spread into a district, and fill it with revolting outrages. They would pour vinegar and salt-water down the throats of the Catholic clergy, put lime in their eyes, and sometimes cudgel them to death. They would seize their churches, wash and scrape the walls and floors, burn the wooden altars, sell the sacred vessels in the open market-to be bought generally by sordida mulieres, says Optatus-and cast the consecrated elements to the dogs. They would force the laity to receive Donatist baptism, and see that they were faithful to their new profession. They would harness wealthy Cæcilianists to their own chariots, turn respectable patresfamilias into millers' asses, put rush tunics on priests and daub them with mud, burn and plunder houses, destroy debtors' tablets, and commit a thousand outrages. 
During the short usurpation of Gildo this pandemonium was at its height. At the beginning of 39.8, however, Gildo was defeated by the imperial forces, and the Church would have been more than human if it had not retaliated. Before the end of the year Honorius reaffirmed the decree of Theodosius, and awarded the penalty of death to all who violated the churches or assaulted the clergy of the Orthodox party. But we have now arrived at the date of Augustine's struggle with the schism, and must review its further progress in the light of his actions.

Augustine was well acquainted with 'the fury of their drunken Circumcellions' from the beginning of his episcopate. When he came to Hippo he found that the Donatist baker would not bake for the Cæcilianists. He found his people often violently forced into the Donatist communion, and his clergy assaulted. He himself only escaped an ambush they set for him on one occasion by providentially losing his way. Yet it need hardly be said that his attitude was at first one of gentleness and forbearance. We have to follow his development step by step until he became what Barbeyrac has called 'the patriarch of Christian persecutors.' 


\section{ST. AUGUSTINE AND HIS AGE}

Augustine's first Donatist document is a letter to a bishop of the sect named Maximinus, written in the year 392. It is a courteous, if not friendly letter, greeting Maximinus as 'most beloved and honourable brother.' In the following year he wrote his popular ballad against the sect and his work Contra Epistolam Donati. In the same year a provincial synod, which met at Hippo, dealt gently and temperately with the question, and decided to allow Donatist priests to retain their functions after conversion if they had not rebaptized, ${ }^{1}$ and if they brought their congregations with them. In 397 a Council of Carthage discussed the question of admitting to the service of the altar converts who had received Donatist baptism in their infancy. Legates were sent to ask the opinion of the bishops of Rome and Milan (the two being put on a quite equal footing); and when these prelates opposed the idea, the Africans quietly disregarded their opinions (though they sent further legates to convince them), and adopted the practice. The fact that some of their churches had 'not even an unlettered deacon' to serve

1 The Donatist practice of repeating the baptism and orders given by the Cæcilianists was now one of the chief rocks of offence. They held that the Catholic 'orders' were not valid, coming originally from a contaminated source-the traditor, Felix of Aptunga. 
them moderated their dogmatic feeling. In the same year Augustine had another public debate. $\mathrm{He}$ had endeavoured to arrange one with the Donatist bishop of Hippo, but without success; though he had urged the civil magistrate to put pressure on his rival, and had spoken with some warmth of the excesses of the Donatists. However, in 397 he was passing through a small town on his way to Cirta, and he heard that the Donatist bishop was at home. He at once went to the house and engaged the bishop, a quiet and tolerant old man of little ability, in a debate. Augustine stipulated for the presence of notaries as usual, but they seem to have been Donatists, and they refused to work. His own clerics then commenced to take down the debate, but a great crowd of idlers pressed in, and made so much noise with their comments and applause, that the debate has unfortunately lost the reward of immortality. Augustine afterwards wrote his version of the proceedings to his rival's congregation, and complained that Fortunius had falsified copies of some of the works they referred to.

In 398 Gildo was defeated, as I said, and the golden age of Donatism came to an end. By this time the Cæcilianists were reduced to a pitiful 


\section{ST. AUGUSTINE AND HIS AGE}

condition in the country. But this was the year of the turn of the tide. Honorius at once renewed the law of Theodosius, which imposed a heavy fine on every heretic exercising sacerdotal functions, and curbed the violence of the Circumcellions. Augustine still looked with disfavour on the interference of the civil authorities in the controversy. It was about this time that he wrote his two books Contra Partem Donati (which we no longer have), in which he declared that he 'liked not to see the schismatics violently forced into communion by the exercise of secular authority.' We have a private letter in which he shows that he is even averse to parental pressure being put on children of mature years ; he desires no converts who do not come to him with perfect spontaneity. But his attitude rapidly changes in the following years. We can trace the growth of his opinion in his letters until we find in $40 \mathrm{I}$ open indications of a change. One of the ablest of the Donatists was an ex-advocate, Petilian, now bishop of Cirta. He was the Augustine of the Donatist party, the successor of their great Donatus of Carthage. Augustine secured a copy of his writing against the Cæcilianists, and began his work Against Petilian's Letter. In the 
second book of this work he not only defends the use of force by the example of Christ in the temple, but he sets an example of intemperance and arrogance of speech which the Donatists quickly follow. Petilian's temper was not improved by remarks about his 'diabolical pride' and 'most inept loquacity,' and he repaid in the same coinage. In the third book Augustine has entirely lost the idea of moderation. $\mathrm{He}$ is sadly domineering and abusive: 'Let him go now,' he says at one stage, 'and denounce me as a dialectician with his puffing lungs and turgid throat,' and there is much talk about his 'stupid cursing' and 'blasphemous mouth.' In the end he modestly contrasts their respective writings as "the inflated and the solid, the bloated and the sound, the storm and the calm, divine utterance and human presumption.' In the meantime he had an adventure with another able Donatist bishop, Crispinus of Calama. His disciple Possidius, now Catholic bishop of that town, was attacked by the Donatists in a neighbouring village. They set fire to the house he took refuge in, thrashed the men of his party, and stole all their horses. Possidius, obviously acting on Augustine's advice, appealed to the law 


\section{ST. AUGUSTINE AND HIS AGE}

- not the civil law, which would punish his assailants, but the new law of Honorius against heretics, which he claimed to apply to Crispinus. The Donatist was convicted, and it was only the intercession of Augustine and Possidius that saved him from a heavy fine. But the important point is that Augustine has appealed to the law against heretics. There are other indications that his feelings are hardening. In all that he writes from the beginning of the fifth century he betrays a pitifully narrow and sectarian judgment of his fellows. Thus in his De Bono Conjugali (written in 401 ) he finds that " the dinners of the just are more meritorious than the fasts of the infidels, the marriage of the faithful more meritorious than the virginity of the heretic'; in fact, the heretic's fast is 'a service of demons,' the Donatist virginity ' no better than fornication.'

Of the many works he wrote against the Donatists at this period little need be said. They have no literary value, and little human interest of an agreeable kind. They repeat incessantly the familiar arguments on the familiar pointswhether Felix of Aptunga was a traditor, whether the sacraments given by an unworthy minister are invalid and so forth. Between 400 and 410 
he wrote his De Baptismo (seven books), Contra Epistolam Parmeniani (three books), De Unico Baptismo (an answer to a work of Petilian's which is 'inflated only with sounding words,' but which he answers for the sake of 'slower minds '), and the four books Contra Cresconium. The lastnamed work (written in 409) is a temperate reply to a Donatist grammarian, who had taken up Augustine's reply to Petilian, and asked (evidently in reference to Augustine's abusive language) whether he thought of 'finishing by his intolerable arrogance' a controversy that had proceeded so many years. In his letters Augustine expresses his feeling about persecution with perfect candour. In 406 he writes to a venerable Donatist bishop (ep. 88) in defence of the recent severe law against the schismatics. They appealed first to the court, he says ; it is a case of the guilty taking Daniel's place in the lions' den. He still, however, lays great stress on the outrages of the Donatists (admitting to some extent that the Circumcellions generally get a quid pro quo from the Catholic laity) in extenuation of the law. A little later (ep. 89) he writes a candid and direct defence of the laws. Their coercion is 'a most merciful discipline,' the 'medicine of the Church'; 'mad- 


\section{ST. AUGUSTINE AND HIS AGE}

men' must be bound and 'lethargics' must be stirred up for the sake of their health-even the devil would be less bold, he thinks, if some coercion were imposed. $\mathrm{He}$ is clearly passing from his apologetic attitude to the view that religious coercion is an admirable institution. And two years afterwards, in a letter to the Rogatian bishop, Vincentius, he shows himself 'the complete persecutor.' Vincent seems to have written to chide him-notice the perversity of human judgment !-on his degeneration since their school-days at Carthage, when Augustine was a 'quiet and respectable youth.' Augustine replies (ep. 93) with a long and unwavering defence of coercion. 'The important point is not whether a man is compelled,' he says, 'but to what he is compelled.' The fruits of the imperial laws are their justification. He knows even Circumcellions who are now grateful that the pressure of the laws had led them to study the Cæcilian position more carefully. In a word, persecution has at length appeared to him in the light of a providential and highly philanthropic institution; it is a use of force which he can only compare to the coercion with which we prevent a feverpatient from flinging himself out of the window. 
$\mathrm{He}$ adds the tu quoque argument and the usual appeal to the outrages of the Donatists; but the dominant idea of the letter is an appreciation of religious coercion in and of itself.

The laws to which Augustine refers in these letters are those which Honorius was induced to pass in 405. Two years previously the Cæcilianist bishops, in council at Carthage, had sent a temperate and earnest challenge to the Donatists to meet them in a public conference. The Donatists scornfully rejected the invitation, and Augustine thereupon wrote a letter to the laymen of the sect, in which he pointed out the moral of the refusal of their clergy. This greatly incensed the Donatists, so that the only immediate result was a renewal of the activity of the Circumcellions. But with Augustine's gradual conversion to the policy of coercion a change of tactics was inevitable. He had hitherto been the chief obstacle to a change of policy, constantly appealing to his colleagues to rely exclusively on moral force in matters of religion. His moral force had not achieved the success he had anticipated. His works found able critics, and his challenges to debate were rarely accepted, and still more rarely effective. In the year 404, when the African 


\section{ST. AUGUSTINE AND HIS AGE}

bishops met at Carthage on the 26th of June, he gave his fatal sanction to the policy of recourse to the 'secular arm.' Two bishops were sent to ask Honorius to enforce the law of Theodosius and make it explicitly applicable to the Donatists ${ }^{1}$ they asked also that he would renew the law which made invalid all legacies to heretics-except in the event of conversion. Honorius replied in February of the following year with a severe law. $\mathrm{He}$ declared the Donatists to be heretics, confiscated the meetinghouses and goods of all who repeated baptism, excluded them from testamentary benefits, and imposed heavy fines on aggressive controversialists. It was now open to the Catholic bishop to drag his rival - as we have seen Possidius drag the bishop of Calama-before the civic tribunal, and have him not only heavily fined, but also branded with the odious appellation of heretic. Carthage was almost immediately purged of the schismatics. When the bishops met again in the month of August, they sent two of their number to thank the emperor for his welcome legislation,

1 The law was directed against 'heretics,' and the Donatists claimed that, on any view of the controversy, they could not be accused of more than schism. In dogma and ritual they agreed entirely with their rivals. 
and issued a letter to all the African judges, acquainting them with the tenor of the new law.

The next three years were marked by a dreary and repellent struggle with the angry schismatics. Homeless and proscribed, the Donatists had no weapon but their dreaded club, and they used it with vigour. The fifth century was not of a temper to meet violence with meekness, and Africa was soon devastated by a kind of civil war. ${ }^{1}$ On the 23 rd of August, 408, the virtual ruler of the Western Empire, Stilicho, came to an ignominious end. Schismatics and pagans at once asserted that the coercive laws passed during his regency died with him, and began to seize their churches and temples once more. Stilicho's successor, Olympus, was a Christian, and Augustine wrote, at the first rumour of his promotion, to secure his interest on behalf of the Church. In the meantime (in October) the African bishops : met again at Carthage, and sent two of their number to the emperor at Ravenna, asking him to reaffirm the

1 So great was the confusion, that a Donatist named Marculus, who was put to death by the Catholics, and whom Augustine credited with self-destruction-who should, therefore, on either hypothesis be now in Tartarus,-is actually honoured year after year, under the title of Macarius, in the Roman Martyrology. So it is stated in a note in the Migne edition of Augustine (vol.ix. col. 526). 


\section{ST. AUGUSTINE AND HIS AGE}

validity of the laws passed in the time of Stilicho. Augustine was not present, but he wrote a second letter (No. 97) to Olympus, and urged him to secure the enforcement of the law without waiting for the deputation from Carthage. When Augustine's letter arrived we do not know. He speaks of writing ' in the middle of winter,' but we need not take that too literally; on the other hand, he obviously believes his letter will arrive before the Carthaginian bishops. Probably both reached Ravenna about the end of November, or beginning of December; and with them came a crowd of maimed and half-blinded clerics, who had fled to court with lively proof of the outrages of the Donatists. In December the emperor sent the desired decree to Donatus, the proconsul of Africa, and the work of making converts by fiscal machinery recommenced. Augustine wrote to Donatus (ep. I00), urging him to apply the decree at once, but to spare the lives of the Donatists and avoid all appearance of vindictiveness.

Then there occurred a development of the situation which somewhat perplexes the ordinary ecclesiastical writer. In the summer of 409 the African bishops were once more thrown into grave 
anxiety by the appearance of a new decree from Ravenna, in which Honorius suddenly attains a commanding height of humanity and toleration. $\mathrm{He}$ directs that in future 'no one shall embrace the worship of the Christian religion except by his own free will,' and rescinds his oppressive decrees against the Donatists. The writer of the article on Donatism in the Dictionary of Christian Biography notes that political considerations influenced the decision, but claims that it was dictated ' partly by the kindliness of heart' of the emperor.' Once more the spirit of the Donatists revived in Africa, and the hateful struggle was renewed about the altars of the Prince of Peace. In June 410 the bishops met at Carthage, and sent four delegates to Ravenna to renew their complaints. The answer came swift and sharp. The 'kindliness' of Honorius has had a brief reign. In September he sends the following decree to Heraclian, now supreme in Africa: "The decree which the followers of heretical superstition had obtained to

1 The emperor who-so Zosimus says-when told in 410 that 'it was all up with Rome,' anxiously inquired whether they meant his favourite hen of that name, and was greatly relieved when he heard that it was only the city of Rome that had fallen. For a choice specimen of the literary art of tempering justice with mercy, which is so admirably cultivated by the ecclesiastical writer, I would recommend the above article (and a few others) in the said Dictionary. 


\section{ST. AUGUSTINE AND HIS AGE}

protect their rites is entirely rescinded, and we direct that they suffer the penalty of proscription and death if they again venture to meet in public in their criminal audacity.' A few weeks afterwards a new decree was issued, ordering a public conference to be held at Carthage within six months, in which the Catholic and Donatist bishops should defend their respective positions before a civil judge.

I will deal more fully in the next chapter with the political events which are vaguely reflected in this rapid change of policy. For the moment, before describing the great conference at Carthage, I will only say that we have no need whatever to make a microscopic research into the character of Honorius. Since the death of Stilicho in 408, the court at Ravenna had lived in hourly dread of Alaric and his Goths. In 409 Alaric set up a rival emperor at Rome, and the possession of Africa became of supreme importance to him and his puppet. The practised army of the Circumcellions would have been a formidable auxiliary to an invading force, and it was well known they would not hesitate to join the Arian Goths. Hence the momentary 'kindliness.' The small force sent by Attalus into Africa was cut up by 
Heraclian in $4 \mathrm{ro}$. Honorius was informed that the loyal count had detained all the corn-ships, and was prepared to resist invasion. Hence the decree of September. But it was important that this religious schism, which had now revealed its grave menace to political unity, should cease as promptly and with as little violence as possible. Honorius, therefore, adopted the idea of a conference, which both Donatists and Catholics had urged more than once. On the I 4 th of October (six weeks after the fall of Rome) a decree was issued in the name of 'the pious, prosperous, victorious, and triumphant emperors,' appointing the tribune Marcellinus to convoke and preside at such a conference at Carthage.

And towards the end of May 4II, Carthage began to stir with an unusual excitement. The Donatists had sent the summons of Marcellinus into every village of Africa, and the aged and infirm were implored to spend their last strength in an effort to reach the conference; some of them died on the way. A long procession of two hundred and seventy-nine bishops, with thousands of their supporters, marched proudly into Carthage towards the end of May. All the chroniclers are Catholics, and we are assured that the Cæcilianists 
gathered two hundred and eighty-six bishops without straining their resources. The question of numbers was admitted to be of importance on both sides, and it would be interesting to know the date of the ordination of many of these bishops. It was at least made clear at the conference that the Catholics had in places two or three bishops within the limits of one Donatist parœcia. A further interesting circumstance seems to be suggested by the records. On the day the conference opened the Donatists were jubilant at finding they were in the majority, only two hundred and sixty-six Catholic bishops having signed the response, but they were greatly distressed to see twenty new bishops appear on the Catholic side when the roll was called. It looks very much as if the twenty were kept in hiding so as to give the Donatists a false security. Augustine also tells that he and a few others were discussing the situation a few days before the conference, and they doubted if more than one or two of their colleagues would express a willingness to resign if the verdict were given to the Donatists. To his surprise, all expressed such a willingness when a meeting was held to discuss the point. Thus the Catholics were able to make 
the magnanimous offer of resigning their sees if the Donatists proved their point, and sharing their ministry with their rivals if they themselves secured the verdict. Probably the only impression this generous offer made on the Donatists was the opposite to what Augustine intended. Those who lived with Augustine would feel no less than we do to-day that he would have thought it a sacrilege seriously to entertain the idea of losing his case and resigning his charge. It is difficult to see where the Donatists found a source of hope. Marcellinus was a zealous Catholic, and was much influenced by Augustine; and of the imperial inclination there could be no doubt. It is true that Marcellinus offered to retire if the Donatists desired another judge; but the tone of their reply, declining his offer, shows that they had no hope of securing an impartial judge. The debate was a farce, and the verdict a foregone conclusion.

On the first of June the conference opened at the Gargilian baths in the centre of the city. The Catholics had proposed that only seven speakers and seven consultors for each party, with four bishops to control the notarii, should take part in the conference. This was rejected by the 


\section{ST. AUGUSTINE AND HIS AGE}

Donatists, who attended in full force, and insisted on the attendance of all their rivals when the list of two hundred and eighty-six names was produced. Marcellinus took the chair, and was supported by the chief civic officials. When he saw the great throng of Donatist bishops, some of them weak with age and infirmity, he bade them seat themselves. The fanatical group refused to sit under the same roof as the 'traditores,' and Marcellinus and his officials politely relinquished their own seats. The president then read the conditions of the conference, and gave an assurance that the losers would suffer no violence for their zeal.

It would be of little interest to follow the course of the conference in detail. The official notaries were supplemented by four representing each party, and controlled by four bishops, so that we have a verbatim report of the proceedings, each speech being signed by the speaker. The first day was wasted in a quarrel about names and numbers, each side being now eager to prove how many bishops it had left at home. The second day was equally unprofitable. On the third day the tactics of the Donatists were cleverly met by Augustine and Marcellinus, and a long debate ensued. 
Petilian, the ex-lawyer, was the leader of the schismatics, and the 'conference' was little more than a warm encounter between him and Augustine. He first claimed that the period assigned in the emperor's decree had elapsed before the date of the conference, but Marcellinus rejected his difficulty. Then he claimed that, the Catholics having demanded the conference, the Donatists, as defendants, had a legal right to discuss the character of the plaintiffs. This was met by the production of a petition for a conference which the Donatists had presented in 406. However, Petilian was eager to discredit his great rival by reviving the old calumny of the philtre. After a nervous duel with Augustine-Marcellinus interfering in such a way that the distinguished prelate said, rather profanely: 'You take good care to defend them, by God !'- -he hissed out the question that burned on his lips: 'Who ordained you?' Another bishop added, amidst great uproar (little Alypius meanwhile demanding that the noise be put on the records), the Pauline depreciation of mere learning: "Though ye have ten thousand pedagogues, yet not many fathers.' Augustine shirked the question at first; but as it was repeated from all sides, he at length boldly 


\section{ST. AUGUSTINE AND HIS AGE}

stated that it was Megalius, and challenged them to discuss it. However, Marcellinus ruled the personal discussion out of order, and at last dragged the bishops to the question at issue. The Catholics tried to introduce the fact of their communion with the 'churches beyond the sea' (again laying no particular stress on the judgment of the bishop of Rome), but the Donatists at once protested, and the point was abandoned without difficulty. 'It was not a question of the whole world, but an African question,' said the Donatists ; 'the churches beyond the seas must wait and communicate with the victors.' Then the formal issue was discussed in the light of Scripture and history. The conference had begun in the early morning, and it was growing dusk when Marcellinus closed the discussion and cleared the room for the writing of the verdict. The Donatists had quickly abandoned the complimentary way in which they addressed him on the first day, and they were probably under no illusion when they were recalled to hear his sentence. The Catholics had proved their case to his satisfaction; the Donatists were to hand over their churches to the Catholics, and they were forbidden to hold further meetings. 
In the following year Honorius renewed his law against the Donatists, and in 4I4 (the death of Marcellinus reviving their hopes) he passed a fierce and brutal law, doubling the fines imposed on them, excluding them from testamentary advantages and from courts of law, branding them with 'perpetual infamy,' and banishing their obstinate clergy. The schism now entered upon its last and most bloody stage. The outlaws became fiercely indifferent to life. They flung themselves down precipices - it was 'a daily game' of theirs, pleasantly says Augustine (ep. I 85). They assailed armed groups of pagans and Catholics, and fought them to the death. They met travellers on the country roads, and threatened to kill them if they did not inflict martyrdom on their strange accosters. One of Augustine's priests was murdered by them. When these suicides were pointed out to Augustine, he coldly replied (ep. 204) that they did not move him; it was better, he said, that these few whom God had predestined to hell should perish than that all should be damned for want of coercion. Yet even he shuddered sometimes at sight of the spectre he had raised. We often find him pleading with the officials to refrain from 


\section{ST. AUGUSTINE AND HIS AGE}

violent retaliation, and especially from capital punishment. $^{1}$

The Donatists struggled for many years under the heel of the law. In 418 we find Augustine attempting to draw Emeritus, the former Donatist bishop of Cæsarea, into a debate in what had once been his own church. The embittered old man would not deign to speak. In the same year we hear of a meeting of some thirty Donatist bishops, under the resolute Petilian, to discover new ways of evading the laws. Two years afterwards Augustine writes to remonstrate with a Donatist bishop who has shut himself in his church with his flock, and threatened to set fire to it, when the officials come to apply the law.

1 To this extent Gibbon is wrong when he says that the persecution of the Donatists had Augustine's 'warmest approbation.' It had his approval only up to a certain point, and it was years before he overcame his feeling of humanity so far as to give this qualified approval. Yet, if Augustine had persisted in his opposition, it is not likely the persecuting laws would have been given to Africa, and so one cannot say with Poujoulat that Gibbon is 'grossly unjust ' to Augustine. Gibbon is also wrong (though not so 'profoundly ignorant' as Poujoulat would have him) when he says that, as a result of the great conference of $4 \mathrm{II}$, three hundred Donatist bishops and thousands of their inferior clergy were stripped of their offices and banished. We do not know how many (though we know that very many) of their bishops accepted the offer of the Catholics; and the proportion of clergy to bishops was not so great as Gibbon supposes-besides that their 'sees' were often very small matters. 


\section{THE DONATIST SCHISM}

The Vandals found the sect still struggling when they invaded Africa, and laid the proud structure of its rivals in ruins. There was a brief and limited revival at the end of the sixth century, but the remarkable sect only perished finally in the universal devastation of the Mohammedan invasion. ${ }^{1}$

I I dare not pursue the subject, or I would point out the gross fallacy that lies in the historic comparison of the position of the Church of England with that of the Donatists. But a discerning and impartial reader will probably perceive from the foregoing sketch that if there be a parallel at all, it lies between the Roman Church in England and the Donatist in Africa. It is the Romanists who reject the validity of their rival's sacraments and 'raise altar against altar.' The question of union with 'the churches beyond the seas' was a minor point with the Africans; nor is the Church of England by any means so isolated as was that of the Donatists. Finally, Christianity was then a loose federation of churches, with only a broad agreement in dogma and ritual, and without a shadow of a 'supreme head.' 


\section{ST. AUGUSTINE AND HIS AGE}

\section{CHAPTER XII}

THE DYING OF PAGANISM

I HAVE already observed that Augustine paid far less attention to the old national religion than to the heresies which sprang up within the Church. Only one work, the City of God, out of his innumerable productions was directed against it ; and this was occasioned rather by the turn of political events than by theological controversy. The few letters in which he further deals with paganism were elicited by correspondents, and the allusions in his sermons belong rather to moral than to dogmatic theology. Wherever he does confront it intellectually he pours a bitter and unsparing scorn upon it, but he usually ignores it altogether. It is true that some of the most cultured of his correspondents profess allegiance to it. With these he is usually content to advance the claims of Christianity ; and indeed they generally make 
it sufficiently clear that they are monotheists, with an historic and politic attachment to a NeoPlatonic conception of the Olympian system. Nevertheless, Augustine's career coincides with the downfall of the old religion, and it is interesting to study his attitude towards it in the successive phases of its disappearance.

We left the old Roman religion, a few chapters back, severely stricken by the laws of Gratian and the influence of St. Ambrose. When Augustine left Rome the national cult seemed to be breaking up rapidly. Prætextatus was dead, and Symmachus had withdrawn from the struggle. In the east Theodosius was putting decree after decree in the hands of the bishops and the monks, the ready executors of the imperial will. In $38 \mathrm{I}$, $383,3^{85}, 39 \mathrm{I}$, and 392 laws were passed against the priests and the adherents of the old religion, and armies of fanatical monks wandered over the provinces, leaving mounds of smoking ruins where the piety of their fathers had gathered the wealth and the art of the world. The great temple of Serapis at Alexandria fell before an ignorant mob, led by Bishop Theophilus, in 389 . In Syria the finest temples were laid in ruins. Arcadius continued the work of Theodosius; in 


\section{ST. AUGUSTINE AND HIS AGE}

$395,396,397$, and 399, he issued decrees for the destruction of the temples and the abolition of the pagan religion, only departing from the fervour of his predecessor by a shrewd direction that the material of the destroyed temples be used for the construction of roads and bridges. Throughout the eastern empire Christianity made rapid progress with the aid of such legislation. If in Rome, as Symmachus said, 'to desert the altars was a new kind of ambition,' it will readily be understood that the temptation was stronger in the vicinity of the Christian court at Alexandria. ${ }^{1}$ The pagan tradition was utterly broken. Every earthquake, pestilence, or other striking calamity, brought thousands into the new religion.

In the west the suppression of paganism was by no means so smooth a process. Valentinian II. had, as has been stated, continued the policy of Gratian, confiscating the revenues of the clergy and temples and withdrawing the last shred of imperial patronage from the old religion. The Christian leaders had pleasantly assured the pagans that they had no ground for complaint, since the

1 At the same time, there were pagans in high office even in the east, and a considerable licence was permitted the pagan writers of the eastern empire. 
new laws merely brought about a condition of equality between the two religions. But this ' equality' was soon discovered by Ambrose to be itself inconsistent with the dignity of Christianity. In 39I Valentinian was induced to pass another law, in which he commanded the pagan temples to be closed and all sacrifices to be discontinued. In the following year the young emperor was put to death by one of his generals, and a rhetorician, Eugenius, was clothed with the purple. This gave fresh hope and courage to the remnants of the pagan aristocracy. Nicomachus Flavianus, the third of the great pagans of the time, a pontiff and consul designate, at once threw himself with fervour into the new agitation, and espoused the cause of Eugenius. After two fruitless legations, Flavianus himself and Argobastes (the Gothic general who had set Eugenius on the throne) approached the new emperor, and obtained permission to restore the famous statue of Victory to the senate. The pagans saw an opportunity of escaping from the persecuting laws of Valentinian under the more accommodating Eugenius, and they threw in their lot with the usurper. There was a great revival of the old religion at Rome. The temples were re-opened. The victims were laid 


\section{ST. AUGUSTINE AND HIS AGE}

on the altars again, and the incense rose from every part of Rome. The stream that had begun to flow towards the Vatican was diverted once more. The new lease of life given to the old religion was of most uncertain duration; for, although Theodosius had at first exchanged presents with the puppet of Argobastes, it soon became known that he was preparing an expedition into Italy. Yet there was widespread apostasy from the Christian Church, and nearly the whole of the nobility welcomed the restoration of the genial Olympians. The Christian leaders were sorely perplexed; it was impossible to forecast the issue of the struggle with Theodosius. Ambrose wavered pitifully. He fled from Milan to avoid a meeting with Eugenius, yet wrote a most respectful and friendly letter to him, in which the usurpation is described as 'when thy clemency assumed the charge of the empire.' ${ }^{1}$

1 Compare the politic character of his panegyric on Valentinian, where he 'will not discuss the celerity of his death!' In an earlier chapter I have had to point out Gibbon's unjust severity against Ambrose; here it is necessary to say that he errs still more in the opposite direction. He says (iii. 402): 'The inflexible courage of Ambrose alone had resisted the claims of successful usurpation.' The above qualification of the 'usurpation ' would hardly require an inflexible courage. But as Gibbon adds that Ambrose 'declined his correspondence,' it would seem that he has strangely overlooked the 
The triumph of the pagan Romans and the perplexity of the Christian prelates were not of long duration. Theodosius quickly followed his presents to Italy with a large army, and defeated the usurper; the high-spirited Flavianus flinging himself on the emperor's troops when he saw that his cause was lost. The victor was singularly moderate towards those who had supported Eugenius, but he once more removed the pagan symbol from the senate and closed the temples. The decay of the old religion set in more rapidly than ever. Beugnot, it is true, questions this, but the inscriptions he gives after 394 are not convincing, as far as any large exercise of the old cult is concerned. Schultze and other recent writers admit the statement of Zosimus and Prudentius that Theodosius himself visited Rome, and harangued the senators on the change of religion. Within ten years we find Jerome writing (ep. 107) that " the Capitol is squalid and deserted; the temples of Rome are covered with dust and cobwebs; and the pagan gods keep their lonely vigils on the roofs with the bats and

letter to Eugenius (No. 57, Migne' edition). Beugnot, who is by no means prejudiced in favour of paganism in his well-known study of its fall, almost weeps over the perfidy of the bishop of Milan, 
284 ST. AUGUSTINE AND HIS AGE

the owls.' There was one later revival of the old religion at Rome before the final catastrophe, as we shall see, but it begins to sink in earnest from 394. The chief struggle takes place henceforth in the provinces, and we may transfer our attention to Africa once more.

When Theodosius died, his sons were mere children. Arcadius, who ruled the east, was in his eighteenth year, and Honorius in his eleventh. The western empire, therefore, was virtually ruled by the great Gothic general Stilicho, into whose charge Honorius had been given. Stilicho was not disposed to distract the empire with further religious struggles, and for several years the condition of the pagans was not very onerous. In 398 , however, he began a series of persecuting measures, and there is reason to think that Augustine had some share in bringing about the unhappy change of policy. During the few years between his ordination and 398 we find Augustine very little concerned about paganism. In his sermons he frequently scolds his congregation for taking part in the pagan festivals, but on the whole he seems to regard the old religion as quietly dying. But in 398 he was alarmed to notice a great animation amongst the pagans. Some zealot had 
composed a Greek verse, purporting to be the utterance of one of the sacred oracles, which predicted the downfall of Christianity in $39^{8}$. The pseudo-oracle represented Christ as an innocent enthusiast, but said that Peter had procured by magical arts a triumph of 365 years for the Galilean religion. Counting the period from the year 33 of the current era, the date of the breaking of the spell would fall in 398 . In that year, therefore, the pagans became unusually active and spirited, and the bishops of the African Church began their unhappy appeal to the secular arm. In the case of the pagans, at least, there was no room for an accusation of violence. However, in 398 we seem to find Augustine speaking, without a shade of hesitation, of recourse to repressive legislation. ${ }^{1} \quad$ Some time in that year we find him preaching (sermon 24) to a Carthaginian congregation on the pagan religion. The pagans had

1 The reader may remember that I have already represented Augustine as writing, about 398 (in his Contra Partem Donati), that he disliked the idea of secular coercion in the matter of the Donatists. Yet the sermon I am going to quote was quite certainly delivered before 399. It implies a large and public exercise of the pagan cult at Carthage and the absence of any repressive laws. This condition was not found after 399. The explanation seems to be that Augustine wavered for some years before his definitive declaration in favour of persecution. 


\section{ST. AUGUSTINE AND HIS AGE}

obtained permission from an indulgent official to gild the beard of their great Hercules, but their rejoicing was brought to a sad termination when it was found that a Christian had contrived to shave the impotent hero during the night. The Christians gather at their basilica in great joy, and Augustine laughs and jokes with them over the adventure. He tells them that at Rome the old worship has been abolished, and immediately the church rings with cries of 'Let us do here what has been done at Rome.' Augustine approves and encourages their zeal, but appeals for orderly procedure. Trust us, your pastors, he says : you will soon see whether we do our duty or not. The first law of Honorius (or Stilicho) against the old religion falls in the year 398 , and so we are compelled to conclude that Augustine and the Carthaginian bishops started the persecution of the old religion in Africa.

The law of 398 is not extant, but the fact of its having been given is inferred from the terms of the law of 399 , which probably repeats its enactments. The hope of the pagans was heavily and promptly cast down. As they peered anxiously over the sea for the first heralds of the revival 
at Rome, there came instead two high imperial officers with orders to close the temples and abolish the sacrifices for ever. The summit of Olympus flashed out no thunder whilst Gaudentius and Jovius went from street to street of Carthage and sealed the doors of the temples. The great temple of the Cælestis had been closed for some years, and huge thistles or cactus had sprung up in its splendid avenue. The pagans were consoled to believe that dragons lurked in this small forest, and guarded the deserted buildings; but one morning they awoke to a painful disillusion, for great golden letters announced on its front that 'Aurelius dedicated this temple to Christian worship,' and the Christian mob poured up the sacred enclosure with wild rejoicing. A chronicler of the time (pseudo-Prosper) speaks of temples being closed and sacrifices abolished throughout Africa in 399. Augustine pictures the Cæcilianists and the Donatists working in Christian unison at the work of destruction; dragging the marble statues into the streets and breaking them to fragments, smashing the flutes and other musical instruments of the pagan service, and even laying the temples themselves in ruins. So zealous was the execution of the law that a second 


\section{ST. AUGUSTINE AND HIS AGE}

rescript was forwarded to the African proconsul, directing that the temples should be stripped, but not destroyed, and that the sacred games and banquets were not to be prohibited. The African bishops were dissatisfied with the restriction, and in 400 we find them petitioning the Court for the suppression of the sacred games and banquets (under the pretext that Christians were morally compelled to attend them at times and hear their faith reviled) and the destruction of the remaining temples. A letter of Augustine's (No. 50), which Baronius assigns, with some probability, to this date, indicates both the confusion which these laws produced and Augustine's attitude towards them. At Suffecte the Christians had been inspired by the law to destroy a statue of Hercules, which was held in great veneration by their pagan neighbours. The very natural result was a sanguinary riot. How many of the poor pagans fell in the conflict the chroniclers do not deign to inform us; but the Roman Martyrology still reverently announces, year by year, that sixty Christians were 'martyred' on the occasion. The municipal officers were made responsible for the event, and they seem to have written to Augustine to plead the extenuating circumstance of the 
loss of their Hercules. Augustine replies with much cheap irony and contempt. He does not fail to point the trite, but dangerous, moral of the helplessness of their deity, and promises they shall have another when they have restored the sixty Christian souls. Other letters of his to pagan correspondents are of still more uncertain date, and therefore cannot be used to illustrate the development of his feelings. There is one (No. 232 ) to the leading officials of Madaura, the scene of his early studies. They seem to have recollected his obligation to their town, and written to ask a certain favour of him. In a spirit of friendly accommodation and liberality they greeted him as their 'father' and closed with the admirable salutation: "We wish, in God and $\mathrm{His}$ Christ, that thou mayst live happily for many years with thy clergy.' Augustine did as they asked him, but he read them a severe lesson on what he insisted on regarding as the mockery of their salutation. But there are one or two letters of uncertain date in which he argues temperately and courteously with cultured Neo-Platonists, who defend the old régime.

This condition of affairs lasted until 408, the bishops everywhere impelling the reluctant officials 
to put into execution the imperial edicts. In that year, as we hive seen, the brave and capable Stilicho, the last hope of the falling empire, was executed in prison at Ravenna. At the first rumour of his death new life was infused into the sullen remnants of the pagans and the Donatists. Stilicho was the author of the laws that had been issued in the name of the fatuous young emperor, and it was hoped that his disgrace implied a change of policy. It is true that his successor, Olympus, was a Christian, but that circumstance afforded no certain indication of his attitude, and the pagans raised their heads once more. But Augustine and the African bishops were by this time accomplished politicians. I have already related how they approached Olympus, and secured a continuance of the coercive policy. Stilicho was put to death in September; in December a fresh series of decrees reaffirmed and enlarged the existing laws. The annona templorum - the fund which maintained the sacred games and banquets-the last source of pagan revenue, was appropriated to the support of the army. Statues and altars were to be destroyed, and temples converted to municipal use. The bishops were empowered to see that the law was 
executed, and heavy fines were imposed on negligent magistrates. A second decree of the same month aimed at the more distinguished pagans, by excluding from the service of the emperor ' all enemies of the Catholic faith.' ${ }^{1}$ 'That the earlier laws were far from uniformly enforced is clear from an incident we learn from Augustine's letters. On the rst of June of the year 408 the pagans of Calama celebrated their feast of Flora with the usual licentious dances of the meretrices in the streets. They maliciously directed their procession before the door of the Catholic basilica, and a few zealous Christian stones precipitated a riot, in which a Christian was killed and Possidius (bishop of the place) had to fly for his life. He flew, of course, to Hippo, and Augustine directed him to Ravenna. In the meantime, an elderly official of the town, Nectarius, humbly begged Augustine's intercession for his heated fellow-

1 Gibbon says this decree was rigorously applied, whilst $M$. Beugnot, a high authority in this province, says it was at once repealed on the resignation of Gennerid. This pagan officer of high rank was assured by Honorius that the imperial eye was blind to the heterodoxy of those who were particularly useful to the State, but he nobly refused an exemption. Beugnot seems to mistranslate Zosimus when he says 'il ne perdit pas son grade.' The words of the historian

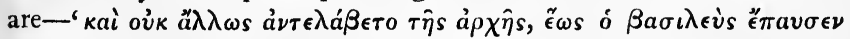




citizens. Augustine (epp. 9 I and 104) merely promised that the imperial 'medicine' should be administered with moderation; but as Possidius reached the court in troubled days, it is probable that the delinquents escaped altogether. However, the law of 408 was put in the hands of the bishops, and the licentious Floralia and Saturnalia quickly gave way to the more orthodox festivals of Pentecost and Christmas.

I have explained in the preceding chapter how the triumph of the hierarchy was rudely interrupted in the middle of the following year by the receipt of a reactionary decree which directed, to their grief and indignation, that ' in future no one was to be compelled against his will to accept the Christian religion.' Whilst rival theologians were puzzling their brains over the designs of Jupiter or Jehovah, the formidable Alaric and his army of Goths were making sad havoc of the imperial intentions. The reign of Olympus was speedily cut short by disgrace and death. The pagan Jovius succeeded to his office, and the Gothic army became masters of Rome. A Greek pagan, Attalus, who had recently received a diplomatic Arian baptism, was clothed with the purple by Alaric, and accepted by the senate; and the prefecture 
of the city was given to the pagan Lampadius. Once more the smoke of a thousand altars hovered over the eternal city, and the stately processions ascended the Capitol and the Palatine. Nearly the whole of Rome applauded the revival. $\mathbf{M}$. Beugnot sheds bitter tears over the 'infamy' and 'perjury' of the senators. Honorius meekly offered to share his empire with Attalus, but the Greek haughtily informed him that his generosity was superfluous, and clemently permitted him to retire to some obscure island with his precious poultry. The odds ran strongly in favour of Jupiter.

But the Africans had barely time to acquaint themselves fully with the latest decree of Providence when there came the dignified retractation of the privilege of following one's conscience in matters of religion, which I have given previously. Just as the wretched Honorius was about to yield, he received six cohorts from the east, and was enabled to fortify Ravenna against the terrible Goth. Moreover, Jupiter had forfeited his last chance by deceiving the augurs of Attalus. The possession of Africa was of vital importance to the parasitic capital; but, on the faith of the augurs' report, Attalus had sent only a small 


\section{ST. AUGUSTINE AND HIS AGE}

contingent to secure it. His soldiers were cut up by the loyal Count Heraclian. The corn ships were stopped, and famine and plague spread disaffection in Rome. Attalus was ignominiously stripped of his purple by the Goth, and the city itself was taken and pillaged by his soldiers in August 410. But Honorius had been restored to confidence by the loyalty of Heraclian, and he fiercely reaffirmed the decrees against Donatists and pagans.

The chief idea running through M. Beugnot's well-known study of the fall of paganism is that it was the barbarian invasion which really crushed the old religion. He does not seem to have imposed his theory to any large extent. The weight of the later inscriptions he gives, or of his interpretation of those inscriptions, is far from overwhelming; and we see only too plainly in the course of his own narrative the effect of thirtyfive years of repressive legislation and intense proselytic activity on a nerveless or soulless opposition. It is difficult to see that the Gothic invasion of Italy hastened the death of the old religion. In Gaul, Spain, and Africa, the pagans merely suffered in common with the Trinitarian Christians from the Arian Goths and Vandals; 
the rest of the barbarians, being pagans, were hardly likely to select fellow-pagans for exceptional punishment. Beugnot thinks that the disorganisation of the empire which followed the invasion tended to make an end of the tottering fabric. But modern historians think this disorganisation has been exaggerated; and, in any case, it would paralyse the effective anti-pagan machinery of Church and State much more severely than it would itself injure the old religion. The fact is that we find a momentary revival of the hopes of the pagans after the fall of Rome, and then an emphatic resumption of the coercive legislation. The administration which was set up at Rome after Alaric's withdrawal and death was largely pagan, and suffered a last flicker of the old religion. This was repressed as soon as the court resumed control, and its extinction practically terminates the public exercise of the pagan worship at Rome. Individual pagans of distinction are met with long afterwards, it is true. When Theodosius II. wrote : 'If there be any pagans left (though we do not think so),' he knew perfectly well that there were pagan officers in his own palace. But the old religion was virtually extinguished in the large towns by 4 I5, and the 


\section{ST. AUGUSTINE AND HIS AGE}

term 'pagan' (villager) - already long in usebecame a fairly correct appellation for its open worshippers.

In the provinces paganism prolonged its struggles far into the fifth century, and in some places survived until the seventh. In the African provinces we find the struggle proceeding until, in 428 , the Vandals put an end to all sectarian strife by an impartial devastation. In 4I 5 Honorius found it necessary to renew his threats and penalties, for the pagan sentiment was not a little obstinate in Africa in spite of the advances and concessions of the new religion. Pseudo-Prosper records, in his entertaining De Predictionibus, that on one occasion some of the condemned idols were found concealed in a cave in one of the Mauritanian towns, and the whole city, including the clergy, were convicted of 'perjury.' In fact, it would appear from an obscure passage of the decree of 4 I 5 that secret societies had been formed amongst the pagans, and the heads of these are threatened with capital punishment. It is also indicated that the pagan pontiffs had returned to the towns, and the emperor ordered them to retire to their native places. But the remaining temples were now closed, and all surviving statues destroyed. 


\section{THE DYING OF PAGANISM}

The old religion ceased to exist as an organisation in Africa. How the anti-Christian sentiment was fostered by the disasters of Rome and encountered by Augustine, I will relate in the next chapter. 


\section{CHAPTER XIII}

ECHOES OF THE FALL OF ROME

A RECENT French writer ingeniously concludes that Augustine's 'soul was rent' by the news of the fall of Rome, but he avoided the subject in the excessive pain it gave him. F. Ozanam, admitting, in a moment of rare candour, that Augustine was all but indifferent when the news arrived, thinks that 'either his genius was less bound by an antique patriotism or love had raised it to calmer heights.' The hagiographers are equally conflicting. The truth is that Augustine had scarcely a spark of human sympathy with the disasters of Rome. The sermon (De urbis excidio) which he preached on the receipt of the news expresses only an eagerness to draw spiritual profit from the event. In a later sermon (105), when he returns to his theme, he observes that his hearers are saying openly: 'Oh! why does he not cease to talk of Rome;' and he is obliged to 


\section{ECHOES OF THE FALL OF ROME 299}

disavow any intention of hurting their patriotic feelings. But such an attitude does not please the patriotic divines of our day, and it is concealed with an abundance of unwarranted phrases. Let us be more just to Augustine. The distinction of the two cities was already clear in his mind, and it forbade him to feel or express a sorrow for the misfortunes of the city of men. However, he soon found that a loud and angry murmur against Christianity surged through the empire in the train of the awful news.

If the transcendental aspect of the fall of Rome offered considerable difficulty to the rival theologians of the time, the merely secular problem, whether Christianity was responsible for the catastrophe, may be approached more hopefully. Boissier says that that, with certain reserves, the majority of modern historians agree with Gibbon that Christianity and Christian princes must bear the blame of the disaster, though Boissier himself resents the charge. Most readers will feel that that is not a just formulation of Gibbon's feeling, and modern historians draw up so lengthy and formidable a list of dissolving elements that they leave little room for the destructive action of Christianity. He would be a bold historian who would contend 


\section{ST. AUGUSTINE AND HIS AGE}

that Alaric would never have entered Rome if Diocletian had succeeded in extinguishing the Christian sect. Rome died of exhaustion, and the malady had set in long before the time of Diocletian. Christianity was not responsible for the wars that continued to drain the treasury and deplete the army throughout the fourth century; nor for the increasing decay of the curial or middle class, which mainly bore the financial burden, and was gradually ruined by the stupid fiscal system; nor for the depopulation of the environs of Rome and of the agricultural districts, that had fed the legions; nor for the concentration of the people in the towns and the increasing degradation and enervation of town life; nor for the introduction and training and evil management of the barbarians; nor for that displacement of the Huns in the far East which precipitated the barbarian avalanche. It may be urged that the emphatic otherworldliness of Christianity damped the ardour of patriotism and made light of the service of the empire. The patriotic feeling that had built up the empire had already been corrupted, or turned into a frothy jingoism, to use a modern term, by selfish dissipation. In any case, Christianity was not taken so seriously as that by any large 
ECHOES OF THE FALL OF ROME 30 I

proportion of the Romans. The number who shirked military and civic duties on religious grounds was very small in comparison with the number, of cowards. In fact, the Council of Arles had discountenanced the notion in $3 \mathrm{I} 4$, and we find Augustine repudiating it when he is pressed by anxious officials. Nor can we complain of the millions which a Proba or a Melania spent on the Church, when even richer Romans spent their wealth in selfish luxury.

As to the Christian emperors, the charge is clearly fallacious. It is difficult to see how it would have altered the fortunes of the empire if Honorius had been a pagan, or how much more Theodosius would have done for it, had he supported the old religion. It was one of the grim humours of fate-a fine crux for the providential historian, if he would face it frankly-that the senate had been relieved of its responsibility, the succession of a number of boy-emperors had left the direction of affairs and the employment of material at the mercy of a series of intrigues, and the action of two centuries of corroding forces had culminated, just in that half century when the greatest pressure was exerted on the walls of the western empire. Where vigour and wisdom and 
capability were wanting, religion could make little difference. If the fact that Gratian, Valentinian, and Honorius were Christians seems to have any significance, we have only to recall the sincerely Christian Theodosius, with whom, says Gibbon, 'the genius of Rome expired.' The one great political evil of the triumph of Christianity was the profound distraction of the empire by religious quarrels when every eye should have been bent on the movements of the tribesmen and the weakness of the empire. But it is more than doubtful if the absence of this distraction would have prolonged the life of the empire in its integrity for ten years.

No ; the murmur against Christianity, which at length impelled Augustine to turn his polemical faculty on the pagans, rested on less tangible considerations. We do, it is true, find a certain amount of the more rational criticism in cultured circles, though we have, as I said, singularly little knowledge of the feeling towards Christianity of the cultured pagans. One of the few open declarations in the Latin literature of the period is a bitterly contemptuous passage in the poet, Rutilius Numantinus, on the cowardly and unintelligible withdrawal from the world of the 
Christian monks. A more interesting glimpse is afforded by one or two of Augustine's letters of (most probably) the year 4I2. Amongst those who had taken refuge in Africa was Volusianus, a distinguished member of one of the noble families into which Christianity had penetrated, and afterwards prefect and proconsul. His mother had pressed Augustine to open a correspondence with him, and he did so, urging him to read the Christian Scriptures and submit his difficulties. Volusian replied with great courtesy and sincere respect. He said that he and a number of friends had been holding at Carthage one of the formal, rhetorical conversations which were then in vogue-somewhat in the style of the Saturnalia of Macrobius. A member of the group had introduced Christianity, and they had puzzled over the details of the birth and humanity of Christ. But the letter was covered by one from Count Marcellinus (who had presided at the great conference), in which he begged Augustine to send a careful reply, and said that, in addition to these rationalistic difficulties about the Incarnation, Volusianus and his pagan friends had been concerned about those features of Christ's teaching which Count Tolstoy now holds in solitary 


\section{ST. AUGUSTINE AND HIS AGE}

grandeur. They respectfully submitted that to turn the other cheek to the smiter was a somewhat questionable ideal to propagate in the empire. Augustine sent a long, careful, and ingenious reply, but it failed of its immediate object. Hagiographers generally declare that Volusianus became a Christian at Constantinople on his deathbed long afterwards, but even this consolation rests on a very dubious identification. All Augustine's concessions to human nature-as, that Christianity did not condemn war, etc.-could not cover the weakness of his position; indeed, he had to fall back in the end on the usual theory that ' faith opens the door to intelligence and infidelity closes it.' Volusianus seems to have preferred the rationalistic maxim with which Augustine himself always confronts alien revelations. Marcellinus also mentioned in his letter that the owner of most of the Hippo territory was present at the conversation, and spoke sarcastically of Augustine's failure to answer his own questions.

But the historic literary sequel to the fall of Rome was the writing of Augustine's famous City of God. For several years after the triumph of the Goths the murmur against Christianity rolled sullenly through the provinces. When the 
temples were closed and the sacrifices forbidden, the Christians enjoyed the facile triumph of asking: 'Where is the thunder of your Jove?' In 4 IO the answer sprang to the troubled lips of the pagans. The empire had been smitten for its infidelity. It was one of those popular cries that seem unanswerable to the multitude. They remembered the eloquent warning of Symmachus. Time after time Augustine returned to the point in his sermons, gradually elaborating the idea of his great work. Then brother prelates urged him to meet the attack. He himself had stimulated a young Spanish priest, who came to visit him, into writing a history of the world, which should show by the bare record of events-judiciously arranged or curtailed-the futility of the notion that disaster only entered the Roman world with Christianity. But Orosius had not the large ideas of the philosophic Augustine, and his history must have had little effect. By the year 4I3 Augustine had matured his central idea of the two cities, and he began the first of the twenty-two books of his most familiar work.

Of the work in its entirety one may safely say with Gibbon that ' it had the merit of a magnificent design, vigorously and not unskilfully 


\section{ST. AUGUSTINE AND HIS AGE}

executed.' 'The design to which Gibbon refers is the idea of the two cities, with which most readers are acquainted. Plato had conceived the world about us as a compound of two worlds, the light of the ideal world mingling with and breaking through the ever-changing panorama of the world of sense. In like manner Augustine conceives the drama of life to be a blending of two elements. The life of the individual and of the nation, as it appears to the natural mind, is part of a larger whole, revealed to us in all its grandeur by the Christian Scriptures. And Augustine's thesis is that only in this larger whole can we see the true proportion of historic events; only when we appreciate that the members of the city of men are also members of the city of God can we follow their fortunes correctly. But they who look for a philosophic unity in the work will be greatly disappointed. The first ten books are devoted to a rambling criticism of the pagans-five to historical and general criticism, and five to a criticism of their philosophers; the remaining twelve books bear the title of the City of God more appropriately, though they also were evidently not written on a preconceived plan. It could not be otherwise in Augustine's circum- 
stances. His days were crowded with work. It was only at rare intervals that he could find a few hours to devote to the book. He probably began it in 4I3, and wrote the first three books. In the year 416, when Orosius was with him, he had reached the eleventh book. He speaks of writing the fourteenth in 420 , and he seems to have completed the work in 426 or 427 . One knows how much unity to expect in such circumstances, and in view of the constant interruptions of Augustine's life. It is a wonderful presentment of Augustine's earlier erudition, loosely unified and curiously interpreted by his later theological opinions.

The first five books were intended directly to refute the current pagan murmurs, as I said, but they are hardly likely to have been very successful. The argument is strained and inconsistent, and the criticism small. He opens with an unhappy stress on the circumstance of Alaric sparing those who took refuge in the churches at Rome, which he declares to be unique. The Benedictines themselves refute his point in a footnote. Then, continuing his consolation of the wavering Christians, he gives the usual unanswerable reply to the question why God permitted the Christians to suffer; if they were bad Christians, they suffered 


\section{ST. AUGUSTINE AND HIS AGE}

for their sins; if they were good, the suffering was a purification and trial. But there was still less consolation in such phrases as: "No one was killed, who would not have had to die some day,' and 'What does it matter how a man's life ends so long as he is not compelled to die again?' $\mathrm{He}$ attacks the suicides of Lucretia and Cato in a petty spirit, and, when he recollects that saints have done something similar, takes refuge in particular inspiration. In the next book he urges that the Roman gods never commended probity of life ; and, when an esoteric doctrine of that kind is produced, he replies that the devil would not be the devil if he did not imitate the angel of light at times. When he proves the helplessness of the gods, in the third book, by narrating the disasters of Rome in pre-Christian ages, he has an easy task; but even this point collapses when he asks, in the following book, why God rewarded the Romans with so vast an empire (he remarks incidentally that extent of domain is no advantage); and when he answers that it is the 'natural ' (i.e. secular) reward for their 'natural' virtues, he forgets that he has previously handed over the early Romans to the inspiration and assistance of demons. In his anxiety to make all 
virtue theistic, he enters into a sorry criticism of the finest models of old Rome. Finally, he concludes the fifth book with a fine ideal portrait of a 'Christian emperor'; in sweet unconsciousness that its only use is to show what the emperors of the fourth century should have been and were not. This tissue of contradictions must have quite neutralised the force of his vast, yet imperfect, historical erudition, and his subtle and ingenious reasoning.

In the philosophic books (6-10) he vigorously attacks those who support the old religion on a ground-work of the monotheistic ideas of Varro or Plato. Whenever he deals with the details of the Roman mythology he is irresistible-and there is no one to resist him. He is less forcible in his criticism of Varro and of the Platonists, though he is still respectful to Plato. In the end he wisely entrenches himself on the inability of Varro or Plato to spread truth and virtue amongst the masses, and so introduces, in a very earnest and beautiful passage, the necessity of the Incarnation. The one defect here is his unconsciousness that the chief question is the historical onedid God become man? Probably few noticed that defect in his day. 
The second half of the work is constructive and theological. Six books $(1-16)$ are devoted to one of his innumerable efforts to get at the light which he was convinced was hidden in Genesis. ${ }^{1}$ The subtle speculations on creation are renewed from his Confessions, and the text of Genesis leads him to discourse on evil and sin, whilst he labours with painful ingenuity over the details of the now superannuated legends; in proof of the existence of giants in early times he quotes the finding of a huge tooth (possibly of a mammoth), and he thinks the angels may have taken the animals to the outlying islands after the flood. With even greater boldness he proves that Abraham did not tell a lie about Sara, and that the patriarchs were indifferent to sexual pleasure, and only propagated the race so largely out of a sense of social duty. In the concluding books he leads up gradually to an eloquent presentment of the Christian doctrine of the 'last things'-illustrating, by the way, the action of eternal fire from the life of the salamander, and sternly rebuking misericordes nostri for questioning

1 It is in the eleventh book that he anticipates Descartes' famous 'Cogito, ergo sum.' It has been proved that Descartes did not follow Augustine, but it has not yet been inquired whether Augustine borrowed the idea from Plotinus. 


\section{ECHOES OF THE FALL OF ROME 3II}

the eternity of hell. It seems to be a pretty general feeling amongst historical writers that the work cannot have had a great influence on its age, though it became the chief monument of Augustine's learning and power in after years. Again let me recall the circumstances under which it was produced; probably no other work of such a magnitude and ambition was ever written under such distracting circumstances. Augustine had little leisure for sustained reflection, and even less opportunity to complete his faulty erudition. To have produced a great work in such circumstances was a remarkable achievement.

To return to the period immediately after the fall of Rome. Africa was the natural refuge of the wealthy Romans who fled before the stream of barbarians, and some curious scenes were witnessed there in 4II and 4I2. One of these scenes occurred in Augustine's church at Hippo, and caused him considerable pain. Amongst the rich Christian families that fled from Rome was the very remarkable family of Melania, who came to Africa in 4I I, with her daughter-in-law Albina, and grand-daughter Melania the younger, with her husband Pinianus. Melania the elder, one of the most notable Christian ladies at Rome, and 


\section{ST. AUGUSTINE AND HIS AGE}

widow of a consul, had developed a quite fanatical fervour for inducing people to make vows of continence or embrace the monastic life. Albina seems to have been of a less nervous temper, and Melania concentrated her domestic zeal on her grand-daughter. The young Melania was a susceptible pupil, but she had married Pinianus at an early age in deference to her father's wish. The elder lady then made strenuous efforts to part the young couple, and they had consented to take a vow of continence after their second child was born. The young wife added many other ascetical practices, using a pious deception with regard to her more judicious spouse. Jerome's advice about the bath was taken to heart, and she used to bribe the slaves who accompanied her to the room to conceal the fact that she had not bathed; she is also said to have worn a hair shirt under her silken robes. When the fear of invasion began in 408, they sold their vast estates in Spain, Italy, and Gaul, liberating eight thousand slaves, it is said, and fled to Sicily, and afterwards to Carthage, with the proceeds and the income of their African domains. Simeon Metaphrastes, a hagiographer with a fine gift of rounding numbers and selecting striking facts, 
says that their palace at Rome was so costly that no one could buy it until the barbarians had reduced its value. However, scattering gold on 'the poor and religious clergy' as they travelled, they passed through Sicily and Carthage, and settled at Thagaste. There they continued their benefactions, founding a monastery of eighty monks and a convent of one hundred and thirty nuns, and spending vast sums in 'making converts.' They were naturally eager to see Augustine, but he explained in a letter to Melania that the severity of the winter prevented him from coming, besides that, he candidly added, his congregation were already 'most dangerously scandalised' at his frequent absence. Hence Pinianus and his wife came to see him at Hippo, and there occurred one of the curious scenes which enliven the church life of those informal days.

The people of Hippo were well acquainted with the wealth and generosity of Pinianus, and one day when he and Melania were at service in the basilica, they began to demand him for their priest. Pinianus seems to have had some previous experience of this kind, for he had in advance secured a promise on oath from 


\section{ST. AUGUSTINE AND HIS AGE}

Augustine that he should not be ordained against his will-a by no means uncommon contingency in those days. Augustine, therefore, curtly told the people of his promise, and threatened to leave them if they persisted. Some of their leaders then approached him in the apse, and pressed their request. He could only repeat his refusal, and a 'horrible turmoil' followed. The people loudly accused Alypius, who was with Augustine in the apse, of wanting all the wealth for his own church of Thagaste ; whilst Pinianus and Melania spoke bitterly of the sordid covetousness of Augustine's people. The bishop began to be apprehensive for the life of Alypius and, as he afterwards said, lest they should pull his church down. After a long and painful period of altercation and vituperation between priests and people, Pinianus was compelled to promise on oath that he would not leave Hippo or be ordained in any other church, and the people dispersed. It was a sad time for the poor bishop, as he indicates in a subsequent letter to Alypius. Albina openly associated Augustine with his congregation in the charge of avarice; 'the common people accused thee of this,' he says to Alypius, 'whilst we were accused by the lights of the Church.' $\mathrm{He}$ ' is 
ECHOES OF THE FALL OF ROME 315

not angry with Albina, nor does he think she should be rebuked,' but if anybody has given her a different version of the affair from the above he -or, rather, she, for he is clearly thinking of Melania-' either lies or is mistaken.' Alypius and Albina held that the oath extorted so violently from Pinianus did not bind, but Augustine claimed compliance with it. Eventually the difficulty was removed in an unexpected fashion. They were robbed of their remaining estates by the unscrupulous Heraclian, and the affection of the worthy Hipponenses rapidly cooled and restored his liberty to Pinianus. The elder Melania had already departed for the monasteries of the east, after making another fruitless attempt to separate the chaste spouses. When their wealth was gone, they also proceeded to Palestine, and rejoiced the aged zealot by breaking up their home and entering different monasteries.

The Heraclian I have just mentioned will be remembered as the loyal count of the African forces, who retained the country for Honorius against the forces of Attalus. In the confusion of 4IO and 4II his loyalty suffered a remarkable transformation, and ended at length in open rebellion. Heraclian was the leader of the 


\section{ST. AUGUSTINE AND HIS AGE}

Christian party after the disgrace of Olympus. Yet when the fugitive nobles fled to Carthage after the fall of Rome, they found this loyal and Christian prince awaiting them at the port 'like Orcus at the gate of hell,' to use Jerome's forceful phraseology. Alaric had been less cruel. Noble mothers fled with their daughters from the fierce Goths, only to find a more certain disaster at the hands of the Roman. Gibbon has observed or conjectured that ' the lack of youth or beauty or chastity' saved the honour of most of the ladies of Rome. Salvianus gives a very different idea of the Goths; but, in any case, large numbers of the Roman ladies had fled to Africa, and there wealth was their only preserver. Those who had not brought considerable treasure, with which to pay their footing on African soil, saw their daughters torn from their embraces and sold to the Syrian merchants who supplied the busy markets of the east.

Amongst those who suffered severely at the hands of Heraclian was a second trio of noble Christian ladies, Proba Faltonia and her daughterin-law Juliana, and grand-daughter Demetrias. I have said in a previous chapter that the palace of Proba, heiress of the Anicii and wife of the 
prefect Sextus Petronius Probus, was one of the chief Christian centres at Rome. Mr. Dill describes Probus as a rather lukewarm Christian; at all events, he and his three sons (all consuls) were not deterred by any lofty religious scruples from devoting their services to the falling empire. When Rome had fallen, the three ladies sailed for Carthage with such treasure as they could convey from the wreck of their vast fortunes. But they had only preserved the young and beautiful Demetrias from the rude embraces of Alaric's soldiers to find a crowd of Syrian merchants bidding for her on the quays of Carthage. Juliana is said to have parted with half her remaining fortune to the despicable Heraclian before she and her daughter were set at liberty. They then settled at Carthage, and we have a long letter which Augustine wrote them on prayer. Two years afterwards great excitement was caused throughout the empire, we are told, by the announcement that the young Demetrias, a famous beauty, and the last heiress of three celebrated families - the Probi, the Anicii, and the Olybriiwas about to make a vow of virginity. She was betrothed to a Roman noble, but the general apprehension that the end of the world was at 


\section{ST. AUGUSTINE AND HIS AGE}

hand seems to have reduced the harshness of the growing cult of virginity, and she, like so many others, yielded to the higher counsel apparently through the inspiration of Augustine. In 414 Augustine received from Juliana the usual apophoretum, or ' wedding-gift,' announcing that her daughter had taken the veil. Whilst worldlyminded Romans deplored this extinction of another of Rome's best families for a perverse and morbid ideal, Augustine and Jerome and the other Christian leaders showered the most enthusiastic panegyrics on the mother and daughter. Amongst others, Pelagius, who had already begun to disturb the western theologians with his sturdy defence of human nature, wrote an admiring epistle to the virgin, and did not neglect to point out the power and nobility of the human will which were exhibited in her heroic vows. The letter, or treatise, had considerable vogue at the time, and eventually fell under the eyes of Augustine, who at once wrote to assure the bewildered maiden that (despite his praise of her conduct) her virtuous action must be attributed entirely to the grace of God. But the episode is part of the celebrated conflict of Augustine and Pelagius, which we must reserve for a later chapter. Juliana 
seems to have returned to Rome with her daughter and the aged Proba, and the remnants of her once immeasurable fortune.

We must also regard as one of the immediate echoes of the fall of Rome the rebellion of the rapacious Heraclian. The count had been sent to Africa after the death of Stilicho, and had held it against the troops of Attalus. But the disasters of the empire and, probably, the sight of the hopeless incapacity of Honorius inspired him with an ambition for the purple. With his mad expedition to Italy and defeat by Count Marinus we have no concern, but there was a sequel which greatly agitated Augustine. When Marinus came to Africa to extinguish the last sparks of the rebellion, there was the usual zeal for the execution of prominent sympathisers. Amongst those who were denounced to Marinus was Augustine's friend, the tribune Marcellinus, who had presided at the conference with the Donatists. Orosius mentions in his history a suspicion that the Donatists had denounced Marcellinus and bribed Marinus to have him executed; Jerome is also of that opinion. It is impossible to say whether there is any truth in the suggestion, or whether Marcellinus was really implicated, but the 
circumstances of his execution are not free from suspicion. Augustine was at Carthage pleading the cause of his friend, and he obtained from Marinus a promise that no action would be taken until the bishops had communicated with the emperor on the matter. The promise was broken, and Marcellinus and his brother were executed in prison soon afterwards. Augustine's behaviour on the occasion is not so clear as one would wish; perhaps the kindest interpretation is that he left Carthage in pious indignation at the duplicity of the officials. The churches were, he says in a letter to Cæcilianus, filled with fugitive rebels who were protected for the time by the law of sanctuary, but sought Augustine's intercession for the settlement of their causes. Yet he left Carthage hurriedly and secretly, as soon as he heard of the execution of Marcellinus. He can only explain to Cæcilianus that, as he dare not face Marinus and 'rebuke him as he deserved,' he thought he had better leave the scene altogether. 


\section{CHAPTER XIV}

THE WORKS OF AUGUSTINE

THE preceding five chapters have presented so active and crowded a life that there seems little room left for literary labours. The long hours spent in preaching or catechising in his basilica, the yet longer hours devoted to his judicial functions, the frequent journeys to and long detention in Carthage, the constant overlooking of his parish (or diocese), the sermons and public debates abroad, and the painstaking and humble concern with every grievance that is put before him, make up a heavy burden for a frail and constantly ailing man. Yet we have up to the present hardly touched upon one of the most exacting and most remarkable of Augustine's performances. In the midst of all those distractions he found time for literary labours of exceptional magnitude. Eleven volumes of the Migne edition of the fathers are occupied with his extant works. Moreover, the 
variety of the subjects he deals with is amazing. In his commentaries he covers nearly the whole ground of the Scriptures; there is hardly a point of dogma or ethic which he leaves untouched in his theological works; he talks science with the Manicheans, philosophy with the Platonists, and history with the pagans. So extensive an activity has its disadvantages, of course. His scriptural work is feeble when compared with Jerome's learned and leisurely interpretations; just as the swift fluency of his style shrinks from comparison with Jerome's laborious production-the hermit of Bethlehem polishing and rewriting his letters most conscientiously at the very moment he is pouring contempt on literature. Nevertheless, his hurried writings are so instinct with high personal thinking, that Leibnitz has pronounced him to be 'endowed with a most vast talent,' Baur has said that 'no other theologian is so able or fertile,' and Sir W. Hamilton, on the philosophic side, has considered him ' one of the profoundest thinkers of antiquity.'

I have already dealt with Augustine's earlier works, as well as with his anti-Donatist and most of his anti-Manichean writings. In the next chapter I shall speak of his anti-Pelagian works. Besides these we have a large number of scrip- 
tural and theological works, which were written for the most part between 400 and 420. Many of these I shall not trouble to describe. Probably few, if any, living people have read even the greater part of Augustine's works. The interest of many of them is obsolete, and there is, naturally, a very large amount of repetition. The earlier works were too characteristic to be omitted. Where the later ones are also characteristic, or offer especial interest, I will point it out; but it would obviously require a not inconsiderable volume to contain the summary of all Augustine's works, and a rare patience in the reader to make it serviceable.

Commentaries on Scripture are clearly not works of which one may usefully give a summary, and two volumes of Augustine's writings fall in that class. The most notable of his biblical writings is his Commentary on the Psalms (Enarratio in Psalmos). This prodigious work, filling nearly two thousand columns of the Migne edition, was still read with admiring interest in the Middle Ages, and may even now serve to relieve the leaden hours in the life of some Carthusian monk. Petrarch calls it ' a magnificent work,' when he writes to thank Boccaccio- 


\section{ST. AUGUSTINE AND HIS AGE}

one wonders how much of it Boccaccio had readfor a copy of it ; and whoever cares to dip into it will find, with Petrarch, that it is ' not less remarkable for richness of sense than volume of letters. It is really a lengthy series of sermons, delivered in his basilica, or written for delivery, covering the whole book of Psalms. Unfortunately, this was the worst section of the Vulgate version of the Bible, reading at times as unadulterated nonsense, in which Augustine seeks wisdom, and succeeds to a painful extent. Jerome had translated the Psalms from the Hebrew, but the old version could not be dislodged from the memories and affections of the monks and people. Augustine seems to have begun his work about the year 4I4, and no doubt continued it for many years. Of other Old Testament works we have his two commentaries on the Heptateuch (written about 419), his Annotations to $70 b$ (c. 400), and his writings on Genesis. I have already described his earlier concern with the legends of Genesis, which had been quickened by Manichean controversy. For a long time he hesitated between the literal and spiritual interpretation of the book, but at length decided to defend a literal interpretation against the Manichees (who could not 
admit that God created matter, etc.). His first attempt, in 393, broke down: 'my noviceship failed under so formidable a burden.' $\mathrm{He}$ resumed the task about the year 400, and completed it in $4 \mathrm{I} 5$. The work is not only pathetic in its vigorous defence of speculations which modern divines calmly assign to Babylonian ignorance, but it is marred by many of Augustine's later ideas. The cosmological errors, the denial of the antipodes, etc., we gladly overlook; but, though we recognise that it is most truly only the defect of his high spiritual quality, we read with pity his contemptuous attack on human knowledge. 'Many,' he says, 'dispute about things which our authors have omitted, seeing that they do not conduce to the blessed life; and take up with lower things very precious time that should be given to their salvation. For what is it to me whether the firmament enclose the earth on all sides like a sphere, or cover it from above like a disc?' Worse still is his commentary on the creation of woman, which reads as though he had entered into both letter and spirit of the old Hebrew writer, whose word for 'female' recalls the earliest barbarism. $\mathrm{He}$ asks why God created woman, and his fertile 


\section{ST. AUGUSTINE AND HIS AGE}

imagination can find no reason whatever except procreation.

We have also a number of commentaries on the New Testament. ${ }^{1}$ The earliest of these is a short commentary on the Sermon on the Mount, and it was followed in 394 (or thereabouts) by glosses on the Epistles to the Romans and the Galatians. At the beginning of the fifth century he wrote his two books of 2uestions on the Gospels and the four books On the Harmony of the Gospels. The first book of the latter work is an attack on the pagans, and their comparison of Christ with Apollonius and Apuleius. In the other three books he proves that the Evangelists never really differ in their records. The question of the authenticity or trustworthiness of these records, which the modern world thinks of some importance, does not occur to him. $^{2}$ About the year

1 The task of identifying Augustine's works is greatly facilitated by the circumstance that both he (in his Retractations) and his pupil Possidius have left lists of his writings. I use the Migne edition, giving also (as a rule) the dates assigned by the Benedictines to each work. In the case of Augustine, the date of a work, from which a quotation is taken, is of extreme importance.

2 He raises it in his work Contra Faustum, but only to dismiss it as ridiculous. He relies on the tradition of the Church; though when Faustus urges the same argument on behalf of the Manichean Scriptures, he shrewdly rejects it, and demands more tangible proof of their inspiration. 
4I 6 he published his ten treatises (or sermons) on the Epistle of St. John, and his large work (consisting of one hundred and twenty-four sermons) on John's Gospel. The reader who turns over the pages of that copy of the latter work which lies on the shelves of the Museum reading-room will find ample, if not creditable, proof of the interest which the ecclesiastical world still takes in one of the sermons-the $26 \mathrm{th}$, commenting on the famous Eucharistic passage in the sixth chapter of John. Augustine speaks freely of the partaking of the body and blood of Christ, but neither here nor elsewhere does he anticipate the theory of transubstantiation. ${ }^{1}$ Finally, there are his Mirror of Holy Scripture, a compendium

1 No one questions that the Christians of his time had the sacrament of the Eucharist. But a close inquiry into the sense in which they conceived themselves to partake of the body and blood of Christ cannot find a satisfactory conclusion. Faustus says (in Contra Faustum) to Augustine: "You have the same veneration [religio] for the chalice and the bread as the pagans.' Augustine shirks the point, merely answering that the agape were not borrowed (this, by the way, being scarcely even a ' half-truth '-see his own sermon on the subject, p. 206). Faustus most probably meant the Mithraists by 'the pagans,' and we know how Jerome and other Christian writers were troubled about this parallel. The Mithraic 'Mass ' was strikingly

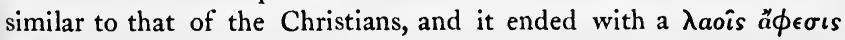
which is clearly the Greek for the Christian deacon's Ite, missa est. Probably the Christian feeling was as vague as that of the Mithraist with regard to the sacrament. 
of the moral and spiritual teaching of the whole Bible, published about the close of his life, and his four books On Christian Doctrine, three of which were written in 397 , and the fourth in 426 . The latter work is not only a compendium of sacred teaching, but also an instruction on the value of different sciences and methods in the interpretation of Scripture.

I have already said as much as the general reader will care to know about the dozen works Augustine wrote against the Donatists. They are chiefly occupied with a wearisome repetition of the dispute over Cæcilian's ordination and the integrity of his ordainer, with Scriptural and theological disquisitions on the repetition of baptism and the sanctity and unity of the Church. The anti-Pelagian writings will be enumerated in the next chapter. To the anti-Manichean works we have already seen must be added a book, Against Adimantus the Manichee (mainly a Scriptural study, written in 394), his large work Against Faustus (c. 400), his Debate with Felix the Manichee (404), his work On the Nature of the Good (published shortly after the preceding), and his book, Against Secundinus the Manichee (c. 405). Most of these works offer inconsider- 
able variations from his main attack on the Manichean position, but the Contra Faustum contains much interesting reading. Its thirty-three books are cast in the form of a dialogue with the distinguished Manichean bishop, and the words attributed to Faustus-and they are not Augustine's - make many a shrewd point. In his controversy with the Manicheans Augustine continually annihilated the position he himself took up in other matters. He invites Volusian and his pagan friends to join the Church on the principle that faith goes before understanding; when the Manicheans would seduce him with similar phrases, he says : 'I am not minded to believe what I do not understand; I came to learn what is certain.' ${ }^{1} \mathrm{He}$ demands faith in the Gospels without pretending to prove their authenticity; but when the Manicheans claim the inspiration of the Paraclete for their sacred books, he presses for proof. So it is with his onslaughts on other heresies, for there were few in his day that he did not encounter. He sends a list of them in the little work On Heresies which he wrote in his last years for the deacon Quodvultdeus. He has a small work Against the Fews, and another

1 So he says in his Contra Epistolam Manichai. 


\section{ST. AUGUSTINE AND HIS AGE}

(of the year 4I5) Against the Priscillianists and Origenists. On another occasion, apparently in 420 , a book is picked up by a Christian in the streets of Carthage. As no one knew either the person or the sect of the writer, it would seem to be safely negligible, but Augustine has to reply to it in a couple of books, Against the Adversary of the Law and the Prophets. In later years, too, he fell foul of the Arians or Unitarians. An Arian sermon seems to have fallen into his hands in $4 \mathrm{I} 8$, and he wrote a reply to it. His subsequent controversy with the Arian bishop, Maximinus, will be described in the next chapter.

Another group of Augustine's works has a distinctive interest ; they are those in which he deals as a casuist with questions of love and matrimony. It is well known that Augustine had views on these questions which even the modern world regards as perverse, but few imagine to what lengths his logical faculty compelled him to go. Brucker, premising a half-defiant and half-apologetic remark to the effect that 'a spade should be called a spade,' observes that 'the whole moral philosophy of the fathers was rather weak,' and that Augustine does not take his place 'in the first rank of philosophers.' ${ }^{1}$ Certainly, his views 1 Historia Critica Philosophia. 
on sexual relations, which were more or less shared by Jerome and Ambrose, were exceedingly unhappy. The root-idea of his whole philosophy is that there is something unhallowed in the very nature of sexual feeling, and especially sexual intercourse. The direct and obvious conclusion from this theory was a high estimate of physical integrity, and Augustine wrote a glowing eulogy of it in a small work On Continence, soon after his conversion (about 395). Five or six years later he was concerned to hear of the success of the monk Jovinian in attacking the cult of virginity, and he developed and defended the ascetic view in two works On Holy Virginity and On Conjugal Love. The latter work is, perhaps, the least attractive, though by no means the least interesting, of Augustine's writings. As the opinions expressed in it are usually concealed by his biographers, and are, nevertheless, particularly instructive, it may be well to enlarge a little on them. Matrimony being a divine institution, Augustine has to seek in it the element which consecrates, or legitimises, the sexual indulgence it implies. This he finds in procreation; though in one place he timidly adds its utility in removing the stress of temptation. From so narrow and 


\section{ST. AUGUSTINE AND HIS AGE}

forbidding a view of wedded love we may expect strange corollaries. In the first place, the pleasure which accompanies the act is unholy, and must not be desired or enjoyed. Then, since the maintenance of the race is easily assured, men and women of virtuous feelings should be exhorted to abstain altogether, and all men and women should abstain on holy festivals; though he goes out of his way to assert that the virginity of the heretic is of less value than the marriage of the Christian. Moreover, his theory of marriage enables him to meet very successfully the favourite objection of the Manichees-the polygamy and extensive families of the patriarchs. Since procreation was the chief matter, and the human race called for rapid increase in those early ages, the conduct of the patriarchs was clearly moral and commendable; 'they acted from a sense of duty, not a feeling of lust,' he says-indeed, one expects every moment that he is going to describe it as a painful necessity to them. ${ }^{1}$ On the other

1 In his earlier work, Contra Faustum, he confessed he 'did not yet fully understand the mystic life ' of the patriarchs. His progress had been rapid. Possibly M. Poujoulat and the other French writers on Augustine have omitted these interesting opinions lest their countrymen should claim that they are applicable in the circumstances of modern France, and wish to imitate the patriarchal virtue. 
hand, continence is more commendable in his own day; for Augustine, though he never explicitly grants it, and probably has no steady conviction to that effect, clearly shares the general apprehension that the end of the world approaches. But the most curious conclusion of all is one that the modern divine would reject with horror. If procreation is the essential aim, and a man's wife is proved to be barren, it follows, indeed, that he may still have relations with her to 'relieve temptation'-this Augustine grudgingly concedesbut how can you forbid him to have a concubine in addition, for the purpose of rearing children? Augustine cannot forbid him, he confesses, if the wife consents; 'it was lawful to the patriarchs: whether it is lawful now or no, I should not like to say.' Such is the peculiar and awful penalty of logically applying the ascetic Christian view of marriage. Nor does Augustine improve his position much when he considers the converse hypothesis of the man proving sterile. He will not allow the wife a paramour, because ' it is in the nature of things for there to be only one lord and master.' He has no idea of woman's equal worth and dignity. Fortunately, in the end, when he is confronted with a pagan application of 


\section{ST. AUGUSTINE AND HIS AGE}

his principles-Cato lending his wife to a friendhe throws logic to the winds, and says: 'In our marriages the sanctity of the sacrament is of greater moment than the fruitfulness of the womb.' But of the human holiness and beauty of marriage, of the sacrament of sexual love, this leader of men and light of many ages has no conception.

Three other works complete his theory of the foundation of family life. About the year 4I4 he wrote a book On the Blessedness of Widowhood. He was as strongly opposed as Jerome to the idea of remarrying. He exhorted widows to take a vow of continence, and declared that a breach of this vow by remarrying was worse than adultery. The practical conclusion that would be drawn from this principle in that age of widows is obvious enough. Here, also, he completes his patriarchal theory, contending that 'the holy women who lived under the Law' married out of obedience, not lust. His unfortunate ideas are further developed in the work On Adulterous Marriages, which he published about 4Ig. The marriages he has in mind are chiefly the unions of divorced people, which he naturally denounces. But he incidentally enunciates a theory which is largely 
reversed in our day. He says that men are more culpable for their infidelity than women. Why? 'Because they are men,' he bluntly replies, with his usual depreciation of woman. Still, Augustine would not allow that a woman could lie to escape violence; and, it is but just to add, he rejected the idea that it was lawful to lie for the purpose of gaining converts. These ideas occur in his work On Lying, of the year 395, and they are not inconsistent with the teaching of his later (c. 420) work Against Lying. Finally, I have to notice the work On Marriage and Concupiscence which he wrote in 419 . It is a development of one aspect of his unfortunate theory. Sexual feeling is an unmitigated evil, born of original sin, and quite accidental to marriage. Had our first parents not sinned, the propagation of the race would proceed to-day with the tranquillity and mechanical smoothness of respiration. The condition of Adam and Eve was even more philosophic than that which $\mathrm{Mr}$. Spencer seems to anticipate for the year 10,000 or so.

There is one other work of Augustine's of which the reader may reasonably demand a brief description. I have already referred to the book On the Work of the Monks, which he published 


\section{ST. AUGUSTINE AND HIS AGE}

about the year 400 . The book gives us a very interesting glimpse of the development of the monastic idea in Western Africa. The immediate occasion for the work was a controversy which then agitated the troops of monks, as to whether they were to work or no. We have already seen that the doors of the monasteries were thrown wide open, and crowds of members of the lower social orders flocked to them. Slaves embraced the black tunic in thousands; agricultural labourers, ruined curials, and general labourers from the towns, swelled the vagabond armies. These monasteries had absorbed the streams of gold that flowed from the palaces of Proba and Melania, and they were generously supported by the ordinary Christians. The result was that an enormous number of hypocrites entered, and the name of monk, Augustine says, was uttered with contempt in the country. No sooner had they donned the black robe and secured a sustenance than they spread over the provinces. 'Some of them,' says Augustine, 'sell limbs of the martyrs-if they really are martyrs; others broaden their fringes and phylacteries; others lyingly assert they have heard that their parents or relatives live in this or that country, and say they are going to visit them; 
and all of them beg and demand the fee of their lucrative poverty, or the reward of their pretended holiness.' Augustine severely condemned their idleness, and swept away their sophistry about Christ's exhortation neither to weave nor to spin. But once more he betrays his unpractical and unreasonable zeal. They are not to attack the disorder at its root by exercising some discretion in admitting neophytes. All who ask are to be admitted, ' even if they give no proof of emendation of life; even though it be not clear whether they have come for the purpose of serving God, or have only fled in idleness from a poor and laborious life, to be fed and clothed, and perhaps honoured by those who had once despised and beaten them.' Alas for Augustine's 'vastissimum ingenium'!

The remainder of his works, with a reservation of the anti-Pelagian writings, I propose to mention briefly. The chief religious, theological, and philosophical ideas they contain are presented in other parts of this work, in so far as they are characteristic, nor will any one seek even a compendium of the larger works in a biography of moderate proportions. There is, for instance, the large work On the Trinity, in fifteen books, which he began about the year 400 and published in 4 I 6 . 


\section{ST. AUGUSTINE AND HIS AGE}

It lies entirely beyond my field. The smaller work, the Manual on Faith, Hope, and Charity, which he published about $42 \mathrm{I}$, may be recommended as a short presentment of his fully developed views on moral and dogmatic theology. Some interest attaches, also, to the little book On the Care of the Dead, written about the same time, and therefore illustrative of his later views about the future state. Augustine commends the practice of praying for the dead, though he thinks the prayers will only be of service to them-he does not, unfortunately, develop this hint at a purgatory, and we know he maintains the eternity of hell -in proportion to the righteousness of their conduct on earth. Interesting, too, is the little work On the Catechetical Instruction of the Ignorant, written at the request of a Carthaginian deacon about 400 . It is a practical and painstaking manual of directions, pleasantly illustrating the side of early church-life which is indicated in the title. The admonition to wake up your drowsy subject occasionally with 'something seasoned with a little salt,' points clearly to Augustine's earlier years. There remain a host of works of a didactic or dogmatic character, which I will simply enumerate, with the dates assigned by the Benedictines, so that quotations 
may be appreciated: On Eighty-Three Different Questions (of philosophy and Scripture), begun in 388 ; On Faith and the Creed, a sermon delivered in 393; On the Christian Combat (c. 396); On Various 2uestions of Simplicianus (chiefly from the Epistle to the Romans and the Book of Kings), dated 397; On Faith in the Unseen (sometime after 399); On the Divination of the Demons (406-II); On Faith and Works (4I3); On Patience (4I8); and On the Eight Questions of Dulcitius (422 or 425 ). Besides these there are included in his works special sermons ' On the Creed, to the Catechumens,' 'On Christian Discipline,' 'On the New Canticle,' 'On the Fourth Day,' 'On the Flood,' 'On the Barbarian Epoch,' 'On the Use of Fasting,' and ' $O n$ the Destruction of the City,' mostly of unknown date. Nor can I omit to point out that a large number of his two hundred letters are really didactic or dogmatic treatises of considerable length.

The series of Augustine's works fitly ends with a unique achievement. I have referred at various times to his Retractations. This remarkable examination and criticism of his works was written in 426 or 427 , his seventy-second or seventy-third year. Mindful of the peril and 


\section{ST. AUGUSTINE AND HIS AGE}

the price of 'much talking,' the aged bishop resolved to review the whole of his writings before his death. He did not live to revise his letters and sermons, but we have a complete revision of his larger works, with important indications as to their date and object. 'Retractation' has not necessarily the meaning in Latin which we give to the term in English, ${ }^{1}$ as the hagiographers eagerly point out. Augustine's object was to revise, though he professed a willingness to 'retract' whatever was inaccurate or improper. We have, indeed, a number of withdrawals, and may measure Augustine's fortitude by that circumstance; though we find, for our consolation, that he is far more eager to explain away than to withdraw in that class of utterances where there is a real inconsistency between his earlier and later views-his early views on free will and later views on predestination. As to his willingness to retract his praise of Plato, or of human friendship, or of any of those gifts of nature that had gladdened and enriched his earlier years, we can but sorrowfully commend his high intention. The bloody pages of mediæval history rise before us when we dwell on his later ideas.

1 We have confused retrahere (to withdraw) and retractare (to revise or re-touch), and speak of 'retractation ' when we mean 'retraction.' 
From this authoritative list of Augustine's writings, as well as from the distinctive character of his work, the task of separating the mass of mediæval forgeries and inaccurate descriptions has been comparatively easy. No doubt, the list tended to encourage forgery at times. When one of the works mentioned was unknown to mediæval readers, some leisured monk would gladly undertake to supply the deficiency. In fact the eagerness to imitate the great doctor was so precipitate, that even works which Augustine says he had never written (on rhetoric, dialectics, etc.) were ascribed to him. However the mass of Augustinian literature has been very carefully expurgated by the Benedictines. In the result many writings have been rejected as indubitably spurious on which Roman Catholic writers still rely. This is notably the case with regard to the cult of the virgin. In Liguori's famous Glories of Mary, a fitting atmosphere for false quotations, we have a number of passages from spurious works, in which Augustine is credited with pronounced devotion to Mary. Still worse is the case of the Roman Breviary, in which a sermon attributed to Augustine is still read as his on the feast of the nativity of the 
virgin. Augustine never used language in any degree approaching that which is ascribed to him ; the sermon is an undisputed forgery. He had no personal feeling towards the mother of Christ, and no idea whatever of a public worship (the term used in the Roman Catechism) of her. $\mathrm{He}$ speaks with great respect of her, but has no idea of a practical relation of prayer, intercession, or veneration. With regard to the worship of the saints in general, the champions of Protestantism do not always appreciate the variations of Augustine's views. It is quite true that, as I have shown, he repudiated 'the worship [cultus] of. dead men' in his earlier works, but he yielded largely to the growing popular feeling in later years. In the sixteenth chapter we shall find a striking exemplification of this.

Probably most people of our own day who would make an impartial and adequate study of Augustine's writings would gather an impression of a great mind, more subtle than powerful, seeking judgment and expression in circumstances of exceptional hindrance. The occupations of his office permitted only a hasty and spasmodic direction of his thoughts to higher speculation after the year of his ordination. The intellectual condition 
of his time and his country did not afford the atmosphere of culture and philosophy which promotes a healthy development. The moral reaction of his mind after conversion, and the incessant brooding on the least humane dogmas of early Christianity, perverted his moral judgment and feeling. The bitter sectarian controversies he had to direct, and the responsibility for the destruction of error which his office seemed to lay upon him, narrowed his thoughts and hardened feelings which should impose a salutary check on a ruthless logic. A French writer who has made a careful and, it seems, impartial study of his 'system' passes this severe criticism on it: "Taken literally and in certain pronouncements, though these are usually episodic and have been abused, his teaching destroys liberty of conscience, justifies slavery, shakes the foundations of private property, reduces history to special pleading, enthrones theocracy, and at the same time, in various respects, discourages toil and the love of glory, hampers the march of civilisation, and paralyses the energy of all science, especially of the physical and natural sciences.' ${ }^{1}$ Each point in that indictment can be rigorously substantiated ; indeed, we v. M. Nourisson, in his Philosophie de Saint Augustin. 


\section{ST. AUGUSTINE AND HIS AGE}

have already seen the grounds for most of it. But, in justice to Augustine, these defects must be noticed in conjunction with the grave defects of his intellectual environment. Nor can we fail to see that they are frequently the defects of his qualities. If we are to regard as sublime his conception of the two cities, we cannot complain of his logical application of that conception to life. If it be a species of moral heroism to keep one's eyes fixed long on the sun, the ensuing inability to see the things of earth in their true colours and proportions must be pardoned. To present the matter in another way, there never was and never will be-there cannot be-a life that offers commanding heights of supernatural exaltation without corresponding dips below the level of common human feeling.

As to Augustine's erudition, Mr. Marcus Dods seems to express a general feeling when he describes it as 'varied, if not exact or profound.' Erasmus would not grant him 'a solid knowledge of the sacred sciences.' Mozley calls him 'a onesided interpreter.' Mosheim is equally critical. Baur observes that his scholarship was not equal to his intellect. One could hardly expect a different judgment after studying his career. 
For the first ten years of his mature life he was impelled by an extraordinary craving for knowledge. He devoured-I have explained why I cannot say he assimilated-the sciences of his day with great avidity. Even in this period, however, the world of Greek literature was closed for him, save for a few glimpses through the window of translation. Then came the reaction on his humane ardour, and a growing contempt for secular knowledge. In the years when his early and untutored cramming should have been corrected and completed, his Livy and Varro, Cicero and Plato, Horace and Ovid, his astronomy, history, and philosophy, were pushed aside with pious disdain. If that has increased his saintliness, he cannot complain that it has diminished the reputation of his scholarship. We may still admit, with Villemain, that he is 'l'homme le plus étonnant de l'église Latine.'

Further, one cannot make even a cursory study of Augustine's writings without noticing the profound changes of his thoughts even after his conversion. To construct a scheme of Augustine's 'system' - as the Germans say-would be to write a compendium of dogmatic theology. Most of the parts would be familiar enough, nor 


\section{ST. AUGUSTINE AND HIS AGE}

would it be any information to hear that Augustine accepted them - such are the problems of the nature of God, the Trinity, the Incarnation, and Scripture. The Christian teaching on these points he readily accepted with the Gospels. The chief changes we find were with regard to philosophy and his view of human life and human nature. In his earlier Christian years Augustine was bent on retaining his Platonist philosophy as the basis of his theology-as supplying what the modern theologian calls the indispensable preambula fidei. The central idea of it was the mind's intuition of eternal realities (truth and justice) and eternal truths (moral and intellectual principles). From this he proceeded with conflence to the existence and attributes of God and the spirituality of the soul. Signs and wonders were no longer wrought on earth or written on the heavens to compel men to listen to God; they must be induced by this philosophic reasoning. Hence reason was a divine gift and Plato a divine thinker. To point out the powerlessness of Plato and Varro to convince the multitude, and the hopeless obscurity of the popular mind in face of these high truths, was to conclude that God, in His justice, had given the world a more authoritative 


\section{THE WORKS OF AUGUSTINE}

teacher than Plato, and a more luminous and unfading gospel than that which was faintly traced in reason and conscience. Thus were the Incarnation and the Christian Bible introduced; and this Bible revealed features of the divine nature (such as the Trinity) which were above the gaze of reason, and positive enactments (baptism, church-membership, the necessity of grace, etc.) which were beyond the sphere of conscience.

In the Church of Rome to-day we have a perfect illustration of the change which came over Augustine's philosophy. In her academies, in the atmosphere of the study, her teaching is rationalistic. She leads the inquiring thinker up the very steps that Augustine ascends in his early works, and insists that ' reason precedes faith.' But in the streets and the market-places she reverses the order, and demands faith as a condition of understanding. So far is this true that the world at large is ignorant of her academic doctrine, and only knows Rome as the champion of authority and the rebuker of reason. When Augustine passed from his academy, his Epicurean fellowship, and monastic community, to the streets of life, his Platonism gradually faded, and his maxim was reversed. He found neither reason 


\section{ST. AUGUSTINE AND HIS AGE}

nor conscience in his people, but he found a willingness to accept any gospel that had weighty pretensions and an air of magic about its history. $\mathrm{He}$ found the few reasoners the most troublesome and rebellious of his flock. So by and by he formulated the famous ' faith goeth before understanding,' which has lived with his memory; and reason became a 'giftless gift of the enemy,' and Plato an 'impious man.' The Agora prevailed over the Academy.

The second and the greater change was in his view of man's nature and life. His first conception of the Christian teaching was as an additional light to his reason and conscience, confirming and enlarging their view of life, and bringing with it the promise of an undefined assistance to the will. It seemed at first to confirm the optimism he had recently learned from Plotinus. But this did not last long. The Manichean view of the world was still deeply rooted in his mind, and the moral reaction of his conversion only served to deepen his sense of the world's inherent evil. Moreover, the teaching of Genesis and of St. Paul soon suggested what seemed to be a way of reconciling the optimism of the Neo-Platonists and the pessimism of the Manicheans, and making a final peace with 
the world. The pivot of his optimism must be transferred to heaven, and then the earth and all the children of men could be freely handed over to the damnation of original sin. The ascetic teaching of Christ fully harmonised with this theory. Since it was only a finite devil, multiplied vaguely into 'legions,' that played havoc with the world, the supremacy of God was unimpaired ; and since man himself had caused this, by breaking a deliberate bargain, the sanctity and justice of God were untouched. On the other hand, the generosity and love of God had opened a higher world to man instead of the one he had forfeited, and we were to make our way thither with all the caution and anxiety which were demanded by its lofty character and the devilbeset nature of our path.

Reasoning in this way, Augustine receded gradually from the optimism of Plotinus, partly following, partly constructing, the familiar lines of Catholic theology. From this root sprang inevitably the most repellent of his opinions-the placid damnation of the unconscious babe as well as the appalling violence done to the conscience of the sincere Donatist, the contempt of sexual love (with its sinister results), as well as the extinction 


\section{ST. AUGUSTINE AND HIS AGE}

of patriotic feeling. The pressure and the horrors of the schism led to an exaggeration of one application of his theory, and Pelagius's attempt to restore some dignity to human nature occasioned another exaggeration. The one we have already studied, and the other we may now examine at some length. 


\section{CHAPTER XV}

\section{AUGUSTINE AND PELAGIUS}

If it was a singular advantage to the Christian Church to have such a man as Augustine at hand to meet the Donatist schism and the Pelagian heresy, it was, nevertheless, a peculiar mischance for Augustine himself that he had to confront those hostile movements in his later years. One is tempted sometimes to wonder how different the structure of Christian theology might have been, if Augustine had faced those systems in his earlier sacerdotal years, when his strong human sympathy still found something lovable in the city of men, and the gentle charm of the better NeoPlatonist ideas still lingered about his thoughts. Twenty years of episcopal experience had completed the transfer of his affection and his sympathy to the higher world. He had learned to trample on the consciences of his fellows for the sake of what now seemed to him a higher interest. 


\section{ST. AUGUSTINE AND HIS AGE}

Donatism had developed in him a crude idea of church-membership and outward conformity which has led to the writing of many pages of churchhistory that we would gladly suppress. And no sooner had Augustine returned to his spiritual charge after the defeat of the Donatists than a new danger arose. He heard that some monks were spreading the notion that human nature had sufficient nobility to appreciate and sufficient strength to achieve the highest standard of holiness; and forthwith he began to develop a doctrine of the utter degradation of our nature.

It seems unquestionable that some part of what we now call the British Isles gave birth to the author of one of the most amiable heresies that ever vexed the soul of Christendom. Jerome, always more lively than accurate, describes Pelagius in one place as 'a big, fat dog from Albion,' and in another as 'bloated with the pottage of the Scots' (or Irish). Prosper calls him 'the British serpent' ; and Augustine, Orosius, and Mercator frequently speak of him as British. ${ }^{1}$ Orosius adds that he was born of poor parents, and Jerome affords many brief descriptions of his person; but

1 But the statement that he belonged to the Bangor monastery, and his real name was Morgan, rests solely on a late and unconvincing legend. 
the whole of the clerical attacks on him-except that of Augustine-are vitiated by a most obvious bitterness of temper and personal hostility. One physical feature does seem to emerge with some clearness from the mass of reckless qualifications; he seems to have been a man of unusually large build. Jerome puts it that 'he could make more use of his weight than his tongue.' Jerome had - naturally - not heard of the ascetic St. Thomas Aquinas, who had to have a large slice cut out of the table of his monastery to accommodate the anterior part of his person. But the implication that Pelagius was as deficient in moral weight as he was redundant in physical, is one of Jerome's reckless turns of phrase. Augustine, who studied his works carefully, grants him, in several places, a considerable ability. He was much esteemed by the ex-senator Paulinus of Nola, and Jerome and Augustine had great difficulty in averting from him the admiration of many other cultured and noble Romans. The integrity and elevation of his character were acclaimed on all sides in his earlier years. Augustine spoke highly of his virtue until his obstinacy in heresy made that no longer possible; and even then Augustine did not sanction the charge of sensualism urged 


\section{ST. AUGUSTINE AND HIS AGE}

by the heated Orosius and Jerome. The hagiographers naturally conclude that he was virtuous until he fell into heresy, and then he contracted the vices his enemies attribute to him. The course of our narrative will probably suggest that the only change was in his antagonists, especially as the heresy is found in his earliest works.

There is an eagerness shown by ecclesiastical writers to trace the germs of Pelagianism to the eastern Church. No doubt there is some plausibility in the notion of tracing the theory of the strength of human nature to the energetic Origen, but the eastern temperament in general would be even less disposed than the Roman to originate so sturdy a heresy. The long reluctance of the East to condemn it is easily understood for other reasons, as we shall see. Even if the eastern monk Rufinus had influence over Pelagius, as Marius Mercator says, it does not at all follow that he inspired the heretical idea. We know with certainty only that Pelagius won great repute for holiness and asceticism at Rome in the first decade of the fifth century. The monastic idea had travelled swiftly from Rome to Gaul and Britain, and had created a number of fervent monasteries, besides inspiring a number of unattached or 
itinerant monks. But we can well imagine the effect of an acquaintance with the low moral quality of the Roman Church on the stalwart ascetic. Probably enough his earnest exhortations were met with an Italian shrug of the shoulders and an appeal to the weakness of human nature. Certainly the moral vigour of the individual was not promoted by the rapidly growing system of external aids to sanctity - the worship of the saints and of relics, and the multiplication of sacraments and sacramentals. Pelagius was not a priest. He had not the sacerdotal bias in favour of ritual and objective sanctification. We need no speculation about Oriental ideas to help us in understanding the growth of his main idea. He would at once insist on that natural strength of which he had so clear a consciousness, especially if we may assume, as we seem entitled to do, that he was a man of sober temperament and equable life. And if the scriptural doctrine of original sin were pleaded by more passionate temperaments and moral cowards, as pointing to a primeval corruption of our nature, he would resent it as a pretext or subterfuge, and endeavour to explain away the words of Genesis and St. Paul.

We know enough of the Roman Church to 
356 ST. AUGUSTINE AND HIS AGE

learn without surprise that Pelagius incurred no reproach as long as he remained in the eternal city. His elevated character and zeal attached many of the best of the Italians to him, such as Paulinus, and a large number of the Roman clergy. In fact, there is an amusing and instructive illustration of the quality of his teaching. He wrote three works during his stay at Rome, one on the Trinity, another comprising a collection of moral maxims from Scripture, and a third which consisted of a commentary on St. Paul's Epistles. In the latter work his characteristic ideas were bound to find expression, and in point of fact Augustine detects many heretical passages in it a few years afterwards. But not only did this work receive nothing but approbation from the Christians of Rome, it was actually attributed at a later date to Pope Gelasius, and then, for several centuries, to Jerome himself, the most bitter opponent and critic of its real author. That is a unique and precious fact in the history of heresy. Further, he wrote a long letter on nature and grace to Paulinus in 405 , in which Augustine's practised faculty discovered-ten years afterwards -a complete betrayal of his heresy.

Pelagius was brought into conflict with Augus- 
tine's ideas a few years before their first personal encounter. An African bishop who was disputing with him at Rome quoted the well-known passage from the Confessions: 'Give us that Thou commandest, and then command what Thou wilt.' Pelagius 'warmly resisted' the sentiment, says Augustine. If we have not already the strength to observe the Commandments, the command itself is dishonoured, and moral indolence is perilously encouraged. But it was not until the year 410 that he met the great African bishop. He left Rome in 409, when Alaric was threatening the city, and sailed for Syracuse with his pupil and companion, Cœlestius. Cœlestius was an advocate of some capacity, who had been converted to an ascetic life by Pelagius. Prosper affirms that he was sexless, from a congenital defect, so that he was providentially equipped with a fine qualification for the defence of Pelagianism. However, the two monks proceeded with the famous Rufinus to Syracuse, and shortly afterwards sailed for Hippo. Augustine was occupied with the Donatists at Carthage at the time, and they went to see him there. They saw little of each other, however, owing to Augustine's preoccupation, and Pelagius soon departed for the 


\section{ST. AUGUSTINE AND HIS AGE}

East, leaving Cœlestius to sow the good seed in Africa.

It was, apparently, in 410 that they met at Carthage, but we do not find Augustine speaking of the new heresy until about 4I2, when the conflict opens. In that year Cœlestius sought ordination at Carthage, and the bishop, Aurelius, directed that the new ideas which were attributed to him should be examined by a synod of his province. A deacon named Paulinus drew up the indictment, and succeeded in fastening the charge of heresy on the candidate for the priesthood. The points of the charge were: that Adam was created mortal, and would have died whether he sinned or no, and that his sin entailed no punishment on his offspring; that infants are born in the condition of Adam before his fall, and that even if they are not baptized they have eternal life; that the race does not die in the sin of Adam, nor rise again in the resurrection of Christ; and that the Law, no less than the Gospel, introduces men into the kingdom of heaven, and there were men living without sin even before the coming of Christ. Thus the simple Pelagian idea had already been confronted with texts from Scripture and points of ritual, and was rapidly growing into 
a theological system. Augustine was not present at this synod (he belonged to the Numidian, not the Proconsular province), but it is easy to see his inspiration in the arguments of Paulinus, and shortly afterwards he occupies himself openly with the disputed questions.

Cœlestius was excommunicated, and departed for the east; but, as at Rome and in Sicily, he had left a number of disciples behind. Augustine begins to discuss errors about nature and grace in his letters and sermons. Theologians usually observe that Augustine was eminently fitted by his own spiritual experience for combating the new doctrine. The Pelagians, on the other hand, maintained that their doctrine was not new; that it was the Manichean taint, or a lingering feeling of ubiquitous devilry, that inspired Augustine's novel versions of original sin and the primeval corruption of human nature. It will be remembered that Augustine had readily surrendered his Manichean theory of the dual character of human nature for a Christian dualism which seemed to meet the facts of consciousness equally well. Instead of a divine soul and a diabolical soul, he came to believe in an element of corruption warring against a divinely implanted 


\section{ST. AUGUSTINE AND HIS AGE}

ideal. The compact with Adam and the original sin shifted the responsibility of this corruption from God, so that he felt himself free to exaggerate it as much as he pleased without a shadow of reflection on God's sanctity. And what could be more apparent, both in the memory of his own struggle and in the world about him, than this appalling corruption and resistance to every elevating influence? Paul had been so convincing because he started throughout from this fact of consciousness. And when St. Paul went on to say that only 'the grace of God' could lift us above this awful corruption of our nature, he seemed to be pointing an almost equally obvious moral. In this way aboriginal corruption and the necessity for 'grace' (vaguely conceived as divine assistance) were facts both of consciousness and Scripture for Augustine. He felt no disposition whatever to explain away St. Paul's vigorous presentment of that dual fact, nor could he sympathise with, or see any honest reason for such an extenuation. Moreover, he was quite insensible to the force of the ethical considerations that moved Pelagius - that it was unjust to punish the race for the $\sin$ of Adam; that it was barbarous to damn an infant that had never known 
$\sin$; that to deny the power of the will was to deny its responsibility; and that to create a defective nature and then introduce a complementary super-nature was unworthy of infinite wisdom. These objections never touched the heart of Augustine, and his subtle mind coldly disposed of them without difficulty. The modern cynic is apt to observe that they were really disputing whether the power for good which both admitted to exist in man (or there would be no question of responsibility and personal sin) was to be called natural or supernatural, will or grace. However that may be, each had his fact of consciousness-Pelagius his sense of power and liberty, and Augustine his sense of corruptionand his ethical or scriptural superstructure; and in the stress of controversy neither could calmly survey the whole ground. Pelagius entirely believed that Augustine's outlook was vitiated by his long attachment to Manicheeism; and Augustine was sincerely unable to see any reason except a criminal pride for his adversary's exaltation of human nature.

This, at least, it is gratifying to discover : Augustine long maintained an attitude of gentle and affectionate forbearance towards the persons of 
Pelagius and Cœlestius, and he never, even in the most heated stages of the conflict, descended to the vulgarity and bitterness of Jerome and Orosius. In his earlier letters (140, 143, I 57 , etc.), sermons (I70, I 74, I75, etc.), and works, he refrained from mentioning Pelagius and his friend. It was not until Pelagius resorted to undeniable equivocation that he began to attack his person.

It was in 41 2 that Augustine wrote his first work against the new ideas. Marcellinus, the religious-minded official who had presided at the Donatist conference, consulted him on the Pelagian theories which he found prevalent in Carthage, and he was answered in a work On the Deserts and Remission of Sin. The practice of baptizing infants had become one of the most severe tests of the new ideas, and Augustine at once laid down his well-known belief with regard to them. The unbaptized infant will be punished, he says, but 'very lightly'; it cannot be with Christ, so it must be with the devil (book r.). When Marcellinus urges the ethical objection to this, he says (book III.) that he 'cannot refute their arguments' (he affected to do so later), and can only point to the Scriptures. Marcellinus 
was perplexed by his statement that, although man could with the divine assistance, avoid all $\sin$, no human being, except Mary, had succeeded in doing so. This elicited another anti-Pelagian work, On the Letter and the Spirit, in which he gives a finely conceived and skilful explanation of the maxim that 'the letter kills and the spirit quickens.' The light of conscience and of Scripture may only serve to illumine a man's divergence from the moral ideal. In the following year Pelagius wrote a friendly letter to Augustine, and received an equally friendly and respectful answer. In 4I4, however, the conflict became more pronounced. A certain Hilary wrote to Augustine from Sicily, complaining of the alarming notions which flourished there since the visit of Pelagius and Cœlestius, and Augustine replied at great length. Then he was approached on the subject by two young men of culture whom Pelagius had converted to the monastic life. Timasius and James seem to have heard of Augustine's denunciation of the new ideas, and they send him one of Pelagius's writings. The work confirmed Augustine's opinion of the danger of the heresy, and he replied to it in a book On Nature and Grace. In this work he boldly meets the ethical 


\section{ST. AUGUSTINE AND HIS AGE}

diff:culties of Pelagius, affirming that the condemnation of the race to eternal punishment for Adam's sin was perfectly just, and the sentence could with absolute justice have been rigorously carried out on every individual. Shortly afterwards two Sicilian bishops send him a list of Pelagian arguments which is circulating in their province, and he repeats his criticisms in a work On the Perfection of Human Fustice.

But the chief interest of the struggle passes for a few years from west to east, and we cannot follow Augustine's later activity very well unless we glance for a moment at the course of events in Palestine. Cœlestius had received ordination at Ephesus, and Pelagius was continuing his mission at Jerusalem, untroubled save for the impotent vituperation of the monk of Bethlehem, when a hot-tempered young Spanish priest came upon the scene, straight from the feet of Augustine. I have described how Orosius came to Hippo in 4I5, chiefly to consult Augustine on the heresies of the Priscillianists and Origenists. Augustine sent him on to Jerome, and it is not unnatural to assume that he recommended an interest in the proceedings of Pelagius at Jerusalem. At all events we learn from Orosius (our 
only authority, unfortunately) that when the bishop of Jerusalem held the customary synod of his clergy in July 4I 5 , he invited both Orosius and Pelagius to attend. Orosius was summoned to speak first, and he told of the condemnation of Colestius and the work which Augustine was writing against Pelagius. The monk was then introduced, and informed of the accusation. 'What is Augustine to me?' he coolly asked. And when the young zealot hastened to reply, the bishop quietly interjected, 'I am Augustine here,' and bade them discuss the matter peaceably. In the end Pelagius was acquitted, and the question was referred, at the demand of Orosius, to the decision of the Latin Church. ${ }^{1}$ Orosius retired to Jerome's cell for consolation-the charge of heresy having been shifted to his own shoulders during the synod-and the Latin world was soon acquainted with the situation.

The next move of the orthodox Latins was equally unsuccessful, and hardly more creditable. Towards

1 It appears that the bishop, John of Jerusalem, snubbed the young Spaniard for his zeal on the following day, and Orosius wrote an extremely immoderate narrative of the proceedings. He contends that the interpreter (the Palestinians not knowing Latin) garbled his statements, and then explains that he knows this from some of the priests present who, like Pelagius, spoke both Latin and Greek. 
the end of the year 4 I 5 , a couple of Gallic bishops, Heros and Lazarus, who had been deposed or driven from their sees, appeared at the court of Eulogius, bishop of Cæsarea, and laid an accusation against Pelagius. Of the character of the accusers it is impossible to judge; Zosimus, bishop of Rome, speaks very unfavourably of them, though Prosper affirms their innocence. However, these men had drawn up an indictment, consisting of a number of quotations from the writings of Pelagius (many of which were not merely 'abbreviated,' as they said, but entirely distorted), the condemnation of Cœlestius, and Augustine's letter to Hilary. Pelagius complained that they were instigated by the pious and peaceful community at Bethlehem. Eulogius referred the matter to his provincial synod, which met at Diospolis soon afterwards, and Pelagius was once more acquitted. The accusers failed to appear, one of them, Augustine says, being seriously ill. Pelagius was confronted with their libellus, and, partly by explaining misrepresentations, partly by disavowing the condemned propositions of his disciple, partly, it must be admitted, by ambiguous answers and equivocation, obtained a certificate of orthodoxy from the fourteen bishops. Shortly 
afterwards Jerome's monastery was taken by storm at Bethlehem. Some of the buildings were burned down, and one or two servants killed, but Jerome and his friends, with the Roman ladies who had settled there, found safety in 'a fortified tower' ; though this outrage was never seriously laid to the charge of Pelagius.

Probably one of the first intimations Augustine received of the result of the synod was a letter from Pelagius, covering a sort of apologia, in which he apprised the world of his absolution by the eastern bishops. Augustine proceeded cautiously, and waited impatiently for the return of Orosius. We have a fragment of a sermon in which he speaks with respect and reserve of the synod; 'perhaps Pelagius was corrected,' he says. Even when Orosius arrived with a letter from the ex-bishops and a glowing account of the proceedings in the East, he still maintained a certain reserve about the absolution of Pelagius, and spoke with respect of the synod. But there was clearly a pressing need of action in the western Church. The new ideas were spreading at Carthage and Syracuse. They already claimed the patronage of important clerics at Rome, such as the priest (afterwards pope) Sixtus. Augustine flew to 
Carthage, and before the end of the year the full power of the African Church was bent on the destruction of the heresy. ${ }^{1}$

Some time before the end of 4 I 6 a provisional synod met at Carthage. Augustine read the letters from the East to the sixty-nine bishops, and it was decided to anathematise Pelagius and Colestius, and request the bishop of Rome to join with them in the anathema. The same decisions were reached at the Numidian synod (at Mileve) of sixty-one bishops. Both the letters sent to Pope Innocent in the name of these synods were written by Augustine, and in a third letter he and Aurelius (of Carthage), Alypius, Evodius, and Possidius, made a more personal appeal to the bishop of Rome. The points of the charge against Pelagius are not new, but there are one or two incidental features of interest. In the first place, Augustine expresses in the third letter an apprehension of certain practical consequences from the Pelagian ideas. One is tempted to think that the clergy must have perceived, with some

1 The acta of the synod of Diospolis reached Augustine about the end of 416 or the beginning of 417 , when he wrote his work On the Proceedings of Pelagius. Forgetting his pious trust that Pelagius had been 'corrected,' he now wrote that he thanked God his suspicions were confirmed-that Pelagius had deceived the bishops. 
anxiety, that the Pelagian idea gravely threatened their ritual and administrative structure. If nature be morally self-sufficient, ${ }^{1}$ the complex system of the Church, in so far as it is framed for administering grace rather than for worship, becomes largely superfluous. Augustine indicates this fear in his third letter (ep. I77), though, it must be admitted, it plays a very small part in the controversy. On the other hand, the appeal to Rome is an event of great interest, and has been invested with no slight importance. Roman theologians do not fail to notice it in proving the supremacy of the pope. From what I have said in connection with the Donatist controversy, it is clear that the Africans had no notion whatever of papal supremacy, and certain episodes which will be described in the next chapter will show that Augustine's attitude towards the Roman pretensions never changed. But there were special circumstances for the appeal to Rome in 416 , as Augustine clearly indicates in his letters; and the flattering terms in which the pope is addressed are

1 But it must be noted that Professor Mozley and other students think it is not established that the Pelagians wholly rejected grace as an internal operation of the Spirit. The truth is, there were all shades and degrees of opinion amongst them, and we have only the works of their adversaries. 


\section{ST. AUGUSTINE AND HIS AGE}

entirely outweighed by the subsequent action of the Council of Carthage, as we shall see. In the third letter Augustine introduces their appeal in these words: "For we have heard that there are many at Rome, where he lived so long, who favour him for one or other cause.' There were, indeed, as we shall see presently; and the Africans felt that the heresy must be crushed out at once in the whole Latin Church. They, therefore, ask that 'the authority of the Apostolic See be added to their own modest statutes,' and that Innocent, whom 'the Lord, by a special favour of His grace, has placed in the Apostolic See, and given such a character in our days that we should be guilty of negligence if we failed to suggest to thy holiness what seems good for the Church,' should 'apply his pastoral diligence to the great dangers of the infirm members of Christ.'

Innocent was naturally elated at the honour which this fortunate heresy seemed to have secured for his see. His three replies breathe the dignity of the sovereign pontiff in every line. He takes remarkable pains to point out that they are only following the time-honoured custom of appealing to Rome, whilst his delight at the novelty floods the whole letter. He confirms their decisions with 
great pomp and severity, pronounces Pelagius's book to be dangerous and blasphemous, and excommunicates the two heresiarchs. This was in January 4I7; Augustine's politic letters had obtained a quick and complete victory. The joint spiritual authority of Rome and Africa fell with a heavy weight on the Pelagians, and Augustine trusted to extinguish the last elements of obstinacy by his rhetorical labours. On the 23 rd of September he preached at Carthage the celebrated sermon (No. I 3 I), in which he did not say: 'Rome has spoken.' ${ }^{1}$ But he spoke with triumph and gladness of the condemnation of the heresy, and trusted soon to hear the last of it.

But alas for the slender threads by which the fortunes of dogmas hang! At that very moment a Roman vessel was speeding across the sea with a letter in which a new bishop of Rome reversed the decision of his predecessor, and gravely

1 It is worth while pointing out that the much-quoted Roma locuta est, is not even a just representation of Augustine's words. It should at least be Roma etiam locuta est, indicating that the force lay in the joint enactment of Africa-and Rome. The full text is : - Already the decisions of two councils have been sent to the Apostolic See, and the reply has come to us. The cause is finished.' The phrase, duo concilia missa sunt, is curious, and has no parallel in Augustine. However, even admitting it as it stands, it is something very different from Roma locuta est. 


\section{ST. AUGUSTINE AND HIS AGE}

rebuked the zeal of Augustine. Innocent had died on the I 2 th of March, and been succeeded by the Greek Zosimus. Whether or no Cœlestius heard that the new pope had not a keen eye for dogma it is impossible to say, but he soon quitted the East, where he had been less fortunate than Pelagius, came to Rome, and appealed to the pope. Zosimus assembled his clergy in the basilica of St. Clement for the discussion, but once more the ex-bishops failed to appear in support of their indictment, and Coelestius averted condemnation. The bishop reserved his judgnent, with an evident leaning towards acquittal, and wrote at once to chide the African bishops for their uncharitable haste in listening to the accusers. The letter contains some pompous remarks about the dignity of the Apostolic See, and concludes with a delightful and innocent comment on Augustine's zeal in the matter: 'I admonished Cœlestius and all the clergy who were present that these ensnaring questions and foolish strifes, which destroy rather than build up, proceed from an idle curiosity.'

Before the African bishops could recover from this shock, Pelagius had also appealed with success to the tolerant bishop of Rome, and been pro- 
nounced ' a good Catholic' and of ' unquestionable faith.' Before he heard of the death of Innocent he forwarded a defence and profession of faith to Rome. Luckily his documents found another judge. They were read before a Roman synod, and, as Zosimus reproachfully assured the African bishops, the hearers could hardly restrain their tears when they reflected that so holy and admirable a man had been condemned. Pelagius and Cœlestius were acquitted with honour, Heros and Lazarus were excommunicated and denounced, and the African bishops were once more rebuked.

Augustine was almost solely responsible for the African condemnations, and to him, therefore, we justly look for an explanation of the subsequent proceedings. Unfortunately, he tells us little of his action, and nothing of his feelings. In later years he spoke with quiet forbearance of the letters of Zosimus, but his reverence for the bishop of Rome's 'pastoral diligence' was threatened with premature extinction. Prosper tells us that the African bishops held two great councils within the next six months, and that Augustine was 'the soul' of the proceedings. The first council or synod is not a little obscure. Probably Aurelius and Augustine hastily sum- 


\section{ST. AUGUSTINE AND HIS AGE}

moned the nearest bishops to Carthage and drew up the reply to Zosimus. Their letter has 'not been preserved,' and thus the Roman historian has probably been spared a painful task. But Prosper relates that two hundred and fourteen bishops were present at the synod, and has preserved this instructive paragraph of their letter : - We hereby ordain [constituimus] that the sentence which Innocent passed on Pelagius and Cœlestius from the chair of the apostle Peter remains in force until they make a clear profession' of the Augustinian view of faith and justification. We do not know the date of this synod. However, Zosimus made no reply until the 2 Ist of March 418, when he intimated to the African bishops a considerable change in his sentiments. They were quite wrong, he said, in supposing that he had given complete credence to the professions of Cœlestius. His decision was still in reserve; in fact, new matter had recently been placed before him, and he broadly hints that he is likely to condemn the heretics. This letter reached Carthage on the 29th of April, and found two hundred and five (Photius says two hundred and twenty-six) bishops assembled there from all parts of Africa for another council. They met 
in the basilica of Faustus, under the presidency of the two primates (of Carthage and Numidia), on the Ist of May. The letter of Zosimus seems to have relieved the strain of the situation, and they were content to formulate nine canons against the heresy, and forward these to the bishop of Rome that he might give them the additional weight of his acquiescence.

But it would be wrong to suppose that the defiance of the African bishops had of itself effected the conversion of the Roman see. Zosimus had announced his change of policy at the end of March. At the end of April Honorius issued a decree in which the weight of the imperial authority was cast on the side of the Augustinians. It seems unquestionable that Augustine and his colleagues had once more appealed to the secular power, in the failure of their rhetorical armament. The document is entitled a ' rescript,' and one ancient manuscript even says explicitly that it was a reply to the Carthaginian synod. Augustine apparently confirms this when he says to Julian the Pelagian, ' if the reply had been given in your favour'; and in the following year, 419, Honorius sends a letter to Aurelius and Augustine (a remarkable 


\section{ST. AUGUSTINE AND HIS AGE}

honour for a simple bishop) in which he states that the decree against the heretics was given at their direction. We are forced to conclude that the African bishops appealed to the emperor when they received Zosimus's letters (virtually acquitting Pelagius). Count Valerius seems to have been their instrument, and he was supported by the ex-vice-prefect of Rome, Constantius, who had turned monk at Rome, and led the antiPelagian party there. On the 30 th of April Honorius pronounced sentence of banishment and confiscation on the heresiarchs and their followers. Rome was profoundly distracted by the controversy. Zosimus and Sixtus (afterwards pope) favoured the Pelagians, and 'the heresy was rampant in the city,' as the imperial rescript said. But the earnestness of Augustine and the successful enlistment of the imperial interest were political considerations of some gravity. Zosimus was most certainly aware of the intrigue that was proceeding at court, and the knowledge cannot have been without influence on his letter of the 2 Ist of March. When the rescript appeared and the letter of the second Carthaginian synod arrived, he summoned Cœlestius to appear once more before him and his clergy. The heretic 
did not like the nature of the new documents in the case, and fled to the East. $\mathrm{He}$ and Pelagius were then condemned and excommunicated, and Zosimus issued a circular letter (tractatoria) in which he demanded the submission of the Italian bishops under pain of deprivation of their sees. The execution of the sentence was intrusted to the imperial forces, and thus the humanists of the fifth century were at length definitively cast out of the Church in the western empire.

In the meantime Augustine maintained a vigilant opposition to the heretical ideas wherever they appeared. $\mathrm{He}$ wrote a long letter to Paulinus of Nola, the early friend of Pelagius, urging him to confirm the faith of some of his wavering clerics. From this letter it appears that there were ultra-Pelagians who granted the child a power of choice even before it left the womb. He wrote to Sixtus, artfully congratulating him on his conversion. But a more interesting outcrop of the heresy claimed his attention about the end of 4I7. We have seen how the young Roman heiress, Demetrias, took the veil of virginity in 4I4, and Pelagius imitated the group of distinguished clerics (Augustine, Jerome, Innocent, etc.) who sent her letters, or treatises, of encourage- 
ment. Pelagius was invited to do so by her mother Juliana, ${ }^{1}$ and he was not unwilling to enlarge on so striking a proof of the power and dignity of human nature. He sent her an admirable treatise of spiritual direction, encouraging her with an introductory laudation of ' nature.' $\mathrm{He}$ reminds her that God is the author of our nature and our will, extols the virtue of preChristian philosophers and prophets, and describes how much more is required of those who live under the 'grace of Christ.' It is evident, however, that he means by grace nothing more than the external advantages - the gospel, the divine example, etc.-of the Incarnation. The letter was greatly appreciated and much copied, until a copy fell at length under Augustine's keen eye. It had not the name of the writer, but Augustine probably suspected its authorship, and wrote to ask the name of Juliana, and warn her with

1 This he expressly says in his letter, yet all the hagiographers rebuke him for his gratuitous and insidious interference. Cardinal Rauscher talks of his 'poisoned cup,' and represents the mother Juliana as 'more distressed at this spiritual peril of her daughter than ever mother was over an attempt on the bodily life of her child.' The truth is that Augustine finds Juliana rather hard to convince that the book is heretical; and poor Jerome had again to suffer under the allegation of authorship for several centuries, whilst the book circulated admiringly in the Church under his own name. 
extreme anxiety against the errors of the work. Juliana seems to have been none too well disposed for his zealous interference, and he takes great pains to teach her the evils of Pelagianism. But the most virulent passage he has found in the work is, he explains, the observation that 'thy beauty of body and thy wealth may be accounted as the gift of others, but spiritual wealth no one can give thee but thyself.'

About the same time other friends of his, whose acquaintance we have made, were nearly seduced by the 'dog from Albion.' Albina and Pinianus and Melania, who had by that time settled in Palestine, met Pelagius and attempted to restore him to orthodoxy. As usual, the persuasive monk turned their criticism into admiration, and they then wrote to ask Augustine's view of the matter. He replied by the composition of a fresh work on the old lines, having the title Of the Grace of Christ and Original Sin, in which he again expounded his theory and proved the discrepancy of the Pelagian teaching.

But a new champion of the Pelagian cause, in a slightly modified form, appeared in the West. The exaggerated ideas of original sin and predestination put forward by Augustine provoked a 


\section{ST. AUGUSTINE AND HIS AGE}

wide and sincere revolt, which was not entirely quelled for more than a century. When the tractatoria of Zosimus announced his change of views, or of policy, to the Italian bishops in the summer of $4 \mathrm{I} 8$, no less than eighteen of them refused to submit, in spite of the very material argument of the imperial spears on which it chiefly relied. They were accordingly driven from their sees. The leader of them, Julian, bishop of Eclanum in Apulia, was the son of a friend of Augustine's, Memorius, and it was with some regret that Augustine found it necessary to exert his whole power against him. Julian contemptuously described the orthodox theory of original sin as 'a mere popular murmur,' and declared it had been thrust on the Church by 'a rascally conspiracy.' He regarded Augustine's system as a revival of Manicheeism, and he and his friends familiarly spoke of the orthodox as 'the Manicheans.' He held that Augustine's view of the creation and fall was inconsistent with the divine power and wisdom, that he cast dishonour on marriage, and that his theory of grace left no room for free will and personal responsibility. He wrote two letters in defence of his action: one to the bishop of Rome, in 
which he severely censured Zosimus for suddenly abandoning the Roman position under the pressure of the Africans, instead of calling a general Council, and denounced the appeal to force ; and a second to the bishop of Thessalonica, in which he pointed out the moral and religious consequences of the Augustinian teaching. These letters were forwarded to Augustine by Boniface, who had succeeded Zosimus in the Roman see, and he answered them in his work Against the Two Letters of the Pelagians. A little later, when Count Valerius told him that the Pelagians made much of his apparent depreciation of marriage, he wrote a book On Marriage and Concupiscence, in which he developed the views I have already described. His controversy with Julian and the Italians was long and monotonous. In 42 I he wrote a work in four books Against Julian, and we have also several books of a large, unfinished work against the same writer, on which he was engaged in his last years. The heresy long resisted both ecclesiastical and imperial pressure in Italy and Gaul. We find traces of it until about the end of the fifth century. Pelagius and Cœlestius had retired to the East, where they enjoyed a greater freedom until after the death of 
their great adversary. But in $43 \mathrm{I}$ the Eastern Church embraced the Augustinian ideas at Ephesus, and the champions of human nature sank into obscurity. Pelagius is said to have died in a small town of Palestine at an advanced age, and Cœlestius disappears from the chronicles. Julian is said to have opened a school in an obscure Sicilian town, and died there in 454 .

In the meantime the ethical protest against the Augustinian ideas assumed the milder form which is known as semi-Pelagianism. Human nature was not disposed to surrender its dignity without a struggle. There is an ecclesiastical tradition that all heresy is born of pride and flourishes only in an atmosphere of disorderly feeling. One might have expected even the boldness of a theologian to shrink from applying this maxim to the Pelagian heresy, but we have seen that neither historical fact nor intrinsic probability has deterred him from making the attempt. However, semi-Pelagianism, like the more pronounced heresy, took root in a soil of exceptional purity. A monk named Cassian, who had learned sanctity in the schools of Bethlehem and Egypt, and had then founded two monasteries at Marseilles, began to expound a compromise between the certainly 
anti-scriptural opinions of Pelagius and what $\mathbf{M}$. Nourisson ventures to call the 'inhuman and revolting' doctrine of Augustine. He acknowledged that we have all died by the death of Adam and live by the resurrection of Christ, but he protested against the idea of a total corruption of human nature and a predestination to eternal life or death without regard to individual merit; he also held that grace was not usually granted until it had been merited by a motion of good will, that it might be lost, and that perseverance in grace depended on the will. Another compromise was attempted by the monks of Adrumetum, with whom I will deal later. Augustine was not the kind of man to allow purely rational considerations to interfere with the course of his theological reasoning. He sternly denounced the compromise in his works On the Predestination of the Saints and On the Gift of Perseverance. The question of perseverance had not been much discussed in the earlier stages of the struggle, and the compromise of Cassian only served to drive Augustine to the bitterest consequences of his principles. His ideas on this point are too well known for me to enlarge on them. The will is a mere automaton, worked solely by grace. The 


\section{ST. AUGUSTINE AND HIS AGE}

first movement must come from grace no less surely than the last; we cannot merit that indispensable factor in the moral life, nor can we retain it to the end by our human efforts. Absolutely without regard to the merit of the individual (in the way of co-operation or rejection) God has decreed his distribution of grace, on which eternal life or eternal damnation morally depends, as Cassian saw. The Christians of Gaul long resisted these harsh opinions, but by the middle of the sixth century even their modified vindication of human nature had entirely ceased. ${ }^{1}$

1 Gibbon has said that 'the real difference between him [Augustine] and Calvin was invisible even to a theological microscope.' He should have said 'except to a theological microscope.' I was once the happy possessor of such an instrument, and I perceived the difference. Perhaps I was wrong in saying that Augustine's logical consecutiveness was unhampered by any merely humanist feeling. It was in this he differed from Calvin, who calmly handed over millions of mortals to a positive and deliberately decreed damnation, whilst Augustine was reluctantly forced to leave their damnation as an unwelcome consequence of his views-the reprobatio negativa of certain Roman theologians; and whilst Calvin ruthlessly fulminated the automatism of the will, Augustine made inconsistent efforts to reconcile with his principles the granting of some native dignity to it. 
EPISODES OF HIS CLOSING YEARS 385

\section{CHAPTER XVI}

\section{EPISODES OF HIS CLOSING YEARS}

FOR the later years of Augustine's career we have only to narrate the incidents of unusual interest which distracted him from the work we have already described. His correspondence and his judicial work increased with the advance of age and the progress of his reputation through the Roman world. On him chiefly devolved the task of watching the restless movements of the proscribed heretics, schismatics, and pagans; and he had projected vast commentaries on Scripture, which he slowly accomplished between 4I 5 and 425 . So untiring, indeed, was his literary activity, that we shall find him calmly toiling at a huge anti-Pelagian work whilst the fierce Vandals are pressing against the walls of Hippo, and the great church he had built up in Africa lies in ruins about him. It is this continuous labour that chiefly invites our astonishment and admira- 
386 ST. AUGUSTINE AND HIS AGE

tion in Augustine's later years. However, we have already seen the character of the work he was normally engaged upon, and it only remains to give a few illustrations of the exceptional occupations which reveal his person to us in so many different lights after the great conference of $4 \mathrm{I} 8$.

Immediately after the conference at which Augustine and his colleagues so courteously corrected the errors of the bishop of Rome, a second controversy arose, of less importance in itself, but so irritating as to destroy the last particle of an inclination to submit to the Roman pretensions. The majority of the bishops had returned to their sees, and Aurelius, Augustine, and fourteen other bishops, were dispatching the detailed business of the synod, when a fresh deputation from Rome appeared. Some time previously one of Augustine's bishop-pupils, Urbanus of Sicca, had deposed and excommunicated one of his clergy at that town for improper and scandalous conduct. This Apiarius had appealed to Rome; and the bishop of Rome, ever ready to make precedents of interference in foreign provinces, had persuaded himself that the priest had been injured. He had, therefore, sent Faustinus, bishop of Potentina, with a 
couple of Roman priests, to demand the reinstatement of Apiarius. Faustinus was a pompous and fussy Italian with large ideas of Roman supremacy, as will appear, and the Africans were little reconciled to the substance of his demand by the manner in which he urged it. Aurelius at once summoned the neighbouring bishops to meet the legate. When Faustinus was politely asked to state the basis of the pope's claim to interfere, he appealed to two canons of the Nicene Council which provided for recourse to Rome. The African fathers at once referred to their copies of the Nicene canons (brought from the Council by their own bishop of Carthage), and were astonished to find no trace of the two canons Faustinus had mentioned, and Zosimus had quoted at length. ${ }^{1}$ However, they promised to admit the new canons until the matter could be properly investigated, and to reopen the question of Apiarius. But they also enacted that in future no priest or deacon who appealed to a church beyond the sea against

1 I may state at once that the canons in question were added at the subsequent council of Sardica. Hefele would have them to be of equal importance, but the course of our narrative will show that the Africans thought otherwise. Indeed, it is very clear from the records that they entertained very unflattering suspicions about the Romans and their canons from the beginning. 
his bishop would be admitted to communion in Africa. The rule was that a priest should appeal from his bishop to the primate of his province, and from him to a provincial or general council.

It appears that Augustine was then sent with other bishops to make an inquiry into the scandal. His Catholic biographers generally observe with some complacency that in 418 he was delegated by Zosimus to hold an inquiry at Cæsarea into some unknown business. Cardinal Von Rauscher, who gives the Apiarius incident nearly in full (though in phrases which are not 'offensive to pious ears'), very justly observes that it must have been the commission of Aurelius to settle the Apiarius question which took him to Cæsarea (in Mauretania) in 4 I 8 . He himself says (ep. I90) that it was 'a necessity imposed by Zosimus,' and Possidius says 'the letters of Zosimus had compelled him' to go thither. These observations are quite consonant with the idea that he went at the request of Aurelius, arising out of the letters of Zosimus; and there is no clear trace of other matters in dispute between Zosimus and the Africans. Augustine only mentions incidentally the synod he held at Cæsarea, but he tells of two other adventures which illustrate his wonderful 


\section{EPISODES OF HIS CLOSING YEARS 389}

alertness and energy. The former Donatist bishop of Cæsarea, a very capable man of the name of Emeritus, still rebelled against the Church (and the law), and was probably hiding in the neighbourhood. When he heard of Augustine's arrival, he came into the town. The expectation of one of those public disputes which had so much charm for the Africans at once animated the whole town. Augustine was informed of the appearance of Emeritus, and instantly buckled on his spurs. He met Emeritus in the street, and after a few friendly passages invited him to the church (the poor man's own basilica). Emeritus consented, but when Augustine ascended the steps of the apse and began to interrogate him, he sullenly refused to debate, and the crowded congregation had to be content with a discourse from Augustine.

The other incident Augustine tells recalls his success in crushing the martyr-feasts at Hippo. At Cæsarea there was a peculiar tradition, going back far into the past history of the place, of holding an annual faction-fight. Even families were divided in the encounters, and for several days the citizens stoned and fought each other with fatal results. The clergy had been unable 
to induce the people to abandon this cherished custom of the town, and, as the festival occurred during Augustine's visit, he was invited to preach against it. He won a signal oratorical triumph. Before his sermon had proceeded far, the murmurs were changed into applause, but he continued with increased fervour until he saw the whole congregation in tears. The caterva, as the traditional fight was called, was never again held at Cæsarea.

Augustine himself has led us to this digression, and we may now return with him to the question of Apiarius. The charges seem to have been proved, but the priest asked forgiveness, and Urbanus was induced to restore his priestly office, and allow him to exercise it in a small town or village of his parœcia. At what date this was done we cannot say, but we find Faustinus and the two priests still at Carthage when Zosimus died on the 26 th of December. His successor, Boniface, confirmed the commission to the Italian bishop, and at length, on the $25^{\text {th }}$ of May 4I9, a general synod of the African bishops (to the number of two hundred and seventeen) was held at Carthage. The ill-chosen legate somewhat exasperated the bishops by his pompous claims of compliance with 
the Roman demand and resentment of their scepticism about the canons, but in the end it was decided to procure authentic copies of the Nicene canons from the bishops of Alexandria, Antioch, and Constantinople, and to regard the two Sardican canons as valid in the meantime. In their letter to Boniface they apprise him of the conclusions arrived at 'in charity, indeed, but not without laborious altercation.' If these canons had been found in their copies, they say, they 'would have been spared certain intolerable things they do not care to mention'; but they 'trust they will not have to endure that pompousness any longer.' 1

When Atticus, bishop of Constantinople, and Cyril, bishop of Alexandria, sent authentic copies of the Nicene canons, and there was still no trace of the two quoted by Zosimus, the feeling of the African bishops must have been strongly aroused against Rome. Augustine is provokingly silent on the whole question and the issues it involved.

1 See this and the subsequent letter to Cœlestine in Labbé's Collectio Conciliorum, ad ann. 419 and 424. Father Hefele does not quite justly translate the letters in his History of the Councils (English translation). For instance, he makes them say Urbanus had 'complied with the pope's request ' before the council. The bishops say that 'Urbanus had corrected what needed correction,' but they do not gratify Boniface with the expression inserted by Hefele. 
However, Apiarius once more fell into disgrace a few years later, and the controversy was reopened. Disgraceful conduct was proved against the priest by his new congregation, and he was again excommunicated. He fled to Rome, the bishop-now Colestine I.-received him to communion (so indecent was the haste to assert the prerogatives of the Roman see), and the Africans were insulted by the same Faustinus being sent to demand his reinstatement. The African bishops hastened to Carthage, where they held a general synod in 424 . The proceedings are not recorded, or the records have not been preserved, but the bishops admit in their letter to Cœlestine that 'there were stormy sittings for three days.' Faustinus demanded compliance with Cœlestine's orders more arrogantly than ever, and the African bishops, fortified by their new copies of the canons, warmly resented the Italian intervention. At length Apiarius reduced Faustinus to silence by confessing his guilt of all the crimes alleged, and the Roman party retired from the struggle. But the Africans followed up the retreat of the legate with a letter ${ }^{1}$ which must have made Cœlestine weep for the loss of Africa. They complain that Faustinus ' insulted the whole 1 See in Labbé (not Hefele), loc. cit. 
assembly, pretending to assert certain privileges of the Roman Church,' and in conclusion they ' earnestly beg that in future you will not too readily lend your ears to those who come to you from here, nor receive into communion those whom we have excommunicated; for thy Venerableness will easily find that this has already been enjoined by the Council of Nicæa. . . . The fathers did not detract from the dignity of the African Church by any of their enactments. They most prudently and justly provided that all affairs should be disposed of in the places where they arise; nor did they think that any province would be refused that grace of the Holy Spirit whereby the priests of Christ may prudently discern and hold fast to equity; especially as any priest is free to appeal to a provincial, or even a general council, if he be dissatisfied with a judgment. Unless, indeed, there is any one who can think our God will give His inspiration of justice to one single person [unicuilibet], and deny it to so many priests assembled in council.' They go on to remind him that 'the judgment of a transmarine see' is hardly likely to be sound, seeing the distance and the difficulty of obtaining witnesses ; and they ' do not find it laid down in any synod of the 
fathers' that the Roman bishop has a right to send legates into their provinces. Cyril and Atticus have confirmed their suspicion that the two canons were not genuine, and they beg he will send no more legates 'lest we should seem to introduce the empty pride of the world into the humble Church of Christ.' As to Faustinus, they could not tolerate him in Africa much longer. So much for the recognition of Roman prestige in Africa in the fifth century.

Augustine is, as I said, singularly silent about the whole episode. We cannot even trace his influence in the great council of 424 . However, in the meantime an incident occurred which brought him into communication with the bishop of Rome. On the outskirts of his parœcia, some forty miles from Hippo, was the small town of Fussala, where he had established a mission. A retired official had built a chapel there over a handful of soil which had been brought from Palestine, and was held in great veneration. The district was almost entirely Donatistic, and the earlier priests whom Augustine had stationed there had been blinded, maimed, and variously ill-used by the fierce Circumcellions. As the schism yielded, Augustine had converted Fussala into a separate bishopric, and in 4 I 8 he was 
summoned thither to find an occupant for the see. He had chosen a worthy priest of his own community, and had invited the primate of the province to lay hands on him, when the candidate withdrew at the last moment. Not liking to give the primate a fruitless journey (so he said afterwards), Augustine cast about for a suitable candidate amongst the clerics who accompanied him. He selected a young man named Antony, a lector from his own episcopal seminary, who had been under his charge 'from his earliest boyhood.' Bishop Antony developed propensities which had escaped the eye of Augustine. In 422 his people rebelled against his authority, and demanded his removal. He was acquitted by the synod which Augustine convoked of the grosser charges brought against him, but the accusation of covetousness and corruption was sustained. Augustine proposed to leave him in office with diminished authority, but the people refused to retain him in any capacity, and he was forced to retire.

However, Antony persuaded the Numidian primate that he had been wronged, and the primate-so Augustine says in his letter to Cœlestine-advised him to appeal to Rome. Pope Boniface, naturally more lenient to those who supported the Roman policy by appealing, 


\section{ST. AUGUSTINE AND HIS AGE}

decided that Antony was innocent and must be reinstated ' if his depositions were correct.' He sent legates to Fussala to enforce his decision, but died shortly afterwards and was succeeded by Colestine. The Fussalenses at once appealed to Colestine, casting the blame of the incident on Augustine, on account of his hasty choice in 418. But they do not seem to have gained much, and rumours came to Hippo that the Roman commissioners were about to enforce the pope's decision by the use of the imperial forces. Augustine then wrote himself to Cœlestine, and seems to have succeeded in inducing him to abandon the matter. The letter (ep. 209) cannot be quoted as evincing any disposition on Augustine's part to accept the Roman claims. It is by no means defiant in tone, yet it contains a threat to resign his own charge if Cœlestine insists on the reinstatement of Antony, and it seems to discover no other feature of authority in the Roman interference beyond the threatened use of the imperial forces. Either the letter gained its object, or the African triumph of the following year (424) forbade any attempt to enforce the support of Antony from Rome.

Another incident of the year 423 , which we 
learn from Augustine's letters, was a rebellion in the nunnery which adjoined his house. Augustine's sister had been superioress of this convent until her death (some years previously), and her successor had directed the community in peace until the year 423 . Then she seems to have changed the chaplain (prepositus) of the house, and her spiritual daughters rebelled. Augustine complains (ep. 2II) that the noise of their quarrels was audible in his own house. They sent for him to come and settle the dispute, but he refused to do so. Had he done so, this familiar and trifling episode of an intrigue and quarrel in a nunnery would not occupy us in the twentieth century. As it was he wrote a letter, which we still have, chiding them for the scandal. But the chief interest of the event is that it occasioned the writing of the famous Rule of St. Augustine. After a few reproving words Augustine goes on to frame a rule of life for the nuns, and this has been taken (with a few masculine modifications) as the foundation of more than one monastic rule. It expresses the moderate asceticism which we have already noticed in Augustine. For instance, whereas Jerome urges 'the adult virgin' to shun the bath altogether, Augustine not only permits, 


\section{ST. AUGUSTINE AND HIS AGE}

but recommends, the use of the bath 'about once a month'; and the nuns must not go to the baths in less than a company of three. If there was one purely human virtue that Augustine recognised it was cleanliness. His ideal was rather one of sobriety and plainness of life for a moral purpose than of the infliction of actual suffering.

Augustine exhibited a notable credulity from almost the beginning of his ecclesiastical career, as we have seen, and there are events of the year 424 or 425 which seem to prove that it grew with his advancing age. Some years before that date the body of St. Stephen is said to have been discovered at Jerusalem. With the dramatic discovery itself -owing to a nocturnal communication from no less interesting a spirit than that of Gamaliel-we have no concern. But somewhere about the year 424 a portion of the discovered body was brought to Hippo, and was enshrined with great honour in a small chapel opening into the chief basilica. ${ }^{1}$ The opposition to the 'cult of dead men' was not the only error of his youth which Augustine had outlived. He had likewise surrendered the idea

1 I have already given Augustine's rebuke to those who questioned the authenticity of the relics: 'Let no one dispute: the will of God requires faith, not questions.' 
that 'miracles were no longer performed,' as well as his early weakness for the production of evidence. He eagerly received the relics into his church, and still more eagerly welcomed the miracles which now began to occur daily. In two years he drew up the libelli of no less than seventy miracles that were wrought at Hippo. Most of these were, of course, cases of diabolical possession, a disease on which we no longer have the opportunity to experiment. But there were three cases of raising the dead to life, which might disconcert the sceptic if Augustine had not written about that time a chapter on these miracles in his City of God (bk. xxii). He there describes a case of miraculous resurrection. A woman was weeping in distraction over her dying child, when the thought of the relics occurred to her. The child died (so she and Augustine believe), and she at once ran off to church with the body, and had it restored to life.

But another miracle occurred about the time we are dealing with which has many features of interest. With the multiplication of miraculous shrines there appeared a number of cosmopolitan patients who often conveyed their infirmities from country to country for a number of 
years. Two of these came to Hippo, and occasioned some very lively scenes in the basilica. The story told by the youth (his companion was his sister) was that they had lived at Cæsarea in Cappadocia (a thousand miles or so away), where their father had died, leaving a widow and ten children. The eldest son insulted his mother one day, and she at once repaired-' in one of those fits of temper which are so familiar to that sex,' says Augustine-to the baptismal font in the basilica to curse him with due form and legality. She met a demon on the way, who persuaded her to include the other nine in her malediction, because they had not taken her part. The curse was answered-Augustine believes this without a shudder-and the ten children were seized with 'a horrible tremor of the limbs.' They then dispersed over the Christian world to seek a remedy at some miraculous shrine. After fruitlessly visiting the shrines of Italy the brother and sister had been warned in a vision (during sleep) to go to Hippo.

For fifteen days before Easter Paulus and Palladia visited the church assiduously, and excited considerable interest and sympathy. On Easter morning, when the church was thronged 


\section{EPISODES OF HIS CLOSING YEARS $40 \mathrm{I}$}

with worshippers, the youth, who was praying at the shrine, fell insensible to the ground, and presently awoke completely cured. The people ran to the apse and loudly informed Augustine of the occurrence. Augustine had the youth brought before him, and then preached a brief sermon on the subject amidst ringing applause from the people. Paulus dined with the bishop that day, and told him the story of the malediction. On the following day Augustine preached again on the miracle, and made the two strangers stand beside his chair whilst he narrated their story, and pointed out the contrast of the still infirm sister and the recovered youth. But Palladia persevered with her prayers, and in the middle of his sermon on the following day-he was telling the story of the baby-Augustine was apprised by loud shouts from the vicinity of the shrine that she also had been cured of her 'tremor.' It is with a string of stories like this that Augustine concludes his great work The City of God, which he completed about that time. Quantum mutatus ab illo!

Not long after these events Augustine's congregation was agitated by a less agreeable sensation. It was known throughout Africa that the 
Hippo seminary followed a kind of monastic rule, and in point of fact it had furnished a dozen of its ablest and most earnest bishops to the African Church. Great was the excitement, therefore, and deep the sorrow of Augustine when it transpired that one of his priests had died in possession of a large sum of money. Augustine was not ignorant of the existence of this money, but Januarius, the deceased priest, had always pretended that it belonged to his daughter, a minor living in a nunnery at Hippo. Januarius had increased his guilt by passing over both his children and bequeathing the money to Augustine's church. Augustine never accepted such legacies. However, his chief concern was to restore the credit of his seminary, and he at once instituted an inquiry, and discovered that nearly every priest and deacon under his charge possessed slaves or houses or some other property. He summoned the people to the basilica, and told them that he had been forced to abandon his rule of ordaining no cleric who would not consent to live under the system of personal poverty and common ownership. He had warned his clergy that those who were unwilling to dispose of all their possessions before the Epiphany 
could continue in the clerical office, but would have to reside outside the seminary.

On the morning of the Epiphany a very large congregation gathered in the basilica to hear the result, which we learn from his sermon (No. 356). All his clerics had decided to part with their possessions, and he was therefore encouraged to renew the rule of poverty - the root of the whole scandal. He would lay hands on no man who would not submit to it: ' $\mathrm{He}$ may appeal to a thousand councils against me; he may take ship to wherever he likes' [poor Rome !]; ' he can go wherever he will; but, with the Lord's help, he shall not be a cleric where I am bishop.' $\mathrm{He}$ then makes an interesting and chatty review of all his clergy. This one is going to manumit his slaves to-day; that one never had a penny; the other has sold his property, or holds it in conjunction with a brother, and cannot withdraw for the moment. One cannot say that Augustine increased in practical judgment with his advance in years.

In October of the same year $(426)$ he was summoned to Mileve to settle a dispute about the succession to the bishop of that see, who had died. The system of election by the people was 


\section{ST. AUGUSTINE AND HIS AGE}

so imperfectly organised, and lent itself so readily to corrupt practices, that quarrels were frequent and sanguinary conflicts not unknown. On his return, therefore, Augustine reflected whether he might not devise a means of averting such a danger from his own church. He was now in his seventy-second year, and could not expect to serve the Church militant much longer. Besides, the duties of his office pressed heavily on him, and left him little time for writing. He had some years before obtained a promise from his people that they would not approach him with their troubles and disputes on five days out of the week, but the promise had not been fulfilled. On the other hand, he was prevented by the canons from appointing a coadjutor; he remembered how the rule had been violated in his own ordination. However, he decided to ask the people to accept one of his priests as bishop-designate, and then he would be able to surrender most of his occupations, that were not strictly episcopal, to his future successor.

Again, therefore, the people were summoned to the basilica for special business. The presence of two brother bishops added solemnity to the occasion, and all the clergy attended in the 


\section{EPISODES OF HIS CLOSING YEARS 405}

sanctuary, whilst the official notaries prepared to make a record of the proceedings. Augustine reminded the people of his age and occupations, and proposed his young deacon, Heraclius, for the post of what we should now call 'vicargeneral,' with the right of succession to the see. 'What do you say?' he asks of the people before him; 'let me hear your assent, and let the notaries record it.' At once there rang through the basilica a medley of consenting shouts, as the notaries duly register in the report of the sermon (No. 355). 'Thanks be to God, thirty-eight times,' ' Praise be to Christ, twenty-three times,' 'So be it, twenty-five times,' are some of the marks of approval. Augustine proceeds to describe the merits of Heraclius, and the cry of ' he is worthy and deserving' fills the church ' eighteen times.' And even the aged bishop's simple reminder of his approaching end is greeted with a 'Long life to Augustine, thirteen times.' The young deacon was accordingly ordained priest, and recognised as Augustine's successor. We must accept Augustine's estimate of his virtue, but the two sermons of his which we have do not reveal any unusual mental gifts. The youth had little opportunity to shine in his promised dignity. 


\section{ST. AUGUSTINE AND HIS AGE}

Augustine lived for four years afterwards, and within a year of his death Hippo was a mound of smoking ruins and its parœcia a desert waste.

By that time there were five churches and a few minor chapels in the town, and about a score of missions in the parccia. The ordination of Heraclius must, therefore, have afforded some relief to the bishop, and he fell upon the Pelagians, as we have seen, with a quite youthful energy. With the obstinacy and literary work of Julian in Italy, and the semi-Pelagian reaction on Augustine's own views, he had abundant exercise of his controversial powers. One curious incident that occurred about this time will serve to illustrate the situation. Two monks of the monastery of Adrumetum (near Carthage) were travelling in Italy, where they secured a copy of Augustine's letter to Sixtus. They brought the treasure to their monastery on their return, and it circulated amongst the brethren. The result was a grave disturbance of the peace of the community. Abbot Valentine wrote to tell Augustine that his monastery resounded all day with the arguments of two rival schools of interpreters of the letter, and Augustine had to send a long explanation of his teaching (ep. 216) and two works. Eventu- 
ally, two of the monks came to consult him at Hippo, and the controversy was ended. About the same time there came to Hippo a monk named Leporius, who had blended the humanism of Pelagius with a kind of anticipation of the humanism of Nestorius; he held that Mary was the mother of Christ, but not of God. He had been excommunicated for his errors in Gaul, and had come to Carthage with a few companions. There Augustine convinced him of his errors-a rare triumph-and had the satisfaction of seeing him publicly recant his heresy in the church at Carthage.

The abjuration of Leporius did not present an unfamiliar spectacle to the people of Carthage. In his I 3 Ist sermon Augustine invites them to bring obstinate heretics to the clergy whenever they encounter them, and a public confession of the great crime was not infrequently enjoined. But there were occasions when this public exhibition assumed a character which is revolting to the modern mind. Such an incident is recorded by Possidius (c. I6) and Augustine himself in his work On Heresies (c. 46). The date of the affair is not given, but it certainly occurred in Augustine's later years. It will be remembered that 
Augustine had opened his Christian polemic with an attack on 'the morals of the Manichees,' but had been forced by the Manichean bishop Fortunatus to confess that he had observed no irregularity during his association with them. He still hinted in his works, however, that the gross stories which were told of their elect by the Catholics were quite consonant with what he knew of their tenets. The third stage of the controversy began after the imperial decrees against heretics, when captured Manicheans were publicly interrogated in the churches and courts on the secret practices of their elect, or clergy.

It is a case of this kind that Augustine and Possidius relate. Two Manicheans had been detected at Carthage, and Augustine was requested to interrogate them before the people. The first was a girl of twelve years, and Augustine solemnly put the child through a searching examination on the sordid stories that were current about the Manichean sacrament-or exsecramentum, as the Catholics called it. The girl confessed what Augustine and his colleagues desired, and the second culprit was introduced and confronted with the confession. This was a woman of maturer years, who claimed to be a nun, or sacred 
virgin, of the sect, and indignantly denied the charges. However, they had a rough and ready way of finishing disputes about chastity in those days. The woman's claim was disallowed by the obstetrix, and she thereupon confessed that the incredibly sordid legend was correct. $^{1}$ This picture of the aged bishop taking a child of twelve, in presence of a large congregation, through details that go far below the deepest depths of our trials in camera, is omitted with great delicacy by the hagiographers. But I think it tells us something of Augustine-pure as his intention was-no less than of his times.

One other experience of Augustine's with regard to the Manicheans seems to belong to this period. He was one day horrified to discover that one of his sub-deacons, an elderly man, was a Manichee, and was secretly propagating his faith. This Victorinus had been ordained at Cæsarea, and had been admitted into Augustine's clergy;

1 Augustine says, De Haresibus, c. xlvi.; ' inspecta' [ab obstetrice], 'et quid esset inventa, totum illud turpissimum scelus, ubi ad excipiendum et commiscendum concumbentium semen farina substernitur' [ad conficiendam Manichaorum eucharistiam], 'indicavit.' According to Augustine, the later Manicheans held that the elements of light were largely imprisoned in semine animali, and they certainly held that light was released from anything when it was eaten by the elect. That was a good foundation for a legend, at least. 


\section{ST. AUGUSTINE AND HIS AGE}

though it is impossible to say how long it was before he was detected. The old man begged Augustine to instruct him in the orthodox faith and allow him to retain his order at Hippo, but he was expelled from the town at once. Augustine relates this (ep. 236) to Deuterius, bishop of Cæsarea, whither he expects the sub-deacon will go. He urges Deuterius not to admit the man to penance until he has betrayed the names of all the Manichees in the province! That detail suffices of itself to relegate the occurrence to Augustine's later years.

To have crushed two formidable heresies and a schism was already an unprecedented service on the part of Augustine, but he sprang with alacrity at every other living error that was brought to his notice, and in his last years he came into conflict with the Arian (or Unitarian) heresy. The Goths and Vandals had, as is well known, been converted to that form of Christianity, and in 428 a detachment of the Gothic troops was sent to Africa, for a purpose which we have to consider presently. An Arian bishop, Maximinus, accompanied the troops, and he was sent, for some reason or other, to Hippo by the commander, Sigisvult. Here the Arian encountered 


\section{EPISODES OF HIS CLOSING YEARS 4II}

Augustine's zealous lieutenant, Heraclius, and was induced to hold a debate with Augustine in the basilica. Maximinus consented, and a large ccngregation, including 'many nobles,' hastened to the church. The dialogue has been preserved, but is of little interest, as the Arian tenets are familiar. Augustine is arrogant and overbearing in the fulness of his faith, telling his opponent 'not to talk so much if he is not willing to learn'; and Maximinus, though a model of politeness and cultured ease, has at length to protest that Augustine 'talks like a man who has the imperial support at his back, not according to the fear of God.' The Arian is really the most brilliant debater Augustine has encountered, and has by no means the worse of the duel. But he had to return to Carthage, and leave the debate unfinished. Augustine heard that the Arians were boasting at Carthage of a victory, so he returned to the contest with great vigour in two books Against Maximinus. I have already related a somewhat similar experience with Count Pascentius, another Arian. 


\section{CHAPTER XVII}

\section{A SADDENED TERMINATION}

THERE are few instances in ecclesiastical history of so vast and impressive a work being accomplished by one man as that which Augustine achieved in the Church of Africa, but there are fewer still where the work has tumbled into ruins before its creator's eyes. That was the sad fortune of Augustine in his closing year. At the very moment when he was completing his rout of the enemies of the Church-refuting the heresy of the Goths; when Manicheeism and Donatism were almost extinct and Pelagianism was in its agony; when the African Church was attaining a supreme and worthy distinction among the provinces of Christendom; the army of the Vandals was pouring across the Straits of Hercules, and the flames of burning temples leaped into the heavens. Whilst Augustine laboured steadily at his final and comprehensive destruction of the 


\section{A SADDENED TERMINATION}

Italian Pelagians--laboured to correct the errors or atone for the indifference of Rome-the hand of the destroyer was laid on the Church of Africa, and was to take it to pieces, stone by stone, before his aching eyes. The last picture of earth that he gazed upon was that of the Western Church, for whose purity and power he had sacrificed so much, disappearing in a flood of Arian and heathen violence.

Whatever may have been Augustine's feeling as to the more philosophic aspect of this stirring devastation, he had the painful consciousness that an error of his own figured conspicuously in the chain of human causes. The Count of Africa at that time was an able Roman general of the name of Boniface, whom Procopius calls 'the last of the Romans.' Boniface was a religious-minded man, and had a profound respect for Augustine. About the year 420 Boniface had lost his wife, and had thought of retiring to a monastery. Augustine, in his singular and ill-blended mixture of prudence and zeal, had very justly urged him to remain at his most useful post in the imperial service, but had advised him to make a private vow of chastity. Boniface had done so; and when, in 428 , he summoned the Vandals into 


\section{ST. AUGUSTINE AND HIS AGE}

Africa, Augustine could only recall with bitter sorrow that but for his own counsel Boniface would be praying in some obscure monastery instead of blundering in a net of political intrigue.

There are few of us to-day who will share Augustine's grief that he did not withdraw the ablest soldier of the empire from its service, however strongly we may think it would have averted or postponed the disaster. Moreover, true to his spiritual ideal, Augustine was not so much concerned about the material disaster as about Boniface's moral lapse. In 422 Boniface had been sent to Spain on an imperial commission, and there the blue eyes and fair locks of a Vandal princess had seduced him from his vow. There was this consoling circumstance, says Augustine, that he compelled Pelagia to become a Catholic and Trinitarian before he married her. However, his daughter received Arian baptism, and Arian prelates had influence in his court. It was even said that he was not content with the affection of his own wife. Still he fought the battles of the empire with great skill and vigour, received exceptional honours at Rome in 425, and was loyal to the empress-mother in her most anxious moments. 
Boniface had a rival, Aetius, who is associated with him by Gibbon in deserving the phrase of Procopius. Aetius was a jealous and unscrupulous courtier, and he is said by Procopius to have conceived a diabolical plot when he saw the high favour of Boniface. ${ }^{1}$ He reminded Placidia, the mother of Valentinian III., of Boniface's connection with the Vandal king, and suggested that she should recall him from Africa, where he might raise a formidable rebellion. At the same time he informed Boniface that the recall meant disgrace and death to him, if he obeyed it. Boniface refused, and the refusal was represented to Placidia as confirming the suspicion of Aetius. Very soon Boniface was in open rebellion, and defeated three armies that were dispatched against him. But he knew the resources of the empire too well to suppose that he could permanently maintain the diocese of Africa with his one legion and a few less disciplined auxiliaries. He sent a trusted officer to treat with the Vandal kings in Spain, and formed a fatal alliance with them. Gonderic and Genseric stipulated that there should

${ }^{1}$ De Bello Vandalico. Mr. Hodgkin (Italy and Her Invaders) thinks the story not above suspicion, but some such key to Boniface's conduct seems necessary, and the details are plausible enough on the whole. 


\section{I6 ST. AUGUSTINE AND HIS AGE}

be an equal division of the provinces into three parts as the reward of their services. They had already secured their position in Spain, but the renowned fertility of Africa easily tempted them to favour the alliance. Boniface accepted their terms, and in the spring of 429 the whole Vandal nation, with whom the Alani were now amalgamated, moved towards the southern parts. The Spaniards gladly afforded the use of their ships for the crossing of the straits, and the lawless army began its march upon Hippo and Carthage.

Augustine did not write to his friend Boniface until about the end of the year 428 . Never had there been a case in which his mediation was more urgently demanded, yet he seems to have watched the development of the situation with a feeling of helplessness. He explains (ep. 220) that he was deterred from writing to Boniface earlier by the fear lest his letter should fall into the hands of his enemies. The reason is not very satisfactory, but certainly the situation was one of extreme delicacy and difficulty. When he does at length find a trusty messenger he can only write a letter which must have conveyed neither light nor consolation to the unfortunate count. He frankly confesses that he has no 'secular 
counsel' to offer; he does not attempt to attenuate the gravity of the injury that has been done to his friend. And the spiritual counsel he offered was hardly likely to influence Boniface. Unfortunately, Augustine's chief concern was about the violation of his vow of continence, and so the main point of his letter is to induce Boniface either to abandon his wife and retire to a monastery or to secure her consent to the renewal of his vow.

Boniface had more practical friends at court, and these found an opportunity of bringing Placidia to a more reasonable attitude during the absence of Aetius from Ravenna. Count Darius was sent on a pacific message to Boniface. They met at Carthage, and the production of the letters of the intriguer at once removed the cause of the estrangement. ${ }^{1}$ Explanations were speedily given and accepted, and the count returned to the allegiance of the empress. But when Boniface turned to reason with his Vandal 'allies,' he found that he had delivered Africa into their fatal clutches.

Gonderic had died, or had been murdered,

${ }^{1}$ Hatzfeld quite gratuitously grants Augustine the credit of the reconciliation. 


\section{I 8 ST. AUGUSTINE AND HIS AGE}

shortly before the Vandals marched down to the coasts of Spain, and the fierce, skilful, and resolute Genseric was left in supreme command. Mr. Hodgkin says that if Attila was the Napoleon of the fifth century, Genseric was certainly its Bismarck. A brave soldier and astute general, as well as a cunning and unscrupulous politician, Genseric probably saw his ultimate goal from the start. In the month of May he mustered his army of fifty thousand warriors ${ }^{1}$ on the north-west corner of Africa, and directed their greed and cruelty towards the distant cities of Numidia and the Proconsular province. The tall, fair, blue-eyed, and powerful Teutons had emerged from their German forests some few years before, when the cry swept through the bleak kingdoms of the north that the steel barrier of the empire was yielding at length. Less brave than the Goths, but more greedy of spoil and more fierce in victory, they had cut their way across Gaul and the Pyrenees, and formed a comfortable kingdom in Spain. Now, Genseric was leading them into the very granary of the empire, and they gathered their skins about them, and grasped

1 Victor says eighty thousand all told. Mr. Hodgkin does not think there were more than twenty thousand soldiers. 


\section{A SADDENED TERMINATION}

the odds and ends of arms and armour they had picked up in their march through civilised lands, and, with their wives and children, spread themselves over the rougher plains of Mauretania. Adventurous Goths and Spaniards had joined the host before it left Spain, and now the Moors and Getulians, as soon as they realised that this strange and fierce army of eighty thousand souls was rushing to the spoliation and destruction of the marble cities of the hated Romans, flocked to the bible-standards of the Arian savages. The chain of fortresses that had guarded the mountaingates of the provinces against the tribes of the desert had been almost abandoned during the intestine war, and tributary streams flowed down from every pass as the army swept along between the mountains and the sea. Soon they reached the broad roads that the Romans had constructed along the coast and the outlying towns. They poured themselves over the fields and orchards, leaving only a waste of blackened stubble and uprooted trees behind them. They swept down on the cities with a bitter scorn for their civilisation and a hatred of their Trinitarian religion and an insatiable thirst for gold. Bishops and priests hid the sacred vessels, and one savage 
would hold their mouths open with a stick while his fellows poured in vinegar, or salt-water, or filth, until they consented to reveal their treasures; then, perhaps, they would be loaded like mules with the booty their churches had provided, and goaded along, blinded with lime and bleeding with wounds. Here and there a stronger town resisted the invaders, and they gathered the corpses that lay thick on their path, and flung them to rot in thousands under the walls, until famine and pestilence forced the gates. Then came a more frightful carnage, and the flames of churches and palaces lighted the sated vultures to their feast. ${ }^{1}$

Towards the end of the year Genseric had reached the rich towns of Numidia, when the messengers of Boniface came to tell him that the war was over, and he might return to Spain. Before him lay two of the richest provinces of the empire, and behind him lay several hundred miles of blackened territory, where the famished beasts wandered in a dying frenzy, and the fugitive inhabitants trembled in the mountain

1 Such, at all events, is the story of the Christian writers Victor, Idatius, and Possidius. I have previously quoted Salvianus as to their chastity. 
caves, and the smoking ruins marked the sites of prosperous villages and opulent towns. $\mathrm{He}$ laughed at the idea. He had never intended either to return to Spain - that was understoodor to occupy the comparatively barren Mauretania. Boniface offered him a heavy ransom in the name of the empire, but a far greater treasure glittered before the eyes of his troops, and he himself had little inclination to be prince of Mauretania. He now knew the resistance he was likely to meet. His wild hordes probably contained no more than thirty or forty thousand effective and well-armed warriors. A timely and determined opposition could have flung a line of defence from the Atlas to the sea that his bands could not have passed. But the African subjects of the Roman empire had no more idea of patriotic resistance than the inhabitants of Italy. The corrupt and degenerate spirit of its closing years had made them incapable of lifting a spear. They looked helplessly to their professional soldiers and hired troops--who had been butchering each other in the interest of a wirepulling politician whilst Genseric was sweeping over Africa. They became the slaves of the fierce Teutons, or fed the pestilence or the vultures 
with their corpses, or fled to the mountains, or rang out their ghastly folly in their amphitheatres and circuses (so says Salvianus) whilst the cries of their dying soldiers and the guttural shouts of the ruthless savages mingled with their laughter. But they could not forge a spear or handle a scythe. And so Genseric knew he had only the organised troops of Boniface to meet, and, after a short truce, he resumed his bloody march. Boniface flung his troops in vain against the Vandal army. He lost the battle, and retreated to Hippo with the remnants of his forces.

It was about the end of May 430 when Genseric appeared at the walls of Hippo. Augustine had now entered upon his seventysixth year, and we can imagine the feelings with which he would look out from the besieged city. From the hill in its centre one could look over the greater part of his parœcia and a good deal of the Numidian province. He could see that the work of his laborious life had been destroyed in six months. In the general devastation the Arian soldiers had plundered and fired the Catholic churches with a peculiar zeal. From point to point on the horizon, where he had been wont to mark the growth of the Church, only columns of 
smoke now arose from the ruined towns of Numidia. Only Cirta, Hippo, and Carthage had successfully opposed the invaders; and these were closely besieged, and had little human hope of ultimate deliverance. Hippo occupied a fortunate position from a military point of view, as I have already described. Two broad rivers protected it on the north and south, and stout walls drawn from river to river defended its eastern and western boundaries. But in the distracted condition of the empire there seemed so little prospect of relief from beyond the seas that defeat could only be a question of time. To all human appearances the end of the African Church was in view; it was most certainly the end of Augustine's work that was written in lurid letters, for his dying eyes to read, over the face of the country. There were those who found a certain consolation in the belief that the end of the world was heralded in this devastation. The question of the end of the world had always been approached with hesitation and reserve by Augustine. He saw that the prophecies of the New Testament had not been fulfilled. The nations had not been converted to Christ (Arianism being as rank an error as polytheism), and certainly the 


\section{ST. AUGUSTINE AND HIS AGE}

Jews still held aloof. He could not, therefore, seek relief in the thought that his life-work was only tumbling to pieces in the general dissolution that God had decreed for the city of men.

Gibbon has been severely taken to task by Catholic writers for hinting that Augustine may have been troubled in his last days by the thought that the persecution of the Donatists had assisted the invasion by preparing a rebellious body at home. There is really no weighty evidence of an alliance of the Donatists with the invaders, nor does it seem likely that such an alliance would or could be formed in an appreciable degree. The Vandals wanted no Trinitarian allies; and there must have been few sincere Donatists left in 430 . In an earlier letter (ep. I 85) to Count Boniface Augustine speaks (in 417) of an Arian, or semiArian element amongst the Donatists, and says that some of them were disposed to fraternise with the Goths. It is very possible that some of these semi-Arian Donatists survived until $43^{\circ}$, and were admitted to comradeship with the wild Vandals. In any case, the number must have been small, and cannot have had the slightest influence on the issue. The question becomes more serious when we add the discontent of the 
pagans and Manicheans. As we saw, when Augustine put on the black tunic in $39^{2}$, the Catholics were in a pitiful minority. The vast majority of the population were pagans, Manicheans, or Donatists. It was chiefly by an unhappy appeal to secular force that Augustine had effected the change, and a good deal of illfeeling must have lingered amongst the people. Yet even here impartial reflection will scarcely find a serious source of disaffection to the empire. The Vandal smote down the pagan, the Manichean, and the Donatist as readily as he felled the orthodox Trinitarian. He had a narrow and ferocious zeal for the most cultured form of Christianity. At the most one can only think that the persecutions inspired by the Catholic bishops to Catholic emperors had been one additional element in the corroding forces that had eaten away the old Roman spirit, and left the inhabitants of the empire like flocks of sheep before the invaders.

It is not probable that Augustine was troubled with reflection on that question at all. The movements of the barbarians were guided by Providence, in his belief; and where the designs of Providence were inscrutable, he would trouble 


\section{ST. AUGUSTINE AND HIS AGE}

little about human considerations. Indeed, Augustine continued his work with a singular calmness-with what might be called indifference to the critical situation, except that the feeling was grounded on a deep religious faith. We are able to follow him in his last days because his pupil and biographer, Possidius, was in the beleaguered town with him. As the invasion advanced, the more sincere clergy were seized with a grave perplexity. The majority of their people could not take to horse like themselves, and they were torn between the stories of the Vandal treatment of priests and the spiritual interest of their flocks. Augustine's last letter is a reply (ep. 228) to a petition for advice on the subject from the bishop of Thiave. They must remain with the last of their people, was his inevitable answer. However, a number of bishops, including Possidius, had fled to Hippo, and remained there with Augustine when the Vandals closed round the walls. Hippo was a mile from the sea (so that the sea-front did not remain open, as Gibbon supposes), and was completely surrounded by Genseric's forces. It is hardly likely that in the city of Augustine the circus and amphitheatre continued their games 
during the siege, as Salvinnus declares of Carthage. But the church was open, and Augustine preached constantly to his people until illness prevented him. And, perhaps, if ever one is justified in quoting that well-worn adage of 'the ruling passion,' it is here. Whilst the Vandals thundered at the walls Augustine was absorbed in his great refutation of the latest reply of the Pelagian bishop of Eclanum, Julian. ${ }^{1}$

In the third month of the siege Augustine was seized with a fever. Possidius relates that, as he lay ill, a sick man was brought to him, and he was begged to lay hands on him and cure him. Augustine refused at first, pleasantly observing that if he had the power of healing the sick he would exert it to his own advantage. However, the man urged that he had been warned in a dream to approach Augustine, and he had too serious a view of such communications to resist further. He laid hands on the man, and the disorder was miraculously cured. It is one of the

1 Here Mr. Hodgkin makes a curious slip in his very estimable Italy and Her Invaders (vol. ii.). He says that during the siege Augustine was 'busily employed adding a "Confutation of the emperor Julian" to his vast library of books." It was the 'Unfinished work against Julian' (of Eclanum) that occupied him. $\mathrm{He}$ never troubled much about the emperor Julian's brilliant failure to galvanise into life the corpse of the old Roman religion. 
most remarkable features of Augustine's life that this is the only miracle he is recorded to have worked. Once more, I fear the Hipponenses were not a very grateful or appreciative people. Possidius does, it is true, vaguely refer to some cases of the expulsion of devils, but that could scarcely be accounted a miracle in the early centuries of the Christian era.

Ten days before his death Augustine bade farewell to his people, and withdrew into a chamber, where the penitential psalms, written large, hung from the walls by his bed-side. $\mathrm{He}$ begged his friends not to disturb him except when the physician came to see him or his food was brought. Here he died on the 28 th of August 430, in the seventy-sixth year of his age, ' sound in every member of his body, and retaining his sight and hearing to the end.' The strong will had sustained the slight frame through sixty years of untiring exertion, and left it with an integrity which few preserve. He left no will, says Possidius, for he had nothing to bequeathe, but he directed that his books and writings should be retained by his church.

The faith of his people in the value of his intercession was rewarded. After fourteen 
months the Vandals were compelled by famine to raise the siege, and most of the inhabitants escaped to Italy. But Boniface was again defeated, and the Vandals returned and set fire to Hippo, though it is recorded that they spared the church and library of Augustine. Genseric concluded a peace in 435 , consenting to leave Carthage to the empire, but he soon cast his treaty to the winds and subdued the whole of north-west Africa. During the century of Vandal rule and Arian persecution that followed the African Church was almost extinguished. In 534 the expulsion of the Vandals and the patronage of the eastern empire revived its fortune for a few years, but the country was weakly held, and only for a few miles from the coast; and the Moors and tribesmen prevented the steady restoration of its institutions. In 647 the African sun first flashed from the crescent of the advancing Arabs, and by the end of the seventh century the last relics of Roman civilisation and Christian worship were scornfully swept into their long-sealed tombs from Carthage to the Pillars of Hercules. And the only monument that remains in his native land of Augustine's great work is a strangely persistent memory of 'a great Christian,' in whose honour 
the Arabs hold a quaint celebration over the ruins of Hippo.

Yet in the world of thought and letters Augustine has left an enduring memorial of his great powers. With the advance of our knowledge of the vast theatre in which human life is enacted, and with the increasing penetration of humane feeling and ethical control into religious thought, even Catholic theology is departing more and more from Augustine's conception of the Gospel message. It may be that his distinctive opinions will eventually be abandoned by all but the historian or the pathologist of ideas. But, whatever judgment they pass on the convictions that inspired his actions and the results that followed them, men will not refuse their admiration to one who devoted his great ability so strenuously to the unselfish prosecution of a high ideal in a world of deep corruption. And the writer who can captivate a Calvin and a Boccaccio, a Newman and a Byron, has an immortality assured, whatever creeds or anticreeds prevail. 


\section{BIBLIOGRAPHY}

ThE life of St. Augustine is chiefly gathered from his works (for which I have generally used the Migne edition), especially the 'Confessions,' the 'Letters,' and the 'Retractations.' After these comes the 'Vita Beati Augustini' of his disciple, Possidius; and a certain amount of biographical and supplementary information is supplied by the chronicles of Idatius and Prosper, the 'De Schismate Donatistarum' of Optatus, the 'Historia Persecutionis Africanæ' of Victor of Vita, and the 'De Gubernatione Dei' of Salvianus. The story of his age is learned from : the letters of Jerome, Ambrose, and Q. A. Symmachus; the 'Res Gestæ' of Ammianus Marcellinus; the 'Vitæ Philosophorum' of Eunapius; the poems of Claudian, Prudentius, and Ausonius; the 'Saturnalia' of Macrobius; and the histories of the later Procopius. All these, except the lastnamed, are contemporary, or nearly contemporary writers. 
Amongst modern biographies of Augustine the chief are: Cardinal J. O. Von Rauscher's 'Augustinus' (facile princeps-a recent and comprehensive work); M. J. J. F. Poujoulat's 'Histoire de S. Augustin' ( I 852 ) ; C. Bindemann's 'Der Heilige Augustinus' (1 844); and the 'Saint Augustine' of an anonymous Irish priest (2nd ed. I 888 , a spirited but uncritical work, spoiled by the usual effort to make Augustine a modern Romanist). The 'St. Augustine' of A. Hatzfeld $(1898)$ is a vague and not wholly reliable sketch, and the 'St. Augustine' of Mr. C. H. Collette (I883) is a much less informed and equally interested excursus from the anti-Romanist side. Few others amongst the innumerable sketches are worth reading. The life in vol. xiii. of Tillemont's 'Mémoires,' which is chiefly followed by the Latin life of the Benedictines, is a model of laborious and reverent research.

Useful assistance in reconstructing the age, the world, and the thoughts of Augustine may be obtained from the following works: 'St. Augustin,' by L. Grandgeorge (a study of his Platonist ideas); 'Die Quellen Augustin's,' by C. Frick; 'Die Geistesentwickelung des H. Augustinus' of F. Woerter ; 'Saint Augustin' of 
H. A. Naville; 'Augustinische Studien' of $\mathrm{H}$. F. Reuter; 'La Philosophie de St. Augustin' of J. F. Nourisson ; 'Historia Critica Philosophiæ' of J. Brucker ; 'Mani' of C. Kessler ; 'Du Polythéisme Romain' of B. Constant; 'Histoire Critique de Manichée et du Manichéisme' of J. de Beausobre; 'Römische Mythologie' of $\mathrm{L}$. Preller; 'Commentatio Historica de Ævo Theodosiano' of P. Muller; 'Roman Society in the last Centuries of the Western Empire' of S. Dill (1 899); 'Italy and Her Invaders' of T. Hodgkin (1880); 'Le Christianisme aux trois Premiers Siècles' of E. de Pressensé ; 'Histoire de Civilisation' of F. Ozanam; 'Tableau de l'Éloquence Chrétienne' of A. Villemain; 'The Fall of Rome' of J. G. Sheppard ; 'L'Église et l'Empire Romain' of De Broglie; 'Histoire de la Déstruction du Paganisme' of A. Beugnot; ' Geschichte des Untergangs des Heidenthums' of V. Schultze ; 'La Fin du Paganisme,' 'Promenades Archéologiques,' and 'Roman Africa' of G. Boissier; 'L'Afrique au Cinquième Siècle' of $A$. Biéchy; 'Der Fall des Heidenthums' of H. G. Tzschirner; 'Heidenthum und Judenthum' of J. J. Döllinger; 'Untersuchungen über die Africanische Kirche' of A. Schwartze; 'Africa 


\section{ST. AUGUSTINE AND HIS AGE}

Christiana' of S. A. Morcelli; 'Roma Antica' of Nardini ; 'Pagan and Christian Rome' of R. A. Lanciani; 'Ancient Rome' of R. Burn ; 'Carthage,' 'Ruined Cities of Numidia,' and ' The Carthaginian Church' of N. Davis. I need not add Gibbon, and the magnificent 'Handbuch der Römischer Alterthümer' of Marquardt and Mommsen. 


\section{INDEX}

Abélard, 33, 37, 169.

Academics, the, 112, $132,156,158$. Actors, moral condition of, 28-9.

Adeodatus, $112,126,155,1_{56}, 165$, 188.

Adrumetum, the monks of, $3^{8} 3$, 406-7.

Ad Simplicianum, the, 339 .

Aesculapius, cult of, 23, 26, 90 .

Aetius, $415,416$.

Africa, Roman, 2-8, 23-32.

African Church, the, 189, 191, 197, $243 \mathrm{seq}$.

Agapæ, the, 76, 109-10, I 21 , 204-7.

Alaric, 268, 292.

Albicerius, 40.

Albina, 3 I I-I 5, 379 .

Albinus, 104.

Alypius, 57, 61, 1 16, 145, 1 51, 165, 1 79, 198, $213,219,273$.

Ambrose, St., 78, 93, 94, 97, I 19 9-22, $152-3,217,281,282$.

- influence of, on Augustine, $119-22$.

Ammianus Marcellinus, 37, 41, 70,

74, 94 .

Amphitheatre, the, 27, 77.

Animal suffering, Augustine on, 208.

Annona templorum, the, 89, 290.

Annotationes in Job, the, 324 .

Antony of Fussala, 1 98, 394-6.

Aphrodite, 26.

Apiarius, the affair of, 386-94.

Apuleius, 16.

Arabs, the, 2, 194, 429.

Arbitrator, Augustine as an, 226, 227.
Argobastes, $28 \mathrm{I}$.

Arians, Augustine and the, 410,411 , 414 .

Aristotle, Augustine's indebtedness

to, 133 .

- study of, 45 .

Asceticism, 52, 1०9.

398.

Astarte, $7,24,26$.

Astrology, 38-43, 63 .

Astronomy in Augustine, 64, 187 .

Athens, 14 .

Attalus, 268, 293, 294.

Augustinians, the, 180 .

Aurelius, bishop, 28, 1 89, 368, 375, 386,388 .

BAAL-H

Ballad against the Donatists, 203.

Baptism of Augustine, $17,36,165$.

Bath, the, $5,76,156$.

Baur on Augustine, 322, 344.

Bayle on Augustine, 215.

Beugnot, 283, 291, 294.

Birth of Augustine, 8.

Boissier (quoted), 3, 35, 80, 299.

Boniface, Pope, 381, 390, 391, 395, 396.

Boniface, the general, 4 I $3-17,420-2$, $424,429$.

Botrus, 245.

Breviary, the Roman, 341 .

Brucker on Augustine, 330.

Cacilian, 245, 246, 249.

Cælestis, temple of the, $24,26,287$. 


\section{$43^{6}$ ST. AUGUSTINE AND HIS AGE}

Calama, riot at, 291.

Calculo, the, ro.

Calvin and Augustine, 384 .

Canons of Sardica, the, $387,391$.

Captives, Augustine sells sacred vessels to liberate, 229.

Carthage, 22-32, 61 .

- councils of, $256,368,373$, $387,390$.

- great conference at, 269-74.

Cassian, 382, 383.

Cassiciacum, 154 .

Caterva, the, at Cæsarea, 389.

Catholics, origin of the name, 201.

Celestius, 245.

Christianity and the cultured pagans, $105,303-4$.

- in the fourth century, 7,19 , 48, 93-1 13 .

Chrysostom, St., 31, 78, 106.

Church, constitution of the, in the fourth century, 251 .

Church-life in the fourth century, $189,191-2,197,204,205,223$, 286, 3 I 4,336 .

Circuncellions, the, $253,265,275$.

Circus, the, $27,61,75,77,88$.

Cirta, synod of, 247.

City of God, the, 39, 304-1 1.

Claudianus, 84 .

Calestine, Pope, 396.

Cœlestius, 357-9, 364, 372, 382 .

Collette, Mr., 222.

Colonia, 4.

Communism in Augustine's seminary, $214,218,402$.

Competentes, the, 163 .

Confession in the fifth century, 223.

Confessions, the (quoted), 9, I I, 20, $33,35,45,57,59,97,130,179$, 215.

the, analysis of, I 68-7 1 .

Constantine, conversion of, 93 .

Contra Academicos, the, 40, 56, $5^{8}$, 158.

Contra Adimantum Manichaum, the, 328.

Contra adversarium Legis et Prophetarum, 330.

Contra Cresconium, the, 261 .
Contra duas epistolas Pelagianorum, the, 381 .

Contra epistolam Donati, the, 203, 256.

Contra epistolam Parmeniani, the, 261 .

Contra Faustum, the, 326, 328, 329.

Contra Judaos, the, 329 .

Contra Julianum, $38 \mathbf{I}$.

- (imperfectum), the, 427 .

Contra litteras Petiliani, the, 258 .

Contra Maximinum, the, 411 .

Contra mendacium, the, 335 .

Contra partem Donati, the, 258.

Contra Priscillianistas et Origenistas, the, 330.

Contra Secundinum Manichoum, the, 328.

Conversion of Augustine (quoted from Confessions), 145-52.

- significance of the, $1+2$.

Cresconius, $26 \mathrm{I}$.

Crispinus of Calama, 259.

Curiales, 4, 9 .

Cybele, cult of, 26, 89, I 10.

Cyprian, St., 252.

Damasus, 95, 97, 107, 109.

Davis, Mr. (quoted), 26.

Death of Augustine, 428 .

De Broglie (quoted), 80, 93, 98, $152,190$.

Debates of Augustine, the, 201, 212 , $230,257,389$.

Decuriones, 4 .

Demetrius, 316-18, 377 .

Descartes, anticipated by Augustine, 310.

De agone Christiano, the, 339.

De apto et pulchro, the, 60 .

De Baptismo, the, $26 \mathrm{r}$.

De beata vita, the, 159 .

De bono conjugali, the, 260, 33 I.

De bono viduitatis, the, 334 .

De catechizandis rudibus, the, $33^{8}$.

$D_{e}$ conjugiis adulterin is, the, 334 .

De consensu Evangelistarum, the, 326 .

De continentia, the, 331 .

De cura pro mortuis gerenda, the, $33 \mathrm{~S}$.

De diversis quastionibus octoginta-

tribus, the, 339.

De divinatione damonum, the, 339 . 
De doctrina christiana, the, 328 .

$D_{e}$ dono perseverantia, the, 55,383 .

De duabus animabus, the, 201 .

De fide et operibus, the, 339.

De fide et symbolo, the, 339.

De fide rerum, the, 339 .

De Genesi ad literam, the, 186.

De Genesi: contra Manichaos, the, I 86.

De Gratia Christi et Peccato Originali, the, 379 .

De haresibus, the, 329, 409.

De immor alitate anima, the, 164 .

De libero arbitrio, the, $173,207-9$.

De littera et spiritu, the, $3^{6} 3$.

De Magistro, the, 188.

De mendacio, the, 335 .

De meritis et remissione peccatorum, the, 362 .

De moribus Ecclesia, the, 174.

De moribus Manichaorum, the, 64, 174.

De musica, the, 187.

De natura boni, the, 328 .

De natura et gratia, the, 363 .

De nuptiis et concupiscentia, the, 335 , 381 .

De octo Dulcitii quastionibus, 339.

De opere monachorum, the, 335 .

De ordine, the, 161 .

De patientia, the, 339 .

De perfectione humana justitia, the, 364 .

De pradestinatione sanctorum, the, $3_{8} 8_{3}$.

De quantitate anima, the, 173.

De sancta virginitate, the, 331 .

De Trinitate, the, 336 .

De unico baptismo, the, 261 .

De utilitate credendi, the, I I 2, I 19 , 199.

De vera religione, the, $138,176,184$.

Dill, Mr. (quoted), I 5, 80, 95, 317 .

Diospolis, synod of, 366,368 .

Divination, $38-43,63$.

Divorce, Augustine's view of, 334 .

- in Roman law, $8 \mathrm{r}$.

Donatism and the Anglican Church, 277.

Donatists, the, 8, 201, 203, 243-77. and the Vandals, 268,424 .
Donatists, persecution of the, 253 , $255,258,263-8,275$.

violence of the, 210,250 , 254, 259, 265, 275 .

Donatus, 37, 250.

Dods, Mr. Marcus (quoted), 33, 140, 345 .

Education in the Roman world, 10-19, 37, 46 .

Emeritus of Cæsarea, 389 .

Enarratio in psalmos, the, $221,323$.

Enchiridion, the, 338.

End of the world, Augustine's view, 333,423 .

Endelechius, 88 .

Enneads, the, I 34 .

Epicureanism, 1 28, 129.

Episcopal courts, 226.

Erudition of Augustine, 132, 137, 322,344 .

Eucharist, Augustine on the, 327.

Eugenius, 281, 282.

Eulogius, 61 .

Evil, Augustine on the nature of, 1 $18,135,161,173,185,207$, $310,348,360$.

Evodius, 1 55, I 73, 179, 198, 207, 368.

Evolution of Augustine's ideas, $345 \cdot 50$.

Faith and reason, Augustine on, I 76, 200, 329, 347, 398 .

Fall of Rome, 78, 298-302.

- Augustine on the, 298, 304.

causes of the 300 .

Christianity and the, 299-302.

Fascius, incident of, 224 .

Faustinus of Potentina, 386,387 , 390-2.

Faustus of Mileve, $65,327,329$.

Felix, debate with, 230.

Felix of Aptunga, 249.

Fiscal system of Rome, 4 .

Flavianus, $83,100,281$.

Floralia, the, 7, 89, 110, 292.

Fortunatus, I 75, 20 I.

Fortunius, debate with, 257. 


\section{$43^{8}$ ST. AUGUSTINE AND HIS AGE}

Free will, Augustine on, 173, 185, $207,208,3^{8} 4$.

Friendship, in the Confessions, 59.

Genesis, Augustine on, 186, 310 , 325.

Genseric, 32, 415, 418, 420, 422, 429.

Gibbon (quoted), 30, 95, 152,153 , 276, 282, 291, 299, 302, 305, $316,384,424,426$.

\section{Gildo, 253.}

Gothic invasion, the, 268, 292, 294.

Grace, Augustine's doctrine of, 208, $359-61,383$.

Grammar, Augustine's work on, 164 .

- study of, 12-13,37.

Grammaticus, the, 12 .

Gratian, 1 5, 57, 87, 95-7, 280.

Greek language, study of the, 13,14 .

Hamilton, Sir W., on Augustine, 322.

Harnack (quoted), $48,50$.

Hatzfeld (quoted), 35, 190, 417 .

Health of Augustine, 215.

Hebrew, study of, 14.

Hefele (quoted), $387,391$.

Heraclian, 267, 269, 294, 315, 319.

Heraclius, Augustine's successorelect, $404-6,411$.

Heros, 366,372 .

Hilarion, St., 42.

Hippo, 190, 193-5.

siege of, $422,426,427,429$.

Hodgkin, Mr. (quoted), 4, 32, 41 5 , $418,427$.

Honorius, 29, 375, 376 . decrees of, $266-9,275,286$, 290, 294, 296.

Hortensius, the, 45,46 , 158 .

Hypatia, 38 .

IDEAs of Augustine, comprehensively considered, $342-50$.

Infant baptism, Augustine on, 207, 349, 362 .

Innocent, Pope, 42, 368, 370, 372.

Isis, cult of, 92, 110.
Jerome, St., 22, 31 , 37, 42, 70, 102 , $103,104,105,172,174,183$, $191,235-42,283,353,356,364$, 365 .

- corresponds with Augustine, $235-42$.

Jerusalem, synod of, 364-5.

Julian of Eclanum, $380-2,427$.

Julian, the emperor, 94,427 .

Juliana, 316-18, 378 .

Justina, $121,152,153$.

Kingsley, Mr. 46, 181, $183,217$.

Lestitis, the, 204-7.

Lastidianus, 155 .

Lazarus, 366, 372.

Legacies, Augustine's trouble over, $219,220$.

Leibnitz on Augustine, 322.

Leporius, the monk, 407.

Letters of Augustine, 23 1-42.

Libyans, the, 2.

Licentius, 1 16, 1 $55,156,160,179$.

Literator, the, 10 .

Literatus, the, 12.

Lucilla, 246, 249.

Lupercalia, the, 89 .

Luxury of the Romans, 70-73, 78,82 . Lying, Augustine on, 335 .

Macrobius, $70,74,8 \mathbf{1}, 82$.

Marlaura, 16, 289 .

Majorinus, 250.

Mani, 50.

Manichean sacrament, the, 409 .

Manicheans, morality of the, 64 , 92, 175, 202, 408 .

publicly examined, 408,409 .

Manicheeism, 48, 49-56, 62-6, 92, 1 34, I 35, 172-6, 185, 201 .

Manlius Theodorus, 131 .

Manumission of slaves, 225.

Marcellinus, 269, 271-5, 303, 31920, 362 .

Marculus, the heretic-saint, 265 (note).

Marinus, 3 I 9.

Marriage, Augustine's view of, 33 I -5 .

Martyrology, the Roman, 265.

Martyrs, cult of, $185,246,398$. 
Mary, Augustine's attitude towards, $341-2$.

Mass, the, $223,327$.

Mathematics, study of, 37 .

Mattarii, the, 53.

Maximinus, letter to, 203.

the Arian, 410.

Megalius of Calama, $211,274$.

Melania, 311-15, 379 .

Memoriæ martyrum, the, 204.

Mensurius of Carthage, 245.

Milan, 116.

Mileve, synod of, 368 .

Military service and Christianity, 301.

Miracle, Augustine's sole, 42\%.

Miracles at Hippo, 399-401.

- Augustine on, 176-8, 399-401.

Mistress of Augustine, the, 33, 124, 126.

Mithraism, 48, 49, 91-2, I 72, 326.

Monastery of Augustine, the, 178 , 198.

Monasticism in the west, $180-3$, $33^{6-7}$.

Monica, St., 8, 17, 20, 36, 56, 68, $121,125,126,155,156,158,167$. - - death of, 167 .

Morality of Christians at Carthage, 31, 34, 42; at Rome, 42, 106-I1. - of pagans, $31,32,79-85$.

- of the African bishops, 245-50. - of the Manichees, 44, 92, 175 , 202, 408 .

Mosheim on Augustine, 344.

Mozley on Augustine, 344.

Municipal life in the fourth century, $4,5,9,12$.

Municipium, 3 .

Mythology, Roman, go.

Nebridius, 43, 6I, $116,156,179$, $184,187$.

Nectarius, 291.

Neo-Platonism, 48, 49, 105, I 33, 141.

Neo-Platonists, influence of the, on Augustine, 132, 134-8, 163 .

Nourisson (quoted), $63,132,164$, $168,208,343,3^{8} 3$.
Olympus, 265, 266, 290, 292.

Optatus of Mileve, $244,246$.

of Thamugade, 253.

Ordination of Augustine, 1 92, 211.

Origin of the soul, views of Jerome and Augustine, 242.

Original sin, Augustine on, 335, $349,360,364$.

Orosius, $305,354,364,365,367$.

Ostia, Augustine at, 166.

Paganism, 7, 1 8, 1 9, 24-7, 49, 87101, 278-97, 327 .

fall of, 93-101, 172, 278-97.

Papal claims not recognised in Africa, 251, 256, 274, 369, 37 I, 374, 386-8, 390-4, 395-6.

Pascentius, debate with, 231.

Patricius, 8, 17, 20, 22.

Paula, 101, 109.

Paulinus of Pella, 35.

$235,353,356,377$.

Pelagianism, 208, 354, 358-61, 369, $37^{8}, 380-2$.

Pelagius, $3^{18}, 35^{2}, 354-8,364-8$, $373,377,379,3^{82}$.

- works of, $35^{6}$.

Persecution, Augustine's view of, $255,258,260-3,276,285,289$.

Petilian, 140, $258,273,276$.

Petrarch on Augustine, $221,323$.

Philanthropic work of Augustine, $224,227,228$.

Philosophy, study of, in the fourth century, 15,46 .

Pinianus, 3 1 I-1 $5,379$.

Plato, Augustine's debt to, 1 32, 133 , 1 $37,163,179,185,346$.

- Augustine on, 1 38, I 39, 179, 185,$309 ; 346$.

- study of, $47,132$.

Plotinus, Augustine's indebtedness to, $133-6,137$.

Polygamy, Augustine's view of, $332-4$.

Pontitianus, 144 .

Pope, use of the word in the fourth century, 252. 


\section{ST. AUGUSTINE AND HIS AGE}

Possidius, 57, 190, 196, 211 , 2 I 2, 214, 259, 291, 368, 426, 427, 428.

Poujoulat (quoted), 49, 1 54, 232, 276, 332.

Poverty of Augustine's clergy, 218 , $402 \cdot 3$.

Practical ability lacking in Augustine, 217.

Prætextatus, $\delta \circ, \delta_{3}, 100$.

Prayer for the dead, 167,338 .

Preacher, Augustine as a, $22 \mathrm{I}$.

Pressensé, M. de, 243, 250.

Priapus, cult of, 29, 90 .

Proba Faltonia, 316-18.

Prosper, 26.

Psalmus contra partem Donati, the, 203.

Publicola, the letter to, 234.

Punic language, the, 12, 14, 222.

- religion, the, 7, 24, 26.

l'urgatory, in Augustine, 338 .

Purpurius, 247, 249.

Pythagorean ideas in Augustine, 161,187 .

2uastiones Evangeliorum, the 326 .

Rations, public, 6,75 .

Rauscher, Cardinal Von (quoted), $40,165,378,388$.

Relics, cult of, $153,336,398$.

Retractations, the, 339-40. $2+2$.

Rhetoric, study of, 14-16, 37, I1 4 .

Roman clergy, morality of the, 106-9.

- see, references to, $25 \mathrm{I}, 256$, $274, \quad 368-70,371,373,374$, $3^{86-8}, 390-4,395-6$.

Romanianus, 22, 56, 57 , I 16, 127 , I $76,179,185,186$.

Rome, 69 seg.

Rosenbaum, 26, 85 .

Rousseau, Confessions of, 1 26, 169 .

Rufinus, 354, 357 .

Rule of St. Augustine, the, 180, 397.

Rusticus, I 55 .

Rutilins Numantinus, 302 .
Saints, Augustine's view of cult of the, 342 .

Salvianus, 3, 7, 27, 30, 32, 34, 69, 316.

Sanctuary, the law of, 224.

Saturn, cult of, $24,27$.

Saturnalia, the, of Macrobius, $8 \mathbf{1}, 82$.

Saturnalia, the, 7, 89, 110, 292.

Scandals in Augustine's seminary, I 98,2 I 4, 2 1 8, 401, 409.

Scepticism of Augustine, $112,140$.

Schools, the Roman, 10-15, 18, 37, $46,60,67$, I I 4 .

Schultze (quoted), 7, 95, 283.

Scripture, study of, $47,48,122,132$, I $57,322,326$.

Secundus of Tigisis, 247, 249.

Seminary of Augustine, the, 1 99, 213.

Semi-Pelagianism, 382-4.

Sermons of Augustine, 28, 31, 199, 206-7, 209, 220, 287.

Shorthand in the Roman world, 157 .

Simplicianus, 143.

Sixtus, Pope, $367,376,377$.

Slavery, Augustine's view of, 225 .

Soliloquies, the, 46, I 6 I.

Souk-Arras, 1 .

Speculum Scripturce Sacroe, the, 327.

Spurious Augustinian literature, 165, 341.

Stephen, St., relics of, 398 .

Stilicho, 265, 268, 284, 290.

Stoicism, 128 .

influence of, $71,81,105$.

Style of Augustine, 162 .

Symmachus, 22, 70, 76, 83, 97, 100,

I 5 .

Synesius, 189, 217.

Suffecte, riot at, 288 .

TABLE, discipline at, 214- 6 .

Tanit, $24,26$.

- priests of, 25 .

Teaching of Augustine, 343 .

Telemachus, monk, 110.

Thagaste, I, 3, 8, 16, 19, 56, 176 .

Theatre, the, 28 .

Theodosian code, the, 37 .

Theodosius, 94, 279, 283, 284, 302. 


\section{INDEX}

Trigetius, $116,155,156,160$.

URBAN US of Sicca, $386,390,391$.

VALENS, $4 \mathrm{r}$.

Valentinian $\mathrm{I} ., 18,4 \mathrm{r}, 94$. - II., 94, 97, 28 o.

Valerius, bishop, 190, 196, 212.

Vandals, the, 32, 416, 418 seq.

Verecundus, $154,156$.

Victorinus, $131,143$.

Victory, statue of, $96-9,281$.

Vincentius, the Rogatian, 33, 262.

Vindicianus, 43, 6I.
Virginity, Augustine on, 331, 332, 334 .

Volusianus, 303 .

Woman, Augustine's attitude towards, $178,183,222,325,333$, 335 .

Works of Augustine, number of, $158,164,229,321$ seq.

Zosimus, Pope, 372, 373, 374, 375, $376,380,381,387,388,390$. 291.

Printed by T. and A. Constable, (late) Printers to Her Majesty at the Edinburgh University Press 

F R O M

Messrs. DUCKWORTH $\mathscr{G}^{\circ}$ CO.'S

\section{A T A L O G U E}

\section{$M C C A B E$, JOSEPH.}

PETER ABÉLARD. By JOSEPH McCABE,' Author of 'Saint Augustine and his Age.' Large crown 8vo. 6s. net.

Daily Telegraph.-'A singularly well-written, conscientious and philosophic study. . ' There are few so intensely alive, so vividly human, so palpitating with the ordinary impulses of a complex human character.'

Globe. - At last we have something like an adequate account of this famous medieval thinker. A satisfactory study of that very attractive personality.'

Manchester Guardian. - A clear and well-written book in which the materials are deftly handled and the remarkable figure of his subject is portrayed with eninent sym. pathy, fairness, and good sense.'

Spectator.- We give a cordial welcome to Mr. McCabe. The work is learned and readable, and as there is practically nothing on Abélard in the English language it is for the English reader a real contribution to the ecclesiastical history of the Middle Ages.'

SIR LESLIE STEPHEN'S Important Work, in Three Volumes.

\section{THE ENGLISH UTILITARIANS}

Demy 8vo. 30s. net.

VOLUME 1.-JEREMY BENTHAM.

I. Political Conditions. II. The Industrial Spirit. III. Social Problems. IV. Philosophy. V. Bentham's Life. VI. Bentham's Doctrine.

VOLUME 11.-JAMES MILL.

I. James Mill. II. Reform Movements. III. Political Theory. IV. Malthus.

V. Ricardo. VI. Economic Heretics. VII. Psychology. VIII. Religion. VOLUME III. -JOHN STUART MILL.

I. John Stuart Mill's Life. II. Mill's Logic. III. Political Economy. IV. Politics and Ethics. V. Historical Method. VI. Philosophy.

For fuller particulars as to the contents and scope of the book please apply to your bookseller for special prospictus.

STUDIES OF A BIOGRAPHER. By Sir Leslie STEPhen, K.C.B. Vols. I. and II. Large crown 8vo. Second Impression. Buckram, gilt top, I2s.

STUDIES OF A BIOGRAPHER. Vols. III. and IV. Just ready. Uniform with Vols I. and II.

$$
\text { HEADLEY,F. W. }
$$

PROBLEMS OF EVOLUTION. By F. W. HeAdley, Assistant Master at Haileybury College. With 14 Illustrations. Demy 8vo. 8s. net.

Literature.- An interesting study by one who is not only an accomplished biologist and naturalist, but has also thought much on questions of human progress and degeneration.'

\section{MANTZIUS, KARL.}

\section{DRAMATIC ART AND ACTORS, in Ancient and Modern} Times. By Karl MaNTzius. Translated by Louise von Cossel. With an Introduction by William ARCHer. Three Vols. Large Demy 8vo.

VOL. I. From the Earliest Times. Vol. Il. Down to the Time of Shakespeare. Vol. III. From Shakespeare's Tine to the Present Day. 
THE THEATRE; its Development in France and England, and a History of its Greek and Latin Origins. By Charles HASTINGS. With an Introductory Letter from Victorien Sardou. Authorised Translation by Frances A. Welby. Demy 8vo. 8s. net.

OWEN, J. A., and BOULGER, PROFESSOR.

THE COUNTRY MONTH BY MONTH. BY J. A. OWEN (Collaborator in all the Work signed 'A Son of the Marshes') and Professor G. S. Boulger. New Edition, with Notes by the late LORD Lilford: In one volume. Demy 8 vo. $500 \mathrm{pp}$. 6s. net.

STEPHEN, H. L.

STATE TRIALS: POLITICAL AND SOCIAL.

SECOND SERIES. Selected and Edited by II. L. STEPHEN. With Two Photogravures. Two volumes. Fcap. 8vo. 5s. net.

Contents-Vul. I. The Earl of Essex-Captain Lee-John Perry-Green and Others-Count Coningsmark-Beau Fielding.

Vot. II. Annesley-Carter-Macdaniell-Barnard-Byron.

Uniform with the First Serics of 'State Trials.'

STATE TRIALS: POLITICAL AND SOCIAL. FIRST SERIES. Selected and Edited by H. L. STEPhen. With Two Photo. gravures. Two vols. Second Impression. Fcap. 8vo, art vellum, gilt top. 5s. net.

Contents-Vol. I. Sir Walter Raleigh-Charles I. - The Regicides-Colonel Turner and Others-The Suffolk Witches-Alice Lisle.

VoL. II. Lord Russell-The Earl of Warwick-Spencer Cowper and Others-Samuel Goodere and Others.

\section{HUTCHINSON, T.}

LYRICAL BALLADS by WILLIAM WORDSWORTH and S. T. COLERIDGE, 1798. Edited with certain poems of 1798 and an Introduction and Notes by ThOMAS HuTCHINSON, of Trinity College, Dublin, Editor of the Clarendon Press 'Wordsworth,' etc. Fcap. 8vo. 3s. 6d. net. Uniform with 'State Trials.'

$$
\text { POLLOCK, SIR FREDERICK, BART: }
$$

SPINOZA'S LIFE AND PHILOSOPHY. By Sir FREDERICK Pollock, Bart. New edition, revised throughout. Demy 8 vo. 8s. net.

CONTENTS :-Introduction-The Life of Spinoza-Spinoza's Correspondence-Idea and Sources of Spinoza's Philosophy. Part I. Judaism and NeoplatonismPart I1. Descartes-The Doctrine of Method-The Nature of Things-Body and Mind-The Nature of Man-The Burden of Man-The Deliverance of ManThe Citizen and the State-Spinoza and Theology-Spinoza and Modern Thought -Appendix.

A thenau".- 'Sir Frederick Pollock has revised his excellent "Spinoza: His Life and Philosophy." In all essentials the book remains as it was-one of the very best monographs on a philosopher and his philosophy which exist in the language. The writing is as good as the thinking, and both are excellent.'

\section{HALE WHITE, W.}

ETHIC. Translated from the Latin of BeNedict DE SPINOZA by W. Hale White; translation revised by Amelia Hu'tchison Stirling, M.A.(Edin.). Third Edition. Corrected. Demy 8vo. 7s. $6 \mathrm{~d}$.

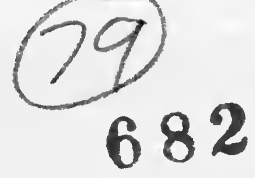






\section{PLEAse do nOt Remove}

CARDS OR SLIPS FROM THIS POCKET

\section{UNIVERSITY OF TORONTO LIBRARY}


